IRACEMA SOARES DE SOUSA

\title{
TEMPO LIVRE COM LAZER DO TRABALHADOR E A PROMESSA DE FELICIDADE
}


IRACEMA SOARES DE SOUSA

\section{TEMPO LIVRE COM LAZER DO TRABALHADOR E A PROMESSA DE FELICIDADE}

Tese apresentada como requisito parcial à obtenção do grau de Doutor na Área de Educação, Estado e Sociedade, do Curso de Pós Graduação - Doutorado em Educação, da Faculdade de Educação, da Universidade de São Paulo.

Orientadora: $\operatorname{Prof}^{\mathrm{a}} \operatorname{Dr}^{\mathrm{a}}$. Maria de Lourdes Manzini Covre. 
IRACEMA SOARES DE SOUSA

\title{
TEMPO LIVRE COM LAZER DO TRABALHADOR E A PROMESSA DE FELICIDADE
}

\begin{abstract}
Tese aprovada como requisito parcial à obtenção do grau de Doutor na Área de Educação, Estado e Sociedade, do Curso de Pós Graduação - Doutorado em Educação, da Faculdade de Educação, da Universidade de São Paulo
\end{abstract}

Orientadora: $\quad \operatorname{Prof}^{\mathrm{a}} \operatorname{Dr}^{\mathrm{a}}$. Maria de Lourdes Manzini Covre Faculdade de Educação da USP

Prof $^{\mathrm{a}}$ Dr $^{\mathrm{a}}$. Bernardete Wrudlevski Aued

Centro de Filosofia e Ciências Humanas da UFSC

Prof $^{a}$ Dr $^{\mathrm{a}}$. Carmen Sylvia Vidigal de Moraes

Faculdade de Educação da USP

Prof $^{\circ}$ Dr. Lino Castellani Filho

Departamento Estudos do Lazer/Faculdade Educação Física da UNICAMP

Prof $^{\circ}$ Dr. Marcos Ferreira Santos

Faculdade de Educação da USP

Prof $^{\circ}$ Dr. Ricardo Luiz Coltro Antunes

Instituto de Filosofia e Ciências Sociais da UNICAMP

Prof $^{\text {a }}$ Dr $^{\mathrm{a}}$. Sandra Maria Zákia Lian Sousa

Faculdade de Educação da USP

São Paulo, 5 novembro de 2002 


\section{AGRADECIMENTOS}

Ao concluir esta pesquisa agradeço a todas as pessoas que participaram de alguma maneira na realização deste estudo. Seja no âmbito teórico, seja no suporte afetivo. Agradeço especialmente ao empenho e paciência da orientação de Maria de Lourdes Manzini Covre. Estendo este agradecimento aos membros da banca no exame de qualificação: Carmen Sylvia Vidigal de Moraes, Lino Castellani Filho e Ricardo Coltro Antunes.

Aos sujeitos trabalhadores que me deram as informações solicitadas em todo o processo de realização desta pesquisa. Ao Serviço Social da Indústria (SESI) de Santa Catarina, nas pessoas de seus coordenadores de ginástica que facilitaram a entrada em campo na empresa, locus desta investigação.

E a essas pessoas, cada uma à sua maneira, me deram apoio especial em diferentes momentos do processo de construção desta pesquisa: Bernardete Wrublevski Aued, Clarissa Biscaia, Dr. Cláudio Fernando Werlang, Edna Maciel Fiod, Fátima Leitão, Iara Regina Damiani, Jucirema Quinteiro, Juliana Sousa, Maurício Roberto da Silva , Silvia Amaral e a Vera Fontes.

À minha família, em especial, minha filha Caroline por sempre compreender a minha ausência. À meu pai (in memorian), a minha mãe e irmãos, pois mesmo distantes, sabia que poderia contar com o apoio deles. 


\section{RESUMO}

Esta pesquisa apreende relações e contradições entre trabalho e lazer. Apresenta, nas condições atuais do trabalho assalariado, alguns fatores que estão expressando, na realidade historicamente configurada de uma indústria metal-mecânica, da cidade de Jaraguá do Sul, Estado de Santa Catarina, Brasil, limites e possibilidades para a existência de um tempo livre com lazer na vida de trabalhadores. A escolha dessa empresa para locus investigativo se deu porque ela possui uma base produtiva com tecnologia avançada e adota ginástica na empresa em seu expediente interno de trabalho. Fazem parte também da investigação um grupo de trabalhadores de uma das suas fábricas. As informações foram levantadas por meio da aplicação de 118 questionários; 120 entrevistas realizadas no chão da fábrica; como também importantes observações diretas, dentro da fábrica e fora dela. Dedicamos especial atenção ao que ocorre nos sábados e domingos, quando procuramos perceber as práticas de lazer fora da fábrica. Além disso, utilizamos documentos disponibilizados pelos diretores da fábrica com os quais mantivemos conversas, bem como com chefes de seção, operários e pessoas da cidade. O interesse por este estudo, e o emprego da conexão trabalho e lazer, justifica-se na medida em que existe uma opinião geral afirmando ser a base produtiva desenvolvida tecnologicamente o que promove lazer, bem como a presença de uma exercitação corporal dentro do horário de trabalho; aliamos a esses motivos o desconhecimento de pesquisas a terem contemplados essa problemática a partir de análises de dados empíricos. Neste sentido percebemos, a partir dos dados coletados, que a ginástica na empresa evidencia o corpo que produz e o corpo que brinca Todavia, constatamos que esta prática se configura como uma tecnologia organizadora do trabalho ao garantir produtividade com a restauração do equilíbrio e descanso do corpo, embora se realize com a presença do elemento lúdico. A base teórica a sustentar a análise contempla aspectos que procuram desvelar as mudanças recentes no processo de trabalho. A reestruturação produtiva engendra a ginástica na empresa e expressa a adequação de formas toyotistas ao processo industrializante no Brasil. A rigor, a assimilação desse modelo realiza-se, nessa empresa, de maneira híbrida e ocorre desde a década de setenta do século XX. Na vida fora do âmbito do trabalho das pessoas do grupo estudado constata a ausência do corpo que brinca. Nessas condições conclui que falta um tempo aos trabalhadores para si mesmos, um tempo a ser usado para exercitarem lazer. Constatamos ainda que existe uma contradição no processo de organização do trabalho, pois este inclui a ginástica na empresa evidenciando o corpo que brinca, ainda que este esteja fora dela. Vimos dessa maneira que o processo de organização no qual estão inseridos estes trabalhadores limita a existência de um tempo livre com lazer em suas vidas, sendo que o tempo cronometrado do trabalho comanda toda a existência concreta dessas pessoas, dentro e fora da fábrica; o tempo livre com lazer e não com desemprego, pode acenar como uma promessa de felicidade, possível de realizar, embora, ainda distante de uma realização concreta. 


\begin{abstract}
This research detects relations and contradictions between labor and leisure. It points out some factors, in the present conditions of paid labor, that are showing the limits and possibilities for the existence of free time with leisure in the life of the workers in the historically established reality of a metal-mechanics industry located in the town of Jaraguá do Sul, State of Santa Catarina, Brazil. This $\mathrm{XX}$ company was chosen as the locus for investigation because it had a production base with advanced technology and has adopted gymnastics in the company during its internal work period. One group of workers in one of its factories is also part of this investigation. The data was gathered by means of 118 questionnaires and 120 interviews held on the factory floor, in addition to some important direct observations, within and outside the factory. We have devoted special attention to what occurs on Saturdays and Sundays, when we seek to perceive the leisure practiced outside the factory. Furthermore, we utilize documents that were made available by the factory directors, with whom we have conversed on several occasions, as well as section heads, workers and other people in the town. The interest in this study concerning the utilization of the labor-leisure connection, is justified inasmuch as there exists a general opinion that technologically developed basis of production, along with the presence of bodily exercise during the working hours, promotes leisure, and that up to now there has been no known research on this problem based on analyses of empirical data. In this way we perceive, from the data that was collected that gymnastics in the company gives evidence of the body that produces and the body that plays. However, we found that this practice serves as a work organization technology, which guarantees productivity by restoring the equilibrium and rest of the body. The theoretical basis supporting the analysis considers aspects that provide a clearer understanding of recent changes that have taken place in labor process. Production restructuring engenders gymnastics in the company and expresses the adaptation of the toyotism forms to the industrializing process in Brazil. Actually, the assimilation of the model in that company is carried out in a hybrid manner and has been taking place since the 1970s. In the life of the people in the group that was investigated when they were away from the work environment, we found the absence of the body that plays. In these conditions, the workers have no time for themselves, time to be used for leisure. Furthermore, we found that a contradiction in the labor organization process, since it includes gymnastics in the company and shows the body that plays, even though the body is absent or the worker is outside his body. In this way we could see that the organization process in which these workers are inserted limits the existence of free time with leisure in their lives, and that the clocked time of their factory commands the entire concrete existence of these people, both inside and outside the factory. Free time with leisure but without unemployment constitutes a promise of happiness, which is possible, although it still has no concrete existence.
\end{abstract}




\section{SUMÁRIO}

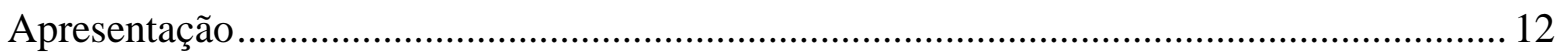

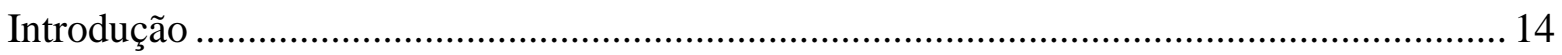

\section{A Industrialização na Cidade de Jaraguá do Sul e sua Grandeza}

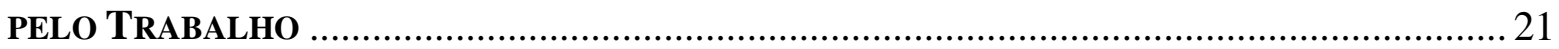

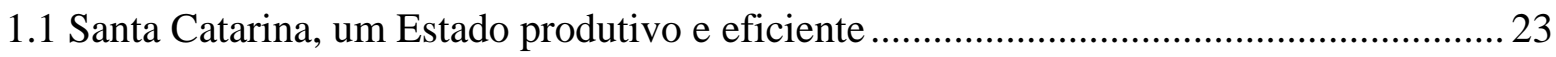

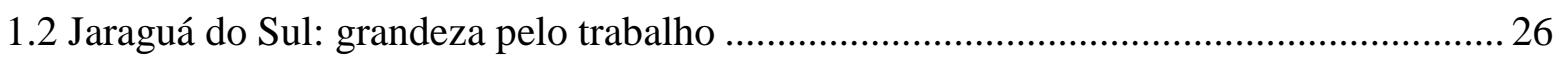

1.2.1 Retrocedendo no tempo... colonização e industrialização.................................... 36

1.3 A empresa destacada: trabalho, trabalho e trabalho...................................................... 45

1.3.1 Trabalho, tecnologia avançada e reestruturação produtiva dos anos setenta ...... 51

1.4 A Cultura da Empresa e o processo de organização do trabalho ...................................... 55

1.4.1 Sobre o modelo da organização interna do trabalho .......................................... 60

2 Ginástica na EMPResa: uma Tecnologia Organizadora do Trabalho ............. 69

2.1 Grupo de trabalhadores e o tipo de atividade desenvolvida na Fábrica X...................... 70

2.2 A Ginástica na Empresa: um produto do SESI e a sua relação com o trabalho .............. 76

2.3 A Ginástica na Empresa e o pressuposto do corpo biológico ......................................81

2.4 A Ginástica na Empresa: uma tecnologia organizadora do trabalho ............................. 83

2.5 A evidência do corpo na tecnologia organizadora do trabalho:

produtividade, cansaço, dor e prazer ……............................................................... 98

2.5.1 A tecnologia no corpo que produz e que também brinca .................................... 104

2.5.2 O Corpo que brinca no tempo de trabalho...................................................... 111

3 O Lazer dos Trabalhadores e o Lazer na Cidade de Jaraguá do Sul ................ 118

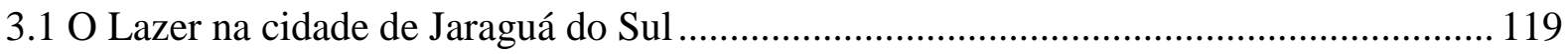

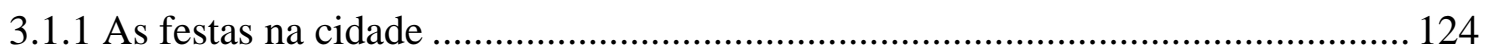

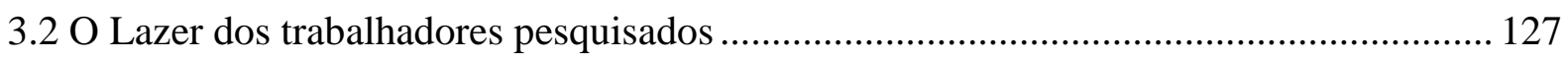

3.2.1 O caráter social do lazer, uma necessidade humana........................................ 137

3.3 Atividades de trabalho e lazer, uma separação inevitável ............................................. 138

3.4 A variabilidade do lazer segundo a percepção dos trabalhadores pesquisados ............... 149 


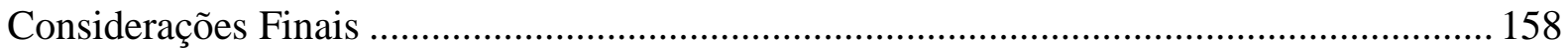

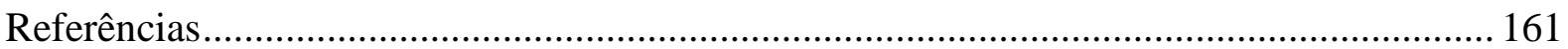

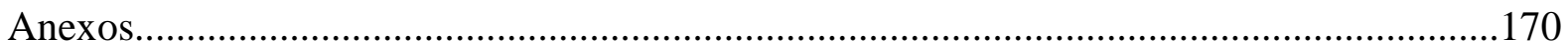




\section{LISTA DE FIGURAS}

1. Localização do Estado de Santa Catarina e município de Jaraguá do Sul......................... 23

2. Comparativo renda per capta - município, Estado, país .....................................................2 25

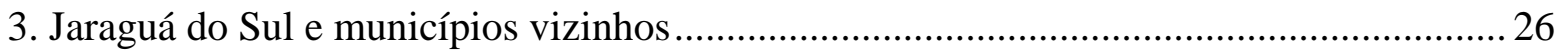

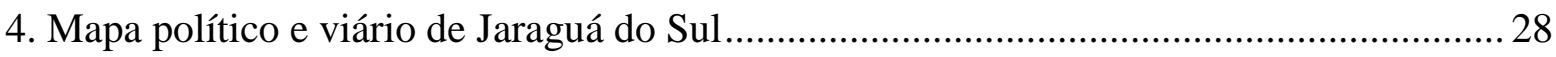

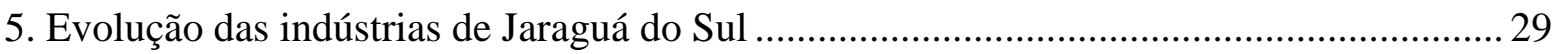

6. Evolução do comércio em Jaraguá do Sul .......................................................................... 31

7. Evolução do setor de serviços em Jaraguá do Sul ............................................................. 31

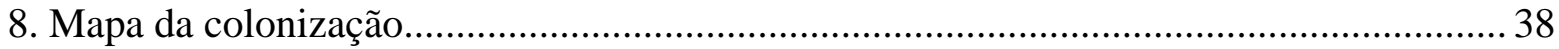

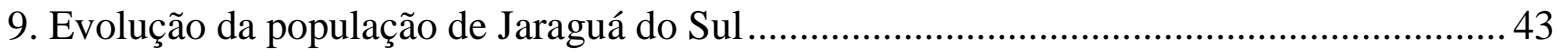

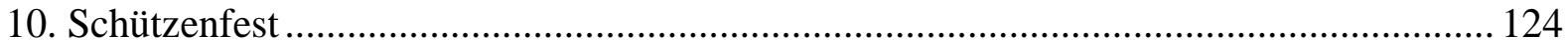

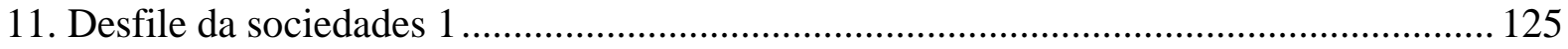

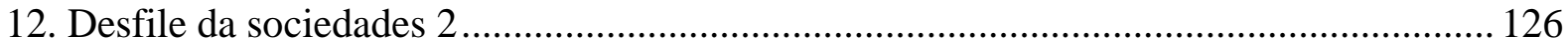

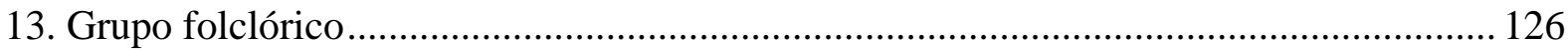




\section{LISTA DE TABELAS}

1. Evolução do produto interno bruto do Brasil, 1970/1999 …............................................. 30

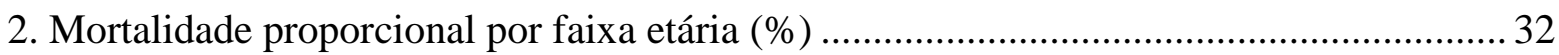

3. Taxa específica de mortalidade (100.000 habitantes - habitante de Jaraguá do Sul) ........ 33

4. Casos confirmados de doenças evitáveis por imunização (unidades) ............................... 33

5. Saneamento básico (\% da população urbana servida) .................................................... 34

6. Indicadores de condições de vida bloco habitantes, 1970/1980/1991 …........................... 34

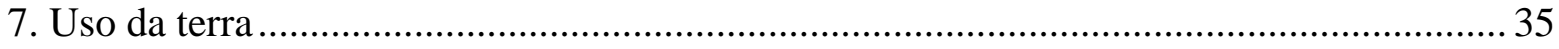

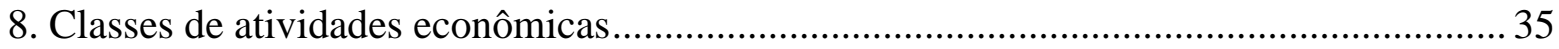

9. População recenseada no Brasil e em Santa Catarina 1940/2000.................................... 43

10. Número de motores produzidos e número de empregados entre 1961/1965 .................. 48

11.Número de motores produzidos e número de empregados entre 1966/1975 _.................. 48

12. Número de motores produzidos e número de empregados entre 1976/1986.................. 49

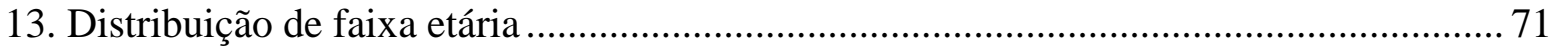

14. População segundo sexo, zona urbana e zona rural 1940/1996 ..................................... 72

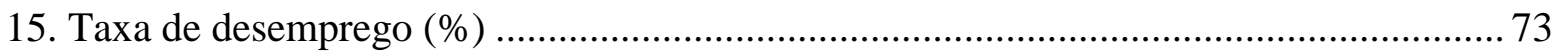

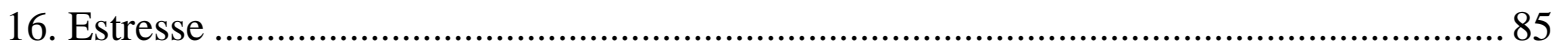

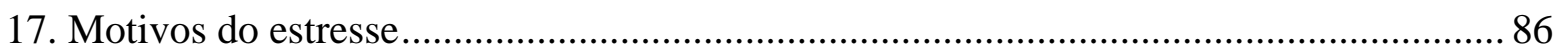

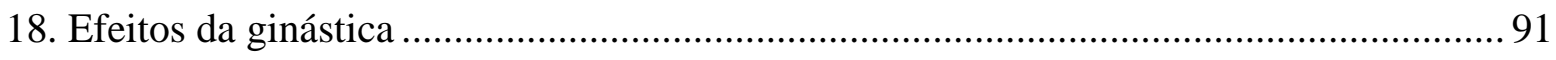

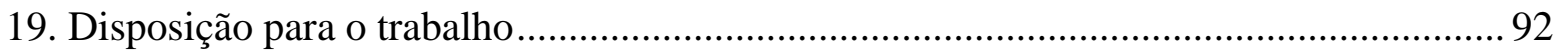

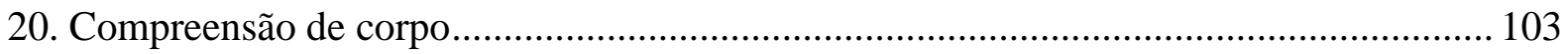

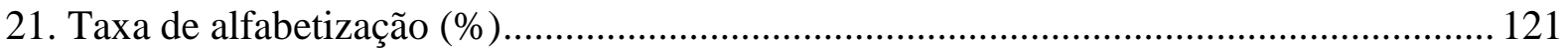

22. Dificuldades para a realização de atividades de lazer.................................................... 129

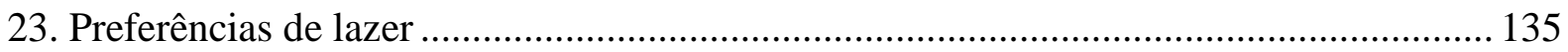

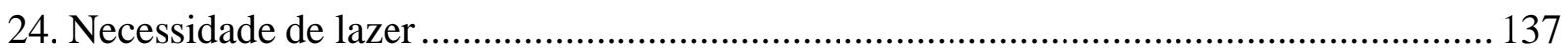

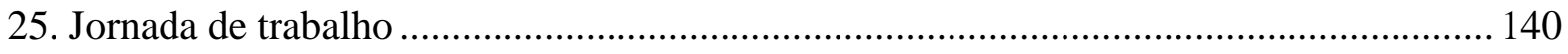

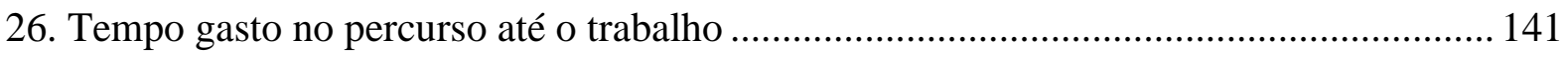

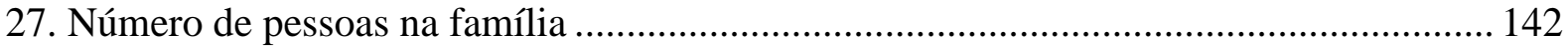

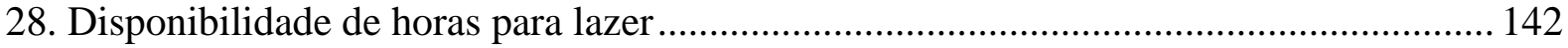

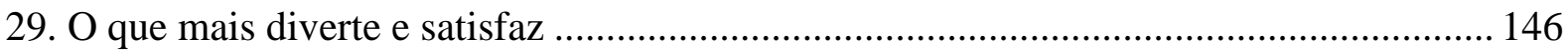




\section{LISTA DE ANEXOS}

1. Entrevista com o Gerente da Fábrica X (setembro de 2000)

2. Entrevista com o coordenador Estadual do Programa Ginástica na Empresa do SESI no Estado de Santa Catarina (Florianópolis, junho de 2000)

3. Entrevista com a primeira coordenadora do Programa Ginástica na Empresa do SESI, em Jaraguá do Sul (setembro de 2000)

4. Entrevista com a segunda coordenadora do Programa Ginástica na Empresa do SESI, em Jaraguá do Sul (junho de 2001)

5. Entrevista com o gerente de lazer de Jaraguá do Sul

6. Entrevista com um trabalhador da empresa selecionada para a pesquisa

7. Manual do colaborador

8. Calendário de eventos 2001

9. Questionário

10. Roteiro de entrevista 


\section{APRESENTAÇÃO}

Nesta pesquisa, buscamos conhecer e analisar o que acontece no processo interno de trabalho de uma fábrica e sua influência na relação entre trabalho e lazer. Estudamos por dentro do mundo do trabalho e do não trabalho relações que apresentam contradições entre esses mundos, porém orientando a análise para questões particulares que dizem respeito a limites e/ou possibilidades de um tempo livre com lazer na vida de trabalhadores.

As relações aqui consideradas entre trabalho, tempo livre e lazer não são lineares e são estabelecidas a partir de articulações entre a vida dos trabalhadores pesquisados no trabalho e fora dele. Não consideramos os mundos do trabalho e do não trabalho como diametralmente opostos, mas unidos dialeticamente.

A investigação se realiza numa empresa do ramo industrial metal-mecânico, localizada na cidade de Jaraguá do Sul, Estado de Santa Catarina, Brasil. Ela possui base técnica desenvolvida, adota o Programa Ginástica na Empresa, do SESI (Serviço Social da Indústria) e o desenvolve durante a jornada de trabalho. Uma das fábricas dessa empresa, aqui denominada Fábrica X, bem como um grupo de trabalhadores dessa mesma, serviram de locus para esta pesquisa.

Esta exposição está composta por três capítulos. O primeiro trata do contexto histórico em que se deu o processo de industrialização do Estado de Santa Catarina. Nele analisamos as condições do processo de instalação do trabalho assalariado e enfatizamos, particularmente, a história da cidade de Jaraguá do Sul, unida à da indústria do ramo metalmecânico, produtora de motores elétricos. Analisamos o modelo do processo de trabalho vinculado à cultura da empresa, a qual está consubstanciada na valorização de tecnologias avançadas e no ser humano.

No segundo capítulo, analisamos a presença da ginástica na empresa durante o expediente de trabalho como uma inovação tecnológica no chão da fábrica pesquisada. $\mathrm{O}$ conceito de Covre $(1985,1990)$ de tecnologia organizatória do trabalho nos serviu para caracterizar essa ginástica como uma novíssima tecnologia, a qual se subsidia em fatores também subjetivos e se utiliza do corpo que produz evidenciando o corpo que também brinca 
Na seqüência, apresentamos, no terceiro capítulo, a análise sobre os elementos que expressam limites e ao mesmo tempo possibilidades para existir, de fato, um tempo livre com lazer na vida dos trabalhadores pesquisados. Essa análise originou-se a partir da relação entre as condições do processo de trabalho da fábrica escolhida e as condições de vida dos trabalhadores fora dela. Orientamos as argumentações considerando como esses trabalhadores concebem e realizam atividades de lazer, contrastando as opções que a cidade oferece com o que eles efetivamente praticam.

Por último, procuramos, nas considerações finais, realizar uma síntese geral tendo em vista os fatores que dificultam a existência concreta de tempo livre com lazer para os trabalhadores pesquisados. 


\section{INTRODUÇÃO}

O lazer, o tempo livre, o ócio e o trabalho ganharam, principalmente no final do século XX, uma extraordinária repercussão em debates, tanto nos meios acadêmicos quanto nos meios de comunicação.

Num contexto conturbado que dispensa o consumo de massa e produz como nunca a exclusão social (Chauí, 1999), há uma significativa quantidade de análises sobre essa temática. Autores como Aznar (1995), De Masi (1994), Schaff (1993), Offe (1989) e Gorz (1987), dentre outros, discutem que a implantação de inovações tecnológicas é causadora do desemprego e juntamente com Habermas (1987) desconsideram o trabalho como categoria chave de explicação da realidade e de organizador da vida social. Já Dumazedier (1994) afirma que estamos numa revolução cultural do tempo livre. O grupo Krisis, em seu manifesto contra o trabalho (1999) desaprova em todas as dimensões as relações advindas deste mundo, o do trabalho.

O contexto histórico que acolhia esse debate era o que a maioria dos autores denominam de terceira revolução industrial; sendo ela fruto da dinâmica do processo de desenvolvimento tecnológico pela criação do computador, da robótica, das máquinas com comando numérico computadorizado, enfim, da microeletrônica. Alguns autores chegaram mesmo a proclamar a chegada da sociedade de tempo livre; outros afirmavam categoricamente que o trabalho não era a categoria central da organização da vida social e humana e que o lazer era quem poderia orientar a vida de todos. Esses avanços supunham, também, novas formas de gestão e de organização da produção (DIEESE, 1996).

Desses avanços tecnológicos, os desdobramentos mais evidentes foram a estimulação da chamada reestruturação produtiva, que aliavam a essas tecnologias a dimensão econômico-política, resultando nos discursos sobre a globalização da economia e o neoliberalismo. Compondo ainda a configuração dessa reestruturação produtiva, há a gestação de um novo modelo de organização da produção no Japão. Tudo isso aconteceu logo no início da recessão mundial (década de 50), e eclodiu no início da década de 70 do século passado. É nesse momento, chamado de globalização da economia, que as exportações nacionais ganham ênfase. A abertura dos mercados, a partir dos ideais neoliberais, implementada pelo primeiro 
presidente eleito da Nova República, em 1989, viabilizam essas condições. Nesse sentido, cria-se a idéia de que para as empresas conquistarem esses mercados e não serem atingidas pela recessão econômica em processo no mundo, há de se alterar a organização do trabalho, até porque, como falavam a maioria dos autores, havia uma mudança abissal em curso, a situação no Brasil era de necessidade de entrar no mercado mundial e competir com outras empresas.

Várias medidas de organização do processo de trabalho são adotadas, no Japão, na Itália, e divulgadas como capazes de incrementar a melhoria da produtividade com qualidade nas empresas. O modelo, então chamado de toyotismo, é centrado em flexibilizações de vários tipos e busca produtividade com baixo custo. A produção deve ser controlada pelos próprios trabalhadores; eles podem analisar e avaliar, entre eles, os problemas que podem surgir na seção, pensar soluções e encaminhá-las, contanto que essas idéias sirvam para melhorar a produtividade.

Nesse ambiente de trabalho, em época recente, no Japão, havia mortes súbitas, as pessoas morriam na linha de montagem das indústrias, daí surgiram medidas para diminuir o grau de tensão, e, dentre outras providências foi usado a ginástica como forma de, pela via do corpo, controlar os níveis do estresse, que eram evidentes.

No bojo dessa variada discussão, optamos por mergulhar numa realidade que, apesar de desconhecida para nós, haveria de apontar elementos vivos que pudessem permear a discussão sob o ponto de vista das transformações oriundas do mundo do trabalho; porém, partindo de uma realidade social concreta.

Dessa situação surgem muitas questões, mas nos chama atenção a indagação sobre como, no contexto da chamada reestruturação produtiva, justificada pela implementação de inovações tecnológicas na base técnica da produção, o trabalhador assalariado poderia ter um tempo livre com lazer em sua vida e não desemprego. O que poderia acontecer em nossa realidade?

Assim, buscamos conhecer, nas condições atuais de trabalho assalariado, fatores que poderiam representar limites e possibilidades para a existência de um tempo livre com lazer na vida de trabalhadores, numa realidade com as características o mais próximo possível 
das advindas da reestruturação produtiva, ou seja, numa empresa que implementasse tecnologias avançadas tecnicamente em sua base de produção e adotasse um programa de ginástica em seu expediente de trabalho. Recorremos, para tanto, à relação trabalho e lazer com o propósito de apreender possíveis contradições nessa relação, as quais poderiam representar as dificuldades (os limites e/ou possibilidades) para a obtenção desse tempo livre do trabalho para praticar lazer. Entendemos que as contradições ao serem explicitadas têm mais chances de serem resolvidas.

O que particulariza a problemática e se traduz como a questão central desta pesquisa é a apreensão, na relação entre trabalho e lazer, de fatores que podem expressar limites e possibilidades para a efetivação de um tempo livre com lazer na vida de trabalhadores assalariados fora do trabalho, numa realidade em que o corpo se apresenta de forma explícita em uma dimensão pouco conhecida, a do corpo que brinca, no interior do processo de trabalho, pela prática da ginástica na empresa.

Acompanhando outras questões que estão subordinadas à central, procuramos saber: até que ponto as relações de trabalho podem facilitar ou não a conjugação do tempo livre e lazer? Trabalho e lazer são dimensões de um mesmo processo? Qual o elemento unificador e/ou desagregador dessa relação? Os avanços tecnológicos estão de alguma forma alterando a jornada de trabalho num maior tempo livre? Uma exercitação corporal orientada e fazendo parte do processo interno de trabalho dentro de uma fábrica serve para quê? Será que a ginástica na empresa contribui na promoção de uma maior produtividade? Como ela contempla/considera a existência de um corpo que brinca e por quê? Essa prática altera a compreensão do trabalhador sobre seu próprio corpo? Será que o lazer é visto e praticado pelo trabalhador como uma necessidade? O que eles fazem para implementar e criar as condições para a sua prática? Que tipo de lazer eles preferem e realizam fora da fábrica? Que sentidos os trabalhadores da empresa pesquisada conferem ao lazer?

Procuramos, também, averiguar os sentidos da presença de uma exercitação corporal orientada, a ginástica na empresa, no processo de trabalho, a partir das intenções da empresa e de como essa ginástica repercute para os trabalhadores, procurando identificar a que serve, enfim, essa exercitação corporal; como eles lidam com o corpo que brinca no meio do expediente de uma fábrica e observar ainda, o grau de influência das relações de trabalho e 
como elas se estabelecem ou se estabeleceram na vida dessas pessoas e o porquê dessa influência.

Em relação ao mundo fora do expediente de trabalho buscamos averiguar como eles concebem lazer e o que realizam de fato como atividades de lazer, observando, assim, elementos vivos que possam dar uma resposta com base concreta para o problema. Outra consideração é verificar se há contradição entre a criação de uma necessidade que é construída socialmente (histórica, datada) e a sua não satisfação. Assim, a explicitação desse impedimento fortaleceria a luta pela sua extinção. Em vista disso, não partimos nem do mundo do trabalho nem do não- trabalho, mas da relação entre ambos.

Entendemos que a necessidade de tempo livre com lazer não se limita unicamente à vida dos trabalhadores; temos claro que é uma necessidade universal, de todos os seres humanos. Entretanto, para atender a um recorte de pesquisa, uma vez que não conseguiríamos abarcar a totalidade, delimitamos a coleta de dados empíricos a um grupo de trabalhadores de uma empresa do ramo metal-mecânico, bem sucedida e situada na cidade de Jaraguá do Sul que fica ao norte do Estado de Santa Catarina, Brasil. Assim, para chegarmos a uma de suas fábricas, primeiro escolhemos a empresa. Essa escolha se deu a partir de dois critérios definidos a priori: o primeiro foi que a empresa dispusesse de tecnologias avançadas em seu processo produtivo e o segundo foi que ela adotasse o programa ginástica na empresa. Ela vem sobressaindo na implementação dos avanços tecnológicos na base técnica, e inclui, a ginástica na empresa no expediente de trabalho já há algum tempo.

Especificamente sobre o tempo livre e o lazer do trabalhador, dispomos de poucas pesquisas, principalmente contando com análises que se originem de dados empíricos e que se sustentem na relação entre trabalho e lazer.

É nesse campo minado de controvérsias, divergências e diferentes interesses que o problema desta pesquisa emerge. A falta de unanimidade na conceituação do lazer e do trabalho pela maioria dos autores, que tratam do tema, produz um entendimento de que essa problemática não é tão simples como aparenta à primeira vista.

Assim, para fundamentar as observações sobre a vida habitual desses trabalhadores utilizamos Lefebvre (1984), que nos apresenta com bastante clareza a riqueza 
da vida habitual e a necessidade que os seres humanos têm para expressar a sua subjetivação. Sugere que as pessoas ao serem dificultadas ou impedidas de realizar uma auto-expressão são empurradas para fora do trabalho. Afirma também que "[...] é na vida cotidiana onde se situa o núcleo racional, o centro real da práxis" (p 44) e considera igualmente que o cotidiano é manipulado através da organização controlada e minuciosa do emprego do tempo. Segundo ele há distinção entre as horas (do dia, da semana, do mês, do ano) em três categorias: o tempo obrigado (o do trabalho profissional), o tempo livre (o do ócio, lazer) e o tempo forçado (ligado a atividades gasto em transporte, gestões, formalidades) Esse autor classifica esses tempos em relação ao trabalho e apresenta uma crítica sobre a não consideração da vida cotidiana (leia-se - reprodução social) como definidora da vida humana. Assim, concebemos, junto com o autor que o lazer se realiza num tempo livre do trabalho.

Cunha (1987) nos fornece subsídios teóricos para compreendermos as separações do tempo como uma produção histórica, a qual nem sempre foi da forma como se apresenta hoje. Já Lefebvre (1984) explica sob o ponto de vista do cotidiano, uma divisão de tempo situada habitualmente em nossa vida.

Heller (1991) alerta para a diferença entre o trabalho em geral e o trabalho particular, distinguindo o labour como as circunstâncias concretas do processo de trabalho concreto para o (a) trabalhador (a), e o work como processo de trabalho concreto no modo como ele se realiza como trabalho para a sociedade em seu conjunto. Esse processo apresenta dois aspectos: um como execução de um trabalho (parte orgânica da vida cotidiana) e outro como atividade de trabalho (uma objetivação diretamente genérica). Nessa pesquisa, fundamentamos o trabalho na concepção de Heller (1991), levando em conta aquele trabalho que é executado habitualmente, cotidianamente.

Considerando com Lefebvre (1984) que, o centro real da práxis acontece na vida habitual e, como estamos carecendo de elementos vivos para dar um novo sentido à busca e efetivação de um tempo livre com lazer, aportamos nesse contexto de explicações procurando os elementos teóricos principais para dar conta da realidade social que acolhe a temática do tempo livre e lazer.

Entendemos que a conquista de um tempo livre com lazer se reveste hoje em dia, apesar de já ser uma bandeira antiga da luta dos trabalhadores, de uma conotação mais crítica 
no sentido de irmos em busca das causas que dificultam essa conquista, desocultando a base, o que fundamenta a problemática, para assim obtermos, no mínimo, o conhecimento dos fatores que determinam os limites para a sua efetivação, pois embora o tempo livre com lazer possa ser conquistado pelo desenvolvimento das condições no processo da vida material, vem sendo entendido como uma conseqüência fatalista.

Nesta pesquisa são consideradas atividades de lazer aquelas que, de algum modo, contribuem para o desenvolvimento integral de potencialidades humanas em qualquer dimensão, porém tendo clara a sua finalidade e em quais relações são estabelecidas. Utilizamos a compreensão de atividade humana expressa por Heller (1991) em sua vinculação com o trabalho.

A complexidade deste assunto tem levado a uma produção intelectual que às vezes se configura em pontos de vista opostos e até mesmo antagônicos. Para alguns autores, lazer para o trabalhador significa a possibilidade de crescimento pessoal. Para outros, contudo, o lazer não passa de uma extensão do trabalho, momento em que o trabalhador, fora da fábrica, repõe energias para mais uma jornada de trabalho, caracterizando-se como atividade que acontece num tempo residual de trabalho. Nesta pesquisa, entendemos que tempo de trabalho e tempo livre constituem dimensões de um mesmo processo em que um não pode existir sem o outro, pelo menos, nesta sociedade, e que tempo livre em si não existe, porém tempo livre do trabalho sim.

A ginástica na empresa foi pouco analisada no meio acadêmico e optamos por entendê-la a partir dos pressupostos elaborados por Covre (1996, p. 203), como técnica social organizatória, ou seja, um desdobramento do processo de produção da vida contemporânea. Enfim, como uma tecnologia organizadora do trabalho.

Quanto aos pressupostos vinculados à área de educação física realizamos uma análise crítica, por eles explicarem apenas uma parte dessa exercitação corporal, não explicitando a sua dimensão subjetiva. Não temos ainda uma sistematização teórica que dê conta do envolvimento de uma exercitação corporal acontecendo no expediente de trabalho e que, de uma forma subjetiva, atinge a organização interna do processo de trabalho produtivo. 
Concebemos o tempo livre com lazer do trabalhador como uma necessidade histórica do mundo contemporâneo, advinda das condições em que se realiza a produção da riqueza material.

Por fim, importa-nos, especificamente, compreender que elementos sociais estão historicamente amadurecendo nas entranhas do mundo do trabalho, e que podem gerar ou possibilitar transformações que, embora parecendo embrionárias, expressem uma outra forma de organização societal, mas que ainda podem não repercutir na consciência social do trabalhador. 


\section{A INDUSTRIALIZAÇÃO NA CIDADE DE JARAGUÁ DO SUL E SUA GRANDEZA PELO TRABALHO}

Neste capítulo tratamos do contexto histórico em que se deu o processo de industrialização do Estado de Santa Catarina, analisando e expondo condições do processo de instalação do trabalho assalariado. Enfatizamos, mais particularmente, a história da cidade de Jaraguá do Sul conjugada à da indústria do ramo metal-mecânico, produtora de motores elétricos, selecionada para locus desta pesquisa.

Partimos de elementos compositores, da intitulada cultura da empresa ${ }^{1}$ para conhecer o que estava ocorrendo de fato no chão de uma das fábricas do parque industrial selecionado e ampliar a nossa percepção no que se refere ao modelo e constituição do processo interno de organização do trabalho. A orientação desse modelo, segundo informações e observações realizadas, segue especialmente dois princípios ${ }^{2}$ : valorização da implementação de tecnologias avançadas, tanto dos produtos que a empresa fabrica quanto da base técnica dessa produção, e a valorização do ser humano.

Esse processo caracteriza-se, tal como sugere Antunes (1995), como um modelo híbrido de organização de trabalho, sendo a cultura da empresa e a ginástica ${ }^{3}$ como uma tecnologia organizadora (Covre, 1983, 1990) do trabalho, os elementos que impulsionam e lhes imprimem distinção.

Segundo depoimentos, tanto dos diretores quanto da maioria dos trabalhadores pesquisados, tudo é feito para que os empregados se sintam bem no chão da Fábrica. Averiguamos esse propósito por meio de de observações realizadas em uma das Fábricas do

\footnotetext{
${ }^{1}$ Cultura da Empresa é todo tipo de ação que se fundamenta em princípios, valores, lemas. Tudo o que faz parte da subjetividade humana é denominado, nessa empresa, por Cultura da Empresa.

${ }^{2}$ Segundo Ternes (1997, p. 195), ela baseia sua missão em princípios que constituem a cultura da empresa, adotando permanentemente: valorização do homem; qualidade autêntica; assistência técnica confiável; clientes e fornecedores tratados com justiça e respeito; reinvestimento dos lucros; tecnologia de ponta e produtos atualizados (normas e padrões); independência tecnológica em produtos e serviços; vender soluções em vez de produtos; acionista igual a sócio.

${ }^{3}$ Dado o seu caráter inovador, desenvolvemos especificamente uma análise dessa tecnologia no segundo capítulo.
} 
complexo industrial da empresa, doravante denominada Fábrica X, bem como pelo material ${ }^{4}$ disponibilizado por alguns de seus diretores.

A cidade de Jaraguá do Sul, acolhedora da referida empresa, apresenta um desempenho diferenciado em termos de qualidade de vida na região sul do Brasil. Esse espaço fabril e citadino parece contrariar, no entanto, algumas formulações que analisam a industrialização como a contrapartida necessária da miséria, implicando interfaces da Fábrica, cidade e trabalho, com bairros miseráveis, trabalho infantil crescente e violência social, dentre outras mazelas. Porém, não foi essa situação que vimos na cidade e empresa analisadas.

Em relação aos trabalhadores, observamos que mesmo os que não trabalham numa das diversas Fábricas dessa empresa 'sonham' fazê-lo um dia, e os que fazem parte da Fábrica $\mathrm{X}$ aderem maciçamente ao modelo de organização de trabalho existente. Foi no decorrer da pesquisa de campo que percebemos essa adesão e por essa circunstância vimos que apenas identificar esse modelo não bastaria, era preciso explicar esse amálgama.

Qual o segredo dessa empresa e lugar? Desvendar esse segredo, sem dúvida, poderia resultar num relevante trabalho para muitas outras empresas e cidades que freqüentemente são ameaçadas por problemas sociais, crises e processos falimentares. Contudo, nossa pretensão foi mais modesta, o que nos levou a delimitar o universo investigado em como está configurado o processo de trabalho no chão da Fábrica $\mathrm{X}$, ressaltando, no entanto, o seu envolvimento no entorno social.

Por outro lado, esse processo interno de trabalho apresenta indicadores que transcendem ao escopo de uma proposta que só atinge internamente a fábrica, já que existem traços presentes da cultura da empresa no espaço citadino de Jaraguá do Sul. Por isso, neste primeiro capítulo, buscando equacionar essa imbricação, adentramos a história de Santa Catarina inserida na de Jaraguá do Sul que, por sua vez, conjuga-se à da empresa selecionada.

Analisamos suas diretrizes, os desdobramentos na cidade e como eles se alicerçam e se interconectam, e os dispusemos nos seguintes itens: Santa Catarina, um Estado produtivo e eficiente; Jaraguá do Sul: Grandeza pelo trabalho, tendo como subitem: Retrocedendo no

\footnotetext{
${ }^{4}$ Livros sobre a empresa, folders, jornais e outros tipos de documentos.
} 
tempo... a colonização e a industrialização; A empresa destacada: trabalho, trabalho, trabalho, tendo como subitem: Trabalho, tecnologia avançada e a reestruturação produtiva dos anos setenta. Nesse item já tratamos da história da empresa conjugada à da cidade, evidenciando os primeiros traços do processo interno de trabalho. O último item: A cultura da empresa e o processo de organização interno do trabalho, trata das relações entre as características particulares no tocante a essa cultura da empresa, os modelos de organização interno de trabalho e o que de fato acontece no chão da fábrica.

\subsection{Santa Catarina, um Estado Produtivo e Eficiente}

O Estado de Santa Catarina ${ }^{5}$ faz parte da região sul do Brasil e tem uma área de 95.442,9 $\mathrm{Km}^{2}$ (DIEESE, 1999), equivalente a 1,12\% do território nacional. Em termos geográficos, a Região Sul limita-se com o Uruguai, a Argentina, o Paraguai e a Bolívia.

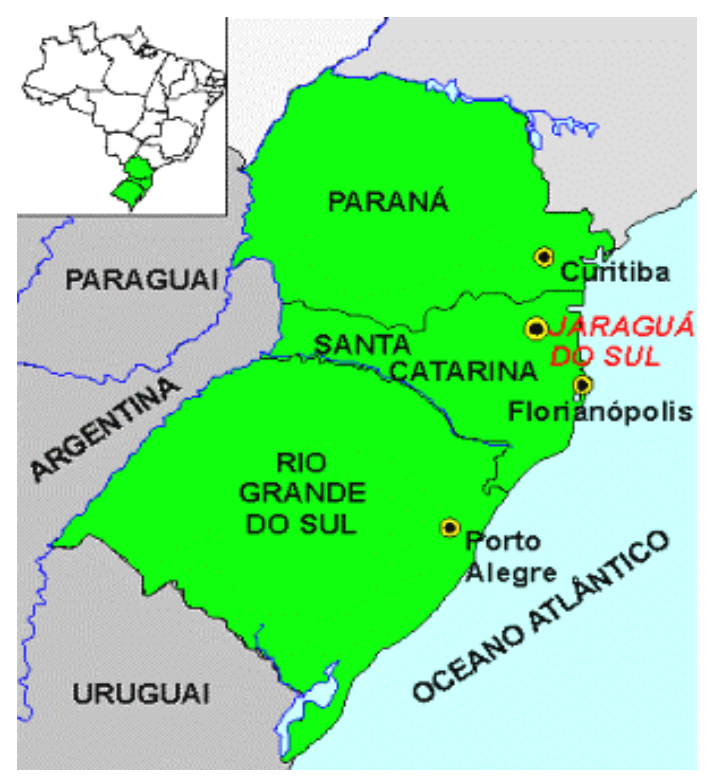

FIGURA 1 - Localização do Estado de Santa Catarina e Município de Jaraguá do sul na Região Sul do Brasil.

\footnotetext{
${ }^{5} \mathrm{O}$ nome Santa Catarina foi concebido pelo navegador Sebastião Caboto em 1526 e referia-se inicialmente à ilha onde hoje se situa a capital Florianópolis.
} 
Em Santa Catarina existem 293 Municípios (DIEESE, 1999). As cidades que mais se destacam são: Florianópolis (capital do Estado), Joinville, Blumenau, Itajaí, Jaraguá do Sul, Laguna, Criciúma, Lajes, Tubarão, Imbituba e Chapecó.

A história de Santa Catarina é constituída de um vasto amálgama de acontecimentos diversos, e embora permeada de particularidades, não deixa de refletir a história da própria humanidade. Dentre essas particularidades, chama especial atenção o sucesso de certas indústrias que crescem em meio à crise de atividade industrial, ao desaparecimento de muitos postos de trabalho e às conseqüências do acirramento da competitividade internacional.

Atualmente, o ramo ${ }^{6}$ produtivo que mais se desenvolve nesse Estado é o metalmecânico. Tal ramo, ao contrário de muitos outros, é responsável por uma curva ascendente de criação de postos de trabalho, apesar da crise estrutural de desemprego (DIEESE, 1996). O padrão estadual da indústria metal-mecânica tem também se diferenciado em relação às de outras regiões do Brasil. Ela exibe a mesma curva ascendente de crescimento econômico e de afirmação comercial no mercado nacional e internacional.

Segundo dados do DIEESE (1996, p.111), o setor metal-mecânico no Estado de Santa Catarina

[...] possui cerca de 4.300 empresas, representando $20 \%$ da transformação industrial e gerando algo em torno de 60.000 empregos, isto é, $16 \%$ dos empregos com carteira assinada existente no Estado. A região norte do Estado possui as maiores empresas do setor como Embraco, Fundição Tupy, Multibrás, Wetzel, Weg, Carrocerias Nielson e a Kolbach.

A maioria dessas empresas são micro e pequenas e estão espalhadas por todo o Estado. Das 3.008 indústrias metalúrgicas catarinenses, 2.859 são micros (até 10 empregados), 119 pequenas (de 11 a 100 empregados), 23 médias (de 101 a 500 empregados) e, apenas 7 são grandes (acima de 500 empregados). Das mecânicas, que totalizam 1.326

6 A produção catarinense é diversificada. O carvão mineral foi um dos ramos econômicos mais importantes do Estado. É o único Estado que produz fluorita da qual se extrai o flúor. A agropecuária também tem se destacado, produz milho, arroz e maçã. As indústrias de transformação local desenvolvem vários ramos, a indústria alimentícia é um ícone industrial; outras também se destacam como a do vestuário, da cerâmica, da química, do papel, de móveis, plásticos, cristais, fundição e metalmecânico. 
indústrias, 1.120 são micros, 167 pequenas, 35 médias e 4 são grandes indústrias (DIEESE, 1996, p.111).

A empresa por nós destacada faz parte das sete grandes indústrias do ramo metalúrgico. Essa indústria e cidade fundem-se e formam uma unidade, pois, na medida em que a empresa se projeta nacional e internacionalmente, a cidade a acompanha. A empresa destaca-se no cenário regional e também no País, como podemos constatar pelos dados de renda per capita expostos na figura abaixo:

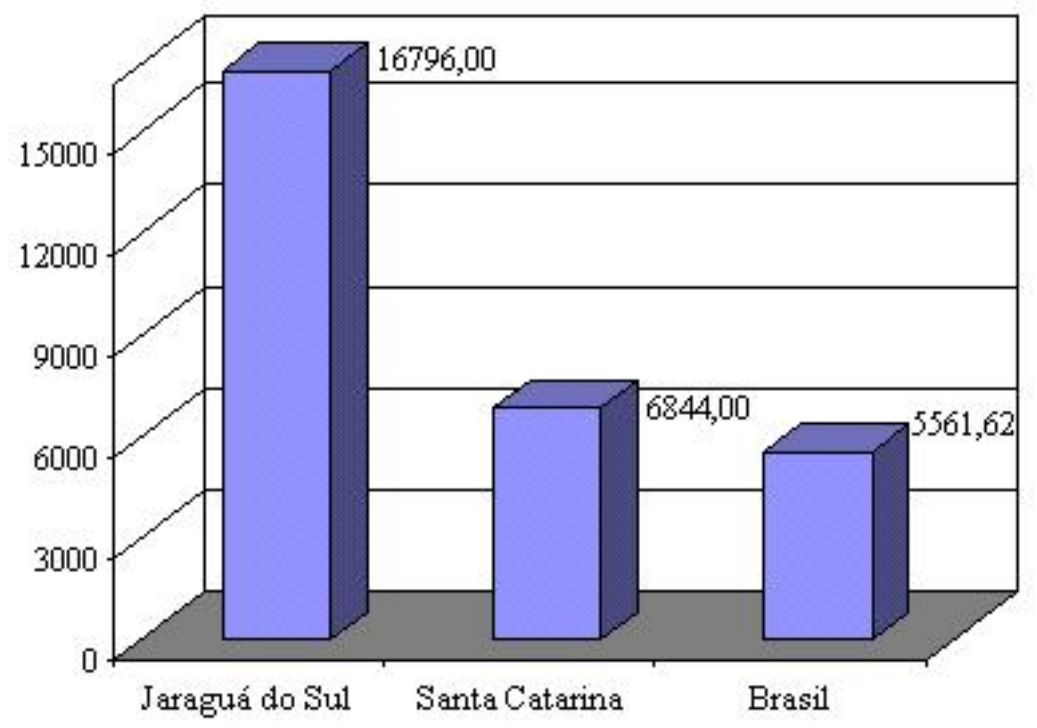

FIGURA 2 - Comparativo renda per capita - Município/Estado/País

FONTE: Secretaria de Administração e Finanças/PMJS/1999

Jaraguá do Sul, cidade que abriga a empresa analisada, apresenta uma elevada renda per capita que chegou a $\mathrm{R} \$ 16.796,00$, enquanto que o Estado possui renda de $\mathrm{R} \$ 6.844,00$ e o Brasil somente $\mathrm{R} \$ 5.561,62$. Além disso, apresenta outros dados que a atesta como uma das cidades de melhor qualidade de vida do Estado de Santa Catarina. É considerada também a cidade que mantém a mais bem treinada força de trabalho (competente, disciplinada e trabalhadora). (Jaraguá em dados, 2000). 


\subsection{Jaraguá Do Sul: Grandeza Pelo Trabalho}

O município ${ }^{7}$ de Jaraguá do Sul, como demonstra o mapa abaixo, localiza-se no Vale do Itapocu, Estado de Santa Catarina. Ele é rodeado por montanhas verdes e belas paisagens. A mata atlântica ainda é sua vegetação típica. O clima é subtropical com verão quente e inverno úmido e dista $185 \mathrm{~km}$ de Florianópolis. É uma cidade com predominância econômica urbano-fabril sem, contudo, apresentar problemas semelhantes aos centros densamente industrializados.

O município limita-se ao norte com Campo Alegre e São Bento do Sul; ao sul, com os Municípios de Rio dos Cedros, Pomerode, Blumenau e Massaranduba; ao leste com Guaramirim, Schroeder e Joinville; e a oeste com Corupá. Jaraguá do Sul lidera o pólo industrial que se expande por todos esses municípios; perde somente para Joinville.

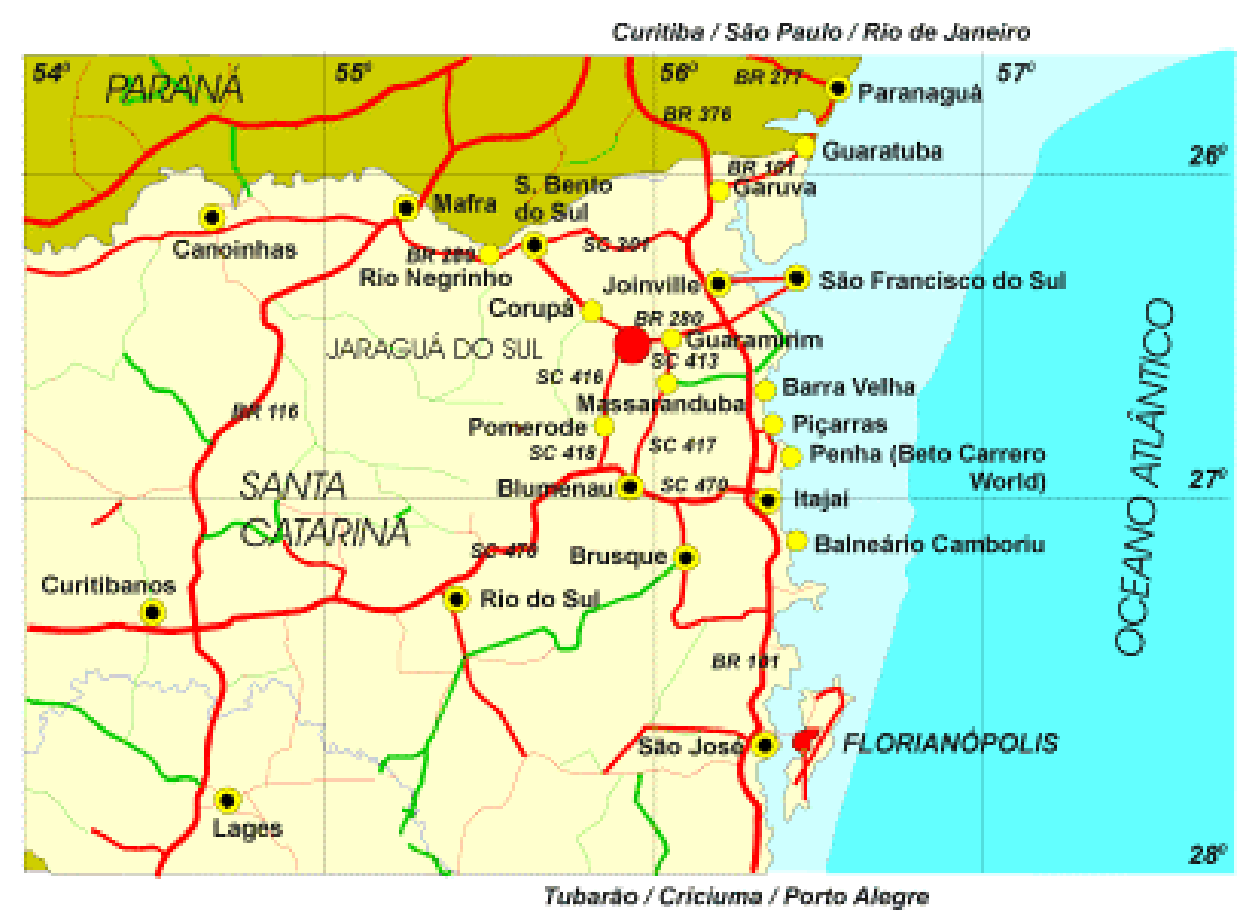

FIGURA 3 - Jaraguá do Sul e municípios vizinhos.

7 Essas informações estão disponíveis no site http://www.jaraguadosul.com.br. 
Em termos econômicos, apresentou o maior Produto Interno Bruto ( $\mathrm{R} \$ 9.583,00)$ do Estado de Santa Catarina ${ }^{8}$, segundo dados de 1995 da Prefeitura Municipal de Jaraguá do Sul.

Esse município, sede da empresa, é cortado pelos rios Itapocu e Jaraguá, dentre outros, e também por uma linha ferroviária que o interliga à cidade portuária de São Francisco do Sul $^{9}$. Jaraguá do Sul está a $55 \mathrm{Km}$ de São Francisco do Sul, bem como de Joinville e de Blumenau. Possui uma boa rede de estradas, a BR-280; a SC-416 e SC-418; a BR-101 e a SC 301. É uma cidade bem provida de acessos e isso facilita contatos com outras cidades e regiões para a realização de intercâmbio comercial. O mapa abaixo demonstra a multiplicidade desses acessos:

\footnotetext{
${ }_{9}^{8}$ Jaraguá em dados, 1998, p. 63.

${ }^{9}$ Os principais portos do Estado são os da cidade de Imbituba, Itajaí e em São Francisco do Sul. O porto de São Francisco do Sul exporta sobretudo os produtos da empresa analisada.
} 


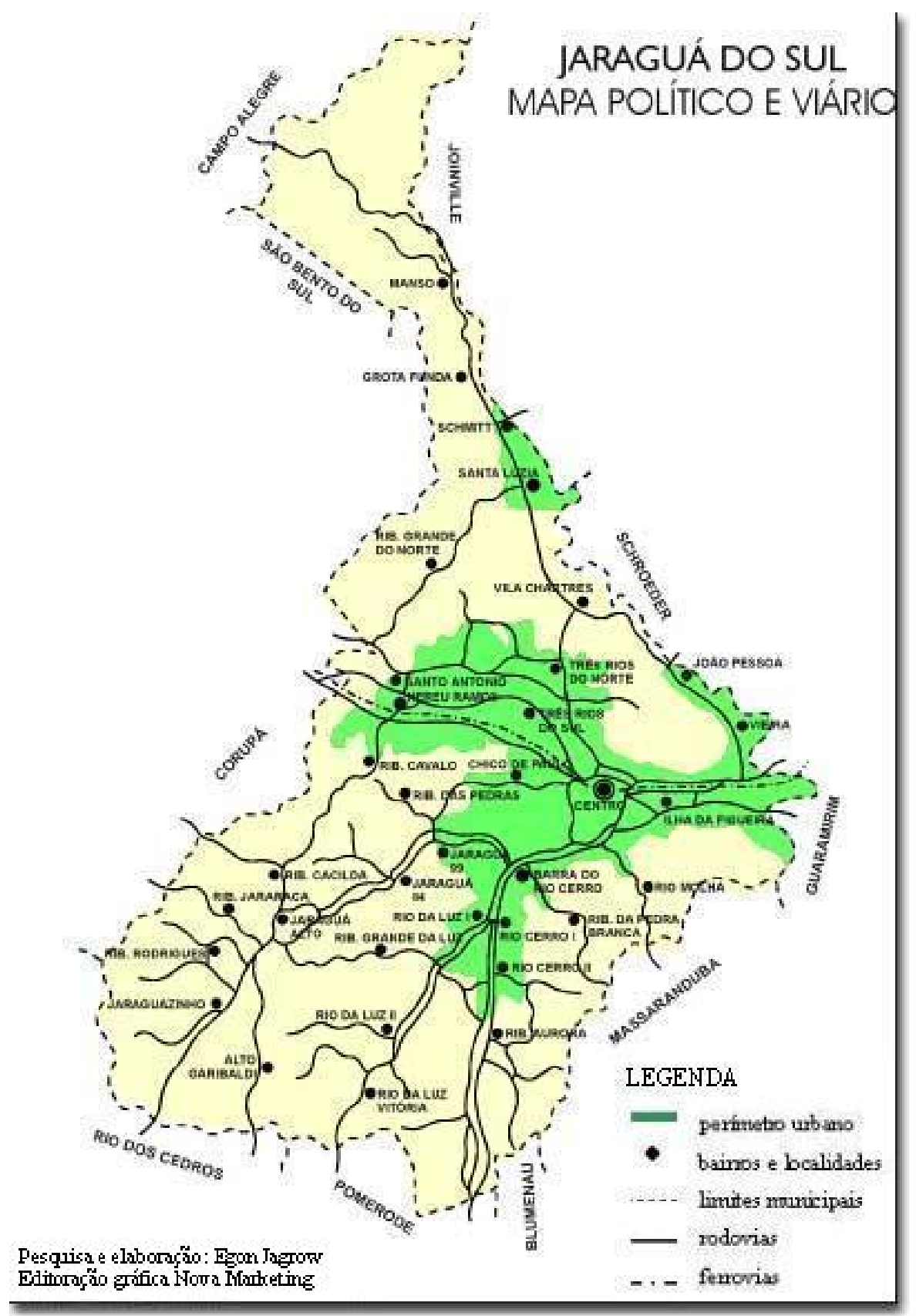

FIGURA 4 - Mapa político e viário de Jaraguá do Sul

Segundo Schörner (2000), os contatos entre as cidades, bem como a troca de informações, de matéria-prima e de produtos, influencia e influenciou decisivamente o processo de industrialização da cidade de Jaraguá do Sul, principalmente a partir da década de 1960.

$\mathrm{Na}$ cidade existem poucas ruas sem asfaltamento. As estradas asfaltadas possuem linearmente 95.969,45 metros, com lajotas, 45.906,60 metros lineares e 76.846,90 metros lineares pavimentados com paralelepípedo. 
Em Jaraguá do Sul são produzidas diferentes mercadorias que vão desde artigos de malhas, confecções, chapéus, gêneros alimentícios, motores elétricos, geradores, máquinas, móveis, componentes eletrônicos e de informática. Essas indústrias empregam uma grande parcela dos trabalhadores catarinenses, cerca de 25.000 trabalhadores.

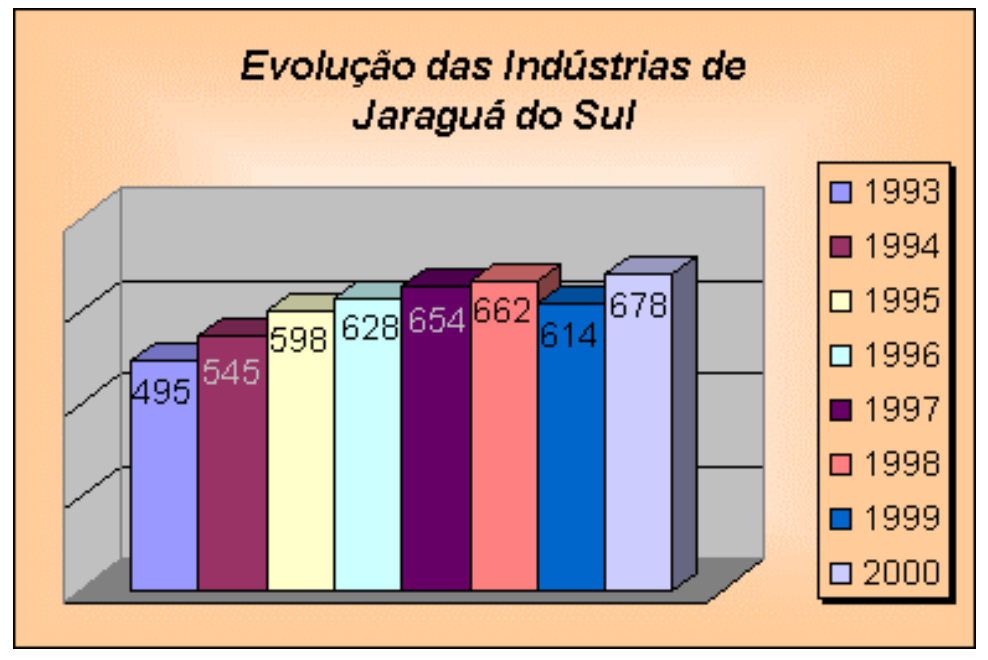

FIGURA 5 - Evolução das indústrias de Jaraguá do Sul

A industrialização dessa cidade, desencadeada com força a partir da década de 1970, vem obedecendo a uma curva ascendente de crescimento, com certo percalço em fins da década de oitenta desse mesmo século. Percebemos que, mesmo com índices que a destacam das demais cidades, tanto nacionalmente como localmente, ela não deixa de sofrer os problemas oriundos de um contexto social maior. Foi assim, no final da década de 1980. No final da década de 1990, ela retrocede um pouco na curva de ascensão econômica, como expresso em números na figura acima, porém, o crescimento foi restabelecido logo em seguida. Os poderes políticos locais interferem e tomam medidas com vistas à manutenção desse crescimento; por exemplo, sancionaram uma lei de incentivo à implantação de novas empresas no município, a lei Complementar $n^{\circ}$ 18/99, de 2 de dezembro de 1999, a qual se coaduna ao Plano ${ }^{10}$ Municipal de Incentivo às Empresas.

$10 \mathrm{O}$ apoio do município expressa-se por meio de:

- cessão de uso de área por prazo determinado;

- $\quad$ execução de serviços de terraplenagem, aterros e vias de acesso ao conjunto industrial;

- rede de água, esgoto e galerias pluviais;

- isenção de taxa de licença para localização e permanência no local; do Imposto sobre a Propriedade Predial e Territorial Urbana; de emolumentos relativos à análise e aprovação de projetos; do Imposto sobre Transmissão de Bens Imóveis (por prazos determinados); 
Na tabela abaixo, vemos que em 1999 Jaraguá do Sul reflete e acompanha o desaquecimento da economia nacional. O decréscimo do PIB é significativo; em praticamente trinta anos houve uma baixa na produção de quase 93\%. E, em fins da década de 1990, a baixa, em relação aos anos anteriores, é visível nos dados. Esses dados parecem indicar paralisação da produção nacional.

TABELA 1 - Evolução do Produto Interno Bruto do Brasil - 1970/1999

\begin{tabular}{c|c}
\hline Ano & Variação (\%) \\
\hline 1970 & 10,4 \\
\hline 1971 & 11,4 \\
\hline 1972 & 11,9 \\
\hline 1973 & 13,9 \\
\hline 1974 & 8,3 \\
\hline 1975 & 5,1 \\
\hline 1976 & 10,2 \\
\hline 1977 & 4,9 \\
\hline 1978 & 4,9 \\
\hline 1979 & 6,8 \\
\hline 1980 & 9,3 \\
\hline 1981 & 4,3 \\
\hline 1982 & 0,8 \\
\hline 1983 & 2,9 \\
\hline 1984 & 5,4 \\
\hline
\end{tabular}

\begin{tabular}{c|c}
\hline Ano & Variação $\mathbf{( \% )}$ \\
\hline 1985 & 7,8 \\
\hline 1986 & 7,5 \\
\hline 1987 & 3,5 \\
\hline 1988 & 0,1 \\
\hline 1989 & 3,2 \\
\hline 1990 & 4,3 \\
\hline 1991 & 1,0 \\
\hline 1992 & 0,5 \\
\hline 1993 & 4,9 \\
\hline 1994 & 5,9 \\
\hline 1995 & 4,2 \\
\hline 1996 & 2,7 \\
\hline 1997 & 3,6 \\
\hline 1998 & 0,1 \\
\hline 1999 & 0,8 \\
\hline
\end{tabular}

FONTE: Banco Central de Brasil (cf. DIEESE, 2000).

A repercussão dessa baixa de produção atinge também o comércio, como vemos na Figura abaixo, em 1999 houve um decréscimo em relação ao ano anterior.

- implantação ou melhoria de rede de energia elétrica e iluminação pública;

- isenção de ISS para as obras e serviços executados para a implantação e/ou ampliação de projetos das entidades beneficiadas por essa lei. (Jaraguá em dados, 2000) 


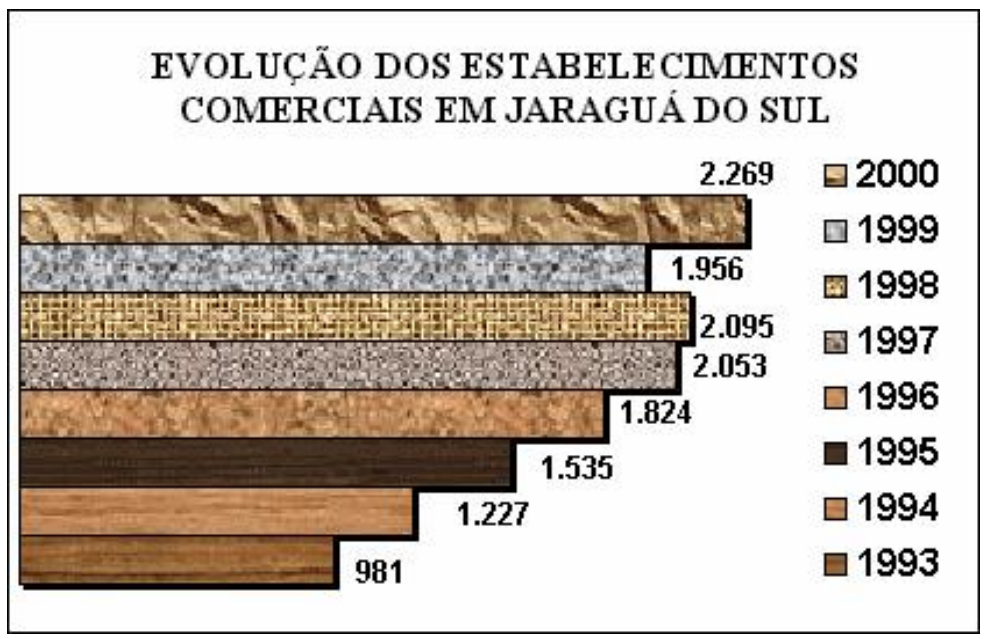

FIGURA 6 - Evolução dos estabelecimentos comerciais em Jaraguá do Sul

Porém, o setor de serviço não acompanha essa variação imediatamente e só é atingido no ano seguinte. Vejamos abaixo a figura:

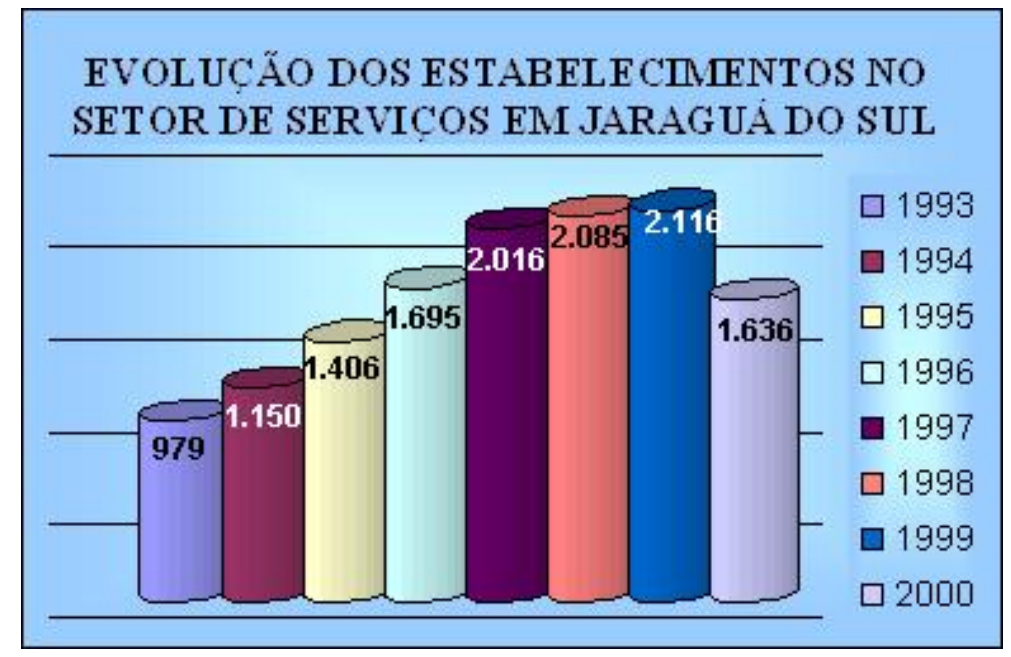

FIGURA 7 - Evolução dos estabelecimentos no setor de serviços em Jaraguá do Sul

A área da saúde tem uma infra-estrutura invejável quando comparada aos índices do próprio Estado e do Brasil. É desenvolvido pelo poder público um trabalho de prevenção que inclui vacinação, fiscalização sanitária e cuidados na manipulação dos alimentos, conforme informações da PMJS (2001). A cidade dispõe de 100 leitos no Hospital e Maternidade São José, sendo 9 de UTI; no Hospital e Maternidade Jaraguá há 123 leitos, sendo 40 pediátricos e 10 para pacientes de UTI.; há 17 postos de saúde. 
Porém, apesar de todas essas condições, na tabela abaixo, vemos que existem dados instigadores: a única faixa etária com menor número de mortes é a de 45 anos a 64 anos, pois nas outras a porcentagem é sempre maior em relação ao Estado de Santa Catarina. Relacionando esses dados ao Brasil, Jaraguá do Sul só perde na faixa de 01 a 14 anos. Vejamos a Tabela:

TABELA 2 - Mortalidade proporcional por faixa etária (\%)

\begin{tabular}{l|c|c|c}
\hline & Brasil & Santa Catarina & Jaraguá do Sul \\
\hline Menores de 1 ano & 8,3 & 6,4 & 6,8 \\
\hline De 1 a 14 anos & 2,9 & 3,0 & 3,13 \\
\hline De 15 a 44 anos & 19,5 & 18,1 & 20,02 \\
\hline De 45 a 64 anos & 23,6 & 24,6 & 18,37 \\
\hline De 65 ou mais anos & 45,7 & 48,0 & 51,14 \\
\hline
\end{tabular}

FONTE: DATA SUS - Secretaria da Saúde 1997 - PMJS

Observamos, nos dados expostos na tabela a seguir, que mostra dados estatísticos sobre as especificidades dessas mortes, dois deles chamam atenção: um é sobre acidentes de trabalho, a tabela não dispõe de nenhum número, mas sendo uma cidade altamente industrializada, seria um tanto óbvio que existissem dados sobre acidentes de trabalho e que fossem significativos; a outra questão é que o número de mortes por suicídios ${ }^{11}$, em relação ao Brasil, é bastante elevado e, em relação ao Estado, os índices são superiores. As doenças mais ameaçadoras são do grupo das doenças do coração, cérebro - vasculares e do aparelho digestivo.

\footnotetext{
${ }^{11}$ Um trabalhador entrevistado no chão da Fábrica $X$ citou esse dado e o máximo de informação conseguida sobre esse assunto foi essa Tabela, publicada em Dados da Prefeitura de 1997, referindo-se até o ano de 1997. Ouvimos das pessoas da cidade, quando coletávamos informações sobre o assunto que: alemão não pode ver uma corda, pois pensa logo em se enforcar (adágio popular local).
} 
TABELA 3 - Taxa específica de mortalidade (100.000 habitantes - habitantes Jaraguá do Sul)

\begin{tabular}{l|c|c|c}
\hline & Brasil & Santa Catarina & Jaraguá do Sul \\
\hline Acidentes de trabalho & 21,6 & 26,6 & - \\
\hline Acidentes de transporte & 23,7 & 41,0 & 9,1 \\
\hline Afecções peritoniais (p/1.000 nasc. Vivos) & 11,3 & 8,6 & 4,8 \\
\hline AIDS & 9,6 & 8,6 & 2,0 \\
\hline Cirrose hepática & 8,0 & 7,7 & 0,83 \\
\hline Diabetes melitus & 16,8 & 15,6 & 11,0 \\
\hline Doenças cérebro vasculares & 51,6 & 57,3 & 59,0 \\
\hline Homicídios & 24,8 & 8,3 & 7,0 \\
\hline Insuficiência do coração & 46,9 & 50,4 & 40,0 \\
\hline Neoplasias da mama & 4,6 & 4,2 & 2,0 \\
\hline Neoplasias da próstata & 7,8 & 7,5 & 4,0 \\
\hline Neoplasias do aparelho digestivo & 21,2 & 25,2 & 24,0 \\
\hline Neoplasias do aparelho respiratório & 8,0 & 11,0 & 7,0 \\
\hline Neoplasias do útero & 7,6 & 8,3 & 2,0 \\
\hline Suicídios & 4,3 & 7,8 & 10,0 \\
\hline
\end{tabular}

FONTE: DATA SUS - Secretaria da Saúde 1997 PMJS

Quanto às doenças evitáveis, os dados abaixo expressam que, de fato, há prevenção efetivada pela política pública de saúde local; inclusive, o tétano, a difteria e a raiva humana estão erradicados e há apenas um caso de coqueluche e um de sarampo.

TABELA 4 - Casos confirmados de doenças evitáveis por imunização (unidades)

\begin{tabular}{l|c|c|c}
\hline & Brasil & Santa Catarina & Jaraguá do Sul \\
\hline Coqueluche & 963 & 21 & 1,0 \\
\hline Difteria & 101 & 0 & 0,0 \\
\hline Hepatite B & 8.065 & 1.467 & 27,0 \\
\hline Raiva humana & 25 & 0 & 0,0 \\
\hline Sarampo & 835 & 111 & 1,0 \\
\hline Tétano neonatal & 85 & 0 & 0,0 \\
\hline Tétano (outros) & 724 & 0 & 0,0 \\
\hline
\end{tabular}

FONTE: DATA SUS - Secretaria da Saúde 1997 - PMJS

Segundo dados da prefeitura, $100 \%$ da população é abastecida com água potável. A rede de esgoto chega a $60 \%$ da população, havendo três estações de tratamento. Quase $100 \%$ da população urbana é atendida com coleta de lixo domiciliar. Esses dados, expostos na próxima tabela, em comparação com os do Brasil e de Santa Catarina, sempre estão indicando vantagem para Jaraguá do Sul. 
TABELA 5- Saneamento básico (\% da população urbana servida)

\begin{tabular}{l|c|c|c}
\hline & Brasil & Santa Catarina & Jaraguá do Sul \\
\hline Abastecimento de água (r.geral) & 85,5 & 88,9 & 100 \\
\hline Coleta de lixo & 84,5 & 94,6 & 95 \\
\hline Tratamento do esgoto sanitário & 58,2 & 60,7 & $60^{*}$ \\
\hline Rede de canalização de esgoto & Não disponível & Não disponível & $60^{*}$ \\
\hline Canalização de águas pluviais & Não disponível & Não disponível & 100 \\
\hline
\end{tabular}

FONTE - Ministério da Saúde (RIPSA) * Projeção para abril de 2001

Na tabela abaixo vemos que as condições de vida no que se refere à habitação e ao número de pessoas por dormitório, bem como à construção de casas com materiais duráveis estão bem equacionados. O número de pessoas por dormitório indica também que as famílias estão diminuindo.

TABELA 6 - Indicadores de condições de vida bloco habitação 1970/1980/1991

\begin{tabular}{|c|c|c|c|c|}
\hline & \multicolumn{4}{|c|}{ Porcentagem da população que vive em domicílio com } \\
\hline & $\begin{array}{l}\text { Densidade } \\
\text { superior a } 2 \\
\text { pessoas por } \\
\text { dormitório }\end{array}$ & $\begin{array}{l}\text { Materiais de } \\
\text { construção } \\
\text { duráveis }\end{array}$ & $\begin{array}{l}\text { Abastecimento } \\
\text { adequado de } \\
\text { água }\end{array}$ & $\begin{array}{l}\text { Instalações } \\
\text { adequadas de } \\
\text { esgoto }\end{array}$ \\
\hline & \begin{tabular}{l|l|l|}
1970 & 1980 & 1991 \\
\end{tabular} & \begin{tabular}{|l|l|l|}
1970 & 1980 & 1991 \\
\end{tabular} & \begin{tabular}{|l|l|l|}
1970 & 1980 & 1991 \\
\end{tabular} & \begin{tabular}{|l|l|l|}
1970 & 1980 & 1991 \\
\end{tabular} \\
\hline Jaraguá do Sul & \begin{tabular}{l|l|l|}
24,7 & 16,8 & 9,6 \\
\end{tabular} & \begin{tabular}{|l|l|l|}
87,3 & 99,9 & 99,7 \\
\end{tabular} & \begin{tabular}{|l|l|l|}
53,0 & 92,1 & 98,3 \\
\end{tabular} & \begin{tabular}{l|l|l|}
45,2 & 86,0 & 92,2 \\
\end{tabular} \\
\hline Santa Catarina & \begin{tabular}{l|l|l|}
43,4 & 31,4 & 18,0 \\
\end{tabular} & \begin{tabular}{|l|l|l|}
84,8 & 99,3 & 99,2 \\
\end{tabular} & \begin{tabular}{|l|l|l|}
47,1 & 79,2 & 94,0 \\
\end{tabular} & \begin{tabular}{|l|l|l|}
32,5 & 59,5 & 72,7 \\
\end{tabular} \\
\hline Brasil & \begin{tabular}{l|l|l|}
52,0 & 43,5 & 31,1 \\
\end{tabular} & \begin{tabular}{|l|l|l|}
73,8 & 85,8 & 91,6 \\
\end{tabular} & $51,2670,0083,85$ & 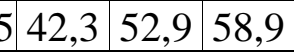 \\
\hline
\end{tabular}

FONTE: Programa das Nações Unidas para o Desenvolvimento - PNUD/ONU/PMJS

No que se refere ao setor primário da economia, ele apresenta também sinais de fortalecimento, mesmo não se constituindo como o setor que define o movimento econômico atual da cidade, apesar dela ser de origem agrícola.

A área rural é de 421,19 $\mathrm{Km}^{2}$ com terras disponíveis. As áreas cultivadas perfazem, segundo dados da EPAGRI, pouco mais do total de 8.500 ha; 6.000 ha, por exemplo, são de pastagens (conforme tabela a seguir). A topografia é acidentada em $50 \%$ da área rural e as propriedades chegam a ter de 10 a 15 ha, sendo menores do que os lotes dos colonos, que eram de 25 ha. 
TABELA 7 - Uso da terra

\begin{tabular}{l|c|c}
\hline \multicolumn{1}{c|}{ Ocupação } & \% & Área (ha) \\
\hline Culturas permanentes & 6,5 & 1.712 \\
\hline Culturas temporárias & 27,0 & 6.872 \\
\hline Em descanso & 19,5 & 5.002 \\
\hline Florestas nativas & 23,5 & 5.891 \\
\hline Pastagens cultivadas & 1,5 & 460 \\
\hline Pastagens nativas & 21,0 & 5.496 \\
\hline Reflorestamento & 1,0 & 431 \\
\hline Total & 100,0 & 25.864 \\
\hline
\end{tabular}

FONTE: IBGE - EPAGRI

$\mathrm{Na}$ agricultura, os principais produtos são: aipim, arroz irrigado, banana, cana-deaçúcar, fumo, milho e olerícolas. Na pecuária, são os seguintes: aves de corte, bovinos de leite, marrecos, peixes e suínos. A mão-de-obra utilizada na propriedade é ainda a familiar, sendo insignificante e onerosa a mão-de-obra contratada. As atividades classificadas por atividades em números de estabelecimentos no ano de 1991 pela EPAGRI foram:

TABELA 8 - Classes de atividades econômicas

\begin{tabular}{l|c|c}
\hline \multicolumn{1}{c|}{ Atividades } & Estabelecimentos & Área (ha) \\
\hline Agricultura & 768 & 13.435 \\
\hline Agropecuária & 97 & 1.510 \\
\hline Avicultura & 112 & 1.564 \\
\hline Cuni, api e sericultura & 2 & 19 \\
\hline Extrativa vegetal & 13 & 2.445 \\
\hline Horticultura e floricultura & 11 & 137 \\
\hline Pecuária & 927 & 10.740 \\
\hline Silvicultura & 9 & 387 \\
\hline Total & 1.939 & 30.237 \\
\hline
\end{tabular}

FONTE: IBGE - EPAGRI 


\subsubsection{RETROCEDENDO NO TEMPO... COLONIZAÇÃO E INDUSTRIALIZAÇÃo}

A região geográfica onde se encontra Jaraguá do Sul pertenceu à Princesa Isabel ${ }^{12}$, que a ganhou como dote ao se casar com o Conde d'EU, nos idos de 1864. A incumbência para demarcar e desbravar essas terras, no entanto, foi dada a um amigo do Conde d'EU: o coronel honorário do Exército Brasileiro, Emílio Carlos Jourdan ${ }^{13}$. No início, eram 12 léguas de terra, posteriormente, elas foram aumentadas para 25 léguas quadradas (Schörner, 2000).

Em 1876 o coronel Jourdan deu inicio à colonização ${ }^{14}$ da região que passou a ser chamada de Colônia Jaraguá. Ele chama seu empreendimento de Estabelecimento Jaraguá; Jaraguá era o nome de um rio e de um morro. A cidade, no século XX, recebeu o nome de Jaraguá do Sul para evitar confusões, uma vez em que existia um outro município com o nome de Jaraguá, no Estado de Goiás. Dessa forma tornam-na Município em 31 de dezembro de 1943, pelo Decreto-lei Estadual n. ${ }^{\circ} 941$.

A demarcação dessas terras possibilitou a vinda de pessoas que ali foram se estabelecendo. No local foram construídos engenhos de açúcar, de farinha de mandioca e de fubá, olaria, serraria e plantado lavouras de cana-de-açúcar. O coronel trouxe 60 trabalhadores, 54 negros e 6 brancos. Esses homens construíram uma certa infra-estrutura nesse local (Jaraguá em dados, 2001). Eles criaram um acesso para São Francisco do Sul e para Joinville, e tentaram tornar navegável o rio Itapocu. Posteriormente, construíram uma ferrovia que liga Jaraguá do Sul ao porto de São Francisco.

Na segunda metade do século XVIII, a agricultura, no Estado de Santa Catarina, entra em decadência, só vindo a melhorar no século XIX, impulsionada pela imigração. Era o final do governo de Dom Pedro I (1822-1831). Foi nesse momento que esse Estado passou a

\footnotetext{
${ }^{12}$ Princesa Isabel era a primogênita do imperador Dom Pedro II, o seu nome completo era: Isabel Cristina Leopoldina Augusta Michaela Gabriela Rafaela Gonzaga de Bragança e o seu casamento com o Conde d'EU aconteceu em 15 de outubro de 1864, o Imperador Dom Pedro II e a Imperatriz Teresa Cristina determinaram um dote de terras, cuja localização foi estabelecida por ato, assinado em 17 de outubro de 1870, fixando em 98 léguas a serem escolhidas nos estados de Santa Catarina e Sergipe.

${ }^{13}$ Emílio Carlos Jourdan era belga naturalizado brasileiro. Engenheiro militar, com destacada atuação na Guerra do Paraguai.

${ }^{14}$ Segundo dados históricos da prefeitura sobre essa época, nessa região existiam índios, os botocudos (hoje chamados xokleng); viviam pela mata, sendo presa fácil para os aliciadores de mão-de-obra. Em poucas décadas, foram praticamente exterminados pelos bugreiros e pelas doenças contraídas no contato com o homem branco.
} 
receber um novo fluxo de imigrantes, que vieram para devido estímulos oficiais e também por iniciativa particular. Em 1829 foi instalada a primeira colônia alemã, por iniciativa do governo. Contudo, essas iniciativas não conseguiram muito sucesso e só por meio das companhias particulares é que houve a proliferação das colônias, sempre ao longo dos vales e dos rios Itajái-Açu, Itajaí-Mirim e Itapocu. Dessas colônias surgiram cidades como Joinville, Blumenau, Brusque e, posteriormente, Jaraguá do Sul, as quais tornaram-se pólos industriais importantes nesse estado.

A partir de 1890, colonos alemães fixaram-se em terras circunvizinhas do Rio do Serro e do Rio da Luz. Em 1891, os húngaros passaram a ocupar as colônias próximas dos rios Garibaldi, Jaraguazinho e Jaraguá e, em 1893, chegaram italianos que ocuparam terras próximas ao Rio do Serro. Os lotes coloniais possuíam cerca de 25 ha.

O mapa da colonização abaixo demonstra visualmente a distribuição territorial da colonização de Jaraguá do Sul: 


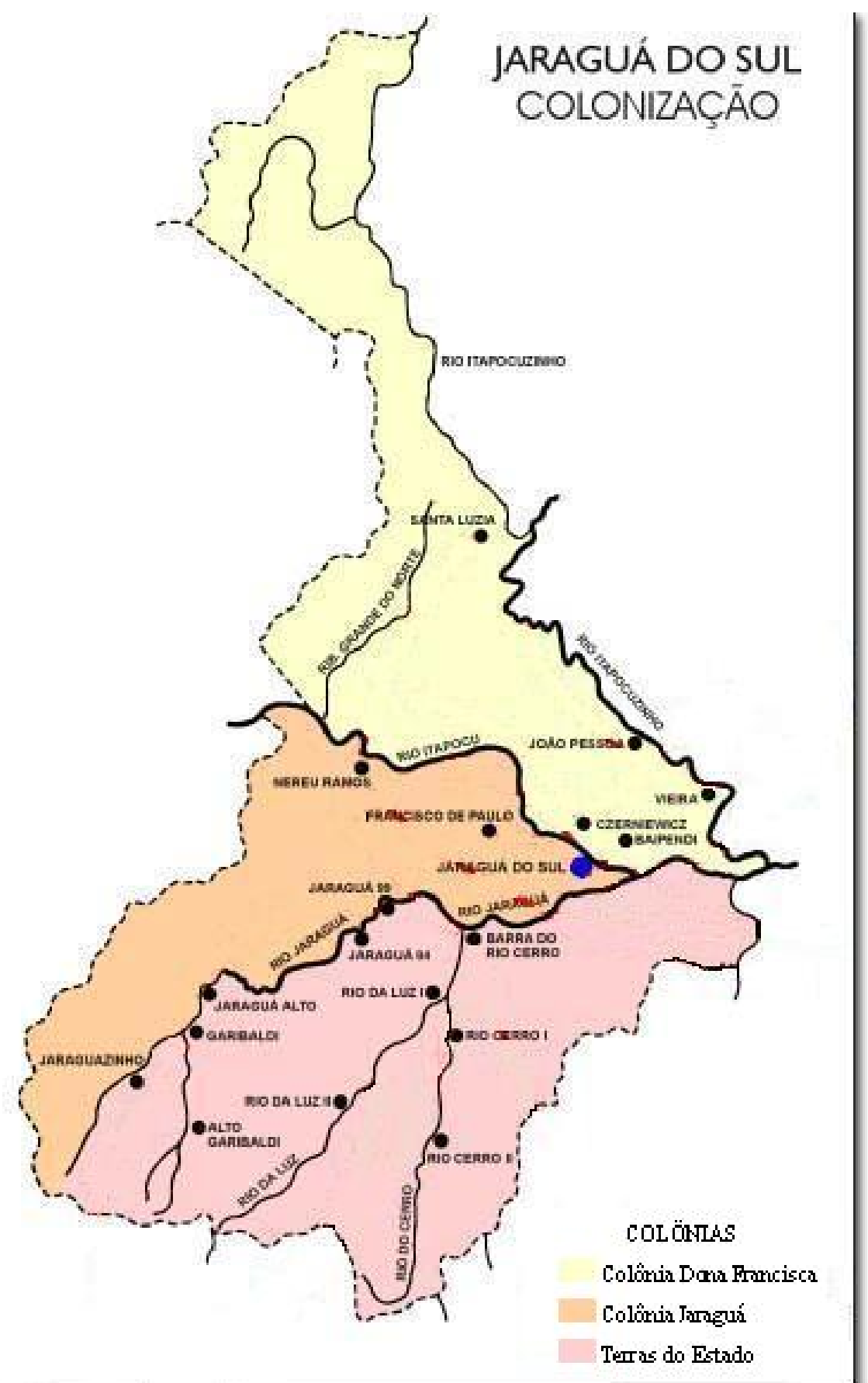

FIGURA 8- Mapa da colonização

Em 1912, o distrito de Jaraguá tinha somente uma população em torno de 8.000 habitantes. Dessas oito mil pessoas, 2.000 falavam português, 1.000 italiano, 500 polonês e 4.500 a língua alemã ${ }^{15}$. Tais dados mostram a influência cultural predominante dos

\footnotetext{
${ }^{15}$ http://www.jaraguadosul.com.br/histórico.htm. 02/12/2001, p.4
} 
descendentes alemães. Para termos uma noção dessa influência, no início do século XX, editais públicos eram divulgados em dois idiomas simultâneos, português e alemão ${ }^{16}$.

$\mathrm{Na}$ pequena propriedade agrícola os colonos organizavam a divisão do trabalho por todos os membros da família que pudessem trabalhar. A produção familiar e em pequena escala determinava a vida dos colonos. A fabricação de produtos agrícolas era voltada para o consumo próprio e apenas o excedente era comercializado. A busca de trabalho fora da propriedade era uma exceção (Schörner, 2000). Nessa época, a economia desenvolvida era essencialmente voltada para a subsistência. Entretanto, o aumento das próprias famílias dos colonos obriga alguns de seus membros a buscar trabalho fora de suas propriedades e a produzir excedentes para serem vendidos aos donos das vendas que os comercializavam dentro e fora da colônia. Os vendeiros criam com isso capital para montar pequenas fábricas domésticas como queijarias, fábricas de banha e salames, alambiques, serrarias e olarias. Esse processo, acompanhado da vinda incessante de mais imigrantes, e a busca de trabalho assalariado pelos colonos, constituíram condições que permitiram o desenvolvimento da industrialização em Jaraguá do Sul e em Santa Catarina.

A soma de diversos fatores, segundo Schörner (2000) é que vai facilitar o desenvolvimento da industrialização da cidade de Jaraguá do Sul e não somente a vontade particular de algumas pessoas.

Há vários elementos que convergem para a consolidação desta industrialização, da localização geográfica ao acúmulo de capital feito pelos "vendeiros", efeito da colonização que proporcionaram os excedentes e a mão-de-obra do trabalho industrial. Com o crescimento das famílias e a diminuição das terras disponíveis para cultivo há um excedente de mão-de-obra que já tinha o hábito de nas épocas de entre-safra buscar "serviço" mais para a área que breve se tornaria urbana (p.53).

Assim, com o desenvolvimento do comércio na colônia, gera-se uma das condições de viabilização e surgimento de pequenas fábricas. Os colonos vendedores de produtos, principalmente agrícolas, vão pouco a pouco cedendo lugar para os produtos industriais, oriundos das fábricas. É a produção de mercadorias em maior escala que permite ao vendeiro passar de uma atividade à outra. Assim, os vendeiros vão alterando seus negócios e a feição da cidade também se altera.

\footnotetext{
${ }^{16}$ http://www.jaraguadosul.com.br/histórico.htm. 02/12/2001, p.3,4
} 
Em 1921, a região começa a receber novos imigrantes europeus, segundo dados, fugidos da devastação que a Europa tinha sofrido pela primeira Guerra Mundial. Vale destacar que esses imigrantes possuíam qualificações técnicas. É preciso lembrarmos também que os imigrantes europeus, habituados ao trabalho compulsório das formas assalariadas, em sua maioria, constituem a condição subjetiva para o processo industrial em expansão. A sua familiaridade com a disciplina da fábrica e do trabalho assalariado, quer pela tradição, educação e pelo hábito, facilita conforme diz Schörner, o sucesso dos empresários. A fama dos alemães, que ainda persiste, advém dessas características sociais. Eles são considerados pessoas trabalhadoras, disciplinadas, metódicas e obedientes, características essenciais para a eficiência do trabalho fabril.

Um aspecto peculiar presente na colonização da cidade de Jaraguá e que repercute até os dias atuais é que não existiu, segundo Schörner (2000, p. 33), um local que pudesse servir como centro de encontro das pessoas das colônias. A colonização não contempla um espaço público que poderia ser utilizado para o exercício de lazer. Segundo esse autor, não existia um local

[...] para onde os colonos se dirigissem regularmente a fim de pagar suas dívidas, vender e trocar mercadoria, buscar ou mandar correspondência, participar das festas da comunidade, assistir aos ofícios religiosos, encontrar os amigos e manter as tradições. Aliás, a falta de um lugar como esse, somada à falta de estradas ou de vias de comunicação, foram fatores que levaram muitos colonos a desistirem de seus lotes, ao mesmo tempo que levaram os que aqui permaneceram, a um relativo isolamento e dependendo, para a sua sobrevivência, dos vendeiros, que instalavam suas casas comerciais nas diversas regiões de colonização.

Voltando-nos para o processo de industrialização em Jaraguá do Sul, a sua forma é singularizada, mas não foge à regra do que ocorreu em outras colônias de Santa Catarina:

No sul do Brasil, Santa Catarina expressa esse movimento de ocupação européia. Aqui ocorre um turbilhão de mudanças: ao invés de índios e "nativos" os colonizadores impõem uma outra forma de viver, em detrimento daquela vigente. Com a imigração ocorre o processo de industrialização, sendo a têxtil o carro chefe. $\mathrm{Na}$ base destes dois processos, estão tanto a vinda de novos personagens sociais, como alterações materiais (lembremos que a cultura também tem materialidade) radicais, sendo a iluminação apenas um exemplo. Isto tudo se realiza depois da proclamação da Independência, em 1822, quando o governo brasileiro passa a estimular a emigração dos europeus e com este intuito, são formadas diversas colônias oficiais. Ao mesmo tempo, são feitas diversas concessões para empresas privadas promoverem a instalação dos imigrantes. No Rio Grande do Sul os primeiros imigrantes alemães chegaram a São Leopoldo, em 1824. Em Santa Catarina, a colonização alemã e italiana desencadeia-se a partir de São Pedro de 
Alcântara, em 1829, próximo a Florianópolis. Os europeus italianos chegam em 1836 e fundam as colônias italianas, Nova Itália e Nova Trento, às margens do rio Tijucas. Depois são fundadas as alemãs, Joinville, ao norte, e Blumenau, no Vale do Itajaí, em 1850. A seguir, Brusque, no Vale do Itajaí Mirim, em 1860. Os italianos ainda fundam, a partir de 1875 , Criciúma e Urussanga, através do Vale do rio Tubarão. [Jaraguá do Sul em 1876]. (Singer, 1968, p. 2).

A partir de 1950, a industrialização de Jaraguá do Sul foi incrementada consideravelmente, por um lado, com a vinda de empresários de fora, e, por outro, pela existência de colonos que acabaram se tornando assalariados. Para isso concorreu, decisivamente, a impossibilidade deles tornarem-se pequenos produtores independentes.

Esse processo, segundo Schörner (2000) é fundado por meio da compra e da venda de produtos coloniais, constituindo uma das bases para o surgimento da fábrica moderna capitalista. Todavia, essa formulação é ainda insuficiente para explicar o surgimento da industrialização local. O sucesso desse empreendimento ocorre por meio de outras relações que se estabelecem também por meio da chegada de novos empreendedores, vindos de outras regiões já com disponibilidade financeira, unindo meios de produção e trabalho. Esse é um dos segredos do florescimento da industrialização catarinense.

\footnotetext{
No Estado a industrialização não se impõe com a mesma força em todo o território catarinense. Ao mesmo tempo é una e diversa, a soma e a síntese das partes que integram as histórias regionais. $\mathrm{O}$ processo industrializante não é abrupto e desenvolve-se somente a partir do período entre 1890 e 1920. Em 1907, o Estado possui apenas 171 estabelecimentos industriais e 2068 trabalhadores. Em 1920, os estabelecimentos industriais elevam-se em $21,62 \%$ a mais do que na década anterior. Entre 1920 e 1940, crescem 27,78\% e o maior acréscimo registrado observa-se entre as décadas de 40 e 50, com incremento de 55,94\% (Aued, 1999, p. 47).
}

A colonização européia facilitou a relação comercial do sul do Brasil com alguns países europeus, vale dizer, no estabelecimento de vínculos econômicos mundiais que extrapolaram a esfera doméstica. Nesse sentido, podemos afirmar que a colonização conecta o Estado de Santa Catarina ao circuito internacional.

Com a eclosão da Primeira Guerra Mundial, as importações brasileiras foram reduzidas. Conforme Singer (1968, p.122), nesse momento várias fábricas surgem em Santa Catarina: Blumenau, que de fato é o primeiro pólo fabril no Estado, o de Joinville e o de Jaraguá do Sul. 
O fluxo de imigrantes alemães não se restringe aos locais mencionados, mas difunde-se por todo o Vale do Rio Itajaí. Em decorrência, nessa época sucedem fatos de grande repercussão local:

Em 1937, dezesseis núcleos de descendentes de alemães são considerados desintegrados do ambiente nacional. Isso se refere aos Municípios do Vale do Rio Itajaí: Hamônia, Blumenau, Brusque, Indaial, Rio do Sul e Timbó; aos Municípios do norte do Estado: Jaraguá do Sul, Joinville, São Bento do Sul e Porto União; ao Município da zona central: Bom Retiro; aos municípios do oeste: Cruzeiro, Concórdia, Campos Novos e Chapecó, com várias e densas colônias à margem do Rio Uruguai; ao Município do sul: Tubarão (Fiod, 2002, p. 45).

O governo brasileiro, nessa época, inicia um processo denominado de integração nacional, que culmina com o fechamento de quase todas as escolas em outras línguas. Em Jaraguá do Sul, em 1938, é fechada a Escola Alemã, que reabre em 1953 com o nome Escola Particular Jaraguá. ${ }^{17} \mathrm{O}$ governo interdita a utilização da língua estrangeira no cotidiano. Como o conhecimento da língua portuguesa era, até então, muito precário, os colonos vêem-se forçados a restringir os seus contatos sociais.

No período entre guerras, registra-se um intenso desenvolvimento industrial (Singer, 1968, p. 130). A produção de mercadorias expande e muitas delas são diretamente exportadas pelo porto da cidade de São Francisco do Sul.

Em 1872, o Estado de Santa Catarina contava com 158 mil habitantes; no final do Império, em 1889, já alcançava 320 mil, ou seja, praticamente o dobro de pessoas em apenas uma década e meia. No final do século XX, sua população era de 5.333.284 habitantes.

Em Jaraguá do Sul a população tem significativo crescimento e acompanha ao mesmo tempo o desenvolvimento da industrialização. Contando em 1940 com 23.495 pessoas, chega ao ano 2000 com 108.377, como vemos na Figura próxima:

\footnotetext{
${ }^{17}$ De acordo com Jaraguá em dados, 1998' p.61.
} 


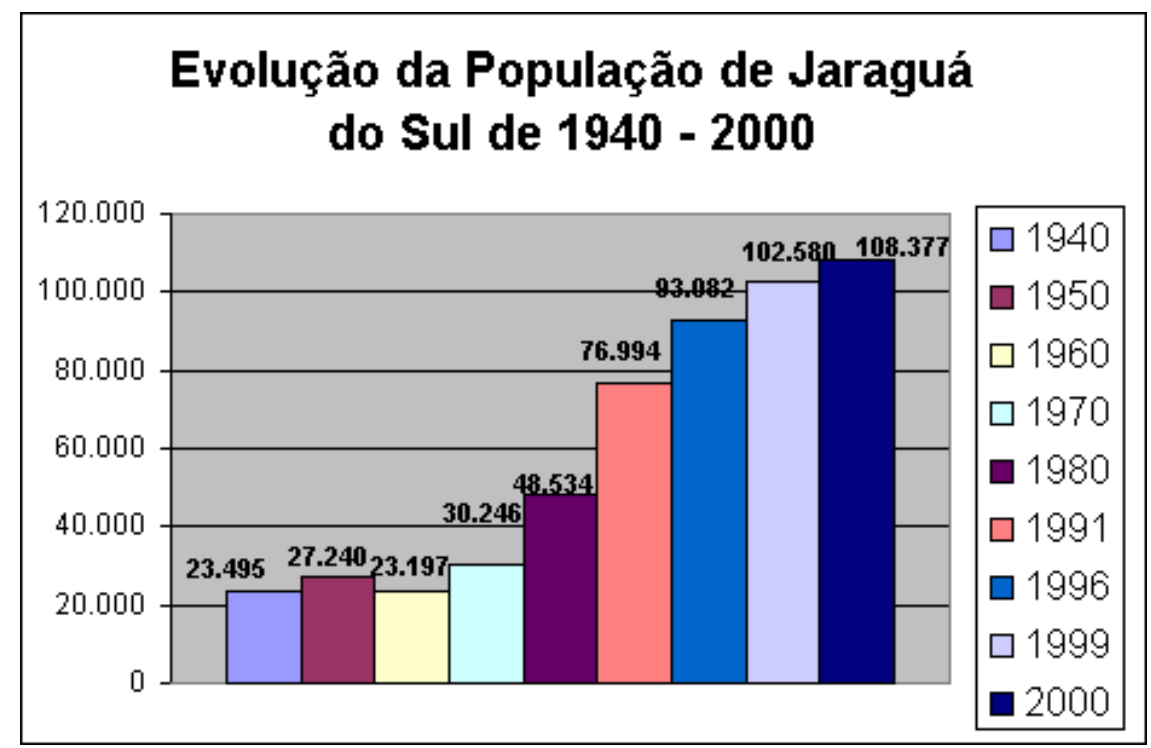

FIGURA 9- Evolução da população de Jaraguá do Sul

No crescimento populacional constatamos um fenômeno paralelo: a urbanização. No Brasil, assim como também em Santa Catarina, ocorre um significativo deslocamento da população do campo para a cidade, como podemos ver na tabela a seguir.

TABELA 9 - População recenseada no Brasil e em Santa Catarina, por situação do domicílio e participação relativa no país, na data dos Censos 1940/2000.

\begin{tabular}{|c|c|c|c|c|c|c|c|}
\hline \multirow{3}{*}{ DATAS } & \multicolumn{7}{|c|}{ População recenseada } \\
\hline & \multicolumn{3}{|c|}{ Brasil } & \multicolumn{3}{|c|}{ Santa Catarina } & \multirow{2}{*}{$\begin{array}{c}\mathrm{SC} / \mathrm{BR} \\
(\%)\end{array}$} \\
\hline & Total & Urbana & Rural & Total & Urbana & Rural & \\
\hline 1940 & 41.236 .315 & 12.880 .182 & 28.356 .133 & 1.178 .340 & 253.717 & 924.623 & 2,86 \\
\hline 1950 & 51.944 .397 & 18.782 .891 & 33.161 .506 & 1.560 .502 & 362.717 & 1.197 .785 & 3,00 \\
\hline 1960 & 70.070 .457 & 31.303 .034 & 38.767 .423 & 2.129 .252 & 688.358 & 1.440 .894 & 3,04 \\
\hline 1970 & 93.139 .037 & 52.084 .984 & 41.054 .053 & 2.901 .734 & 1.246 .043 & 1.655 .691 & 3,12 \\
\hline 1980 & 119.002 .706 & 80.436 .409 & 38.566 .297 & 3.627 .933 & 2.154 .238 & 1.473 .695 & 3,05 \\
\hline 1991 & 146.917 .459 & 110.875 .826 & 36.041 .633 & 4.541 .994 & 3.208 .537 & 1.333 .457 & 3,09 \\
\hline 1996 & 157.070 .163 & 123.076 .831 & 33.993 .332 & 4.875 .244 & 3.565 .130 & 1.310 .114 & 3,10 \\
\hline 2000 & 169.544 .443 & 137.670 .088 & 31.874 .355 & 5.333 .284 & 4.197.287 & 1.135 .997 & 3,14 \\
\hline
\end{tabular}

FONTE: Fundação IBGE - Censo Demográfico/SC, 1940-1996

Tais dados evidenciam o enorme crescimento urbano em Santa Catarina. Em 1940, a população rural é de 924.623 habitantes, enquanto a população urbana é de 253.717 , ou seja, quatro vezes menor do que a população rural. No ano 2000, a população rural soma 1.135.997, enquanto a população urbana conta com 4.197.287 habitantes. Somente cerca de um quarto do total de habitantes do Estado ainda vive na zona rural. Em meio século mudou a 
configuração populacional. A urbanização de Santa Catarina caminha em passos largos conjugada a sua industrialização.

O processo de desenvolvimento econômico das áreas de colonização em Santa Catarina passa por três períodos distintos. Segundo Schörner (2000,p. 48), em relação a Jaraguá do Sul o primeiro período vai da fundação do Estabelecimento Jaraguá, em 1876, até meados de 1930, esse período corresponde à passagem do nível de subsistência e agroexportador da produção para a fase do artesanato. O segundo período é o que resulta de profundas mudanças estruturais, com a presença da energia elétrica, transporte, sistemas de crédito e o desenvolvimento demográfico, permitindo a passagem do artesanato para a pequena indústria. $\mathrm{O}$ terceiro período inicia-se com a inserção da cidade na economia nacional, a partir de 1960. É nesse período que a empresa analisada é fundada em 1961, sendo uma das primeiras.

\section{Segundo Ternes (1997):}

[...] produzir motores numa cidadezinha no interior de Santa Catarina, no ano de 1961, mais do que uma hipótese pouco provável, era mesmo quase um despropósito. Com população de apenas 20 mil habitantes, sem tradição industrial, muito menos na área eletromecânica, sem mão-de-obra qualificada, sem recursos financeiros, uma proposta desse gênero, de fato, era quase uma completa temeridade (p.23).

Na década de 60 do século passado, a transformação de certas indústrias familiares em sociedades anônimas faz praticamente desaparecer as empresas individuais e confere, às últimas, um crescimento jamais visto. Algumas delas, em fins dessa década, começam a ter destaque no mundo, como por exemplo a empresa em questão.

Assim, vimos que a história de Jaraguá do Sul evidencia que os homens de sucesso que ali surgem são exatamente aqueles que não ficaram circunscritos a produzir para a sua subsistência e tampouco ao comércio.

Essa experiência, bastante singular, realiza-se num contexto igualmente singular: a Europa que deu certo (Fiod, 2002). Portanto, podemos afirmar que uma parte expressiva da força de trabalho do lugar se explica por meio da onda migratória que se desloca da Europa para o Brasil, mais especificamente, alemães, italianos e poloneses. Reafirmamos, por 
conseguinte, que o processo de colonização traz em seu bojo a industrialização com base no movimento dos imigrantes europeus e na venda da força de trabalho que foi, em certo sentido, semelhante à da Europa. Os imigrantes que chegaram ao Brasil recriaram relações sociais que já conheciam. Essas influências permanecem até hoje e são marcas fundamentais para compreender tanto o passado, quanto o presente.

\title{
1.3 A EMPRESA DESTACADA: TRABALHO, TRABALHO E TRABALHO
}

Essa empresa lidera a produção de motores elétricos na América Latina e é a quinta produtora no mundo (Ternes, 1997, p.176). Segundo o presidente atual, existem três aspectos que garantem a sua inserção, de forma satisfatória, no mercado tanto nacional quanto mundial:

\begin{abstract}
O primeiro aspecto é, sem dúvida, ter o produto adequado para as necessidades específicas de cada mercado. Depois, a questão da logística, da distribuição, da presença nesses mercados. Nós temos 18 centros de distribuição no mundo e isso é fundamental porque, com a filosofia do just in time, os clientes não estão dispostos a esperar e, em poucas situações, querem correr o risco da importação com transporte marítimo. $\mathrm{O}$ terceiro aspecto, que demora mais, diz respeito à marca [...] criar efetivamente a imagem de que motor elétrico de marca é da empresa [...] é um trabalho de longo prazo. A empresa. está fazendo um grande esforço para fortalecer a sua imagem. Não só com as estratégias de marketing comuns: publicidade, feiras, mídia especializada. Temos isso, mas como nosso negócio é business to business, o grande investimento que fazemos é trazer aqueles que tomam as decisões para conhecer a empresa em Santa Catarina e o Brasil. Esse é o grande investimento para criar essa imagem positiva da empresa. Trazemos cerca de 300 visitantes por ano. Depois, a própria imagem do Brasil começa a melhorar. E se o made in Brazil ainda não ajuda a vender, pelo menos não atrapalha mais (Lucas, 2000, p. 10).
\end{abstract}

A empresa focalizada nessa pesquisa, segundo Ternes (1997, p.46) deve seu sucesso à forma de sua administração, que está pautada no seguinte lema: Trabalho, Trabalho e Trabalho.

O seu nascimento, em 1961, deve-se a três profissionais de diferentes áreas que se associam para fabricar motores elétricos: um bancário, um mecânico e um eletricista. A cidade de Jaraguá do Sul, nessa época, tinha apenas 20 mil habitantes 
Essa empresa tem sua origem explicada por meio de características pessoais de um jovem que se projeta, com mais dois sócios, na construção dos melhores motores elétricos de Jaraguá do Sul. Posteriormente, os melhores do Estado, a seguir, do país e, por último, pretende ser a melhor do mundo no ramo. Pensar grande, esse sempre foi o lema e idéia germinal desses jovens. Segundo Ternes (1997, p.17), o êxito da empresa deveu-se à características presentes nos três sócios.

Um traço marcante de cada uma das três personalidades contribuiu para garantir o êxito da empresa: a disciplina. O espírito de ordem, de trabalho, de obediência e de entrega total às tarefas, aliado ao sentimento da criatividade e da coragem de ousar, marcam a maneira de ser dos três fundadores [...] (Ternes, 1997, p. 16).

Dos três sócios ${ }^{18}$ da empresa, dois residiam na cidade de Jaraguá do Sul e um em Joinville. O sócio eletricista era descendente de alemães da região de Düsselforf. A influência em sua formação foi impulsionada pelo avô materno que oportunizava acesso à revistas sobre eletricidade oriundas da Alemanha. Estudou no SENAI de Joinville e trabalhou em várias oficinas de eletricidade. Especializou-se em radiotelegrafia estudando na Escola Técnica Federal em Curitiba, quando foi servir o exército. Voltou para Joinville e empregou-se na concessionária de energia elétrica Empresul. Mas é em Jaraguá do Sul que ele vai iniciar o seu próprio negócio com uma oficina de prestação de serviço gerais em eletricidade.

O bancário tinha pai professor de história, autor de um livro sobre Jaraguá do Sul. De origem húngara por parte da mãe e por parte do pai açoriana. Entrou cedo na escola criada pelo próprio pai, aos 13 anos já trabalhava num cartório e aos 14 anos torna-se bancário. Passou quatorze anos trabalhando num banco onde assumiu vários cargos até tornar-se subgerente na agência de Guaramirim. Tornou-se sócio de uma firma especializada na fabricação de canos de escape para veículos em 1957, aos 28 anos. Em quatro anos de direção a firma aumentou de 8 para 150 trabalhadores. Mas, em 1961, ele desvinculou-se da firma para fundar essa empresa. Foi diretor ${ }^{19}$, conselheiro e presidente de várias entidades.

\footnotetext{
18 Optamos por não citar nomes.

19 Da Associação Comercial e Industrial de Jaraguá a conselhos e comissões de características nacional: Comissão Empresarial de Competitividade ou do Comitê Brasileiro de Qualidade e Produtividade. Foi diretor da Federação das Indústria do Estado de São Paulo e da Associação Brasileira da Indústria Eletro-Eletrônica. Faz parte ainda do conselho das seguintes empresas: Oxford, Perdigão, Tigre, Marisol e na multinacional Champion, Papel e Celulose, nestas trabalham 30 mil pessoas, reunidas faturam 2,5 bilhões de dólares (Ternes, 1997).
} 
O mecânico tinha pai alemão, que chegou da Alemanha em 1928 para juntar-se a outros irmãos que já estavam no Brasil no Vale do Itajaí. Seu avô era mecânico. Trabalhou em várias firmas até iniciar o seu próprio negócio em serviços mecânicos gerais em Joinville. Assumiu também vários cargos políticos, como vereador, deputado estadual e prefeito da cidade de Jaraguá do Sul

Assim, se um deles possuía uma oficina e era um apaixonado por tudo que dissesse respeito à eletricidade, o outro tinha experiência administrativa como auxiliar de cartório e depois, como subgerente de um banco. Eles moravam em Jaraguá do Sul e chegaram à conclusão que era viável construir motores elétricos para suprir necessidades dos moradores da cidade que deles dependiam. Em termos técnicos nenhum dos dois outros sócios detinham conhecimentos sobre mecânica na década de 1960. Porém, o sócio bancário conhecia um excelente mecânico na cidade de Joinville e convenceu seu parceiro eletricista sobre a necessidade de incluir na sociedade um mecânico competente. Naquele tempo, segundo Ternes (1997), os motores elétricos vindos de outros lugares demoravam entre 40 e 60 dias para chegarem à cidade de Jaraguá do Sul.

Os sócios tinham muitos desafios a enfrentar. Dentre eles, a falta de uma força de trabalho qualificada, de maiores recursos financeiros e a ausência de uma tradição industrial em Jaraguá do Sul. Mas, os três sócios não desistiram e alugam um imóvel para deflagrar o processo produtivo. Sob o lema trabalho e disciplina, eles dão início à construção do primeiro motor, fabricado por eles mesmos. No primeiro ano de existência da empresa eles produziram 146 motores e um dos sócios é encarregado de promover vendas fora de Jaraguá do Sul.

Todavia, apesar da imensa boa vontade dos sócios, o empreendimento emperrava por problema de ordem técnica. Eles solucionaram o problema com o mecânico empregandose numa fábrica de motores em São Paulo. O emprego permitiu o sócio mecânico conhecer a tecnologia existente na fabricação de motores. Algum tempo depois ele regressou a Jaraguá do Sul com mais experiência e domínio técnico.

A compra do terreno para a sede própria da empresa é efetivada já em 1964. Tudo era planejado e organizado para que não fosse perdido nenhum dia de trabalho face à grande demanda de suas mercadorias. Nos primeiros cinco anos de existência da empresa (19611965), a produção de motores aumentou aproximadamente 64 vezes, isto é, de 149 a 9.486 
unidades. Nesse mesmo período, a força de trabalho aumentou apenas em 9 vezes, uma vez que passa de 9 para 81 empregados, exposto na tabela abaixo.

TABELA 10 - Número de motores produzidos e número de empregados entre 1961/1965

\begin{tabular}{c|c|c}
\hline Ano & $\mathbf{N}^{\mathbf{0}}$ de Motores & $\mathbf{N}^{\mathbf{0}}$ de Empregados \\
\hline 61 & 146 & 9 \\
\hline 62 & 4085 & 29 \\
\hline 63 & 6465 & 53 \\
\hline 64 & 7968 & 73 \\
\hline 65 & 9486 & 81 \\
\hline
\end{tabular}

FONTE: Ternes, 1997, p.38 e 40.

No dia $1^{\circ}$ de maio de 1965 , os sócios da empresa propõem a criação de uma associação recreativa para ser utilizada pelos trabalhadores, em consonância com a concepção de empresa familiar.

Nesse mesmo ano, a empresa lança ações no mercado. Com isso, transforma-se em uma sociedade anônima. Como sociedade anônima, a empresa produz 9 mil motores por ano; e, de 1965 a 1975, sua taxa média anual de crescimento é de $37 \%$ ao ano, enquanto nacionalmente o produto interno bruto cresce apenas $10 \%$, durante o período do chamado milagre econômico (Ternes, 1997, p. 46).

Nessa década (1966-1975), a empresa expande e eleva o número de sua força de trabalho de 117 para 1.552. Cresce assim 13 vezes, conforme podemos ver na tabela a seguir:

TABELA 11 - Número de motores produzidos e número de empregados entre 1966/1975

\begin{tabular}{c|c|c}
\hline Ano & $\mathbf{N}^{\mathbf{0}}$ de Motores & $\mathbf{N}^{\mathbf{0}}$ de Empregados \\
\hline 66 & 12987 & 117 \\
\hline 67 & 16595 & 152 \\
\hline 68 & 27817 & 225 \\
\hline 69 & 37319 & 336 \\
\hline 70 & 45560 & 409 \\
\hline 71 & 62772 & 496 \\
\hline 72 & 104134 & 830 \\
\hline 73 & 162225 & 1326 \\
\hline 74 & 272467 & 1461 \\
\hline 75 & 308345 & 1552 \\
\hline
\end{tabular}

FONTE: Ternes, 1997, p.80 e 86. 
Do ponto de vista do produto principal podemos constatar que a empresa se supera muitas vezes. Se em 1966 produz 12.977 motores, em 1975 a produção alcança o número de 308.345 peças, quer dizer, aumenta 23 vezes a sua produção em 10 anos. ( p. 80). Nesse momento, a empresa atravessa momentos de grande transformação, funda um Centro de Treinamento para capacitação profissional e busca no exterior suporte para emprego de tecnologia avançada. A indústria incrementa relações especiais com centros de pesquisa de unidades nacionais e internacionais e mantém programas de treinamento para seus engenheiros e pesquisadores no Brasil e no exterior. Vários técnicos vão para a Alemanha. A empresa também estreita relações com os Departamentos de Engenharia da Universidade Federal de Santa Catarina e a Escola Técnica Federal de Santa Catarina. De acordo com o depoimento de um de seus fundadores e presidente da empresa, a qualificação de seus trabalhadores (colaboradores) ${ }^{20}$ torna-se um dos pontos fundamentais de apoio.

Entre 1977 e 1986, a empresa enfrenta um período de crise de vendas provenientes não exatamente de razões de ordem interna da empresa, mas da economia brasileira. Ainda assim, a produção de motores cresce muito nessa década, passa de 325.979 para 1 1.361. 472 unidades, o que representa aumento de 4 vezes. A força de trabalho, em igual período, cresce quase na mesma proporção, 3,78 vezes; porém, entre os anos 1982 e 1984, acontece um decréscimo de vendas ocasionando demissões.

TABELA 12 - Número de motores produzidos e número de empregados entre 1976/1986

\begin{tabular}{c|c|c}
\hline Ano & $\mathbf{N}^{\mathbf{0}}$ de Motores & $\mathbf{N}^{\mathbf{0}}$ de Empregados \\
\hline 76 & 325979 & 1613 \\
\hline 77 & 458437 & 1935 \\
\hline 78 & 631536 & 2219 \\
\hline 79 & 845178 & 2867 \\
\hline 80 & 971114 & 3542 \\
\hline 81 & 993556 & 3949 \\
\hline 82 & 690801 & 3506 \\
\hline 83 & 620771 & 3290 \\
\hline 84 & 855557 & 3943 \\
\hline 85 & 1034879 & 4918 \\
\hline 86 & 1361472 & 6100 \\
\hline
\end{tabular}

FONTE: Ternes, 1997, p.122.

\footnotetext{
${ }^{20}$ Nessa empresa eles denominam os trabalhadores de colaboradores.
} 
A seguir a empresa direciona-se à diversificação ${ }^{21}$ de sua produção e, em fins de 1979, investe no setor eletro eletrônico e químico, quando implementa tecnologia na área de eletrônica de potência e de produção de tintas e vernizes, entre outros.

A crise por ela enfrentada nas décadas de 1980 e 1990, quando se viu obrigada a dispensar trabalhadores impulsiona-a a continuar na conquista de outros mercados.

Aparentemente, essa empresa faz parte de um conjunto, como se constituísse unicamente de capital nacional, muito embora seja possível reconhecer em suas entranhas a presença, desde a sua origem, de elementos internacionais, tais como: a tecnologia e, no limite, a força de trabalho. Possui escritórios de representação em quase todos os países do mundo. É a primeira na América Latina a buscar certificação de qualidade internacional para seus produtos. Possui filiais de vendas e de assistência técnica no exterior, localizadas na Austrália, nos Estados Unidos, na Argentina, na Bélgica, na Inglaterra, na Alemanha, na Espanha, no Japão, na Suécia, França e México, como podemos depreender do depoimento do gerente da Fábrica $\mathrm{X}$ a seguir:

Vou te mostrar uma coisa. Os produtos desta fábrica estão em vários países, apenas
$30 \%$ deles ficam no mercado interno, $70 \%$ vão para o mundo. A empresa hoje está
espalhada mundialmente. Acabamos de comprar uma Fábrica no México, duas
fábricas na Argentina. Temos escritórios nos Estados Unidos, México, Canadá,
Europa, África, Austrália, Nova Zelândia. Estamos espalhados no mundo. Temos

21 A[...] acionamentos surge em 1980,dedica-se à fabricação de componentes eletro-eletrônicos e promove a engenharia de aplicação para sistemas industriais. Atua no campo da informática industrial desenvolvendo controladores programáveis que se destinam ao comando e controle de processos industriais. A [...] máquinas , produz máquinas elétricas girantes para atender a um novo ramo de mercado, na mineração, petroquímica, celulose, papel e outros. São máquinas de grande porte, de corrente contínua, com altura de eixo de até $710 \mathrm{~mm}$, alternadores ou máquinas sincrônicas. Atua na área da eletrônica de potência. A empresa adquire o controle acionário integral da Ecemic Indústria de Transformadores e muda a razão social para [...]transformadores. Fornece pacotes integrados de produtos e serviços. Fabrica equipamentos de distribuição, atende a uma diversificada linha de necessidades em complexos industriais, concessionárias de energia elétrica, empresa de eletrificação rural, hospitais, conjuntos residenciais e comerciais, hotéis, construção civis e obras públicas. A [...] motores , produz os tradicionais motores elétricos, monofásicos e trifásicos, em três parques fabris. Já em 1984 consolida seu processo de verticalização de produção, em outras áreas. Com a compra de uma fábrica de tintas a Tintas Michigan S/A, esta é transformada em [...] química. Fabrica tintas para fins industriais e eletroisolamento. Processa resina de pinus illiottii, provenientes das suas próprias reservas florestais, dela resulta o breu e seus derivados, na terebintina e no óleo de pinho, aplicáveis em diferentes ramos industriais. Ela também comprou uma empresa no setor da pesca, porém não deu continuidade aos negócios. Este setor foi vendido. A [...] florestal utiliza incentivos fiscais do governo para a área do reflorestamento. Esta empresa detém 4.500 ha, com mais de 10 milhões de árvores. Situa-se como $4^{\mathrm{a}}$ empresa de SC e a $13^{\mathrm{a}}$ no Sul do Brasil. Esta, tem autonomia para atender durante cem anos o autoabastecimento do grupo. Atua na área da piscicultura e pecuária. (Ternes, 1997, p. 112,113,115). 
quatro postos nos Estados Unidos e também em Buenos Aires, Europa, Bélgica, Inglaterra, Alemanha, Espanha, Japão, Escandinávia. No México nós temos, além de escritório, uma fábrica de motores. Chegamos à França, embora estejamos em Jaraguá do Sul, mas a nossa missão é grande (Anexo, 1).

Hoje, a empresa retorna como líder na fabricação de motores elétricos uma vez que desde o início da década de noventa reorientou a produção para os motores elétricos que se encontrava diversificada em outros ramos. Esse redirecionamento é uma volta às origens, centralizando a sua produção novamente no seu primeiro produto. Ela tem por objetivo, até o ano de 2007, despontar entre as maiores fabricantes de motores elétricos do mundo, de acordo com o depoimento do Gerente da Fábrica X (Anexo 1).

De acordo com os dados disponíveis, em 1996, emprega, em Jaraguá do Sul e municípios vizinhos, 7.773 trabalhadores. Quase todo o parque fabril dessa empresa localizase no vale do Itapocu. Dois de seus parques fabris, o I e o II, situam-se na cidade de Jaraguá do Sul. O parque fabril III, em Guaramirim, e o Parque Fabril IV, em Blumenau. Além desses, a empresa possui uma unidade no Estado de São Paulo, em Guarulhos (UG) e uma unidade na Argentina (MORBE). Recentemente, comprou uma empresa no México.

\title{
1.3.1 Trabalho, Tecnologia Avançada E A Reestruturação Produtiva dos Anos SETENTA
}

\begin{abstract}
$\mathrm{Na}$ cronologia da empresa-líder muito antes das transformações da economia brasileira decorrentes da abertura de mercado no início da década de 1990, pode-se verificar que a qualidade, a produtividade, a pesquisa tecnológica e a qualificação dos colaboradores - valores que só passaram a merecer atenção no cenário brasileiro nos últimos anos - sempre estiveram presentes. Uma das explicações é que grande parte desses valores decorrem dos princípios de vida dos fundadores da empresa, todos impregnados de valores da cultura germânica, presentes de forma excepcional na formação psicológica, ética e profissional dos três fundadores, todos nascidos e criados na geografia européia do norte catarinense, a partir da década de 1930 (Ternes, 1997, p. 36).
\end{abstract}

Após um longo período de desenvolvimento industrial, por meio do processo de substituição de importações e de integração da economia brasileira ao mercado internacional, as indústrias nacionais passam por um momento de ruptura a partir da metade dos anos setenta. As empresas são obrigadas a reestruturarem-se no plano organizacional e financeiro, com repercussões sobre a força de trabalho. 
O sul repercute como região ganhadora nesse rearranjo industrial no Brasil, pois aumenta, entre 1970 e 1990, o número de estabelecimentos (de 14.534 para 43.969), o número de pessoal ocupado (de 358.100 para 2.520.493) e o valor da transformação industrial (de 1.343.666.303 dólares para 15.299.863.312 dólares). Em 1970, enquanto essa região acolhia apenas 14,79\% do pessoal ocupado do país, São Paulo concentrava 50,97\%. Vinte anos depois, São Paulo reunia 35,35\% do emprego industrial e a região Sul, que já havia ultrapassado esse umbral, ostentava $36,49 \%$ do total nacional (Santos \& Silveira, 2001, p. 107).

A entrada dessa empresa mais cedo no mercado internacional em relação as outras indústrias nacionais, parece ser fruto da herança germânica, não por determinação genética, mas por terem os três sócios da empresa, logo no início desse empreendimento, ido para a Alemanha em busca de tecnologia. A Alemanha da década de 1970, época dos primeiros contatos, já dispunha de formas de organização de trabalho correspondentes ao próprio desenvolvimento capitalista ao qual estava submetida, e ainda em recuperação dos destroços da segunda Guerra mundial (1939-45).

A empresa analisada, desde os anos setenta, segundo Ternes (1997) promove a cidade e hoje ocupa um relevante lugar em produção industrial no Estado de Santa Catarina, sendo responsável pelos principais produtos de exportação deste Estado.

O principal produto exportado pela indústria catarinense vem do ramo metalmecânico: os motocompressores, que significam, sozinhos, $9 \%$ do total exportado pela indústria catarinense em 1995. O setor metal-mecânico é tão importante que, em 1995, ele foi responsável por 40,66\% de todo o IPI (Imposto sobre Produtos Industrializados) arrecadado em Santa Catarina (DIEESE, 1996, p. 111).

Segundo estudo do DIEESE (1996), no período compreendido entre 1994 e 1996, a reestruturação do modelo de produção no setor metal-mecânico assegurou um crescimento de produtividade em torno de $99 \%$.

Esta informação, que se refere à produtividade física, isto é, produção sobre homens/hora, supera em muito os dados oficiais sobre aumento médio da produtividade na indústria de transformação no Brasil, pois já é o mais elevado do mundo. A confrontação desta informação com outras referentes à redução de pessoal, redução de indicadores, redução do custo da folha e aumento da intensidade de trabalho, remete-nos a uma constatação: os ganhos de produtividade têm se baseado principalmente através de uma brutal sobrecarga dos trabalhadores ( $\mathrm{p} \mathrm{.95).}$

Porém, para a empresa selecionada, a contingência histórica de implementação tecnológica não se apresentou como uma imposição conjuntural da denominada 
reestruturação produtiva, mais evidente no Brasil na década de 90, pois desde os primeiros momentos da produção de motores elétricos, o primeiro problema desabrochado nesse processo de trabalho foi de origem técnica e, a partir de sua solução, os sócios não pararam mais de preocupar-se e investir esforços no sentido de atualização, implementação e produção dos seus motores com tecnologias avançadas. Aliado a esse desafio inicial, e concomitantemente, eles ingressam com esses produtos no mercado internacional, desde o início da década de 1970, do século passado, mesmo que timidamente.

\begin{abstract}
Assim, os produtos da indústria pesquisada são fabricados com a combinação de emprego de força de trabalho motivada e tecnologia avançada. Desde os primórdios que os fundadores da empresa viajam para São Paulo e depois para o exterior, especificamente para a Alemanha, em busca de tecnologia, máquinas e ferramentas para a fabricação de motores, isso tudo de acordo com as normas métricas da International Eletric Commission (IEC). A viagem para Alemanha, realizada em 1968, marca o início do estabelecimento de condições para competirem mundialmente (Quadros, 1993, p. 30).
\end{abstract}

A ampliação do seu parque fabril aconteceu a partir da década de 1980 e a produção extrapola a de motores elétricos. Inicia nessa época a sua diversificação de produção, como já anunciamos acima, incluindo os componentes eletro-eletrônicos, produtos para automação industrial, transformadores de força e distribuição, tintas líquidas e em pó, vernizes eletroisolantes; consolidando-se, nessa época, como fornecedora de sistemas elétricos industriais completos. Mas, nas últimas décadas do século passado, a ênfase é retomada na produção de motores elétricos industriais

Nessa época, eles se armaram dos componentes básicos dos quais as empresas lançam mão atualmente para a derrubada mundial das fronteiras comerciais. Busca das últimas tecnologias e equipamentos na fonte, conhecimento de como o concorrente faz o mesmo produto e certificações chaves que a habilitam a operar no mercado internacional, a [...] em 1970 [...] já exportava, embora timidamente (Quadros, 1993, p. 30). Grifos nossos.

De acordo com informações da Revista ${ }^{22}$ Expressão, nos últimos cinco anos do século passado, a empresa aplicou 200 milhões de reais em tecnologia para modernização de seu parque fabril e melhoria dos processos de produção e também monta uma fábrica de motores elétricos para eletrodomésticos, colocando-se na disputa de mais essa fatia de mercado. Os motores elétricos que fabrica estão direcionados para Indústrias. Porém, a

\footnotetext{
${ }^{22}$ A Revista Expressão é uma revista regional de economia; considerada, por seus pares, como um dos principais veículos desse tipo na Região Sul do Brasil.
} 
preocupação com tecnologia não é recente. O presidente da Empresa, afirma, nessa entrevista, que eles enfrentam o mercado internacional sem perder de vista a atualização tecnológica:

[...] sempre tivemos uma cultura tecnológica muito forte. Hoje, temos uma rede de consultores mundiais e estamos ligados com várias universidades e centros de pesquisa no Brasil e no exterior, que desenvolvem projetos em conjunto, simultaneamente. Também criamos, uns três anos atrás, um comitê científico tecnológico formado por quatro dos principais executivos da área tecnológica e cinco professores - da Europa, dos Estados Unidos e do Brasil -, todos doutores e de grande reconhecimento nas áreas de máquinas eletrodinâmicas e de eletrônica de potência. Eles se reúnem duas vezes por ano para traçar as grandes linhas de desenvolvimento futuro da empresa além, é claro, de resolver problemas tecnológicos de aplicação imediata (Lucas, 2000, p. 14).

O fato é que não basta ter trabalhadores qualificados. Os meios produtivos, ao que parece, incorporam cada vez mais avanços tecnológicos. Ao contrário de sociedades anteriores a essa, os instrumentos de trabalho adquirem habilidades e podem produzir riquezas de modo eficiente e em escala jamais vista. Por conseguinte, a empresa organiza e reorganiza seu processo de trabalho sem cessar. A garantia de custos baixos e de excelente qualidade de seus produtos pressupõe, contrariamente ao que afirma Ternes (1997), mudanças muito distintas daquelas da época de fundação da empresa.

Vale ressaltar o que Shumpeter $(1982)^{23}$ explica: o movimento econômico, como situações passageiras, resulta num processo permanente de criação-inovação. Ele se desenvolve em ondas sucessivas e vem acompanhado de incessante elevação do nível de vida. A história do processo de trabalho é também a história constante de superações do obsoleto por meio do progresso técnico aumentando a produtividade.

O produtor econômico é, na verdade, um eterno inovador, no sentido de criação de novos mercados. Por essas necessidades, de constantes mudanças, esses produtores tornam-se empreendedores inovadores.

$\mathrm{Na}$ vida econômica deve-se agir sem resolver todos os detalhes do que deve ser feito. Aqui o sucesso depende da intuição, da capacidade de ver as coisas de uma maneira que posteriormente se constata ser verdadeira, mesmo que, no momento, isso não possa ser comprovado, e de se perceber o fato essencial, deixando de lado o perfunctório, mesmo que não possa demonstrar os princípios que nortearam a ação. ${ }^{24}$

\footnotetext{
${ }^{23}$ Shumpeter, J.A. Teoria do Desenvolvimento Econômico. São Paulo: Abril Cultural, 1982.

${ }^{24}$ Idem Op cit. p. 12.
} 
A noção de empreendedor inovador está presente no imaginário social, possibilitando a explicação do sucesso fabril a partir de características psicológicas individuais. No caso especial da empresa analisada, tais formulações aliam-se aos dos aspectos culturais europeus, presentes no norte do Estado de Santa Catarina. Esse conjunto de fatores vem explicando as condições para o desenvolvimento industrial como se a constituição de um empresário dependesse unicamente de aspectos psicológicos.

É certo que características individuais sempre foram e são importantes em empreendimentos humanos, mas elas por si só não constituem os pressupostos necessários ao sucesso empresarial. Assim, dentre os fatores oriundos do conjunto das relações sociais, destacamos, nessa empresa, a valorização de tecnologias avançadas como solução para uma maior produtividade com baixo custo, a qual é priorizada ininterruptamente, bem como uma atenção central dirigida na assimilação da cultura da empresa pelos trabalhadores.

\title{
1.4 A Cultura da empresa e O Processo de Organização do Trabalho
}

A organização do processo interno de trabalho dessa empresa, para o gerente geral da Fábrica X, é sui generis, ela

\begin{abstract}
[...] vai nascendo com a peculiaridade própria da sociedade brasileira. Porque, esse jeitinho do cara sair daqui, ir lá fora conhecer e trabalhar para captar o conhecimento é coisa de brasileiro. Se você olhar a vida, ela funciona como um ascenóide: os 7 anos de vacas magras sempre são seguidos de 7 anos de vacas gordas e assim segue a vida. Grosseiramente, é isso que acontece dentro da empresa. No período em que existe crise compramos máquinas, preparamos pessoal. No período de ascensão da produção, máquinas e trabalhadores estão preparados e é só subir a ladeira. Quando se chega lá em cima, os outros estão recém começando, quem se preparou vai ganhando o mercado. A indústria cresceu muito com isso e com essa mentalidade. Quando está em baixa é hora de investir, quando está subindo é hora de só ganhar. É o que está acontecendo agora na Fábrica (Anexo,1).
\end{abstract}

A empresa, sempre em expansão, tem por base alguns princípios de organização de seu processo interno de trabalho ou uma filosofia denominada habitualmente como cultura da empresa. Segundo dados disponibilizados, as principais decisões tomadas pelos administradores dela seguem princípios já citados anteriormente. 
Os princípios ${ }^{25}$ também são apresentados em doze itens: 1. Princípios das mudanças e atualizações; 2. Princípios de Marketing; 3. Princípios sobre o lucro; 4. Princípios sobre fornecedores; 5. Princípios sobre recursos humanos; 6. Princípios de qualidade; 7. Princípios sobre produtos; 8. Princípios sobre canais de distribuição e prestação de serviços pós-venda; 9. Princípios sobre ambiente; 10. Princípios sobre tecnologia; 12. Princípios sobre acionistas; 13. Princípios sobre finanças.

A estrutura básica geral de administração dessa empresa é relativamente simples. Constitui-se de um conselho de administração, com presidente e vice-presidentes, uma diretoria geral (com diretor- presidente, diretor de marketing, diretor administrativo e diretor técnico), várias diretorias para cada fábrica de seus parques industriais, gerências para cada uma delas e departamentos, seções e os trabalhadores do chão da Fábrica. A hierarquia funcional fundamenta-se numa avaliação e no desempenho do empregado. Os salários $^{26}$ são distribuídos de acordo com os diferentes postos e qualificações que são ocupados pelos trabalhadores. Possui um centro administrativo, inaugurado em 1985, numa área de 5 mil metros quadrados, com auditório, centro de processamento de dados, vários departamentos, museu do motor e um show room dos seus produtos. Os parques industriais estão mobilizados no sentido de produzir 5 milhões de motores elétricos por ano.

De acordo com os fundadores, e mesmo os descendentes, proprietários da empresa, os trabalhadores precisam se sentir parte do negócio, como se eles formassem uma grande família. Nas palavras de um dos seus fundadores: ..."quando faltam máquinas, você as pode comprar, se não tiver dinheiro, pode pedir emprestado: mas homens você não pode comprar ou pedir emprestado, e homens motivados por uma idéia são a base do êxito" (Ternes, 1997, p. 3).

Essa é a síntese maior em que se baseiam para a efetivação do princípio da valorização do ser humano.

\footnotetext{
${ }^{25}$ Em praticamente todas as publicações da empresa, esses princípios estão expostos.

26 Não conseguimos informação precisa sobre a média salarial da Fábrica X. Nem o gerente respondeu quando perguntado sobre esta questão, nem os próprios trabalhadores.
} 
A empresa possui vasto marketing ${ }^{27}$ em que expõe seus princípios norteadores de modo a atingir o maior número possível de pessoas dentro e fora de sua esfera ${ }^{28}$. Utiliza freqüentemente os recursos da imprensa escrita, falada e televisiva, assim como se 'serve' da representação em órgãos públicos. O sócio mecânico, de 1989 a 1996, é vereador, deputado estadual e torna-se prefeito de Jaraguá do Sul, com mandato ${ }^{29}$ até o ano 2000. A tese da unidade entre a fábrica e a cidade confirma-se na dialética contraditória do privado e do público.

Desse modo, a filosofia passa a ser a mesma, tanto na empresa como na cidade: na primeira, trabalho, trabalho e trabalho e na segunda grandeza pelo trabalho. Todos são valorizados pelo trabalho: o homem (a força de trabalho), os clientes e os fornecedores, ou melhor, todos que trabalham. Os princípios que são difundidos pela empresa configuram, dinamizam e orientam o processo de trabalho.

Esses princípios, por exemplo, entendem que mudança e atualização constantes supõem futuro em movimento. A obsolescência, portanto, resulta da velocidade das transformações. Desse modo, uma certa fábrica só pode sobreviver caso controle as mudanças ao invés de ser por elas controlada. De acordo com tal formulação, de nada vale uma idéia brilhante, se ela não for acompanhada de uma ação sólida e objetiva que a torne uma realidade.

Essa empresa tem por meta, no tocante aos seus recursos humanos promover a integração e o treinamento, disponibilizar ambientes de trabalho seguros e saudáveis, assistência complementar médico-odontológica, alimentação, serviço social, acesso a práticas esportivas (lazer?), e oportunidade de ascensão profissional com sistemática avaliação de desempenho. Por esses princípios, uma administração participativa será praticada por meio de, círculos de qualidade, grupos de análise de valores, comissões, grupos de trabalho e reuniões. Os cargos serão descritos e a avaliados cientificamente e, pelo desempenho do trabalhador, terão a remuneração justa.

\footnotetext{
${ }^{27}$ Vimos nas palavras do Presidente da empresa que a preocupação com a propaganda é um dos pilares de sua administração e sustenta também o sucesso da empresa.

${ }^{28}$ Os trabalhadores são denominados colaboradores, dos gerentes ao funileiro.

${ }^{29}$ Ele não completou o mandato de prefeito por ter falecido em acidente automobilístico em 09 de fevereiro de 1999.
} 
O atual presidente da empresa pesquisada, um dos herdeiros, sócio da empresa, é muitas vezes lembrado que nela iniciou trabalhando como técnico. Essa trajetória é difundida como um exemplo a ser seguido por todos aqueles que desejam ascender socialmente. Contudo, ele é o primeiro e único trabalhador, ao longo da existência dessa fábrica, que consegue obter o cargo de presidente.

Essa oportunidade de ascensão profissional, segundo dados fornecidos pelos gerentes, é realizada por meio de uma avaliação sistemática de desempenho; nesse sentido, constatamos que é a partir dessa ascensão que as diferenças salariais entre os trabalhadores tornam-se presentes. Percebemos que essa situação pode ser a responsável pelo 'segredo' em volta da faixa salarial desses trabalhadores, pois não conseguimos desvendá-la. Em entrevista realizada com um deles, após longo diálogo, tentamos obter essa informação, e, mesmo numa situação em que ele não estava identificado, ainda assim, ele não respondeu. Fizemos afirmações objetivas apresentando possíveis faixas salariais, mas não houve exatidão nas respostas. Tentamos com o gerente da Fábrica X e a condução foi a mesma, o máximo que ele respondeu foi que estava satisfeito com a remuneração recebida (Anexo,1).

Mas, esses princípios estão de alguma forma expressos nas normas de comportamento que o trabalhador deve seguir e encontram-se descritos no Manual do Colaborador (Anexo 7). Nesse manual constam deveres e as vantagens de pertencer à empresa. Para isso, é mister ser um colaborador ativo e assimilar o pressuposto de que não basta só trabalhar, mas é preciso trabalhar ${ }^{30}$ com o máximo de empenho.

O Manual do colaborador explicita a lógica dessa organização: atribui aos trabalhadores responsabilidade na qualidade das mercadorias produzidas. Em síntese, o trabalhador é o próprio inspetor de qualidade do seu trabalho. Acidentes, faltas e desperdícios são problemas que devem ser equacionados por eles. Outra orientação é que jamais devem realizar alguma atividade produtiva com dúvida; devem aprender e se habituar a fazer certo, desde a primeira vez, pois, quanto mais os clientes estiverem satisfeitos com os produtos bem feitos (leia-se qualidade final excelente), mais vendas ocorrerão e, ao aumentar a produção, conseqüentemente, haverá dinheiro no bolso de todos. Essas explicações permeiam os

\footnotetext{
${ }^{30}$ Fazer greve pode significar justamente a falta de vontade de se trabalhar, sendo que para a cidade de Jaraguá do Sul, que é grande pelo trabalho, quem não trabalhar, mesmo numa greve, poderá estar fadado a ser
} 
pressupostos do manual, bem como estão também assimiladas por eles, que afirmam que dessa maneira todos ganham, até os trabalhadores, pois têm participação nos lucros (recebem 16 salários anuais, de acordo com a filosofia dessa empresa) e então sentem, na prática, a efetivação desse princípio. Aí se percebe uma identificação com a fábrica ideal de Adam Smith (1723-1790), pois segundo esse autor, quanto mais se trabalha mais a nação e todos ganham $^{31}$.

Os trabalhadores da Fábrica X têm vários benefícios sociais indiretos, tais como assistência social, auxílio doença, auxílio odontológico e hospitalar, previdência social e programas de alimentação, treinamento e desenvolvimento, auxílio escolar e associação recreativa. Isso tudo promove um diferencial no status de ser trabalhador dessa empresa; trabalhar nela é o projeto de quase todo jovem na cidade, conforme depoimentos.

A condição material de vida pode ser evidenciada à medida que eles possuem também casa própria, carro e alguns passam férias (quando as têm) na praia.

Uma explicação para a consolidação desses princípios aliados ao sucesso da empresa é, segundo Ternes (1997), a motivação dos trabalhadores. Nessa perspectiva, ele reafirma a filosofia de seus fundadores "homens motivados por uma idéia são a base do êxito" (Ternes, 1997). Porém, se essa formulação encontrasse respaldo na história, os ancestrais da classe trabalhadora não teriam de ser submetidos a ferro e fogo ao trabalho assalariado. Essa condição histórica levou, no mínimo, três séculos para ser construída e supôs muita violência. O movimento luddista é um exemplar desse processo que expressou a revolta dos trabalhadores contra as máquinas que, a seu ver, jogavam homens na miséria.

A história dessa empresa evidencia que somente crescem e se perpetuam nessa sociedade as empresas altamente competitivas. Suas reorientações e suas ampliações seguem sempre esta lógica. Nesse caso foram fundamentais a concentração dos meios produtivos em parques fabris e a centralização de capitais, condições imprescindíveis para a sua continuidade no Brasil e fora dele.

considerado como um malfeitor à cidade. De fato, na história da empresa, são raras as manifestações grevistas. Há registro de uma única e mesmo assim, sem manisfestações fora dos escritórios.

31 O pai da economia política, Adam Smith, afirma ser uma 'mão invisível' a reguladora dos interesses individuais na busca de suas satisfações. Esse paradigma norteou a formulação teórica de todos os estudiosos da 


\subsubsection{SOBRE O MODELO DE ORGANIZAÇÃO INTERNA DO TRABALHO}

A organização do processo de trabalho no chão de $u_{m a}^{32}$ das fábricas do vasto parque industrial dessa empresa, mostrou-nos que nela não existem necessariamente, modelos definidos. Os elementos e princípios norteadores expressos pela chamada 'cultura da empresa' constituem um amálgama de características que perpassam pelo taylorismo- fordismo, como também pelo toyotismo, materializando-se numa prática produtiva 'híbrida', conforme Antunes (1995).

As características presentes na organização do trabalho dessa empresa mostram que é complexo falar, resguardando a realidade brasileira, em modelos puros de organização do trabalho do tipo taylorista-fordista ou mesmo do modelo conhecido como toyotista. Esse último, no final da década de 90 do século XX, ganha força em nosso país como alternativa de solução para o alcance de produtividade com baixo custo.

Essa forma de organização do trabalho denominada toyotismo começou a ser desenvolvida no Japão a partir dos anos 50. Segundo Antunes (1999), esse modelo foi gestado a partir da crise capitalista do esgotamento da produção da riqueza cuja base produtiva perdera competitividade. A produção de mercadorias próprias da era fordista entra em questão, uma vez que não consegue satisfazer as exigências continuadas da acumulação capitalista.

Segundo Zilbovicius (1993) o toyotismo não apresenta questões novas, mas resolve os velhos problemas de uma maneira nova (garantir o aumento de produtividade, qualidade com redução de custos) ${ }^{33}$.

economia política até a crise de 1929/1933, período que evidenciou a não veracidade desse paradigma. Aued, I. Teoria Econômica e reforma curricular. In: Textos de Economia. Florianópolis, junho de 1987, p. 14.

32 A nossa entrada no chão da fábrica aconteceu em apenas uma das fábricas, considerando que esta pode ser utilizada como exemplo, em relação às demais.

${ }^{33}$ Até os anos 70, quando o Japão produzia apenas para o mercado interno, era um país irrelevante e pouco se ouvia falar sobre ele. No entanto, a partir do momento em que começa a participar do mercado externo, passa a ser uma força, mais especificamente, quando entra no mercado americano, que era o coração da indústria automobilística mundial (Zilbovicius, 1993,p.12). 
O modelo do processo de trabalho dessa fábrica configura-se unido aos elementos da chamada cultura da empresa ${ }^{34}$, porém, ao considerar o modelo híbrido de organização do trabalho (Antunes, 1995, p.50) ${ }^{35}$, podemos afirmar que na realidade pesquisada há uma articulação de elementos de "continuidade e descontinuidade do padrão taylorista-fordista de acumulação".

Na opinião dos trabalhadores, o processo de organização do trabalho expressa-se na valorização das tecnologias (conhecimento científico), valorização do ser humano (homens motivados), valorização da formação constante de seus 'colaboradores' (incentivo à

\footnotetext{
${ }^{34} \mathrm{Na}$ realidade eles denominam em alguns momentos cultura da empresa e em outros cultura [...] ou seja, o nome da empresa é anexado à cultura; ficamos com cultura da empresa.

${ }^{35}$ Segundo Antunes (1999) o toyotismo diferencia-se do fordismo nos seguintes traços:1. é uma produção muito vinculada à demanda, visando atender às exigências mais individualizadas do mercado consumidor, diferenciando-se da produção em série e de massa do taylorismo/fordismo. Por isso sua produção é variada e bastante heterogênea, ao contrário da homogeneização fordista. 2. Fundamenta-se no trabalho operário em equipe, com multivariedade de funções, rompendo com o caráter parcelar típico do fordismo; 3 . A produção se estrutura num processo produtivo flexível, que possibilita ao operário operar simultaneamente várias máquinas [...] alterando-se a relação homem/máquina na qual se baseava o taylorismo/fordismo; 4 . Tem como princípio o just in time, o melhor aproveitamento possível do tempo de produção; 5. Funciona segundo o sistema Kanban, placas ou senhas de comando para reposição de peças e estoque. No toyotismo, os estoques são mínimos quando comparados ao fordismo; 6 . As empresas do complexo produtivo toyotista, inclusive as terceirizadas, têm uma estrutura horizontalizada, ao contrário da verticalidade fordista. Enquanto na fábrica fordista aproximadamente $75 \%$ da produção era realizada no seu interior, a fábricas toyotista é responsável por somente $25 \%$ da produção, tendência que vem se intensificando ainda mais. Essa última prioriza o que é central em sua especialidade no processo produtivo ( a chamada teoria do foco) e transfere a "terceiros" grande parte do que antes era produzido dentro de seu espaço produtivo. Essa horizontalização estende-se às subcontratadas, às firmas terceirizadas, acarretando a expansão dos métodos e procedimentos para toda a rede de fornecedores. Desse modo, flexibilização, terceirização, subcontratação, $\mathrm{CCQ}$, controle de qualidade total, kanban, jus in time, kaizen, team work,, eliminação do desperdício, "gerência participativa", sindicalismo de empresa, entre tantos outros pontos, são levados para um espaço ampliado do processo produtivo; 7. Organiza os Círculos de Controle de Qualidade (CCQs), constituindo grupos de trabalhadores que são instigados pelo capital a discutir seu trabalho e desempenho, com vistas a melhorar a produtividade das empresas, convertendo-se num importante instrumento para o capital apropriar-se do savoir faire intelectual e cognitivo do trabalho, que o fordismo desprezava; 8 . O toyotismo implantou o "emprego vitalício" para uma parcela dos trabalhadores das grandes empresas (cerca de 25 a $30 \%$ da população trabalhadora, onde se presenciava a exclusão das mulheres), além de ganhos salariais intimamente vinculados ao aumento da produtividade. O emprego vitalício garante ao trabalhador japonês que trabalha nas fábricas inseridas nesse modelo a estabilidade do emprego, sendo que aos 55 anos o trabalhador é deslocado para outro trabalho menos relevante, no complexo de atividades existentes na mesma empresa (p. $54 / 55)$.

${ }^{35} \mathrm{Na}$ verdade está escrito Manual do Colaborador, mas, o seu conteúdo exprime a melhor conduta que é esperada para os seus colaboradores; no Anexo 7 expomos uma síntese desse manual. O Manual do Colaborador, ou o que estamos entendendo como um código de ética, é distribuído no ato do contrato da pessoa com a empresa. Ao contratado é sugerido a recorrência ao manual, ou ao seu chefe, e jamais fazer algo quando estiver com dúvidas, isso para não comprometer a qualidade do produto; portanto, o controle é exercido pelo próprio trabalhador, e, como tal, internalizado. Acertar desde a primeira vez, essa é uma das normas primordiais no manual.
} 
capacitação), delimitados e enfatizados por meio de uma expectativa de conduta pessoal definida por um código de ética ${ }^{36}$.

No interior do processo de trabalho investigado, vimos que os trabalhadores do chão da fábrica são caracterizados como colaboradores, ou seja, temos impressão de que é o sujeito que define (por isso a responsabilidade pela fabricação dos excelentes motores) a realização das atividades, tal como propõe o toyotismo. O caráter participativo dessa atuação também supõe a presença deles nos CCQs (Círculos de Controle de Qualidade), grupos de análise de valores, comissões e grupos de trabalho. A administração participativa é realizada por meio de vários tipos de comissões, grupos e variadas reuniões. Uma particularidade descrita no Manual do Colaborador é que essas reuniões não podem ser consideradas como hora extra, apesar de se realizarem fora da jornada de trabalho. As decisões são sempre tomadas coletivamente e, para o gerente, tal prática é uma herança dos três sócios que fundaram a empresa. Ele explica como se dá esse processo:

\begin{abstract}
Por exemplo, se eu vou comprar máquinas, eu vou para uma comissão que tem gerente de Holding, mas tem gerentes de outras áreas que vão opinar sobre o assunto e discutir. Se eu vou tratar de recursos humanos, de doenças que estão sendo geradas no trabalho, eu vou ter um grupo com o pessoal da área médica, com o pessoal dos recursos humanos e outro da fábrica, com quem eu vou discutir. Se alguém diz: Olha, na minha fábrica estou fazendo a ginástica, quem sabe tu experimentas isso, ao invés de simplesmente encostar esse cara num canto. Boa idéia! Mas eu não posso fazer esse exercício assim, assado. Beleza, mas nós podemos fazer outro. E por aí vai se trocando as idéias e busca-se um consenso. Nós temos várias comissões ( Anexo 1).
\end{abstract}

A produtividade com qualidade, a busca constante de tecnologia de ponta, o reinvestimento do lucro na própria empresa e o ícone da administração disseminado como de valorização do ser humano, compõem os elementos principais desse processo. Dessa forma, parece-nos que aqui, como na Europa, os trabalhadores em condições mais favoráveis do que o restante do país, pensam que se tentar melhorar pode até estragar, palavras de um trabalhador entrevistado (Anexo 6).

Essas características que determinam o comportamento do trabalhador estão também presentes, ou melhor, conectadas à cultura regional herdada e construída pelos imigrantes vindos da Europa. A disciplina (comportamento adequado), a qualificação 
educacional, o desempenho eficiente (trabalhar sem erros), a obediência às regras e a motivação constituem elementos que conformam o trabalhador ideal nessa indústria. A opinião pública local, conforme a maioria dos depoimentos, também entende que esses elementos de conduta é que fazem a empresa ser bem sucedida tanto no mercado nacional como no internacional.

A indústria possui algumas particularidades que contribuem para o fortalecimento de sua imagem já que de um galpão alugado se transforma na quinta fabricante de motores elétricos do mundo. Sua consolidação é explicada como fruto da disciplina, do trabalho e da ousadia de seus sócios-proprietários (Ternes, 1997).

Por outro lado, tais formulações confirmam uma concepção de naturalidade do assalariamento. Os indivíduos nesta sociedade, afirma Heller (1991), não conseguem desvendar a dupla natureza do trabalho que é, a um só tempo, produção de coisas úteis e valorização do capital. Nesse sentido, o trabalho realizado na fábrica aparece e é evidenciado somente no aspecto de se produzir para satisfazer necessidades humanas - o trabalho para si, o outro aspecto, cujo destino seria o de se produzir para o outro, fica camuflado.

Assim, nessa empresa, os trabalhadores compreendem que produtividade, de modo geral, é uma exigência parecida com as da vida familiar e não como domínio de uns homens sobre outros. Para os trabalhadores, o crescimento da empresa depende de sua eficiência e produtividade; na mesma medida, entendem que são elas que garantem seu emprego.

Eles assimilam bem a necessidade de a empresa produzir bastante e com eficiência. Em uma entrevista realizada com um trabalhador, perguntamos: qual sua reação e a de seus colegas diante da diminuição das últimas férias para quinze dias, no último verão, ao que ele respondeu: tem que se conformar. Perguntamos o porquê, ele diz: é necessário (Anexo 6).

No ambiente de trabalho da Fábrica $X$, vimos que a disciplina, a obediência às normas gerais de conduta (que está escrita no Manual do Colaborador) e o empenho em produzir seguindo as normas técnicas (padrões nacionais e internacionais) por todos os 
trabalhadores é perceptível, todos trabalham ininterruptamente. Só param a produção no momento da ginástica. Eles vivem, praticamente, só trabalhando

Porém, eles aparentavam estar satisfeitos, segundo resposta de um trabalhador entrevistado, quando perguntado sobre porque tinha satisfação em seu trabalho, ele respondeu: A [...] nunca foi de dar aumento abaixo da inflação, ou pelo menos na inflação, nunca deixou de olhar para o colaborador, tem também a divisão de lucros. A sensação de segurança aliada a essas condições e a garantia de emprego, bem como a estabilidade nele, fazem crer que a eficiência no trabalho garante um retorno individual. $\mathrm{O}$ maior elogio que esse trabalhador podia fazer à empresa era dizer que ela representava, para ele, solidez. Perguntamos o que isso significava, ele respondeu: é uma empresa bem sólida.

Esse mesmo trabalhador também já participou de um curso de reciclagem na Alemanha. Ele é descendente de alemães e avalia que tal oportunidade somente ocorre nessa empresa e que apenas ela pode proporcionar tamanho incentivo. Este fato, dentre muitos outros, consolida a idéia de que essa empresa protege seus trabalhadores porque funciona como se fosse uma família e acima de tudo valoriza o ser humano.

Numa entrevista com um trabalhador formado na escola da empresa, a análise recaiu no incentivo aos estudos, sendo outro componente que expressava, para ele, a valorização do ser humano. A empresa paga para a pessoa só estudar.

Estudando, só estudando, meio período. Aí, depois, mais um ano tu avanças no estágio, depois faz mecânica, depois faz eletricidade, depois faz eletrônica... Eu estudei em 1981. Aí faz o curso e tu vais ganhando mais um pouquinho, só que tem médico, dentista, almoço, vira um empregado normal, só que você está estudando (Anexo 6).

As entrevistas revelaram também que, para os trabalhadores, o trabalho, a disciplina, a seriedade, o empenho e a ousadia dos três fundadores foram o que conferiu o espírito de crescimento ininterrupto à empresa. Porém, percebemos que a exaltação aos feitos individuais ignora muitas vezes que é o trabalho coletivo que faz crescer a produção da riqueza, no modo de vida capitalista. Assim, o crescimento dessa indústria é visto como o resultado de iniciativas particulares, como se elas pudessem, num passe de mágica, fazer brotar riquezas inimagináveis. 
Nesta Fábrica ${ }^{37}$ a implementação tecnológica acontece, porém, disse o gerente: apesar desta fábrica se atualizar, ela exige para as tarefas ali realizadas, um maior esforço humano devido à montagem de motores que não é de fato automatizada, mas manual, o que exige força, concentração e outras habilidades bem mais motoras ${ }^{38}$ (Anexo, 1).

Nela, só encontramos uma máquina com comando numérico computadorizado. Por sinal, em uma visita, ao observarmos um trabalhador operando-a, perguntamos: antes da existência dessa máquina, eram necessários quantos trabalhadores para fazer essa mesma tarefa? Segundo ele eram quatro; continuamos perguntando: onde eles estão agora? Ele respondeu: foram remanejados. Nessa empresa, segundo outros depoimentos, os trabalhadores não estão sendo desempregados ${ }^{39}$, mas sendo aproveitados em outras seções. Explicam desse modo, a exigência da continuidade dos estudos.

Existe também a prática de absorção de idéias propostas pelos trabalhadores. $\mathrm{O}$ gerente da Fábrica X mostrou uma invenção originada de idéias deles: uma máquina para diminuir o esforço físico dos trabalhadores na movimentação dos motores de um local para outro. O problema foi resolvido com a criação de um braço mecânico que facilita tal tarefa. $\mathrm{O}$ gerente enfatiza:

\begin{abstract}
A filosofia da Fábrica é a do trabalho em equipe. Tudo sempre foi decidido em equipe. Assim, quando chegou o CCQ já existia um terreno fértil. Ora o que é o $C C Q$ ? São grupos, círculos de controle de qualidade, grupos de pessoas que visam a melhorias dentro da fábrica. Os grupos têm de se reunirem de tempos em tempos, sugerir uma idéia e implantá-la. Ora, já estamos acostumados a trabalhar em equipe. Agora, chegou a ginástica neste solo e a semente já está lá (Anexo 1).
\end{abstract}

\footnotetext{
${ }^{37} \mathrm{O}$ espaço físico da fábrica é arejado, limpo, amplo e repartido em várias seções, porém com um barulho ensurdecedor. Há grupos que estão na rebobinagem dos motores - colocam fios de cobre na parte interna do motor, atividade que exige bastante atenção, pois os fios tem de estar enrolados de forma precisa. A montagem do motor é realizada por partes, cada seção monta uma delas. Os motores são de tamanho grande e médio. Há dois fornos funcionando também, cujas redondezas ficam super quentes. Internamente, o barulho imenso advém por todos estarem trabalhando ao mesmo tempo, com a montagem dos motores ou com a testagem. Os testes feitos com os motores causam bastante barulho. O galpão é arrumado em divisões por seções, ou seja, não há divisórias, as máquinas e os grupos de trabalhadores é que dividem os espaços. Mas, tudo é arrumado, no lugar certo, não há sujeira espalhada. A Fábrica funciona em três turnos em cinco dias da semana: das 4h42s às 14h00, das. $14 \mathrm{~h} 00$ às $23 \mathrm{~h} 18$ e das $23 \mathrm{~h} 18$ às $4 \mathrm{~h} 42$. Não se trabalha mais no sábado, mas, se existir alguma necessidade de aumentar a produção, eles trabalham. Como a maioria é jovem, há uma disposição inerente às condições físicas da própria idade; no entanto, apesar de eles trabalharem em grupos, não existe espaço para conversas, principalmente por conta do barulho e da alta intensidade do trabalho que exige muita atenção no que se está realizando.

${ }^{38}$ Analisamos essa questão no segundo capítulo.

39 Sobre esse assunto tentamos junto ao gerente da Fábrica X, levantar informações sobre essa relação, de máquinas tecnológicamente desenvolvidas e o desemprego, mas ele não respondeu; em todos os momentos que tematizada sobre esse assunto, ele respondia com outras informações.
} 
Por outro lado, como a maioria dos trabalhadores completam a formação do ensino fundamental na própria escola da empresa, torna-se mais fácil implementar inovações e o trabalho em equipe nessa fábrica, pois eles habituam-se desde cedo com o modelo dessa organização, de acordo com declarações do gerente:

Essa filosofia da empresa penso que é extremamente válida, por quê? Porque, nós apostamos no colaborador quando ele tem 14 anos e aí ele entra na nossa escolinha. Lá na escolinha, eles também fazem ginástica. Aí eles ficam lá até os dezessete, dezoito anos. Eles saem para vir para a fábrica. Então nós estamos investindo e esse pessoal já começa a perceber essa cultura lá dentro da escola. Quem são os professores da escola? São funcionários da empresa, que de uma forma, ou, de outra, foram para a escolinha ensinar isso [a filosofia], isso vem sendo absorvido por eles (Anexo 1).

No espaço interno da Fábrica X existe um escritório fechado por paredes. Ele tem ar refrigerado e o barulho dos motores não atinge o local. O gerente geral da fábrica e outros auxiliares trabalham nesse escritório. Existe um chefe geral, subordinado ao gerente da fábrica, que circula entre as seções. Os demais chefes de seção trabalham no galpão da fábrica onde dispõem pequenas mesas em espaços mais próximos à produção. Em cada seção existe um quadro estatístico que mostra a produtividade da empresa, as metas atingidas, as metas a serem atingidas e o número de acidentes de trabalho por ano.

Na Fábrica X também são construídas caixas de madeira que são as embalagens dos motores destinados à exportação. Não há serviços terceirizados, todas as atividades necessárias à fabricação dos motores são feitas na própria empresa, da embalagem de madeira, para proteger os motores destinados à exportação, às tintas que pintam os motores e as carcaças. O ambiente de trabalho é mantido limpo e os próprios trabalhadores preocupamse em não sujá-lo, ao mesmo tempo em que vão trabalhando, vão limpando os arredores.

Na parte externa do galpão da fábrica vimos dois lagos, com gramados e flores ao redor; formando uma paisagem muito bonita. Ao redor da fábrica, os espaços também são amplos e tudo dá a impressão de grandiosidade.

A necessidade de produtividade é que define o tempo de produção. A concentração naquilo que está sendo realizado exige atenção, disposição total do trabalhador, condição sine qua non para o bom desempenho em cada seção. 
Para o trabalhador, tudo isso parece natural. Ao perguntar a um deles se não havia algo que podia ser reivindicado nessa empresa, ele disse: é que a [...], o pensamento da fábrica já é defender o lado humano, não só da máquina ... (Anexo 6). Para o entrevistado o lado humano da fábrica expressa-se: porque tem médico, tem dentista, almoço, aquela revisão periódica.

Isso tudo os trabalhadores compreendem como uma resposta da empresa aos bons trabalhos deles: Vamos supor, tu vais lutar pela fábrica como se tu fosses lutar pela tua casa, porque tu sabes que ela vai te tratar bem, ela vai dar o retorno, então tu também ajudas. Então, se tu vais tentar melhorar muito mais, tu acabas estragando, talvez até esse medo faça com que a pessoa conviva com isso (Anexo 6). Assim, para a maioria dos entrevistados, é um privilégio trabalhar nessa fábrica, devido aos benefícios que eles julgam ter como trabalhadores.

As atividades realizadas diariamente da mesma forma, portanto, repetidas milhares de vezes ininterruptamente durante a jornada de trabalho, somente sofrem uma parada para a realização da ginástica na empresa. Para uma grande maioria, tal parada significa lazer. Alguns compreendem o duplo aspecto que caracteriza pequenos intervalos durante o processo de trabalho: além de descansar os trabalhadores, torna-os mais produtivos por um período maior em tarefas intensas. No início do século passado, Taylor aplicou um método parecido às atividades cansativas, em uma certa fábrica, que dificultavam o aumento de produtividade.

Existe ainda garantia de emprego (algo próprio do modelo toyotista). O controle do tempo de trabalho está presente, mas não se confunde com as características do fordismo. A solicitação da participação do trabalhador com suas idéias, característica das novas gestões do trabalho, é de longa data. Trocam postos de trabalho entre eles, mas só nos cargos de gerenciamento (chefes de seções, gerentes de fábrica, diretorias) Há formação continuada, ou seja, a exigência de um perfil mais intelectualizado (na área técnica) para alguns, convém frisar. A limpeza nos galpões, a claridade no ambiente e tudo arrumado e no lugar certo, também é hábito antigo. Todos são tratados de forma bastante afetiva, pois fazem parte da família [...] (nome da empresa). O controle da produção é feito pelos chefes que expõem um quadro de previsão de produção com as estatísticas mensais e semanais, relacionando-o com o 
cumprimento das metas e não por luzes, como seria o modelo de organização do trabalho do Japão. O estoque é permanentemente atualizado, pois a demanda não pára. A criatividade dos trabalhadores também, segundo informações, sempre foram consideradas, antes do CCQ existia outra forma de reunião em equipe que chamavam de grupo de inventores.

A qualidade dos produtos, sua boa aceitação no mercado e a busca do baixo custo, tanto na produção quanto na venda e manutenção, coadunam-se com perfeição ao modelo de organização do trabalho dessa empresa, satisfazendo assim as aspirações planejadas. As idéias sobre os efeitos benéficos do trabalho para si mesmos e para a cidade estão de tal modo incorporadas pelos trabalhadores que eles, apesar de se darem conta de que todo o tempo de suas vidas foi transformado em tempo de trabalho, parecem conformados.

Será que nesta terra foi resolvido o confronto entre capital e trabalho, peculiar ao modo de produção capitalista?

Mas, mesmo diante desse equilíbrio social, já houve greve. Um trabalhador entrevistado, quando falou sobre o sucesso da empresa, avaliou que ela Teve as suas crises, teve até greve com o sindicato, mas mesmo assim foi crescendo, crescendo.

Perguntamos sobre a questão relativa à existência do sindicato dos trabalhadores e como foi essa greve, obtivemos a seguinte resposta:

Tem, mas não é radical como em São Paulo, a CUT, não é assim. Aqui se negocia. Aqui, como naquela época, a da greve, eu não sei se parou 100\%, eu, inclusive, trabalhei. Na minha visão, vejo que o sindicato não é radical, não é do tipo: não dá aumento então ninguém trabalha mais. Negocia-se, vai e volta, conversa um pouco, faz reunião (Anexo 6).

O entrevistado fez questão de realçar sua não participação na greve consolidando aquilo que considera uma forma 'educada' de fazer greve. À insistência em saber mais sobre a greve realizada e quando ela se deu, o trabalhador responde: foi na época de redução de jornada, da crise (Anexo 6) Segundo informações, a greve a que o trabalhador se referiu ocorreu em 1980, época em que os empresários queriam reduzir a jornada de trabalho e diminuir os salários; na ocasião em que a empresa estava com seus estoques encalhados. Aí houve greve? Aí houve greve. Nesses momentos as pessoas se juntam? Sim, se juntam! 


\section{GINÁSTICA NA EMPRESA: UMA TECNOLOGIA ORGANIZADORA DO TRABALHO}

Neste capítulo analisamos o programa Ginástica na Empresa como uma tecnologia organizadora do trabalho. Estamos considerando essa ginástica uma inovação tecnológica presente no processo interno de trabalho da Fábrica $\mathrm{X}$, acontecendo durante o expediente.

Covre (1990, p. 82) nos diz que "...a tecnologia não pode ser pensada só em termos de maquinaria, ela tem sua grande função, hoje, de organização e planejamento. De forma paralela, por exemplo, pensando a computação, não existe o soft sem o hard ".

Constatamos, no desenrolar da pesquisa, que a prática da Ginástica na Empresa pode constituir-se no que denomina Covre (1983, 1990, 1996): uma tecnologia organizadora do trabalho.

Como exercitação ${ }^{40}$ corporal orientada, não víamos a ginástica acontecer durante o expediente. Uma atividade até então realizada somente em academias, clubes, em instituições militares e em escolas, hoje, ao fazer parte do processo de trabalho e acontecendo na jornada de trabalho, causa, no mínimo, curiosidade. Nesta pesquisa, ela tornou-se uma das dimensões instigantes e está significando, nessa realidade, uma nova tecnologia.

Apresentamos, ainda, na exposição desse capítulo, no primeiro item, um perfil do grupo de trabalhadores pesquisados, bem como detalhes relacionados ao tipo de atividade produtiva que acontece no processo de fabricação de motores elétricos. No segundo item, a Ginástica na Empresa, como um produto do Serviço Social da Indústria (SESI), refletimos a sua origem comercial. Analisamos a proposta do programa Ginástica na Empresa considerando o corpo biológico como o pressuposto de sua relação com o trabalho no terceiro item. Como quarto item chegamos na Ginástica na Empresa como uma tecnologia organizadora do trabalho. O quinto item evidencia o corpo (com dores, cansaço e estresse) nessa tecnologia, o qual tem como subitem a tecnologia desse corpo que produz e também

\footnotetext{
${ }^{40}$ Estamos denominando ginástica como uma exercitação corporal orientada, ou seja, que se faz a partir de uma elaboração anterior, exigindo-se para tanto uma sistematização teórica.
} 
brinca. Por fim, no último item, analisamos o corpo que brinca no tempo de trabalho como uma possibilidade de atividade lúdica, porém não de lazer, problematizando a distinção entre trabalho e lazer.

\subsection{O GRUPO DE TRABALHADORES E O TIPO DE ATIVIDADE DESENVOLVIDA NA FÁBRICA X}

Antes de adentrarmos propriamente nas peculiaridades da ginástica no processo interno de trabalho, caracterizaremos alguns traços do grupo de trabalhadores da Fábrica X, bem como o tipo de atividade laboral aí realizada.

Para chegarmos a essa fábrica primeiro escolhemos a empresa. Essa escolha se deu a partir de dois critérios definidos a priori: o primeiro foi que a empresa dispusesse de tecnologias avançadas em seu processo produtivo e o segundo foi que ela adotasse o programa Ginástica na Empresa.

Segundo informações do coordenador estadual de ginástica do SESI do Estado de Santa Catarina (Anexo 2) essa empresa foi a primeira da região norte do Estado a acolher esse programa em expediente interno de trabalho e, segundo informações variadas ${ }^{41}$, ela possui destaque pelo seu desempenho tecnológico, tanto produzindo tecnologia, quanto implementando-a em sua base de produção.

Devido a semelhanças entre as fábricas do parque fabril I, II, III e IV dessa empresa, privilegiamos uma delas, que faz parte do parque I e II, denominando-a Fábrica X, da qual procuramos conhecer mais de perto o processo interno de trabalho com a implementação do programa de ginástica, supondo que, como ela detinha maior tempo de experiência com esse programa, poderíamos estar diante de um campo empírico mais rico de informações.

\footnotetext{
41 Obtidas em várias fontes: Núcleo de Pesquisas sobre a Industrialização do Estado de Santa Catarina CSE/UFSC, DIEESE, FIESC, SESI e Escola Sul da CUT. Elas foram unânimes em indicar esta empresa como uma das que mais implementa e desenvolve tecnologias em sua base técnica de produção, bem como em seus produtos.
} 
Os trabalhadores da Fábrica X, de um modo geral, são jovens que almejam, pelo menos, as condições materiais de existência oferecidas por um emprego seguro e promissor. Conforme o quadro abaixo, dos 118 respondentes do questionário, a maioria não ultrapassa 35 anos de idade. Observamos que os jovens estão em postos de trabalho que exigem força física no manuseio de motores e que os poucos com mais idade, estão na manutenção de fornos.

TABELA 13 - Distribuição de faixa etária

\begin{tabular}{c|c}
\hline Faixa etária & Porcentagem \\
\hline Até 25 anos & 32,07 \\
\hline De 26 a 30 anos & 18,24 \\
\hline De 31 a 35 anos & 18,24 \\
\hline De 36 a 40 anos & 13,07 \\
\hline De 41 a 45 anos & 5,31 \\
\hline De 46 a 50 anos & 2,59 \\
\hline Não responderam & 10,48 \\
\hline Total & 100,00 \\
\hline
\end{tabular}

Segundo o gerente, nessa empresa ainda existe incentivo e garantia de emprego duradouro e não há interesse na rotatividade de seus empregados. Inclusive, a própria identificação do trabalhador (exibe um tipo de crachá) indica seu tempo de trabalho na empresa. Esse mesmo gerente já completou vinte anos, segundo suas palavras: de dedicação à empresa (Anexo 1).

A maioria dos trabalhadores do grupo selecionado é do sexo masculino. Conforme levantamento realizado, dos 118 respondentes do questionário, 81,1 \% são homens e 18,9\% mulheres. A pequena quantidade de pessoas que formam a família desses trabalhadores indica uma tendência contemporânea de um número reduzido de pessoas na família. As famílias de quatro pessoas perfazem 50,9\% do total dos respondentes; de até dois trabalhadores, o percentual é $18,63 \%$; até cinco pessoas $14,4 \%$; até sete pessoas $6,76 \%$ e não responderam $9,31 \%$ de pessoas.

Segundo dados da prefeitura da cidade, de 1991 a 1996 houve um decréscimo na média de pessoas que compõem os domicílios, como mostra a tabela abaixo. Observamos também que, de 1970 a 1996, a movimentação e o aumento do número de pessoas na zona urbana são bem mais significativos: subiu 5,57 vezes, ou seja, passou de 14.752 para 72.118 , enquanto que na zona rural passou de 15.494 para 20.964, subindo apenas 1,35 vezes. Outro detalhe é que, em 1970, a população rural de Jaraguá do Sul era maior do que a urbana, de 
forma que isso expressa a característica agrícola de seu movimento econômico, dando a entender que a zona rural praticamente se paralisou, enquanto a urbana, acompanhando a industrialização da cidade, ampliou-se consideravelmente. Conjugada a essa condição, observamos que, em 1996, a quantidade de homens sobrepunha-se à de mulheres. Encontramos a mesma situação no chão da fábrica, como expomos à frente. Esse dado parece nos indicar que o mundo do trabalho industrial, até essa época, que é recente, está caracterizado majoritariamente pela presença do homem ${ }^{42}$. No entanto, nessa mesma empresa, já percebemos uma tendência de mulheres ocuparem postos de trabalho antes só assumidos por homens (análise baseada em uma conversa com o gerente da Fábrica X).

TABELA 14 - População segundo o sexo, zona urbana e zona rural (1940/1996)

\begin{tabular}{c|c|c|c|c|c|c|c}
\hline Ano & $\mathbf{1 9 4 0}$ & $\mathbf{1 9 5 0}$ & $\mathbf{1 9 6 0}$ & $\mathbf{1 9 7 0}$ & $\mathbf{1 9 8 0}$ & $\mathbf{1 9 9 1}$ & $\mathbf{1 9 9 6}$ \\
\hline Total & 23.495 & 27.240 & 23.197 & 30.246 & 48.534 & 76.968 & 93.082 \\
\hline Homens & 12.103 & 14.024 & 11.877 & - & 24.487 & 38.911 & 47.143 \\
\hline Mulheres & 11.392 & 13.216 & 11.320 & - & 24.047 & 39.057 & 45.939 \\
\hline z. Urbana & 4.110 & 4.812 & 4.835 & 14.752 & 32.281 & 62.565 & 72.118 \\
\hline z. Rural & 19.385 & 22.428 & 18.812 & 15.494 & 16.253 & 14.403 & 20.964 \\
\hline $\begin{array}{c}\text { Média pessoa por } \\
\text { domicílio }\end{array}$ & - & - & - & - & - & 4,08 & 3,79 \\
\hline
\end{tabular}

FONTE: IBGE

ELABORAÇÃO: Agência do IBGE de Jaraguá do Sul

A cidade de Jaraguá do Sul faz parte de estatísticas promissoras em relação a outras cidades. Seus dados indicam que a população possui bens duráveis, como também bens de consumo. A maioria dos que trabalham na Fábrica X, 83,3\%, possui casa própria, cerca de $12 \%$ deles residem em casas alugadas e $0,5 \%$ moram de outra forma.

No item dos eletrodomésticos, a maioria dos respondentes afirma possuir de máquina de lavar roupa, que seria um item mais caro, a vídeo- cassete. Já para a locomoção até a fábrica, os meios de transporte variam. Do total respondido, 6,78\% dos trabalhadores usam a bicicleta ou o ônibus para se transportar ao trabalho; de bicicleta vão 20,35\%; a maior parte $(50,76 \%)$, utiliza como meio de transporte o ônibus da empresa; a pé vão $5,93 \%$; de automóvel próprio vão 13,56\%; de carona, 0,84\%; de moto, $0,84 \%$; e de outra forma, $0,84 \%$.

\footnotetext{
${ }^{42}$ Observamos no chão da fábrica mulheres jovens dividindo postos de trabalho com homens. Até há bem pouco tempo a atividade observada seria considerada masculina, pois exige movimentação de motores pesados. Talvez, estejamos vislumbrando uma possível mudança dos parâmetros de definição dos papéis profissionais para homens e mulheres, separadamente.
} 
Quanto ao estado civil, apesar de os entrevistados serem bem jovens, $72 \%$ se declararam casados além de que alguns disseram estar se preparando para casar. Apenas $27 \%$ são solteiros e somente $0,5 \%$ são separados. É sabido que na cidade de Jaraguá do Sul a estatística de divórcios é significativa, porém, não é o caso dos trabalhadores da Fábrica X.

A formação educacional desses trabalhadores é incentivada, e até certo ponto exigida. A empresa possui um centro de treinamento com uma escolinha ${ }^{43}$ técnica. Cabe aqui ressaltar um fato ocorrido na primeira crise vivida pela empresa na década de oitenta do século passado. Segundo Ternes (1997) uma vez tendo de parar a produção devido aos estoques crescentes, em vez de dispensar os trabalhadores, ou de deixa-los parados dentro da fábrica, foram oferecidos cursos de atualização ${ }^{44}$ para solucionar o problema do tempo vago.

Essas medidas favoreceram a consolidação da boa imagem e de exemplo divulgado pela empresa junto à opinião pública de Jaraguá do Sul, de considerar e respeitar o ser humano. É com orgulho que muitos se referem a esta empresa.

Em Jaraguá do Sul, segundo depoimentos acolhidos aleatoriamente na população local, não existe problema social causado pelo desemprego. É unânime a afirmação de que trabalhador especializado, nessa cidade, não fica desempregado e a concepção de que escolarização é sinônimo de garantia de emprego também está presente na visão dos trabalhadores. Porém, de acordo com a tabela abaixo, existe índice de desemprego na cidade de Jaraguá do Sul não muito diferente do índice do Estado de Santa Catarina.

TABELA 15 - Taxa de desemprego (\%)

\begin{tabular}{c|c|c}
\hline Brasil & Santa Catarina & Jaraguá do Sul \\
\hline 7,1 & 4,3 & 4,0 \\
\hline
\end{tabular}

FONTE: PMJS

\footnotetext{
${ }^{43}$ Segundo Ternes (1997) em 1968 surge a escola de formação de mão-de-obra. É desenvolvida como um Centro de Treinamento e desde a sua fundação preocupa-se com a preparação de jovens, direcionando-os à parte técnica de que a empresa necessita. Nessa época, não existia, em Jaraguá do Sul, reservas de mão-de-obra qualificada para atuar na área de motores elétricos. Hoje, existe também a Escola Técnica Federal; porém, a vantagem de estudar na escola da empresa é que ela garante emprego ao se concluir o curso, além de os alunos receberem uma bolsa de estudo durante o tempo dessa formação.

${ }^{44}$ As temáticas tratadas foram sobre meio ambiente, saúde, informações técnicas. Os trabalhadores tinham duas horas por dia de cursos denominados de atualização. Por que não realizaram atividades ditas de Lazer? Ninguém soube responder essa pergunta.
} 
Segundo Ternes (1997), a empresa sentiu o problema da formação profissional logo ao iniciar a ampliação da sua primeira fábrica de motores elétricos e, com isso, criou uma política de formação profissional ativa até os dias atuais. Essa falta de força de trabalho especializada, percebida já por volta de 1964, ocorreu no início do processo de expansão continuada dessa empresa, e como a cidade era economicamente organizada a partir da produção agrícola, as exigências de força de trabalho para a fabricação de motores não coincidiam com a oferta disponível. Daí em diante, seus diretores resolveram a questão com a promoção de cursos, palestras, e com a fundação da já citada escola técnica (Centro Profissional).

Dos que responderam ao questionário, $28,5 \%$ tinham o primeiro grau completo; $47,4 \%$, o segundo grau completo; $13 \%$, o segundo grau incompleto; $0,9 \%$, ensino superior; $1,7 \%$, ensino superior incompleto; e $8,5 \%$ não responderam. Se considerarmos que a maioria possui o primeiro grau completo e que metade deles tem o segundo grau completo, podemos afirmar que existe valorização de escolaridade nessa empresa, pois no chão da fábrica estão até universitários. A empresa tem em sua escolinha ${ }^{45}$ os alunos da rede pública local de ensino que obtêm os melhores desempenhos, sendo que o critério é o da maior nota obtida.

$\mathrm{O}$ gerente da Fábrica $\mathrm{X}$, ao ser questionado sobre qual vantagem, fora $\mathrm{O}$ atendimento à mão de obra específica originada na escola da empresa, responde explicitando a relação de formação e investimento para o futuro, conforme palavras dele já citado na página 66 do capítulo anterior.

A Fábrica X faz o processamento da usinagem, bobinagem (fiação, funilaria), montagem e testes dos motores. Essas atividades exigem dos trabalhadores uma boa preparação física porque, para executá-las, é necessário força e coordenação motora para manusear os motores. Os motores ${ }^{46}$ são de médio e grande porte e relativamente pesados. São

\footnotetext{
${ }^{45} \mathrm{Em}$ conversas fora da fábrica, soubemos que existe uma seleção dos melhores alunos da rede pública. Os melhores da quinta série são convidados a estudar nessa escolinha recebendo um terço do salário mínimo.

${ }^{46}$ Os motores elétricos fabricados são motores industriais de alta e baixa tensão. Os de baixa tensão são os trifásicos com potência de 0,16 a $500 \mathrm{cv}$; os de alto rendimento plus com potência de 1 a $500 \mathrm{cv}$; motores à prova de explosão com potência de 0,5 a $500 \mathrm{cv}$; motores para área de risco com potência de 0,5 a $500 \mathrm{cv}$; motores inverter duty com potência de 0,5 a $500 \mathrm{cv}$; motores para bomba monobloco com potência de 1,5 a $100 \mathrm{cv}$; motofreios trifásicos com potência de 0,16 a $30 \mathrm{cv}$; motoserra trifásico com potência de 3 a $10 \mathrm{cv}$; motores monofásicos blindados com potência de $1 / 4$ a $12,5 \mathrm{cv}$; motores carcaça de alumínio trifásicos com potência de 1 a $3 \mathrm{cv}$ e motores de corrente contínua com potência de 0,5 a $3000 \mathrm{cv}$. Já os de alta tensão são os motores trifásicos de indução (linha master) com potência de 100 a $22.000 \mathrm{kw}$, tensões até $13,8 \mathrm{kv}$ e os motores trifásicos de indução (linha $\mathrm{H}$ ), fechados ou abertos com potência de 100 a $2.500 \mathrm{kv}$, tensões até $6,6 \mathrm{kv}$; e os motores
} 
motores elétricos para uso industrial tradicionais ${ }^{47}$ monofásicos e trifásicos, que servem para gerar eletricidade e transformar energia elétrica em mecânica. Os principais motores produzidos na Fábrica $\mathrm{X}^{48}$ são os trifásicos de 50 a 500 cavalos de potência.

A área construída da fábrica abrange 5.825 metros quadrados. A capacidade produtiva é de 150 motores diários. O horário de funcionamento do chão da fábrica é vinte e quatro horas ininterruptos, dividido em três turnos: o primeiro vai das quatro horas e quarenta e dois minutos às quatorze horas; o segundo vai das quatorze até as vinte e três horas e dezoito minutos, e o terceiro turno vai das vinte e três e dezoito minutos até as quatro horas e quarenta e dois minutos. $\mathrm{O}$ funcionamento da administração é das sete horas e trinta minutos até as dezessete horas e dezoito minutos.

As tarefas predominantes na montagem dos motores elétricos da fábrica são correlacionadas comumente ao trabalho manual, porém com exigências mais complexas. Segundo informações do gerente da Fábrica $X$, eles são treinados e formados tanto na escolinha $^{49}$ da empresa quanto em cursos de reciclagem, como também na Escola Técnica Federal da cidade.

A resposta do gerente da Fábrica $X$ à pergunta sobre a formação dos trabalhadores, se era restrita à escola da empresa, foi:

Não[...]. Em 1971, quando iniciou a escolinha era praticamente toda a formação de lá. Hoje, não, nós já temos várias escolas, várias fontes de abastecimento de mão- de-obra, mas antigamente quando Jaraguá estava crescendo e não era tão aberta, a formação era só da escola. Hoje vem gente de vários lugares. Vem do RS, vem do PR, vem de SP. Estão confluindo para cá procurando possibilidades e condições melhores de vida. Quando chegam aqui encontram um celeiro forte.Por quêe? Porque a empresa dá oportunidade de criar, de participar do seu

fracionários, são os NEMA monofásicos e trifásicos de $1 / 8$ a 3cv, que servem para aplicações diversas tais como: bombas, condicionadores de ar, lavadoras de roupa, mínimotores para movimentação de ar, ceifadores de grama, motofricção, portões eletrônicos, espremedores de frutas, equipamentos odontológicos e hospitalares, esteiras ergométricas.

${ }^{47}$ Além desses motores tradicionais há inovações na produção com motores para condicionador de ar e para portão eletrônico, além de ela ser ampliada com motores de carcaça de alumínio e com os de alto rendimento Plus.

${ }^{48}$ Principais equipamentos da Fábrica X: Uma linha de bobinagem manual; uma isoladora de estatores; duas bobinadeiras e inserção mecanizada; duas máquinas de amarrar mecanizada; uma linha de gotejamento de resina; uma fresadora wota; dois tornos de usinagem de encaixa; uma linha de montagem; duas cabines de pintura normal; um jato com cabine para pintura especial; um laboratório de ensaios elétricos.

${ }^{49}$ na área dos motores elétricos. Hoje, já existe a Escola Técnica Federal, porém, a vantagem de estudar na escola dessa empresa é que ela garante o emprego ao concluir-se o curso além de os alunos receberem uma bolsa de estudo durante o tempo de formação. 
crescimento, e isso tudo aliado a essas novas tendências. Então, tu vais indo, e vais se emocionando, e vais continuando e ficando (Anexo 1).

Convém ressaltar a exigência específica, nesse tipo de trabalho, de precisão nos movimentos que devem ser realizados em curto espaço de tempo, pois existe um número mínimo de peças a serem produzidas num tempo determinado, sem erros. Isso implica alta repetitividade desses movimentos imposta, principalmente, pela exigência de produtividade com qualidade. Dessa forma, a atividade motora é a mais requerida na montagem desses motores, recaindo nas mãos, braços, ombros, na postura a força física; além do que os trabalhadores desenvolvem esse trabalho, praticamente, o tempo todo, em pé.

\subsection{A GINÁSTICA NA EMPRESA: UM PRODUTO DO SESI E A SUA RELAÇão COM O TRABALHO}

No Brasil, o SESI de Minas Gerais ${ }^{50}$ foi construtor e responsável pelo modelo nacional do programa, constituindo-se num programa de ginástica de referência para a ISO $9000^{51}$. Ele montou um software com exercícios ${ }^{52}$ corporais chamados de compensatórios, vinculando-os ao corpo que produz.

A atividade que os trabalhadores realizam na fábrica com os motores elétricos exige um enorme esforço físico. Eles trabalham em células (pequenos grupos) ou em linhas de montagem (individualizados), em pé e não há como mudar de posição nem de parar o que se está fazendo. Uma quantidade certa de motores deve ser montada a cada dia, há uma meta de produção a ser atingida e a demanda é ininterrupta. Esse número tende a crescer sempre, portanto, a produtividade é deveras exigida.

\footnotetext{
${ }^{50}$ Informação repassada pelo coordenador de ginástica do SESI/SC (Anexo 2).

51 ISO 9000: se refere "à Organização Internacional para a Normatização (International Organization for Standardization), entidade que reúne organismos normalizadores de 91 países e edita normas internacionais" (Dieese, 1994, p. 103).

${ }^{52}$ O SESI selecionou uma média de 100 exercícios que possam, em combinação com os fatores de risco (que são levantados no diagnóstico das condições de trabalho), melhorar as possíveis alterações corporais ocorridas por causa do movimento executado no referido trabalho.
} 
A Ginástica na Empresa, como produto do SESI, vem sendo implementada há quase dez anos no Brasil ${ }^{53}$. Em Santa Catarina ela sofreu algumas modificações. Uma delas é no que se refere à não obrigatoriedade na participação dos trabalhadores e a outra é a de ter sido acrescentado o objetivo de atingir a vida do trabalhador fora do trabalho. O SESI procura estimular a atividade física como forma de manutenção de saúde, com o chamado lazer ativo $^{54}$.

Para a composição dos exercícios adequados, os proponentes do programa necessitam de um diagnóstico dos movimentos que os trabalhadores realizam diariamente. Feito isso, eles selecionam os exercícios corporais que possam promover a movimentação das partes do corpo que não são solicitadas naquele tipo de trabalho. Essa é a orientação da ginástica compensatória. Existe, ainda, a ginástica preparatória, cujos exercícios visam a ativar o corpo todo para o início das atividades do trabalho.

Relembramos que as atividades de trabalho observadas nesse estudo são as de montagem de motores elétricos de médio e de grande porte.

Ainda existe outra alteração em relação ao programa elaborado em Minas Gerais $^{55}$, que é a inclusão de outros recursos que, na prática da ginástica nesta empresa, permitem o trato de questões de ordem subjetiva no desenrolar do programa, tais como: buscar maior socialização entre os trabalhadores, maior integração, fomentar amizades, afetos, alegria, perceber o outro, enfim, ter em vista - como conseqüência já observada pelo gerente da Fábrica $\mathrm{X}$ - um entrosamento maior de equipe, tudo resultando num melhor clima organizacional do trabalho. Chamamos atenção para os resultados dessa tecnologia.

\footnotetext{
53 Não obtivemos a informação de como e por que e ela começou a existir aqui no Brasil, nem com os trabalhadores do SESI de Minas Gerais e nem com os trabalhadores da coordenação estadual do SESI/SC. A dúvida permanece e entendemos que isso pode indicar que a referida proposta foi se construindo sem planejamento, por modismo ou imitação. Segundo Costa (1990), a relação da empresa com a educação física foi estabelecida na era Vargas, oficializada pelo Decreto-lei no 3.199 de 14 de abril de 1941, sendo este o primeiro momento. O segundo momento, continua o autor, acontece logo após a Segunda Grande Guerra com a criação do Serviço Social da Indústria (SESI) e do Serviço Social do Comércio (SESC), Decreto-lei 9.853 de 1946 com a contribuição compulsória dos trabalhadores, no valor de $1,5 \%$ sobre a folha de pagamento de cada empresa. Essas instituições denominadas sócio-culturais e esportivo-recreativas centralizaram por muito tempo, ainda com influências hoje em dia, as promoções de lazer para os trabalhadores. O terceiro momento, segundo o autor, é o que inicia entre as décadas de 1970 e 1980, porém se efetivando a partir da década de 1980, sendo que, nesse período, houve um reordenamento e as empresas preocupadas com as relações internas de trabalho, centraram mais as suas ações de esporte e lazer por dentro delas.

${ }^{54}$ Informação obtida com o coordenador estadual do programa do SESI/SC. Encontra-se outras informações nos endereços: http://www.cds.ufsc.br/nupaf.html e http://www.fiescnet.com.br/SESI.

${ }^{55}$ Informação obtida junto ao coordenador estadual do programa no SESI/SC (Anexo 2).
} 
A participação deve ser espontânea, porém no momento da implantação do programa há intervenções planejadas com palestras de sensibilização ${ }^{56}$, cujo conteúdo apresenta os benefícios que a ginástica pode promover aos seus praticantes, contrapostos aos malefícios que atingem quem não pratica exercícios físicos. A adesão de todos os trabalhadores de cada fábrica ao programa é uma preocupação constante dos seus coordenadores.

Para planejar a ginástica, os responsáveis pelo programa - coordenadores do SESI - realizam o diagnóstico já referido, antes da sua implantação. Perguntamos ao coordenador estadual de Santa Catarina como o SESI consegue realizar esse diagnóstico para planejar as atividades, e ele expôs a dificuldade para conseguir os dados, como também para avaliar outras consequiências do programa:

[...] não temos dados precisos em relação a isso, porque a gente ainda tem uma dificuldade de medir. Muitas vezes a empresa não nos fornece dados que a gente possa medir. A gente ainda está num processo de comprometimento com a empresa ganhando algum espaço para que ela comece a estar sensível para ajudar nessa forma de medir, mas não é fácil. Outra forma de detectarmos os dados é percebermos a diminuição de procuras ao ambulatório [...]. Algumas empresas, que têm bem organizado o serviço ambulatorial, conseguem medir a quantidade de pessoas que vão ao ambulatório[...]. Mas, outra forma de medir é a própria questão das faltas, a diminuição das faltas, o absenteísmo (Anexo 2).

A relação entre o SESI e a empresa é comercial, isto é, o SESI elaborou um produto e o está vendendo nacionalmente. Um serviço que é vendido ${ }^{57}$ por ele. Ele denomina produto $^{58}$ que precisa ser comercializado e que, para se manter no mercado, precisa ser bem aceito; por isso o empenho no acompanhamento do programa quando ele é comprado por uma empresa.

Geralmente, na relação Trabalho ${ }^{59}$ e Ginástica na Empresa, ela, a ginástica, é apresentada como uma solução para os problema de LER (Lesões por Esforços Repetitivos) e DORT (Distúrbios Ósteo-musculares Relacionados ao Trabalho).

\footnotetext{
${ }^{56}$ Palavras do coordenador estadual do programa no SESI/SC (Anexo 2).

57 De acordo com as informações conseguidas, o SESI vende o produto (a Ginástica na Empresa), porém o pagamento não é repassado para os Professores do programa. Eles são assalariados do SESI. Vale dizer que quem lucra com o produto é o próprio SESI.

${ }^{58}$ Palavras do coordenador estadual do SESI/SC.

${ }^{59}$ É interessante observar que na literatura sobre a Reestruturação Produtiva (Carvalho e Bernardes, 1996; Codo e Almeida, 1995; Coriat, 1994; Dieese, 1996; Fidalgo, 1996 e Lacerda, 1998) que aborda as novas formas de
} 
Esses problemas causados pelo trabalho repetitivo e intenso encontram lugar de destaque, para as suas explicações e soluções, nos fundamentos de uma abordagem biológica (corpo biológico) de análise, particularmente em seu componente fisiológico e com algumas explicações mecânicas.

Na década de 70, o Japão foi o primeiro que reconheceu a LER como um problema de afecções músculo-esqueléticas oriundo do trabalho. Assim, a incidência crescente desses problemas era uma combinação de vários fatores relacionados ao trabalho, como do tipo de posto a fatores organizacionais do trabalho, uso de certas máquinas (computador), trabalho repetitivo, produtividade exigida e também as dimensões afetivas, que se tornam presentes quando aumenta o grau de responsabilidade e comprometimento com a produção impostas pelos chefes ou pelos próprios colegas (Codo, 1995).

Dessa forma, a justificativa para a implementação dessa tecnologia na empresa é a de que ela pode evitar o aumento de LER ou DORT. A afirmação do gerente da Fábrica X corrobora essa justificativa:

[...] hoje, na minha fábrica, eu tenho muito esforço físico e para continuar trabalhando tenho que aumentar minha produtividade. Eu não vou, para aumentar minha produtividade, colocar mais gente fazendo esforço para me dar mais problemas. Não é por aí. Eu tenho que fazer o quê? Eu tenho que provocar o relaxamento desse pessoal, eu tenho que ajudar esse pessoal na postura para fazer esse trabalho. Agora, aquilo que sabidamente o homem não consegue fazer, não se adapta para fazer por causa do esforço, eu tenho que colocar equipamento que o permita. Hoje eu tenho equipamentos que superam sobremaneira o esforço do homem, porém, tem tarefas em que não posso abrir mão do homem. A minha parte é muito peculiar nesse trabalho, tem alguns motores que só tem condição de se fazer manualmente (Anexo 1).

Segundo ele, houve $70 \%$ de diminuição de baixas ambulatoriais depois que a ginástica foi adotada no expediente do trabalho; uma estatística realmente significativa.

O gerente também vislumbra elementos a mais que permeiam essa prática:

Já existia uma idéia. Na [... $]^{60}$ acionamento, que é uma das empresas do grupo, já tinha esse tipo de trabalho. Na [...]motores, que é a maior empresa do grupo, a Fábrica $\boldsymbol{X}$ foi a primeira. Tínhamos alguns casos de LER, então, optou-se por colocar esse programa como uma maneira de reduzir, de uma ou outra pessoa, a

organização e gestão de trabalho, não se comenta sobre a inclusão da Ginástica na Empresa. No máximo citam esse elemento demonstrando que esse assunto ainda está pouco analisado.

${ }^{60}$ Optamos não mencionar o nome da empresa e por isso estamos usando a simbologia [...] para substituí-lo. 
"potencialidade" de se ter LER. Com a minha chegada aqui houve essa abertura e tivemos como essa conclusão acontecer. Estimulo todos a participarem desse programa porque eu acho positivo; inclusive eu pratico, embora essa prática não tenha provocado nenhuma alteração porque eu pratico exercício fora da empresa. Mas ele predispõe a pessoa para a jornada de trabalho, como acontece aqui. No horário das $15 \mathrm{~h}$ acontece um torpor, ao fazer o exercício melhora; na própria postura você começa a fazer um ou outro alongamento que melhora. Ora você passa por aí e vê uma ou outra pessoa se alongando. Você começa a ver esse tipo de atitude, coisa que antes não acontecia. Não está acontecendo nenhum constrangimento. O pessoal da produção que passa muito tempo em pé, de vez em quando está se alongando. Além disso, criou-se uma outra coisa que é doze minutos de integração; essas brincadeiras em que um faz força contra o outro, as caminhadas em volta do lago. Inclusive vamos trabalhar uma outra idéia em decorrência disso aqui. Essas caminhadas causam um relaxamento e uma integração muito boa e isso causa uma melhora na produção. São subprodutos que estão saindo desse trabalho que já está iniciado (Anexo 1) Grifos nossos.

Interpretamos subproduto como outras conseqüências, antes não pensadas.

Essa ginástica funciona como uma tecnologia que aumenta a eficiência dos trabalhadores; além disso, faz parte dos critérios de certificação de qualidade da ISO 9000. As empresas que adotam esse programa ganham pontos para conseguir essa certificação de qualidade, que serve para promoção dos seus produtos no mercado.

As características que encontramos na prática dessa ginástica e que a diferenciam de outras ginásticas conhecidas ${ }^{61}$ são a não obrigatoriedade ${ }^{62}$ e o fato de que, além de apontar para o corpo produtivo, considera um corpo que brinca. É realizada em pequenos grupos chamados de células, com o máximo de 16 pessoas. Um dos operários, que é chamado de facilitador, assume voluntariamente o papel de orientador. Para assumir esse papel, ele coloca seu nome à disposição da coordenação do programa (composta de professores de educação física do SESI), com a qual ele participa de uma reunião mensal. Esses facilitadores são trocados de seis em seis meses.

As sessões (aulas) acontecem no próprio local do trabalho ou fora da fábrica em que trabalham. Na Fábrica X, uma vez por semana a prática da ginástica é substituída por uma caminhada em volta do lago que há na área ao redor da fábrica. O mesmo uniforme usado

\footnotetext{
${ }^{61}$ Em Marinho, I. P. (sem data, p 10-23) encontramos explanação sobre variados tipos de ginásticas, bem como sua classificação.

${ }^{62}$ Não é obrigatória, mas há uma cobrança, disfarçada, de participação de todos. Numa reunião da coordenação do SESI com os facilitadores da Fábrica X vimos que essa preocupação era presente, ou seja, não é totalmente espontâneo, existem formas indiretas de convencimento.
} 
para trabalhar é, também, vestimenta para as sessões ou caminhadas, que duram de 8 a 12 minutos, duas vezes por turno, diariamente.

Essas sessões constituem-se de exercícios $^{63}$ de alongamento, movimentos articulares, brincadeiras e movimentações com exercícios de toque entre os participantes. Elas vêm prontas no software do SESI, porém, na Fábrica X, eles alteram alguns detalhes. A planilha é trocada por outra, mensalmente. Cada turno tem os seus horários fixos para a ginástica. Em alguns ela acontece antes do trabalho; é a chamada ginástica preparatória. No horário estipulado para a aula, os facilitadores apitam, e cada grupo segue, disciplinadamente, para o local já definido para a sessão.

Nas observações, vimos que há uma grande adesão à prática da ginástica; poucos trabalhadores não participam. Outra observação é que a maioria deles participa efusivamente das sessões. No entanto vimos, alguns trabalhadores entre os que participavam da ginástica fora do galpão da fábrica, fumando.

Segundo a primeira ${ }^{64}$ coordenadora do programa do SESI local e o coordenador estadual do programa, não há problema em esses facilitadores não serem professores de educação física $^{65}$, pois eles não estão procurando um movimento perfeito, nem existe um padrão de execução idealizado ... é só passar os exercícios, os alongamentos e as brincadeiras sem exigir nada, só participação (Anexo 3).

\subsection{A GINÁSTICA NA EMPRESA E O PRESSUPOSTO DO CORPO BIOLÓGICO}

As características biológicas humanas são universais, apesar de existirem diferenças orgânicas entre os seres humanos. Silva (2001) denomina máquina química as dimensões do corpo que são tratadas de forma universal e que o caracterizam como parte da

\footnotetext{
${ }^{63}$ Uma aula compõe-se de exercitação corporal orientada para o alongamento muscular e de brincadeiras variadas, com oportunidades de toque entre os trabalhadores.

${ }^{64}$ No início da coleta de dados dessa pesquisa, havia uma coordenadora do SESI local, no segundo ano ela foi substituída por outra.

${ }^{65}$ Preferimos não nos posicionar diante dessa questão, haja vista ter problemas suficientes para ser digna de uma pesquisa, ou seja, qualquer análise seria superficial e apressada.
} 
natureza. Uma combustão química ${ }^{66}$, quando ocorre nos músculos, para a produção de energia necessária para a realização de uma ação, obedece a um mesmo padrão para todos os seres humanos; essa uniformidade dos componentes fisiológicos está sendo denominada aqui de componente material - aquele que se pode medir e quantificar - e é o fundamento teórico da Ginástica na Empresa. Observamos, também, nessa prática, outros componentes, aqui denominados de subjetivos que não permitem medi-la ou quantificá-la com exatidão, que também compõem e sustentam a prática dessa ginástica, porém, ainda sem sistematização teórica suficiente para dar conta da unidade entre os componentes materiais e subjetivos.

Observamos, ainda, que entre os fundamentos teóricos dessa proposta de ginástica, não há sistematização que contemple o corpo que brinca, ou seja, que faça a relação explícita do elemento lúdico presente com as brincadeiras e incorporado às aulas nos corpos concretos, e únicos de cada pessoa que delas participam. Pois, aquele corpo que brinca é o mesmo que produz e, naquele momento, está sendo evidenciado sob outro ponto de vista que não é o da produção, da performance física, do rendimento e da produtividade, mas o de uma conotação do sensível, do expressivo, de tal sorte que extrapola, momentaneamente, o âmbito das relações de trabalho. Nesse sentido, passa a constituir relações de prazer, relaxamento e descontração, e com isso vai proporcionando, ao mesmo tempo, uma maior socialização entre os trabalhadores participantes dessa prática.

Nas palavras de um entrevistado: [...] nos aproximamos mais um do outro; já para outro, a avaliação foi: brincamos e fica mais divertido o dia-a-dia do nosso trabalho; um terceiro diz: ótimo, na roda da ginástica se conhece melhor o outro (Anexo 6).

Contudo, a proposta que vem num programa de computador do SESI de Minas Gerais segue um padrão de exercícios fundamentados na disciplina do corpo e nos conhecimentos do corpo fisiológico (corpo biológico) e mecânico. Nas palavras do coordenador estadual do SESI, os fatores que definem e fundamentam essa prática se encontram no

[...] software que nos permite, dependendo do diagnóstico que se faz, propor uma: receptividade, compressão mecânica, força submáxima, posturas inadequadas na região escapular, na região lombar, postura sentada, o próprio gênero e outros. Então, ele levanta alguns fatores que são considerados fatores de risco e, a partir

\footnotetext{
${ }^{66}$ Esses aspectos serão tratados com mais aprofundamento no item sobre a evidência do corpo produtivo aliado ao corpo que também brinca.
} 
deles, eles listam uma média de 100 a 50 exercícios que possam influenciar positivamente aqueles fatores (Anexo 2).

Porém, os próprios trabalhadores percebem que para atingir o propósito de alteração orgânica - corporal seriam necessárias outras condições, tais como: mais tempo de prática, mais intensidade dos exercícios e maior regularidade, dentre outras que fundamentam um condicionamento físico individualizado que pretenda atender restritamente ao corpo biológico em sua possibilidade disciplinadora. Desse modo detectamos uma contradição entre o que a proposta veicula, pretende e propõe-se a atingir e o que de fato, acontece.

\subsection{A GINÁSTICA NA EMPRESA： ... UMA TECNOLOGIA ORGANIZADORA DO TRABALHO}

Compreendemos que essa exercitação corporal poderia ser expressão de um direito ao corpo (Covre, 1996); acrescentamos: de um corpo que também brinca. Exercê-la como um direito seria imprescindível para que esses trabalhadores a reconhecessem como uma tecnologia de trabalho, sendo solução para a execução de atividades que estão ultrapassando, corriqueiramente, os limites adequados para uma vida equilibrada e necessitando, por isso, de outros recursos para conseguir equilíbrio.

A implementação de máquinas tecnicamente avançadas nessa empresa não constitui novidade; porém na Fábrica $X$, não se liberaram os trabalhadores de atividades fatigantes. Observamos que essa fadiga está sendo amenizada pela presença desse componente inovador no expediente: programa de Ginástica na Empresa.

Uma idéia que se fez presente tanto nas palavras do gerente da Fábrica X, quanto nas dos coordenadores da ginástica do SESI, é que essa exercitação corporal orientada (a Ginástica na Empresa) traz benefícios tanto para o patrão quanto para o empregado (Anexos 1,2 e 3). Isso também é exposto para os trabalhadores nas palestras de sensibilização e foi afirmado por um deles: Os benefícios são tanto para o patrão como para o empregado (Anexo 6). 
Essa idéia, dos efeitos positivos da ginástica para ambas as partes, como uma benfeitoria, estava presente na avaliação de todos e foi por nós observada em praticamente todas as oportunidades que permitiam essa fala. Julgamos que essa prática de divulgar boas ações da empresa está bem próxima das propagandas e não se restringe à ginástica a eles oferecida. Isso parece consolidar uma forma constante de convencer os trabalhadores do protecionismo da empresa tais ${ }^{67}$ como: 'essa empresa é uma família, todos devem se sentir em casa e devem cuidar de tudo: máquinas, limpeza como se fossem seus.

Reportando-nos a essa tecnologia, vimos que não se trata de um benefício pessoal direto para o trabalhador, como já apontamos, mas de uma resultante que atinge o conjunto das relações internas de trabalho, ou seja, atende uma melhoria no processo interno do trabalho num sentido ampliado e não pessoal ${ }^{68}$, visto que apesar de individualmente o trabalhador descansar nesse momento de descontração, o que se atinge, no conjunto, é a produção eficiente e com excelente qualidade de motores elétricos.

Para os trabalhadores que fazem parte do grupo pesquisado e de acordo com as suas respostas sobre várias questões, vimos que o trabalho representa centralidade em suas vidas.

Todavia, a compensação pelo desgaste fomentado por esse tipo de trabalho, nas condições observadas, é necessária e se efetiva no sentido de atender ao corpo que dói, que está cansado e apresenta estresse, conseqüências sentidas pelos trabalhadores, conforme suas respostas. Afirmam, em sua grande maioria, que se sentem estressados e destacam o trabalho como o seu maior causador; o cansaço é o agente mobilizador dessa conseqüência.

Vejamos, a título de ilustração, a tabela a seguir:

\footnotetext{
${ }^{67}$ Dentro do galpão da Fábrica X, vimos pregados em cartazes esses dizeres e outros.

${ }^{68}$ Alivia o cansaço pessoal imediato, isso é verdade, mas, para a nossa análise, a questão colocada não é se isso é bom ou ruim, o objetivo proposto é o de ver qual o sentido que uma exercitação corporal tem no expediente de trabalho.
} 
TABELA 16 - Estresse

\begin{tabular}{l|c}
\hline \multicolumn{1}{c|}{ Você se sente estressado? } & Porcentagem \\
\hline Sim & 54,55 \\
\hline Sem resposta & 24,10 \\
\hline Sim e não & 4,40 \\
\hline Não & 16,95 \\
\hline Total & 100,00 \\
\hline
\end{tabular}

Ao procurarmos identificar os causadores desse estresse, constatamos que os trabalhadores entrevistados, em sua maioria, vinculam as causas, direta ou indiretamente, ao trabalho. É perceptível que a totalidade dos motivos está ligada de fato ao trabalho, funcionando como catalisadores de estresse. À pergunta sobre o que os estressava, responderam: É o trabalho que exige rapidez e muito esforço, preocupações. Outro afirma: quando estou fazendo o meu objetivo e vem alguém encher o meu saco. Seguindo com outras respostas:

...trabalho pesado e os motores;

... meus "amigos" no trabalho; os trabalhadores com quem trabalho;

... falhas no trabalho;

... o ambiente onde trabalho e a falta de dinheiro;

...ansiedade, horas a mais trabalhadas;

... excesso de trabalho e pouco espaço para colocar os materiais;

... os meus colegas de trabalho/alguns colegas de trabalho;

...trabalhar e estudar;

..excesso de trabalho;

... minha empresa

...tenho muita ansiedade,

...ataca a gastrite nervosa;

... a correria do dia- a- dia;

...falta de dinheiro e quando as coisas não dão certo;

...falta de dinheiro/sempre o mesmo trabalho;

...ficar o dia inteiro em pé;

...falta de dinheiro; trabalhar em pé sempre no mesmo lugar, na máquina 
Na tabela abaixo sintetizamos todas as respostas:

TABELA 17 - Motivos do estresse

\begin{tabular}{l|c}
\hline Quais os motivos do seu estresse? & $\mathbf{N}^{\mathbf{0}}$ de respostas \\
\hline O trabalho & 52 \\
\hline Não responderam & 46 \\
\hline Quando a comida não está pronta ao chegar em casa & 01 \\
\hline Estudar & 01 \\
\hline Pessoas da sociedade & 01 \\
\hline Ansiedade & 01 \\
\hline Preocupação & 01 \\
\hline Nervoso & 01 \\
\hline Violência & 01 \\
\hline Dormir pouco & 01 \\
\hline Indiferença & 01 \\
\hline Nada & 01 \\
\hline Sim & 01 \\
\hline Só no começo & 01 \\
\hline Falta de atividade física & 01 \\
\hline Não respondeu & 07 \\
\hline Total & 118 \\
\hline
\end{tabular}

Para compreender melhor as situações provocadoras de estresse e as causas, procuramos detalhar como eles se percebiam estressados e as causas desse estresse. Responderam o questionário 118 trabalhadores, destes, a maioria respondeu ${ }^{69}$ que o cansaço, a dor e o nervosismo (ligados à irritação, à ansiedade, ao desânimo e à tristeza) são as causas provocadoras de estresse.

O fato de que a maioria afirma que se sente cansada com o trabalho, e, de sua concepção de estresse dos entrevistados - o esgotamento total de suas energias - estar de

\footnotetext{
${ }^{69}$ Em detalhes temos: Cansado 16; Cansaço no corpo e dores de cabeça 03; Cansaço, fadiga 01; Cansaço, sem paciência 01; Cansaço, dor nos músculos e nervoso 01; Corpo cansado e dolorido 01; Dores nas pernas de tanto ficar em pé na empresa 01; Dores principalmente nas pernas 01; Dores nas pernas, cabeça e braços 01;Dores de cabeça e muito nervoso 01; Tontura e dores de cabeça 01; Nervoso, cansaço fora do normal 01; Nervoso por qualquer coisa, perdendo a calma com facilidade, qualquer coisa me irrita e fico nervoso facilmente 04; Nervoso, inquieto e revoltado 01; Sono e mau humorado 01; Sono, dores de cabeça e nas pernas 01; Por vandalismo 01; Na empresa, no ônibus 01; Quando pessoas que falam comigo e são grosseiras 01; Às vezes desanimado, dolorido etc 01; Acordo 3 h 30 e vou dormir à 11h da noite 01; Fico irritado, chato e com vontade de chorar 01; Brigo e discuto por pequenas coisas 01; Não consigo conversar 01; Fico com a mente muito agitada 01; Quando as coisas não dão certo 02; Com muito trabalho repetitivo 01; Não tenho motivo para tanto 01; Fico com a mente muito agitada 01; Cansado, nervoso 03; Cansaço físico e mental 02; Cansaço e desânimo 01; Cansaço psicomotor 01; Cansaço e preocupação 01; Dores de cabeça 01; Dores no corpo 02; Inquieto 01; Irritação 01; Indisposição 01; Desânimo 02; Nervosismo e impaciência 01; Nervoso/ Muito nervoso 07; Nervosismo, pressão alta, esgotamento nervoso 01; Aumenta a tensão nervosa 01; Quando estou
} 
acordo com as explicações existentes (Nahas, 1989 e Ramos,1998), indica que a ginástica como tecnologia contribui efetivamente para melhor organização do trabalho, pois, com ela, o cansaço relacionado e provocado pelo trabalho pode ser amenizado.

O estresse, na literatura acima, está explicado pelas noções de fisiologia, com algumas considerações sobre o aspecto psicológico. Esses autores divulgam que o fundamental para se viver bem, alcançar o equilíbrio orgânico e nos livrarmos do estresse, é ter os sistemas de funcionamento orgânico em homeostase, ou seja, em equilíbrio. Pois, ao nos defrontarmos com situações que alteram esse equilíbrio, que vai da alegria à tristeza, de problemas familiares à problemas no trabalho, o nosso organismo responde rapidamente de forma que o corpo se adapte às novas situações que provocam desequilíbrio. Tudo organicamente é modificado em função dessa necessidade de adaptação: há produção de hormônios que, ao entrarem na corrente sangüínea, alteram as várias reações bioquímicas, sempre em busca da normalidade do funcionamento orgânico. O problema incorre aí, pois se as situações promotoras desse desequilíbrio bioquímico forem prolongadas, causarão problemas tanto de ordem emocional, quanto física, na chamada fase de exaustão.

Existe um padrão de reações orgânicas chamado de síndrome biológica de estresse (Nahas, 1989, p. 59), caracterizada por: 1 - Reação de alarme (a pessoa mobiliza os mecanismos de manutenção da vida, o corpo resiste até certo ponto, fica em alerta); 2 - Fase de resistência (se o nível do estresse for superior à capacidade de resistência entra-se na fase de exaustão, comprometendo os canais específicos de defesa); e 3 - Fase de exaustão (os hormônios do estresse continuam aumentando e a adrenalina e a catecolamina, principalmente, geram sobrecarga dos canais apropriados de defesa). Nessa fase, a vida só será mantida se a capacidade de resistência for superior ao estresse.

A maior consequiência da permanência da fase da exaustão é a fadiga (o cansaço é o início). Assim, quando os trabalhadores percebem-se estressados é porque estão sempre cansados e, se a fadiga permanece, diminui a eficiência no trabalho. Isso se torna um problema, haja vista que a qualidade dos produtos fabricados e a produtividade exigida são metas inquestionáveis para esses trabalhadores. Sendo assim, a mais nova tecnologia que vem a favorecer a eficiência nesse trabalho não está em máquinas com comando numérico 
computadorizado, nem na microeletrônica em si, pois isso é conseqüência normal do desenvolvimento capitalista, mas está na solução para manter o corpo que produz com suas funções orgânicas equilibradas. Está em não perder a produtividade por não exaurir o corpo por completo. Esta nova tecnologia de organização do trabalho é fundamentada não em máquinas criadas pelo homem, mas nele próprio.

As principais características encontradas na prática dessa exercitação corporal circunscrevem-se no âmbito de uma ginástica compensatória, ou seja, uma exercitação corporal orientada, que oportuniza a prática de movimentos não solicitados pelo corpo - ou que estão sendo muito repetitivos - na rotina diária do seu trabalho, em que se gasta muita energia localizada. Essa energia é conseguida pelas combustões químicas que ocorrem nos músculos, porém, quando a atividade física é muito extenuante não possibilita ao corpo ${ }^{70}$, pela corrente sangüínea, conduzir os nutrientes necessários à sua manutenção e funcionamento adequados. Em qualquer atividade física exagerada em intensidade, há vários comprometimentos. O comprometimento das fibras musculares, por exemplo, acontecem com a diminuição de nutrientes em suas células, cuja consequiência mais direta é a fadiga. $\mathrm{O}$ sistema nervoso também se ressente, aliás, todo o corpo sente, haja vista que o corpo ${ }^{71}$ é um conjunto de dimensões que se conjugam numa mesma materialidade.

Essa Ginástica na Empresa (ginástica na linha ou ainda ginástica laboral, como é denominada) está sendo realizada para compensar a falta de exercitação completa do corpo, ou seja, parece que o corpo sente e reage negativamente em ter que ser considerado por partes; ele próprio faz a denúncia pelas dores, cansaço e doenças como LER e DORT, dentre outras.

Tudo indica que a capacidade técnica de repor o que foi gasto além do suportável pode ser amenizada com a ginástica. Entretanto, para que haja melhoria do estado geral da pessoa, outros componentes, que estão além do que a aparência expressa devem ser considerados. Um deles é o componente da subjetividade e que estamos denominando de não material. Esse elemento para nós está, no aspecto lúdico da ginastica, diretamente ligado à motivação visada pela empresa. Vincula-se também a esta idéia a valorização do ser humano,

\footnotetext{
${ }^{70}$ Falaremos mais sobre essa dimensão biológica no próximo item deste capítulo.

${ }^{71}$ Tentaremos esclarecer melhor essa questão do corpo no próximo item, considerando que a compreendemos como uma questão complexa.
} 
no sentido de aliar uma prática que possibilita expressões ${ }^{72}$ essencialmente humanas ao trabalho. Acrescentamos que se somos capazes de brincar, de relaxar e de se descontrair, certamente seremos menos estressados. E homens que expressam-se como seres capazes de rir, brincar, também, produz mais no trabalho.

Há um detalhe nessa tecnologia que a particulariza em relação às outras. Ela não se caracteriza como tecnologia de uma máquina que funciona do mesmo modo em qualquer lugar, mas é uma tecnologia em que os instrumentos são seres humanos que, apesar de toda a linearidade impostas pelas relações internas de trabalho - tudo aparentemente igual, todo dia fazendo a mesma coisa -, conservam individualidade na maneira de sentir e interpretar a ginástica.

Acolhemos respostas diferentes, é verdade, mas não antagônicas, nas entrevistas sobre a ginástica e o que ela estaria lhes proporcionando:

.. Mais disposição para o trabalho, fico mais leve, mais animado para o trabalho;

... Consigo dormir melhor, muito bem;

... Sinto menos sono e menos dores nas pernas;

... Durmo melhor, descanso mais e fico disposto no dia seguinte;

... Me sinto mais aliviado; mais leve; menos irritação; eu me acho mais forte e com mais saúde;

... Nenhuma, para a minha pessoa não houve diferença;

... Melhorou a amizade entre os amigos; mais ânimo, mais animado; mais disposição para trabalhar e no relacionamento com os colegas;

... Segurança no trabalho e mais disposição

Percebemos que as impressões destes trabalhadores com relação a essa prática são gerais e mais subjetivas, tais como de que a ginástica possibilita amizade, melhora o ânimo, mais disposição, como mais orgânicas dando a impressão que a ginástica alivia dores nas pernas, cansaço e a saúde.

\footnotetext{
${ }^{72}$ Aqui observamos que na prática dessa ginástica, se tem a impressão de que a pessoa que está ali envolvida pode de fato, se auto-expressar.
} 
Essa tecnologia vem organizando o expediente interno de trabalho de maneira combinada com a cultura da empresa. Procura ajustar o corpo que produz em sua dimensão biológica (material), de modo a influenciar positivamente e diretamente o clima organizacional do trabalho, ou seja, significa uma tecnologia a mais na propulsão da alcançada e permanente produtividade da empresa. As palavras do gerente confirmam esta afirmação: melhora o clima e o trabalho em equipe (Anexo 1).

Os cuidados ou precauções da empresa para com os trabalhadores (com seus corpos produtivos) estão explícitos em outras providências, tais como assistência médica e odontológica, serviço social e creches, só para citar algumas ${ }^{73}$, além da permanente preocupação em mantê-los motivados, na forma que eles acreditam ser a mais efetiva - a participação nos lucros. Essas medidas, além de permitirem uma alta produtividade, podem, simultaneamente, diminuir despesas advindas do absenteísmo, ou seja, a falta ao trabalho por doenças, o que ocasionaria um baixo empenho na produção. Dessa forma podemos sustentar a afirmação que, de fato, a empresa só tem a ganhar com a iniciativa de implantar a Ginástica na Empresa.

Perguntamos ao gerente da Fábrica $X$ o que a empresa lucrava com a implementação dessa ginástica e ele afirmou:

Não perdi produtividade, continuo fazendo o mesmo número de motores e até mais. Os benefícios vão acontecer daqui para a frente, a médio e longo prazo. A idéia é que estamos abertos para o novo, desde que o novo mostre resultado. A gente acredita que esse programa mostra resultado em médio e longo prazo (Anexo 1).

Essa ginástica vem melhorando o rendimento do corpo que trabalha, evidência encontrada na fala dos entrevistados, porque impede que ele se esgote por completo, evita exaurir todas as forças físicas e mentais. A proposta é que este corpo seja mantido em equilíbrio e com saúde ${ }^{74}$, para, adequadamente, manter- se produzindo.

Os trabalhadores na fábrica, ao serem questionados sobre o benefício que a ginástica proporcionava, de acordo com a tabela seguinte, responderam com argumentos vinculados, em sua maioria, à melhoria na disposição para o trabalho, vejamos:

\footnotetext{
${ }^{73}$ No Manual do colaborador essas medidas estão explícitas em maiores detalhes. Em síntese, esses itens estão expostos no Anexo 7.
} 
TABELA 18 - Efeitos da ginástica

\begin{tabular}{l|c}
\hline O que a ginástica lhe proporciona? & $\mathbf{N}^{\mathbf{0}}$ de respostas \\
\hline Mais disposição para o Trabalho & 27 \\
\hline Relaxamento (do trabalho) & 09 \\
\hline Alívio das dores (do trabalho) & 07 \\
\hline Quebra o ritmo de trabalho & 02 \\
\hline Melhora o trabalho em equipe & 01 \\
\hline Diminui o cansaço (do trabalho) & 02 \\
\hline Promove amizades (no trabalho) & 01 \\
\hline Mais disposição, menos cansaço e promove o lazer (no trabalho) & 02 \\
\hline Continua tudo igual & 01 \\
\hline Se sente bem (no trabalho) & 02 \\
\hline Está bom & 02 \\
\hline Resolve o problema da LER (provocada no trabalho) & 01 \\
\hline Aprende brincadeiras para levar para casa & 01 \\
\hline Melhorou o ambiente de trabalho & 01 \\
\hline Acaba o estresse (do trabalho) & 01 \\
\hline Não responderam & 58 \\
\hline TOTAL & 118 \\
\hline
\end{tabular}

Do ponto de vista da empresa e dos trabalhadores, o que a ginástica atinge, na realidade, é o processo de trabalho. Portanto confirmamos mais uma vez essa prática como uma tecnologia organizadora do trabalho.

Em outro momento perguntamos-lhes quando eles se sentiam com mais disposição para trabalhar. As respostas foram variadas e, apesar de ter sido insignificante o número de respostas que indicavam o momento seguinte ao da ginástica como o de maior disposição, a indicação do descanso como condição essencial para uma boa produtividade demonstra a percepção do trabalhador de que o cansaço prejudica o rendimento do trabalho. Vejamos a tabela a seguir:

\footnotetext{
${ }^{74} \mathrm{O}$ conceito de saúde utilizado por essa empresa não é um conceito ampliado, ou seja, que vá além da dimensão biológica.
} 
TABELA 19 - Disposição para o trabalho

\begin{tabular}{l|c}
\hline Quando você se sente mais disposto para trabalhar & Porcentagem \\
\hline Quando está descansado & 37,24 \\
\hline Quando gosta do que faz & 1,7 \\
\hline Tem que trabalhar, é o sustento & 0,83 \\
\hline Nunca pensou no assunto & 0,83 \\
\hline Quando volta de um feriado & 2,6 \\
\hline Quando ganha aumento & 0,83 \\
\hline Quando faz ginástica & 6,7 \\
\hline Quando dorme bem & 5,83 \\
\hline Depende & 0,83 \\
\hline Sempre & 14,16 \\
\hline Depois do lanche & 0,83 \\
\hline Quando está no meio da semana & 3,34 \\
\hline Quando está perto do final de semana & 5,9 \\
\hline Quando está sem problemas & 5 \\
\hline Antes do almoço & 1,7 \\
\hline Quando está com saúde & 2,5 \\
\hline Nunca está disposto & 0,83 \\
\hline Quando está em casa & 1,7 \\
\hline Quando não sofre pressão & 0,83 \\
\hline Não sabe responder & 0,83 \\
\hline Quando o clima está agradável, não está quente & 0,83 \\
\hline Quando não está de ressaca & 0,83 \\
\hline Quando o trabalho vai bem & 0,83 \\
\hline Não responderam & 2,5 \\
\hline Total & 100,00 \\
\hline
\end{tabular}

Essa tabela evidencia que as condições para um bom desempenho no trabalho estão diretamente relacionadas ao estar descansado, qual seja: quanto mais descansado está o trabalhador maior será seu rendimento. Percebemos que, realmente, a ginástica pode contribuir para a promoção do descanso, de um certo bem-estar físico necessário à boa produtividade no trabalho.

A Ginástica na Empresa entra na fábrica e está explicada pelo seu caráter de utilidade e como reparadora das tensões adquiridas nas relações estabelecidas entre o corpo que produz excelentes motores e, também, quer brincar, e precisa descansar. Ela vem funcionando como manutenção e ajustamento de uma máquina muito mais complexa do que as de comando numérico computadorizado. Vale dizer que, por não ser fácil a manutenção do ser humano, ininterruptamente, produzindo, exige-se o atendimento a algumas necessidades específicas, que estão ao mesmo tempo, ligadas às dimensões biológicas e às dimensões 
sociais (históricas, culturais). Sabemos que, se não existir essa manutenção, a produtividade cai e essa situação não é de interesse da empresa, como bem expressa o seu gerente.

$\mathrm{O}$ próprio gerente da Fábrica $\mathrm{X}$ reforça ao afirmar que para garantir a produtividade, a empresa não contrata mais pessoas para trabalhar, mas procura acertar os problemas das que já estão contratadas. Vale dizer para garantir a boa produtividade é preciso garantir o bom desempenho dos trabalhadores já inseridos na produção ao invés de se preocupar em aumentar o número de empregados para que cada um precise trabalhar menos e se cansar menos.

Quando perguntamos sobre as consequiências da ginástica para um trabalhador, ele disse: [...] para o desenvolvimento físico nem tanto, mas para a parte que a gente está sempre estressado e se preocupa só com a produção, produção, nessa hora a gente pára para relaxar um роисо.

Ainda que o programa venha como um pacote tecnológico pronto, na prática, acrescentam-se vários exercícios de alongamento, exercícios em dupla e brincadeiras promotoras de interações e contatos; enfim, ações mais centradas na ludicidade ${ }^{75}$ do que no rendimento físico.

Constatamos que o exercício de alongamento conjugado a essas brincadeiras, realizados no momento da ginástica, pode contribuir para uma melhora significativa dos movimentos que os trabalhadores realizam na própria atividade laboral. A solicitação permanente para eles é de aspectos ou dimensões neuro-fisiológicas, mas, com ênfase na atenção e concentração, em síntese: no rendimento produtivo. Para existir esse rendimento, faz-se necessário que o corpo esteja equilibrado e disponível em sua totalidade. Ao movimentarem o corpo em outras dimensões, compensatoriamente, haverá uma recomposição $\operatorname{orgânica}^{76}$.

Detectamos a presença de uma postura ritualística em relação à prática da ginástica, por parte dos executantes. Eles conseguem separar nitidamente o momento da

\footnotetext{
${ }^{75}$ Compreendemos que o lúdico é um conceito complexo, porém o estamos entendendo como aquela atividade que busca, unicamente, a alegria, a satisfação imediata, o sentir agradável, o estímulo à imaginação, à fantasia e que se consome nela mesma.

${ }^{76}$ Explicaremos com mais detalhes essa necessidade de recomposição orgânica no próximo item.
} 
realização da ginástica, como se fosse um rito de passagem do mundo de fora para dentro da fábrica, ou seja, eles exercitam bem a concentração. Isso na ginástica preparatória ou no momento do intervalo, da mudança daquela repetição constante de movimentos para outros de descontração e relaxamento, no momento da ginástica compensatória.

É nítida a distinção que aprenderam a fazer ao considerar a hora da Ginástica como o momento da descontração necessária para se desligar do cotidiano, lá de fora e de dentro da fábrica também e o momento do trabalho. Na Ginástica desligam-se de tudo que pode atrapalhá-los. Realmente há uma postura compenetrada no início a ginástica, mas com as brincadeiras e o relaxamento depois dos alongamentos musculares, os participantes vão se descontraindo. Nas palavras de um entrevistado: Fazemos mais amizade porque os trabalhadores se falam mais, conversam. Outro afirma: Nos conhecemos e com isso ficamos mais unidos.

O toque é um elemento que diferencia a Ginástica dos outros modelos da ginástica ${ }^{77}$ que a educação física veicula, acrescentando, sem dúvida, uma nova referência de exercitação corporal. Cotidianamente, eles estão naqueles oito, dez ou doze minutos diários repetindo um gesto que pode representar afetividade em relação ao outro, relembrando, de alguma forma, a existência deles como seres humanos e não somente como eficientes produtores de motores elétricos, como mais uma máquina produtiva.

Foram observados, no terço final da aula, movimentos de toque, dois a dois, sempre com massagens ou tapinhas nas costas, um do outro, ou, ainda, com exercícios que exigiam segurar os braços um do outro, ou fazer força contra o outro.

Apesar destas práticas e da maioria dos modelos de ginástica, muitas vezes, estarem muito próximos a um adestramento, percebe-se uma orientação educativa e com algo de novo, além das alterações no pacote que já vem pronto. O problema é que não está acontecendo a exploração devida para esse caráter educativo, haja vista que os facilitadores só repassam o que está desenhado na planilha recebida da coordenação do SESI, e não dispõem de formação específica para tal fim. Assim não há como os trabalhadores desenvolverem nenhum tipo de ação pedagógica. Vale dizer que se limitam a um tipo de ação mais

\footnotetext{
77 Marinho (s/d)
} 
adestradora - a repetição automática dos movimentos, pois uma ação pedagógica, sem dúvida, solicita outras informações além da repetição do que está exposto numa planilha.

Os desdobramentos de outras ordens - os subprodutos, nas palavras do gerente geral da Fábrica $\mathrm{X}$ - que essa ginástica proporciona, principalmente os que estão relacionados com a melhoria do clima organizacional do trabalho pela via dos componentes subjetivos, constituem algo a ser mais aprofundado e sistematizado teoricamente ${ }^{78}$.

Da Ginástica observada, pudemos concluir que é uma mistura de movimentos bem próximos da calistenia, mas distingue-se dela. A ginástica calistênica é a utilizada nos quartéis, e seus traços principais são: repetição dos movimentos, a contagem dos exercícios em voz alta pelos executantes, a disposição do grupo em colunas e fileiras, um mestre à frente como modelo e todos repetindo os seus movimentos (Marinho, s/d).

Contudo, a despeito das semelhanças gerais com este modelo de ginástica há diferenças nos tipos de exercícios corporais que são planejados para serem executados, tais como os alongamentos e o toque, elementos que jamais seriam permitidos num quartel. A disposição não é em fileira, mas sim em círculos, e o grupo é pequeno - outra diferença da calistenia, que geralmente comporta muitos trabalhadores enfileiradas e em colunas. Além disso, existem brincadeiras entre os movimentos e há, intencionalmente, segundo a coordenadora do SESI, situações de práticas corporais que objetivam o contato entre eles.

Considerando-se apenas a dimensão biológica do movimento, o alongamento é um exercício que procura aumentar a extensão dos músculos para que eles possam se descontrair, descongestionar as tensões, que não são mais do que contrações contínuas, que causam a redução do seu comprimento. Um músculo sempre contraído, depois de algum tempo nessa condição, encurtará o tamanho de sua fibra. Quando a fibra muscular está curta é possível aumentar o volume desse músculo, mas o movimento torna-se também curto e limitado.

As conseqüências desta Ginástica, apesar de não estarem definidas a priori, - ou seja, dada a ênfase na fala dos trabalhadores nas questões afetivas, e no alívio das dores e do cansaço corporal - são de beneficiar e promover bem estar aos trabalhadores, com isso, 
contribui para um clima organizacional de trabalho mais propício a uma atividade menos estressante e mais rendosa para a empresa, pois diminui as baixas ambulatoriais e ainda assegura uma eficiente produtividade.

As dores corporais ocasionadas pelo alto grau de solicitação física da atividade laboral foram parcialmente sanadas. Poucas respostas foram contrárias a essa melhora. Houve, ainda, melhora da integração entre eles, criando uma espécie de convívio social, oferecendo oportunidade de conhecer mais o colega ao lado. Essas explicações estão presentes nas respostas de um grande número de entrevistados: ...Alterando pouca coisa, ajuda a dar uma relaxada, dar uma distraída, melhora a convivência aqui entre os amigos;...De bom que dá é mais disponibilidade para a gente, a gente não sente tanta dor e ruim não tenho nada para falar (Anexo 6).

Vemos assim que há, advindas da Ginástica para além do componente fisiológico, consequiências positivas de aspecto subjetivo, nestes trabalhadores. Eles afirmam que esses exercícios de alongamentos são bons, contudo não conseguem especificar em quê. As pessoas entrevistadas nos responderam que essa exercitação corporal promove descanso, maior integração entre a equipe de trabalho, maior interação social e intervalos do trabalho cansativo que realizam. Exemplificamos com a fala de um trabalhador: Tanto no trabalho que dá mais motivação, quanto em mais amizade com o pessoal, porque muitos trabalhavam longe um do outro

Para a empresa, a organização interna do trabalho está montada tendo em vista o alcance de uma maior produtividade. Para os trabalhadores, apesar de perceberem a utilidade funcional da ginástica, eles demonstraram, com clareza, em suas respostas, que ela não passa de uma reposição de energia. Essa reposição pode ser devida simplesmente à interrupção do ritmo de trabalho e não pela própria ginástica. Essa constatação está presente na fala da $2^{\mathrm{a}}$ coordenadora do programa local. Perguntamos se eles gostam: [...] Eles gostam e daí eles querem colocar coisas e querem mudar coisas que não é possível. Tipo: eles querem que haja exercícios todos os dias diferentes, eles querem que mude a série toda semana e isso não tem como fazer porque foge do meu controle, eu expliquei isso para eles. Eles estão solicitando isso nas reuniões dos facilitadores? Sim. Querem a ginástica diferente todos os dias? Acham que está muito repetitivo. E você foi saber por que eles querem mudar? Na verdade sabe qual é a impressão que me dá? é que por alguns, pela grande parte, eles querem a ginástica para

\footnotetext{
${ }^{78}$ Apesar de estarmos constatando empiricamente, na área da Educação Física, não dispomos de sistematização
} 
ficar os dez minutos sem fazer nada. Por isso que a ginástica tem grande aceitação, não é por causa do exercício, eu vejo isso. É um espaço que tem para um descanso? De descanso, eles querem na verdade isso. E daí eu coloquei para eles que é válido o descanso nos dez minutos, só que vocês vão voltar para o trabalho cansados do mesmo jeito e com a ginástica não, vocês vão voltar mais estimulados, eu falei isso para eles (Anexo 3).

Percebemos, nesse sentido, que esses trabalhadores, quando têm oportunidade para intervir, falar, participar, estão dispostos a isso; no entanto, nesse espaço que está sendo criado para exercitação corporal, isso é só uma impressão, parece uma atividade em que eles podem intervir. Vale dizer, essa prática parece ser de interação dos trabalhadores em que eles poderiam se auto-expressar, porém, tornou-se nítido esse limite, quando estes sugerem alterações na dinâmica das aulas que não podem ser efetivadas. Existe um modelo a ser seguido que não autoriza grandes mudanças.

Observamos, em uma das reuniões com os facilitadores e a coordenadora do programa do SESI, que o enfoque das análises estava no levantamento de problemas percebidos por eles, contudo, as soluções encaminhadas pela coordenação eram dirigidas ao modelo já definido anteriormente. Por exemplo, eles avaliaram a não participação de colegas nas sessões e, a partir desse fato, iniciaram a discussão de como resolver isso, tendo em vista que o interessante é que todos participem, ou seja, podem acontecer mudanças periféricas e não substanciais. Eles realizam uma avaliação, porém, limitada ao que está posto e não a partir das impressões e vontades dos protagonistas dessa prática.

A domesticação ou disciplinarização do corpo, como diria Foucault (1986), não está unicamente na dimensão material, corporal, da pessoa. A obediência e a submissão não estão subsidiadas apenas nesses termos, ou seja, a condição de subordinação do ser humano à necessidade de prover a sua vida e a de seus familiares com o atendimento mínimo para a sobrevivência é que pode contribuir para essa docilidade. Como nos diz um entrevistado: temos que trabalhar, e quando perguntamos por quê, ele afirmou categoricamente: porque preciso, é o sustento. Problematizamos mais e afirmamos: se você não precisasse trabalhar, você trabalharia? Ele responde: não, se recebesse o salário sem trabalhar eu não ia [...]. Insistimos: ia fazer outra coisa? ele diz: sim, ia ficar em casa fazendo outra coisa (Anexo 6). 


\subsection{A EVIDÊNCIA DO CORPO NA TECNOLOGIA ORGANIZADORA DO TRABALHO: PRODUTIVIDADE, CANSAÇO, DOR E PRAZER}

É importante ressaltar que não consideramos o corpo separado da mente. A ênfase na palavra corpo justifica-se tendo em vista o grau de solicitação e a evidência que a ele é dada nesse tipo de trabalho, que é a montagem de motores elétricos de médio e grande porte. Apresentamos aqui uma tentativa de relacionar questões considerando mais a dimensão material, concreta do ser humano, num ambiente interno de trabalho. Por outro lado, entendemos que dessa forma poderemos exprimir tanto as possibilidades de produtividade do ser humano, em condições adequadas, quanto como essa intensidade nesse trabalho lhes ocasionam cansaço, dor, e como isso compromete o rendimento do trabalho do corpo que produz.

Com prazer e alegria também é possível sustentar a produtividade, porém, tais manifestações nessa tecnologia, torna-se difícil de analisar, haja vista que a relação entre o corpo que produz e o que brinca, a partir da mesma materialidade, não está equacionada teoricamente.

Existe uma preocupação, tanto por parte dos responsáveis pela implementação dessa tecnologia na empresa quanto pelos que a vendem, centrada nas dimensões biológicas do corpo. A busca de controle sobre ele visa a manutenção do rendimento. Vale dizer, para que não se interrompa a produção no trabalho por limitações físicas, o equilíbrio orgânico é notavelmente incentivado. Nesse sentido, os dois componentes cruciais e fundamentais dessa tecnologia empenham-se na busca do equilíbrio orgânico e a conseqüente produtividade num ambiente de trabalho em harmonia. Dessa forma, para alcançar o proposto, é necessário um corpo que produza com eficiência e qualidade exemplares (produtos sem defeitos) e, ao mesmo tempo, um corpo que saiba se descontrair, relaxar, brincar, desligando-se daquela realidade tão tensa, repetitiva e cansativa do trabalhador, como afirmaram alguns deles.

Identificamos que o objetivo é alcançar, do corpo que produz, produtividade sem desgaste funcional (orgânico) e, do corpo que brinca, a descontração, o relaxamento do corpo que produz, justamente para mantê-lo produtivo. Nessa unidade, na junção dessa polaridade, encontramos um mesmo corpo. Aquele que produz é o mesmo que brinca, porém as 
explicações encontradas estão subsidiadas somente na dimensão fisiológica do corpo produtivo. Para os coordenadores do programa só se consegue a identificação das conseqüências práticas que não estão restritas apenas ao corpo, porém, ainda não há explicações teóricas que possam garantir subsídios mais precisos.

A relação do biológico com o social constitui-se num desafio de grande porte. Procuramos correspondência entre o domínio da natureza e o da cultura, do histórico, no sentido de compreender a educação do corpo orientada pela ginástica e que pode produzir corpos dóceis, produtivos, e a possibilidade da desvinculação desse adestramento ao acrescentar outros elementos de expressão, além do rendimento produtivo. Dessa forma, levamos em consideração, nessa pesquisa, uma conseqüência prática que ultrapasse dimensões puramente fisiológicas do corpo.

O viés biológico constitui-se numa tecnologia organizadora do trabalho e contribui não somente nessa dimensão corporal, mas, também para a melhoria da organização interna do trabalho, utilizando-se do corpo de forma direta para que, indiretamente, pelas dimensões subjetivas, atinjam- se outros elementos.

Vale a pena conferir esta consideração nas palavras do coordenador geral do programa em Santa Catarina, quando lhe perguntamos se as questões subjetivas também são avaliadas, ele respondeu:

Também são avaliadas. Como a questão de subjetividade não é muito palpável, depende muito da qualidade do professor que está lá na ponta. Alguns fecham os olhos para isso, mas há outros que fazem o melhor trabalho. No caso da coordenadora que está lá na [...] ela está preocupada com isso, acaba se dando conta que algumas questões precisam ser trabalhadas, principalmente para o bom desempenho do programa (Anexo 2).

Por ele já ter sido coordenador do programa, observou in loco uma alteração não tanto biológica, mas no clima organizacional do trabalho. Explica ele:

Talvez isso tenha sido levantado por conta de uma dificuldade encontrada. Nós não dispúnhamos de formas para medir alguns dados mais subjetivos. Tendo nos despertado para ficar mais sensível, percebemos outras coisas, e, ao tentar medilas, vimos que a única garantia, hoje em dia, que nós temos para a efetivação de um programa melhor é perceber a alteração no clima organizacional da empresa. Essa parada que a gente faz no meio da jornada de trabalho ajuda nessa melhoria, principalmente porque a grande maioria das empresas hoje trabalham com 
produção individual também. Tem prêmio por produtividade, os trabalhadores esquecem que têm um vizinho com problemas, e que a gente também tem problemas, e passam a trabalhar também como máquinas. É uma exigência até da própria empresa uma produção mínima que tens de atingir (Anexo 2).

$\mathrm{Na}$ área da educação física, há explicações fisiológicas para o corpo em situação de rendimento, vinculadas à busca da aptidão física ${ }^{79}$ e ao esporte de alto nível, o esporte das Olimpíadas $^{80}$. Os aspectos mecânicos seguem os mesmos parâmetros. Esses aspectos ou dimensões fisiológicas ou mecânicas são visíveis, materiais, como já anunciamos e, portanto, passíveis de serem medidos; já os que dizem respeito aos sentidos são difíceis de medir. Estas dimensões estão apenas identificadas, portanto, iniciando os primeiros passos de uma elaboração teórica. Disso resulta a dificuldade para explicar uma exercitação corporal, a Ginástica na Empresa, no expediente de trabalho que, apesar de estar sendo justificada em termos fisiológicos, na prática atinge muito mais do que a dimensão puramente orgânica e mecânica de um corpo em si e do trabalho para a empresa.

À medida que o mental se identifica com o social, as mensagens sendo radicadas em um mesmo código geral e o sistema de significação sendo de natureza inconsciente, como afirma Freud (apud Rodrigues,1980), podemos promover a assimilação de um sistema de representações com esta prática corporal. Poderemos forjar códigos de manifestação social, cujas expressões vinculem-se ao adestramento, produzindo, assim, corpos dóceis, necessários à maior produtividade. Também poderemos contribuir com o estímulo de expressões que se vinculem ao corpo que também brinca, necessários a uma vida mais prazerosa, menos desgastante e sem preocupação com produtividade.

O corpo que é evidenciado nessa ginástica é o mesmo que produz e que brinca, como já foi afirmado. Essa relação, porém, está permeada por contradições; as explicações dadas para a existência dessa ginástica no interior do expediente do trabalho são de cunho fisiológico, porém existem consequiências de cunho psicológico e social (subjetivas). O corpo de uma pessoa é o mesmo para tudo. As fragmentações, porém, na estrutura social repercutem de qualquer forma no corpo individual: no corpo que trabalha e que brinca.

\footnotetext{
79 A crítica a essa produção foi desenvolvida por vários autores, dentre eles, Castellani Filho (1988), Medina (1983 e 1987), Bracht (1992), Coletivo de Autores (1991).

${ }^{80}$ Nesse sentido ver trabalho de Kunz (1994).
} 
Para entendermos esse domínio do aspecto fisiológico sobre o ser humano a limitação desta concepção, buscamos conhecer a origem da ginástica em suas inserções históricas.

Soares (1998) explica que a história da Educação Física no Brasil possui em suas raízes influências higienistas, que concebem as exercitações corporais como uma alternativa de depuramento de raça, e da raça branca, convém frisar. Essas práticas estiveram vinculadas à busca da saúde, o que associa a educação física à ginástica como uma prática de higienização, de limpeza, dando prioridade à utilidade fisiológica. Outra influência é a da ginástica militarizada, principalmente, a calistenia (Bracht, 1992, Castellani Filho, 1988). Essas são as bases gerais, a herança que temos da inserção da educação física na escola a partir do que houve, temos repercussões ${ }^{81}$ de várias ordens, até os dias de hoje. O conhecimento sistematizado que se tem e a prática que acontece em seus variados campos (escola $^{82}$, clubes, academias de ginástica e outros espaços) expressam os traços principais dessa história: a busca de aptidão física e da saúde em uma perspectiva unicamente biológica.

Consolidadas essas influências e aderindo-se com bastante facilidade aos conhecimentos produzidos a partir do corpo em situações que solicitam rendimento físico, bem como a conexão com a prática dos esportes de alto nível, ou o esporte competitivo - leiase do modelo olímpico (Kunz, 1991) -, a educação física ainda não consegue responder a essas novas solicitações.

Partindo dessas influências, buscamos outras compreensões e conhecimentos que permitissem explicar uma ginástica, uma exercitação corporal educativa numa fábrica, que evidenciasse claramente outras dimensões além do fisiológico. Assim, reafirmamos, nessa

\footnotetext{
${ }^{81}$ As maiores repercussões, a meu ver, dirigem-se à questão da dificuldade em equacionarmos o problema dos elementos materiais e imateriais, haja vista que a concepção de ciência predominante une-se à facilidade da quantificação em sua orientação epistemológica positivista. Com isso podemos limitar o avanço das questões que a prática social está apresentando. Sabemos que a linha positivista de produzir conhecimento só valida o que pode ser medido e quantificado. As dimensões imateriais, apesar de percebidas, são deixadas de lado.

${ }^{82}$ Segundo Bonetti $(1999$, p. 24) a dificuldade para a elaboração de um corpo de conhecimentos que possa dar conta de reflexões mais críticas para a prática pedagógica da educação física localiza-se também, além da identificação desta como instrução militar, numa concepção desta atividade como puramente prática. Ao mesmo tempo em que existe a herança da educação física como instrução militar esta coordena-se com outra herança pautada nos métodos ginásticos, métodos estes de origem Européia e Americana. Estes métodos ginásticos destinavam-se à formação de homens fortes, robustos, saudáveis e de bom caráter para defender a pátria. $\mathrm{O}$ desenvolvimento corporal deveria ser atingido através de exercícios analíticos (evidenciando o corpo por partes), corridas e saltos. Para o professor, a responsabilidade era de apenas apresentar os exercícios, dirigí-los e manter a ordem e a disciplina.
} 
perspectiva, a relação entre as solicitações que estão sendo feitas nas condições daquele tipo de trabalho (intensa produtividade) e a preparação dos trabalhadores para esse fim. Isso significa que a tecnologia da Ginástica na Empresa atende perfeitamente aos desígnios destas solicitações: o equilíbrio orgânico fisiológico.

Nas palavras de Foucault (1986), um corpo produtivo, obediente e submisso é um corpo domesticado, disciplinado. Porém vimos que essas marcas parecem não ser definitivas, pois apesar de serem impressas pela estrutura social e configuradas em uma realidade, pelas relações de trabalho, não são perceptíveis como algo material que esteja demarcado no corpo e que assim possa expor uma imagem própria desta sociedade. Por outro lado observamos que o mesmo corpo produtivo e disciplinado também se descontrai e brinca, então a via não parece de mão única.

Ora, o corpo domesticado e disciplinado expressa-se pela obediência e condescendência ao conjunto das regras sociais que o mantêm produzindo. Não existindo como identificar a domesticação ${ }^{83}$ de um corpo. Não o entendemos como expressão de uma vontade pessoal, individual, mas como expressão das condições sociais existentes, num conjunto de relações variadas. Nas relações de trabalho a que esses trabalhadores estão submetidos, por exemplo, as marcas que vislumbramos foram as de cansaço, de dor e também de prazer, de alegria, de satisfação; capacidades variadas que, para se expressarem, só esperam oportunidade. Ou seja, nesta exercitação corporal no expediente de trabalho, cabe considerar o corpo como templo, não do pecado - como diria Platão -, mas como templo também do lúdico, do corpo que brinca, da alegria, da vitalidade e de produtividade.

A Ginástica na Empresa, como tecnologia organizadora do trabalho, fundamentase na evidência desse corpo multifacetado e cheio de nuances imperceptíveis no imediato.

Os trabalhadores entrevistados assustaram-se quando lhes perguntamos sobre seus corpos. Tanto os homens como as mulheres reagiram da mesma forma. Que compreensão de corpo eles têm? Elaboramos, a partir das respostas deles, um panorama demonstrando o ponto de vista que predomina. Destacamos os pontos de vista predominantes: os que se percebem

\footnotetext{
${ }^{83}$ A crítica realizada para a ginástica dos quartéis ou a militarizada é centrada em Foucault (1986) quando ele explica como a disciplinarização dos corpos é uma forma de domesticação e com isso os submete a uma relação submissa ao poder. Afirma esse autor que todo corpo que é passível de disciplinarização pode ser um corpo
} 
numa totalidade, os que se percebem divididos e os que se percebem numa dimensão imaterial, ou seja, priorizam razões subjetivas.

Vejamos a tabela:

TABELA 20 - Compreensão de corpo

\begin{tabular}{l|c}
\hline Panorama da compreensão de corpo & $\mathbf{N}^{\mathbf{0}}$ de respostas \\
\hline Dimensões subjetivas & 03 \\
\hline Tipo de Personalidade & 02 \\
\hline Insatisfação com o corpo & 03 \\
\hline Não sabem & 02 \\
\hline Estético & 01 \\
\hline Para o trabalho & 46 \\
\hline Totalidade & 10 \\
\hline Todo & 48 \\
\hline Divididos & 05 \\
\hline Do ponto de vista biológico & 120 \\
\hline Partes/fragmentado & \\
\hline Não Respondeu & \\
\hline Total & \\
\hline
\end{tabular}

Existem e permanecem as influências biológicas, funcionais e as fragmentações; mas essa preponderância do ponto de vista biológico ${ }^{84}$ não é fruto também do histórico?

Conhecer o corpo não é somente conhecer os músculos, os ângulos de ação, o seu funcionamento fisiobiológico. A questão não é simples e torna-se complexa à medida em que deparamos com uma problemática ${ }^{85}$, em que a busca de respostas recai num campo mais psicanalítico.

Para Rodrigues (1980, p. 4) a possibilidade de entendermos as questões que estão imbricadas, tanto no pensamento quanto no corpo, supõe que "todo fenômeno psicológico é, em certo sentido, um fenômeno sociológico, à medida que o mental, por discrepância ou por conformismo, se identifica com o social".

dócil. No aspecto da possibilidade de docilização dos trabalhadores através da domesticação corporal, vimos que ela não está se dando por essa via única.

${ }^{84}$ Queremos deixar claro que não desconsideramos as dimensões biológicas, no entanto, estamos tentando chamar a atenção sobre a limitação de análises que reduzem todas as explicações corporais por essa única via.

${ }^{85}$ Ao relacionarmos o corpo biológico ao social, o corpo e a mente, aprofundamos a dificuldade vislumbrando mais uma vez que, apesar dessa temática a cada dia crescer mais no ambiente acadêmico, tornando-se objeto de estudo sob diversas orientações científicas, o mapa ainda está sendo montado; o corpo que brinca corrobora essas palavras. Ainda temos muito de amadurecê-lo teoricamente. 
Pois "não se podem compreender as práticas do corpo enquanto realidades simples e homogêneas, mas, sim, no entrecruzamento dos múltiplos elementos econômicos, políticos e culturais de uma totalidade" (Crespo, 1990, p. 8). O corpo sendo apenas uma parte desse todo, depende dele para extrair o seu sentido.

Tentamos avançar algumas posturas, principalmente a da perspectiva de Foucault (1986) ao considerarmos que existem várias nuances num mesmo corpo e, ao mesmo tempo em que um corpo é passível de docilização, a sua disciplinarização e obediência, ele pode conter e expor elementos de resistência, que podem formatar novas culturas corporais, aliando a isso novas "expressões”, não tão dóceis quanto as canalizadas, por exemplo, estritamente à produtividade.

Deparamo-nos com uma situação em que se consegue perceber o que está amadurecendo no conjunto das relações, porém, ainda sem estatuto científico que acompanhe paralelamente a problemática com explicações adequadas, superação e avanço teórico sobre as questões identificadas e suas contradições. Existe necessidade de uma teorização de uma exercitação corporal que solucione seqüelas que atingem o trabalhador individualmente e que são, de alguma forma, denunciadas pelo próprio corpo, porém, ainda, sem tradução exata que possa dar conta de uma perspectiva que vá além do ponto de vista fisiológico, na prática dessa ginástica.

Nesse sentido, tendo por base uma perspectiva fisiológica, buscamos dar conta pelos fundamentos teóricos sobre o corpo que produz e que brinca, levando em consideração que as consequiências percebidas no processo interno desse trabalho realizado na Fábrica $X$, originam-se e expressam-se também por essa via e, ao mesmo tempo, como a solução encontrada não está na riqueza de uma recomposição orgânica que inclui e evidencia o corpo que brinca.

\subsubsection{A TECNOLOGIA NO CORPO QUE PRODUZ E QUE TAMBÉM BRINCA}

A tecnologia organizadora do trabalho da Ginástica na Empresa abarca a relação entre o corpo produtivo e o que brinca no corpo concreto e a possibilidade de essa exercitação 
corporal assumir o modelo de uma cultura não somente disciplinar e adestradora, mas que considere e pretenda, no corpo concreto, expressões de alegria e descontração.

O corpo produtivo é entendido como o corpo útil ou nas palavras de Rodrigues (1980), a consideração da dimensão funcional é a que se dirige para o aspecto do biológico, e, acrescentamos que um corpo produtivo, que rende, também pensa e também brinca, ao ser solicitado e ensinado.

No que se refere aos aspectos fisiológicos, sabe-se que as capacidades físicas de força e de resistência, necessárias a esse tipo de trabalho, para estarem em seu potencial máximo de funcionamento, precisam de alguns requisitos essenciais adequadamente atendidos, pois os movimentos do corpo absorvem essas influências e geram o desempenho bom ou ruim.

Segundo Schmolinsky (1982), a sustentação e o movimento do corpo são responsabilidades dos músculos, e o comando é de responsabilidade dos impulsos originados no sistema nervoso. Para contrair os músculos, precisamos desses impulsos e quanto mais e em menor tempo eles chegarem aos músculos, mais rápidos e mais fortes serão as contrações que gerarão a força. Ainda, segundo esse autor, esses impulsos provêm de duas regiões do cérebro: a piramidal e a extrapiramidal. Os impulsos que vêm do trato piramidal são respostas conscientes, voluntárias. Os que vêm do trato extrapiramidal (e de certos tratos estriados) são os estímulos automatizados (caminhar, por exemplo).

Interessa-nos aqui compreender que há estágios diferentes na estimulação corporal, no aprendizado de certos movimentos. Num primeiro instante, a pessoa realiza aquele movimento de forma consciente, pelos impulsos piramidais e quando consegue a automatização é o trato extrapiramidal que está informando. Porém, mesmo quando os movimentos já estão automatizados, segundo Schmolinsky (1982, p. 47), eles são controlados pelo sistema motor. Vale dizer, "o sistema motor registra as condições em que os movimentos normalmente se efetuam". Nas condições de trabalho que analisamos, também existe a assimilação motora por parte de quem executa aqueles mesmos movimentos diariamente.

As contrações musculares responsabilizam-se pela produção da força e, além dos impulsos nervosos, para que isso aconteça é necessário energia oriunda da decomposição do 
ATP (adenosina-trifosfato), que se encontra acumulado nos músculos e fígado (glicogênio), porém em pouca quantidade, tendo de ser ressintetizada continuamente. Cabe lembrar que todos os nutrientes necessários ao sistema celular do organismo são trazidos pelo sangue, como também os resíduos que nele são metabolizados. Enfim, a alimentação dos músculos é feita pela circulação sangüínea pelo coração, que é o motor que movimenta tudo isso.

O oxigênio também possui um importante papel nesse processo, sendo responsável pelas combustões químicas, as quais acontecem também nos músculos, durante a execução das atividades motoras. No caso de uma atividade que exige bastante força física, como a montagem dos motores elétricos da Fábrica X, essa situação é constante.

A repetição continuada dos movimentos, num esforço prolongado, faz com que exista uma necessidade bem maior de oxigênio para a devida combustão.

Dado o consumo acentuado de energia e o baixo nível de glicogênio que se tem acumulado nos músculos e no fígado a carga desse elemento é rapidamente gasta com a execução dos movimento. Assim haverá urgência de nova sintetização desses elementos no organismo, sem o que fatalmente, a exaustão ${ }^{86}$ instalar-se-á. Para que haja um bom acesso desses nutrientes é preciso ativar a circulação, pois o "sangue irriga todos os órgãos do corpo e leva-lhes as substâncias nutrientes (como, por exemplo, o glicogênio), que estavam armazenadas noutros órgãos e que lhes são necessárias para as suas funções (como, por exemplo, as musculares)" (Schmolinsky, 1982, p. 48).

Ainda segundo o mesmo autor, a atividade do sistema cadiovascular é comandada por nervos que, de acordo com as necessidades do organismo, aumentam o débito cardíaco(maior quantidade de sangue expelida num dado intervalo de tempo) e dilatam os vasos. O simpático e o parassimpático, ou vago, são os dois sistemas de nervos responsáveis por essa função reguladora. O simpático é também designado por "sistema ativo" e o parassimpático por "sistema recuperativo" (idem, p. 48).

\footnotetext{
${ }^{86}$ Quando em certas atividades físicas cria-se débito de oxigênio produz-se lixo químico no organismo; quando não há débito e o consumo e o débito do oxigênio eqüivalem-se, não há praticamente fabricação do chamado lixo químico. Importa-nos entender que as atividades físicas que exigem intenso esforço muscular com força são essencialmente anaeróbicas. Resulta que a exaustão física, nessas condições, torna-se bem fácil de acontecer. Para que a pessoa não se esgote é necessário um treinamento especificamente orientado, que permita um acúmulo maior de glicogênio nos músculos e fígado e, com isso, cause menos desgaste. Mas esse condicionamento só é obtido com treinamento adequado.
} 
A influência do simpático é que mobiliza todos os órgãos do corpo humano para a atividade física: é ele que faz aumentar a frequiência cardíaca, que aumenta a força das contrações do coração, que intensifica o ritmo respiratório e aumenta o volume de ar inspirado. É também o simpático que, modificando o limiar de sensibilidade das terminações motoras, aumenta a reação muscular aos estímulos. A atividade cardiovascular é também intensificada por uma hormona - a adrenalina - produzida pela medula supra-renal. (Schmolinski, 1982, p. 48).

Pode-se desenvolver a força ${ }^{87}$ por meio de exercícios estáticos, suportando pesos, e/ou por meio de exercícios dinâmicos, realizando movimento.

Os movimentos executados no trabalho nesta Fábrica não se caracterizam como exercícios corporais de desenvolvimento de força, mas como atividade física que gasta muita energia por necessitar o tempo todo de força na realização das atividades. Nessas ações, ao mesmo tempo em que os trabalhadores se movimentam dinamicamente, exercitam ações motoras estáticas.

Percebemos que é possível associar a realização de um movimento tanto com vistas a adquirir força, quanto numa exercitação cujo objetivo é montar um motor. O processo orgânico é o mesmo. O componente neurológico é de grande importância nesse processo. Ora, esses elementos estão intimamente relacionados e interdependentes, só os separamos para melhor explicá-los.

Uma importante consideração é que o organismo humano possui uma grande capacidade de se adaptar a diferentes circunstâncias e isso o habilita, segundo ainda Schmolinsky (1982), a aperfeiçoar e desenvolver fatores motores que atendam ao objetivo que se tem em vista. Nessa pesquisa, estamos conhecendo os elementos que estão forjando a Ginástica na Empresa como tecnologia organizadora do trabalho, tendo em vista o funcionamento equilibrado do organismo (o corpo produtivo), para que se alcance uma alta

\footnotetext{
${ }^{87} \mathrm{~A}$ produção da força muscular depende de vários fatores, que podem, em parte, ser influenciados pelo exercício, a saber: 1 - O tipo de fibras musculares e sua percentagem nos músculos. 2 - A seção fisiológica do músculo, ou seja, o número de fibras musculares desse músculo e a capacidade de força que apresentam. $\mathrm{O}$ número de fibras musculares é inato, mas a sua força cresce. O aumento de volume das fibras musculares parece depender dos esforços a que elas são submetidas. A tensão produz força. 3 - O número de fibras musculares que participam na contração. 4 - A boa irrigação sangüínea do músculo. Este fator é particularmente determinante no caso de contrações muito fortes e duradouras. 5 - O grau de elasticidade muscular. Como os músculos são elásticos, aplica-se-lhes o mesmo princípio que à borracha: quanto maior for a sua extensão (os fusos musculares e tendinosos), o músculo se protege contra excessivas extensões. 6 - A regulação do tônus muscular do desportista pelo sistema motor extrapiramidal. Quanto mais baixo for o tônus muscular, mais fácil e mais rápida será a contração (Schmolinski, 1982, p. 50).
} 
produtividade. O equilíbrio de alguns fatores orgânicos promove, como conseqüência, melhora no processo organizacional do trabalho.

Com movimentos estáticos, consegue-se produzir força máxima, ou seja, com a máxima tensão muscular. Com essa tensão, contraímos os vasos sangüíneos e assim não permitimos o fornecimento de nutrientes e oxigênio suficientes aos músculos; os resíduos metabólicos são eliminados precariamente e o calor também não é eliminado. Para manter a contração muscular, o sistema nervoso não interrompe a transmissão dos impulsos. Assim ocorre a fadiga; o cansaço.

Vejamos, na montagem dos motores elétricos, os trabalhadores estão com toda a sua unidade corporal em ininterrupta contração, por conta da força exigida pelos movimentos. Não é à toa que a maioria dos entrevistados, como já apontamos, acusa o cansaço como consequiência direta do trabalho.

A fadiga e o cansaço podem ocorrer na realização de movimentos dinâmicos, mas se realizarmos esses exercícios sem muita repetição e em pouco tempo (os doze minutos da ginástica atendem a esse critério), isso provavelmente não acontecerá; pois esse modo de exercitação corporal comprime as fibras musculares pela extensão e pela contração; por isso, essa contração comprime o sangue que vai para as veias, a pressão é reduzida e o sangue consegue irrigar os tecidos novamente. A circulação sangüínea também é melhorada, graças a uma verdadeira massagem vascular; os nutrientes e o oxigênio chegam com menor dificuldade e ainda dão alívio ao sistema nervoso, pois os impulsos são alternados.

O problema de um músculo sempre contraído e tenso é que, além de consumir muita energia para manter-se nessa condição, produz um encurtamento no tamanho de suas fibras e com isso cria-se uma camisa de força. Os músculos encurtados, já não conseguem tanta energia, pois não se tem muito o que contrair. Com a musculatura alongada, numa solicitação de contração, o volume contraído é maior e a força produzida também. Assim sendo, o corpo produtivo carece do estímulo ao corpo que brinca, uma vez que é por esse corpo que estes fatores motores poderão estar presentes.

Na prática da Ginástica na Empresa deparamos com o corpo que brinca, fazendose presente, sem eliminar o corpo que produz. Essas conexões já mudam o parâmetro de 
análise. Este corpo já não está produzindo individualmente, pois quando os trabalhadores estão ordenados em células de produção, eles estão produzindo em equipe; entretanto não existe um contato maior entre eles, mas com a prática da ginástica há outros corpos para brincar. Muitos dos entrevistados afirmaram que, apesar de estarem no mesmo local e em muitas ocasiões ao lado do outro montando os motores, não se conheciam.

Parece que está havendo a construção, o desenvolvimento e o possível amadurecimento de uma cultura corporal dentro dessa fábrica que, para o conjunto das relações existentes em Jaraguá do Sul, pode expressar uma mudança de sociabilidade, haja vista a constatação de um traço de superação à cultura dominante, forjada aí pela história de colonização européia - alemã, principalmente.

Vimos que não há inibição das expressões de alegria dentro da Fábrica $X$, e a exaltação da seriedade, não é percebida. Ou seja, apesar da ênfase no corpo produtivo, o clima de camaradagem e alegria era habitual. Pareceu-nos que o corpo que brinca foi facilmente assimilado nesse conjunto, uma vez que também se aprendeu a expressar emotividade e como nessas relações internas esses componentes não são inibidos, parece haver certa facilidade e familiaridade nesse ambiente.

Rodrigues (1980) afirma que é preciso considerar que "sentir emoção" também se aprende. Acrescentamos que, como ali é permitido expressá-la, viabiliza-se a possibilidade, por via indireta, de maior relaxamento na dinâmica da ginástica. $\mathrm{O}$ corpo que brinca une, assim, a polaridade cansaço e prazer no desenrolar das relações experenciadas dentro do trabalho. O cansaço de produzir motores elétricos é compensado pela alegria e pelo prazer no momento da ginástica, com o contatos entre eles.

A expressão dessa polaridade como um produto social não é fácil. Marcuse ${ }^{88}$ (1981) apresenta, sustentado em estudo de Freud, dois princípios que regem essa polaridade: é o princípio da realidade (do desempenho) e o princípio do prazer, cuja conexão alternada, em síntese, pode mobilizar a nossa energia para o trabalho com menos dor.

\footnotetext{
${ }^{88}$ Esse estudo parece-nos rico o suficiente para posterior aprofundamento na relação do biológico e do social
} numa perspectiva mais centrada na psicanálise. Nesse momento apenas nos situamos na questão. 
Com a nítida solicitação do princípio do desempenho do corpo nesse trabalho e com momentos de estímulo ao prazer na ginástica, será que não se estaria assegurando, segundo Marcuse (1981), uma excelente condição de produtividade e anestesiando os sentidos para uma vida de mais prazer fora do tempo de trabalho, uma vez que nessa condição, o ser humano é tomado em sua totalidade para se dedicar praticamente ao trabalho?

A segunda coordenadora do SESI local de Jaraguá do Sul, apesar da preocupação em dar continuidade ao modelo da ginástica que estava sendo implantado pela coordenadora anterior, eliminou quase totalmente o toque corporal. Por um lado, ela atendeu a uma reivindicação de alguns trabalhadores, mas por outro, isso pode indicar que essa expressão não foi de fácil apreensão e aceitação pela maioria dos trabalhadores. Apesar de essa prática estar vinculada à influência que as relações do trabalho exercem diariamente no indivíduo, ela sofre outras determinações além desse individual, isto é, sabemos que não se constitui numa relação de causa e efeito, e que há muito mais a considerar para que tal relação se estabeleça.

Yozo (1996, p. 24) escreve: "a utilização de jogos que envolvem contato físico é de extrema sutileza [...]. A aplicação inconseqüente gera também o aumento da resistência ao jogo".

Percebemos que é possível proporcionar experiências com o corpo que brinca viabilizando, no mínimo, a estimulação, mesmo que inicial, da consciência de uma cultura do corpo para além do corpo produtivo e disciplinado, em que o corpo que produz é o mesmo que brinca, tanto na fábrica como fora dela, porém, ainda temos um caminho aparentemente longo a percorrer.

Segundo Rodrigues (1980, p. 4), o cérebro humano seleciona e processa as informações que lhe oferecem segundo as referências que lhes são introjetadas pela socialização. Essa introjeção acontece via escola, família, religião, trabalho, enfim pela cultura forjada nas instituições sociais.

Os sentidos dos fenômenos sociais só podem ser apreendidos em intelectos individuais com que o pesquisador entra em contato, pois os símbolos são apenas puras convenções abstratas que os indivíduos observam para tornar a vida social, ao nível de organização, possível. 
Se esses trabalhadores praticamente vivem trabalhando na fábrica, na cultura propiciadora da compreensão de corpo que se evidencia nela será, sem dúvida, a que permeia as relações sociais dentro da Fábrica.

A Ginástica na Empresa como tecnologia organizadora do trabalho, poderá vir a acrescentar aos trabalhadores nova compreensão e novos conhecimentos sobre o corpo, mesmo estando a cultura desses trabalhadores centrada no trabalho assalariado como condição para uma vida digna. Desta forma, o tempo deles está organizado em função do trabalho.

\subsubsection{O CORPO QUE BRINCA NO TEMPO DE TRABALHO}

O sentido atribuído à Ginástica na Empresa, por alguns dos trabalhadores entrevistados que a vincularam a práticas de lazer, confirma-nos a urgência de uma distinção entre o que é trabalho e o que é lazer. Explicando melhor, dentro da Fábrica, o tempo está organizado de forma que as atividades ali exercidas possam dar conta da fabricação dos produtos a que a empresa se propõe. Esse tempo não é para si, mas para essa produção. Ressaltamos que essa idéia não elimina a possibilidade de certos ambientes de trabalho poderem ser agradáveis ou não, alegres ou não, bonitos ou não, isso não mudará o sentido de se estar ali para produzir algo que vai ser colocado num mercado e que a pessoa, principalmente se tratando de produção industrial, está ali vendendo a sua força de trabalho. Por mais que os donos de uma empresa sejam atenciosos e preocupados com os corpos produtivos, o que vai dinamizar o processo de trabalho é a eficiência desses corpos na fabricação dos produtos.

No entanto, é deveras complexo que haja uma interrupção nessa produção para exercitar um corpo com brincadeiras. Ora, na realidade existe essa parada, os trabalhadores exercitam-se e de fato brincam, porém, o sentido definidor desse momento não seria de lazer, mesmo tendo a presença do lúdico nas atividades executadas. Se recortamos a atividade em si, ela assume as características de uma prática com conteúdos lúdicos. Porém, reafirmando o que já foi dito, para captarmos o seu real sentido, não a definiríamos isolando-a, mas inserindo-a numa rede de fios (das relações) em que ela está envolvida, parafraseando Vázquez (1977). 
A busca do equilíbrio do corpo produtivo por meio de estímulos ao corpo que brinca gera tal confusão. Em síntese, o corpo está exercitando funções ${ }^{89}$ necessárias ao melhor desempenho e produtividade no trabalho. $\mathrm{O}$ expediente de trabalho e a atividade de produção, nessa fábrica, são exaustivos, cansativos e repetitivos, como já foi dito.

Importa-nos nesse momento analisar o que acontece dentro do expediente de trabalho que determina a diferença entre essas atividades. Percebemos que a relação entre o tempo cronometrado e a produção é mais forte do que a aparência expõe. Esse tempo está sendo organizado no sentido de que o trabalhador possa produzir, realizar uma atividade dirigida para a produção de motores elétricos e não para outra finalidade.

Ao ser interrogado sobre a flexibilização da jornada de trabalho e as relações entre as tecnologias e o tempo de trabalho, o gerente da Fábrica respondeu [...] A minha jornada continuou sendo oito horas e quarenta e oito minutos e dentro dessas horas faço a minha produção e a ginástica, sem nenhum percalço (Anexo 1). Fica claro que esse tempo está sendo considerado como voltado inteiramente à atividade produtiva.

A confusão na compreensão de uma atividade que é vinculada ao trabalho e entendida por esses trabalhadores como atividade de lazer pode esconder a relação de compra e venda da força de trabalho e, com isso, camuflar a condição de assalariamento do trabalhador. Nessa fábrica, a perspectiva de a pessoa ser valorizada como um ser humano e não como uma máquina produtiva conduz a um estímulo em que ela pensa que não é apenas uma peça da grande engrenagem. Além disso, consolida a sensação de não ser substituível facilmente, pois nessa empresa é incentivada a pouca rotatividade de trabalhadores.

Perguntamos ao gerente: Empregou-se aqui, ninguém quer mais sair?, ele responde: [...] estou com 20 anos de empresa, tem pessoal aqui dentro que já tem 25, 30. Isso é normal. Cada crachá dos colaboradores tem um emblema que significa dez, quinze anos, comece a observar que você vai ver (Anexo 1).

O princípio que a empresa se empenha em cumprir fielmente, da durabilidade do emprego, propicia um vínculo afetivo que parece extrapolar a relação capital trabalho. Como

\footnotetext{
${ }^{89}$ É de fundamental importância que tenhamos claro que não estamos avaliando se é boa ou ruim a relação entre o corpo que produz e o corpo que brinca dentro do expediente do trabalho, mas constatando o que de fato se atinge.
} 
afirmou um dos entrevistados: essa empresa representa segurança, consistência, conseguir um emprego nela significa estarmos seguros [...] (Anexo 6). Mesmo assim o trabalho não deixa de ser assalariado.

Aliada às diretrizes da proposta do SESI, existe a idéia passada de que essa prática de exercitação corporal poderá contemplar a possibilidade de um lazer para fora do tempo de trabalho. Entretanto, de acordo com as respostas dos trabalhadores entrevistados e as observações realizadas em alguns finais de semana, a repercussão fora do trabalho ainda não se deu. A maioria deles respondeu que pouca coisa mudou em relação à família ou mesmo fora da fábrica, o traço mais marcante nas respostas está associado intimamente à redução do cansaço e do estresse.

Reafirmamos que essa prática está atingindo diretamente a organização do trabalho, haja vista a melhoria no desempenho das tarefas necessárias à montagem e fabricação dos motores elétricos. Para atingir o tempo fora do trabalho, esses trabalhadores necessitariam, como condição sine qua non a redução da jornada de trabalho ${ }^{90}$. A relação entre a Ginástica na Empresa e a possibilidade de ela contribuir para um estímulo à prática de um lazer como desdobramento do trabalho, não está configurada nessa realidade.

Os trabalhadores, quando afirmam que a Ginástica promove maior contato entre eles, revelam, também, que essa prática, além de estar de fato contribuindo na organização do trabalho promove, sob um ponto de vista mais humano a percepção de que existe um tipo de sociabilidade não coisificada nas relações internas de trabalho; e que nessa empresa há contato entre os trabalhadores, ou seja, a coisificação humana está longe de existir, pois os trabalhadores formam uma família ${ }^{91}$, uma vez que há também laços afetivos entre eles.

Perguntamos a um trabalhador por que ele achava que essa empresa cresceu tanto, ao que ele nos respondeu:

Talvez o ramo, tecnologia, administração, muito boa administração a da [...]. A gente vê que tem muitas empresas em que têm desperdício ou negócios errados. A [...] não, ela sempre faz a pesquisa, tu queres comprar uma coisa maior na [...], vamos supor, um valor de $R \$ 1.500,00, R \$ 2.000,00$, tem que passar por uma comissão, tem que ser julgado, tem que justificar a compra (Anexo 6).

\footnotetext{
${ }^{90}$ Analisaremos essa questão com mais detalhes no próximo capítulo.

${ }^{91}$ Uma das idéias passada na divulgação da cultura da empresa é que essa empresa é uma família.
} 
Tentamos confirmar a idéia e perguntamos: Isso é o que dá certo?, ele confirma: É, isso é o que dá certo (Anexo 6).

Assim, a dinâmica dessa prática corporal no contexto desse trabalho pode, ao mesmo tempo, revelar e esconder. Revela que não existe uma relação entre eles de associação e sim uma justaposição, junção de partes, pois eles não estão ali de forma associada para produzir motores. Porém, naqueles momentos da ginástica, o clima de proximidade e contato entre eles lhes causa uma outra impressão, a do encontro com o outro, e esconde que aquela comunhão, no momento da Ginástica é apenas passageira, momentânea.

A Ginástica na Empresa como tecnologia organizadora do trabalho, obviamente, deve acontecer no tempo de trabalho e não viabilizar o sentido de uma prática de lazer. $\mathrm{O}$ tempo cronometrado entra, então, como condição dessa distinção. Para entendermos que a separação entre as atividades de trabalho e as de lazer está permeada, principalmente, pela condição de tempo ${ }^{92}$, precisaremos ter claro que o pressuposto dessa divisão do tempo em horas se fundamenta na necessidade de organização do trabalho com vistas à produtividade. Com isso, o que resta, o que sobra, quase não permite a exercitação de atividades que possam fugir diretamente das exigências requeridas nas atividades laborais.

Esta confusão dos sentidos que os trabalhadores estão formulando sobre a Ginástica na Empresa, uma vez que para eles qualquer exercitação corporal ${ }^{93}$ é concebida como atividade de lazer, serve para consolidar o ponto de vista da empresa, ao divulgar a todo custo que a sua cultura é a de que o ser humano é central naquela organização. Pois bem, já vimos que o subsídio que dá sentido a essa atividade no meio da jornada de trabalho não seria a evidência do corpo que brinca, mas o uso desse corpo com o propósito de promover o equilíbrio funcional para o alcance da produtividade e desempenho do corpo produtivo, sob o ponto de vista do rendimento.

O sentido da Ginástica na Empresa como uma tecnologia organizadora do trabalho dá- se pelo destino e dependência em relação ao trabalho produtivo. É o trabalho que

\footnotetext{
${ }^{92} \mathrm{O}$ tempo fora do trabalho poderia estar sendo utilizado para outras atividades que não estivessem orientadas para essa produtividade necessária e exigida. No entanto, não é essa a prática que constatamos, conforme a exposição e análise do próximo capítulo.

93 Esses dados serão trabalhados no próximo capítulo. De acordo com as respostas dos trabalhadores tanto no questionário quanto nas entrevistas, existe uma idéia fortemente presente de que as atividades relacionadas às práticas corporais significam lazer.
} 
orienta e organiza esse tempo e não atividades de lazer. Nesse intervalo, nessa parada, como bem observam o gerente e o coordenador do programa do SESI, existe uma aproximação com o recreio ${ }^{94}$ escolar, mas nesse caso não é um recreio, é uma parada em que a rotina é modificada para descansar a exacerbação de solicitações de certos grupos musculares.

Na tentativa de conhecer o que os trabalhadores mais sentiam com a prática da ginástica, ouvimos que havia uma melhora na disposição para continuar trabalhando, aliviaram-se as dores nas pernas, as dores em geral e que a Ginástica também permitia conhecer o colega ao lado, pois no momento do trabalho eles não têm como se falar. Nas palavras de um entrevistado: A gente faz amizades com o pessoal, conversa um pouco, se não fica aquela rotina muito pesada do dia a dia e fora dele nos sentimos muito satisfeitos porque é sempre bom ficar exercitando o corpo, para evitar futuros problemas. Já vi bastante gente que não faz exercícios e com o passar do tempo vai acumulando problemas (Anexo 6).

E ainda, interrogamos sobre os benefícios e os malefícios que a Ginástica poderia lhes promover, as respostas foram quase unânimes, confirmando que, há, com ela, mais disposição para continuar o trabalho. Vejamos algumas respostas:

... é muito bom, ajuda bastante, sinto mais disposição para trabalhar;

... ajuda um pouco, distrai;

... traz mais disposição para o trabalho;

... melhora a disposição para o trabalho, ela quebra o ritmo e parece que você está começando de novo;

... é muito bom, a gente se sente muito bem;

... ajuda bastante, a gente trabalha com mais disposição, diminui a dor no corpo, a gente dorme bem;

... ajuda um роисо;

... com a ginástica a gente fica mais bem preparado;

... mais disposição, vontade de trabalhar;

... ela cria mais movimentos que a gente não faz no trabalho, a gente fica mais disposto (Anexo 6).

\footnotetext{
${ }^{94} \mathrm{O}$ recreio foi uma primeira forma, segundo Marinho (sem data) de relacionar a educação física com as práticas de lazer, daí a vinculação de recreação com jogos e brincadeiras.
} 
Assim, os trabalhadores, ao entenderem que têm lazer diariamente, como muitos afirmaram, por praticarem a Ginástica na Empresa, prendem-se à aparência. Na essência, essa atividade não passa, em seu sentido restrito, convém frisar, de uma recomposição orgânica, e mental, obviamente, para aquele trabalho imediato. No sentido mais amplo, a prática da Ginástica na Empresa pode absorver, não de forma nítida, um conteúdo lúdico e à primeira vista aparentar ser improdutiva para o rendimento numérico de montagem de motores. Porém é essa dubiedade que faz a confusão e possibilita que se perceba no corpo subordinado em quase todas as suas dimensões àquele trabalho exaustivo e repetitivo, um outro corpo que também está ali, porém esquecido, o corpo que também brinca, e, por viabilizar por alguns momentos a sua existência, não a autoriza a se constituir como uma atividade de lazer, ou essencialmente lúdica.

A distinção entre o tempo de trabalho e o tempo de lazer faz- se necessária. Apesar de o tempo de que esses trabalhadores dispõem estar praticamente voltado para a vida do trabalho dentro e fora dela. Dessa forma, a cronometragem do tempo em horas é uma subordinação às exigências de organização do trabalho sob o ponto de vista de referências econômicas (Cunha, 1987) e, para que se realizem atividades de lazer, esse tempo terá de não estar subordinado a essa cronometragem e não atender a uma finalidade de matriz econômica.

Essa tecnologia se concretiza por uma exercitação corporal orientada, desenvolvida diariamente pelos trabalhadores. De um lado, ela sustenta-se pela busca do equilíbrio do corpo que precisa estar adequadamente disposto para o alto nível de solicitação produtiva, e, de outro, pela exercitação e expressão do corpo que brinca. Dessa prática, resultam vários desdobramentos que, por esta conexão, atingem o processo interno de trabalho. A disposição para o trabalho é um deles.

A característica que dá o aporte de uma novíssima tecnologia se subsidia na ação centrada na busca de equilíbrio do corpo que produz dos trabalhadores, evidenciando o corpo que brinca. A partir dessa relação, atinge-se o processo interno de trabalho. Vale dizer, a evidência, aqui, do corpo que brinca é para garantir equilíbrio no corpo que produz 
Vimos também que o tempo gasto ${ }^{95}$ no envolvimento e preparação para o trabalho, aliado ao total de horas diárias no expediente habitual, não está permitindo que esses trabalhadores mantenham atividades fora do trabalho, que possam ser caracterizadas como de lazer ${ }^{96}$, mesmo que seja para se recompor organicamente.

As exigências organizadoras do processo interno de trabalho da Fábrica $\mathrm{X}$ ordenam-se de forma que predomine a eficiência com produtividade na atividade laboral desses trabalhadores. Alia-se a essas exigências a busca do baixo custo na fabricação dos referidos produtos, permitindo sua venda e sua manutenção ${ }^{97}$ no mercado nacional e internacional com preços competitivos.

As implementações tecnológicas possibilitadoras de melhorias no processo interno de trabalho dessa empresa, que garantem o almejado rendimento (produtividade), são presenças permanentes em seu modo de proceder. Nas palavras do gerente da Fábrica X: $o$ que importa é que haja produtividade e eficiência. Atendendo a esses requisitos, qualquer melhoria e novidade são bem vindas (Anexo 1), inclusive a ginástica.

Enfim, no conjunto dessa empresa, particularmente na Fábrica $\mathrm{X}$, pudemos constatar como sendo realmente uma novidade tecnológica a ginástica ${ }^{98}$, pois implementação e desenvolvimento de tecnologias em termos de maquinaria é acontecimento trivial em sua história, não se configurando como uma novidade, nem possibilitando tempo livre com lazer na vida dos trabalhadores pesquisados.

\footnotetext{
${ }^{95}$ Segundo Cunha (1987), em seu ensaio A Felicidade imaginada, a negação do trabalho e do lazer, a conexão entre a afirmação de se gastar tempo está associada a inserção do tempo a partir do viés econômico, ou seja, para esse autor, o fator tempo na sociedade atual torna-se uma categoria de análise econômica.

${ }^{96}$ Essa análise está contida no capítulo seguinte.

${ }^{97}$ Assistência técnica.

98 A Ginástica na Empresa é assunto novo nos cursos de formação para professores de educação física. Por exemplo, no curso de licenciatura em Educação Física, da Universidade Federal de Santa Catarina não existe disciplina, em sua grade curricular, que trate desse assunto.
} 


\section{O LAZER DOS TRABALHADORES E O LAZER NA CIDADE DE JARAGUÁ DO SUL}

Neste capítulo, analisamos elementos contraditórios que expressam limites e ao mesmo tempo possibilidades para existir, de fato, um tempo livre com lazer na vida dos trabalhadores do grupo pesquisado. Essa análise partiu das condições do processo de trabalho no interior da Fábrica X em relação às condições de vida dos trabalhadores fora do trabalho. A direção da análise preocupou-se com o que esses trabalhadores concebem por lazer e como realizam atividades dessa natureza fora do trabalho, tanto em relação às opções que a cidade oferece quanto ao que eles realmente exercitam, considerando as influências das relações sociais experenciadas na atividade laboral que realizam na fábrica.

Fundamentamos essas análises na compreensão do tempo linear e habitual conforme Santos (2001), Thompson (1991) e Lefebvre (1984), de lazer na perspectiva de uma atividade em que só pode ser definida em relação ao trabalho, a partir das idéias de Marinho (1984), Bosi (1978) e do trabalho, conforme Heller (1991), entendendo-o como uma atividade habitual e necessária à sobrevivência, concebemos a cultura como expressão humana, a partir da formulação de Covre (1996).

Expomos, no primeiro item, as atividades de lazer que são oferecidas na cidade de Jaraguá do Sul, tanto as promovidas pela política pública local quanto as de caráter privado, tendo como subitem suas festas. No segundo item, analisamos e apontamos as práticas de lazer adotadas pelos trabalhadores, seus gostos, preferências, dificuldades, tendo como subitem a análise do lazer como uma construção social caracterizada como uma necessidade humana. No terceiro item, analisamos o caráter social do lazer, procurando diferenciar trabalho e lazer, separando-os, mesmo eles sendo sínteses do mesmo processo de produção da existência. No quarto e último item, analisamos as variadas concepções de lazer a partir da percepção dos trabalhadores. Nele, comparamos essa variabilidade com formulações de autores que tratam do tema, destacando ${ }^{99}$ Dumazedier (1973), Marcelino (1990), Parker (1978) e Marinho (1984). A importância em analisar essas concepções junto a esses autores, constituiu-se como um recurso para aprofundar essa questão polêmica e complexa. 


\subsection{O lazer na Cidade de Jaraguá do Sul}

A cidade de Jaraguá do Sul adquiriu um significativo peso social no Estado de Santa Catarina. Para que possamos ter uma idéia da sua importância, basta lembrar que ela ocupa o terceiro lugar em produção industrial no Estado.

Nessa cidade existem diversas atrações como casas típicas, museus, construções antigas, pontes pênseis, trilhas ecológicas. O shopping center inaugurado em 1998 com três cinemas ${ }^{100}$ promove feições modernas à cidade.

Um centro cultural ${ }^{101}$ está sendo construído. Ele disporá de um teatro de 1000 lugares destinado também para encontros, convenções e palestras, mais dois auditórios com 250 lugares e 144 lugares; um piano bar, um restaurante panorâmico com 500 lugares, mais salas para cursos, reuniões executivas, empresariais e culturais. Além desses, estão previstos a construção de dois salões para exposições e uso variado, espaços para escola de música, artes cênicas e plásticas, corais, orquestras e folclores.

A construção do referido centro cultural evidencia que a cidade possui uma qualidade de vida diferenciada também em relação a alguns aspectos de espaço cultural. Existe incentivo a grupos folclóricos de origem alemã, justificada pela busca do resgate das tradições dos antepassados. Um dos grupos de dança folclórica alemã e que faz parte da SCAR (Sociedade de Cultura Artística) é o Nachstern Volkstanzgruppe, que eles traduzem para o português como Estrela da Noite. Esse grupo é convidado periodicamente para se apresentar em diversas cidades dessa micro-região. Para participar no grupo é só freqüentar os ensaios, que ocorrem aos domingos, no centro cultural.

\footnotetext{
${ }^{99}$ Comparamos com os autores acima citados tendo em vista que no Brasil, as poucas pesquisas realizadas que dispõem de dados empíricos centram a investigação no tipo de ocupação do tempo, como afirma Bosi (1977).

${ }^{100} \mathrm{O}$ cinema foi extinto há algum tempo, só voltando a existir esse espaço cultural com a implantação desse shopping center.

${ }^{101}$ Para obter os recursos de construção desse centro, há uma campanha de esclarecimento na cidade no sentido do uso da Lei Rouanet, a qual pode deduzir do imposto de renda doações em dinheiro, materiais diversos ou até em prestação de serviços, tanto de pessoa física como de pessoa jurídica. Há uma vinculação desse centro com a SCAR, uma vez que ela é reconhecida de Utilidade Pública pela lei municipal de n. ${ }^{\circ} 15$, de 29 de setembro de 1958, lei Estadual n..$^{\circ}$ 2.123, de 26 de outubro de 1959 e Decreto Federal MJ nº 16.647/90-02, de 22 de novembro de 1991. Essa sociedade existe desde 08 de junho de 1956.
} 
Existe também um grupo de teatro amador. A peça infantil Os grandes Mágicos do circo marca a estréia do Grupo de Teatro Adulto da SCAR, que atua desde $1987^{102}$. Existem oficinas de teatro juvenil e adulto com dois níveis de solicitação: um primeiro nível que abrange a iniciação teatral ou preparação do ator, nesse nível há o desenvolvimento dos seguintes elementos formativos: expressão vocal e facial, expressão corporal, consciência sensorial, maquiagem, técnicas de mímica. Já para a oficina de veteranos o objetivo é procurar avançar o processo iniciado no primeiro nível construindo os personagens e montando peças.

A Associação Jaraguaense de Artistas Plásticos (AJAP) existe desde 1990 e para participar só é necessário a apresentação de três trabalhos avaliados por uma comissão. Ela promove exposições e cursos . Há uma oficina de arte onde além de utilizarem-se dela, em certos momentos como um ateliê, também promove cursos como cerâmica, escultura, pintura, história da arte e técnicas decorativas.

Na cidade existe uma escola de música, desde 1976. Essa escola promove cursos, palestras e o incentivo para a formação profissional em música, promovem concertos e audições pelos alunos no final de cada semestre. Há cursos de música popular, canto, canto coral - coral, bateria, contrabaixo elétrico, flauta doce, guitarra, oboé, piano clássico e popular, viola, violão clássico e popular, violão método Suzuki, violino tradicional e violoncelo; na teoria musical, dispõe de musicalização infantil, teoria, solfejo e ritmo.

Jaraguá do Sul possui uma Camerata que desde a sua fundação, em 1987, teve como maestro Ricardo Feldens, ligada também a SCAR. É uma orquestra formada por 32 componentes, gravaram um CD e excursionaram na Alemanha em 1999, nas cidades de Steinenstadt, Solingen, Mönchengladbach, Hannover e Berlim. A primeira viagem ao exterior foi para Assunção, capital do Paraguai, em 1994 e pela segunda vez em 1999. Em Santa Catarina a Camerata percorreu 10 cidades do Estado, participando do $1^{\circ}$ ciclo catarinense de

\footnotetext{
${ }^{102}$ Com a peça "Quem casa quer CASA" de Martins Pena, este grupo excursionou tanto pelos bairros de Jaraguá como nas cidades vizinhas. Mas foi com "Salão Buhr" - 50 anos após, que o grupo teve um público de mais 1.000 pessoas em 1989, era uma comédia regional. Em 1990 continua na linha de comédia com a peça a "Pensão Central", foi assistida por mais 1.500 pessoas. Já em 1991 o grupo utilizou um texto de Bráulio Pedroso "O Deus nos Acuda". Em 1992 conseguiram uma adaptação do livro de Fernando Sabino, "Martin Seco". Em 1994 foi a vez de "A Pírula", cuja temática central era o controle da natalidade, a comédia ainda é o forte desse grupo. Com o texto de Gilmar A. Moretti "Zyp-9 no Tempo do Rádio", eles apresentaram a peça de 1995. "O Noviço" de Martins Pena é encenada em 1996. "Pluft - O Fantasminha", uma peça infantil foi apresentada em 1997. Em 1999 a peça em cartaz, uma comédia, foi "Fulaninha e Dona Coisa" de Noemi Marinho.
} 
concertos. Eles se apresentaram também no Paraná e no Rio Grande do Sul. Todo final de ano esta orquestra apresenta, para a sociedade Jaraguaense, os concertos de Natal.

Para chegar à Camerata deve-se passar pela Orquestra de Câmara. Ela iniciou as suas atividades também em 1987, reunindo os alunos da escola de música. Foi a partir da Orquestra de Cordas da SCAR que se desmembraram alguns músicos para formar a Camerata da SCAR. O número de participantes da SCAR, nas suas três orquestras, perfazem um total de 50 músicos. Nas outras, não há limites de participantes.

Jaraguá do Sul possui um Centro de Ensino Superior com os seguintes cursos universitários: Administração, Arquitetura e Urbanismo, Tecnologia em mecânica modalidade de processos industriais, Letras com habilitação em português e inglês, Bacharelado em Secretariado Executivo (português e inglês), Ciências contábeis, Matemática, Letras com licenciatura em alemão (magister), Pedagogia com habilitação em educação préescolar, magistério de $1^{\mathrm{a}}$ a $4^{\mathrm{a}}$ séries do ensino fundamental e curso de Direito. Há também cursos de pós-graduação e várias escolas para aprendizagem de línguas estrangeiras.

Além dos cursos superiores, existem escolas de educação infantil, escolas de ensino fundamental e médio e escolas técnicas. A rede estadual tem um total de 18 escolas; a rede municipal tem 57, incluindo aí os centros de educação infantil; e a rede particular é formada por 9 escolas e 3 escolas técnicas.

A taxa da alfabetização, como vemos na tabela abaixo, é de quase 100\%, com dados superiores em relação ao Estado de Santa Catarina e ao Brasil. Em 2002, segundo informações da prefeitura, 31.000 pessoas, entre crianças, jovens e adultos freqüentam escolas: "É nosso orgulho poder dizer que mais de $98 \%$ da população infantil está na escola" (PMJS,2000).

TABELA 21 - Taxa de alfabetização (\%)

\begin{tabular}{c|c|c}
\hline Brasil & Santa Catarina & Jaraguá do Sul \\
\hline 85,3 & 92,7 & 98,7 \\
\hline
\end{tabular}

Fonte: PMJS,2000 
Há 9 agências bancárias; 5 postos de correios; 400 telefones públicos; 4 torres de celular. O gás natural como fonte de energia menos poluente está sendo instalado nas empresas (Jaraguá em dados, 1998). Na área de comunicação a cidade conta com três provedores de internet e cerca de 2.500 assinantes. Existem duas revistas mensais, uma empresa de TV a cabo, com cerca de 3.000 assinantes e todos os sistemas de TV por assinatura via satélite. A cidade tem, ainda, uma sucursal de TV, um canal de TV local, três estações de rádio (1 FM e 2 AM), sucursais de quatro jornais periódicos, sendo três diários e um semanal, e quatro jornais semanais.

Assim a qualidade ${ }^{103}$ de vida de Jaraguá do Sul, divulgada por todos proporciona à população amplo acesso a bens materiais e à prestação de serviços. Nela, as condições necessárias para se ter uma cidade ${ }^{104}$ funcionando de forma equilibrada e harmônica estão garantidas, de acordo com os dados da Prefeitura Municipal. Além disso, desde o final do século passado os poderes públicos e privados vêm tomando medidas para dar conta da existência de práticas de lazer, segundo o gerente de cultura ${ }^{105}$ da cidade (Anexo 5).

Contudo, essas práticas de lazer ainda não possuem tradição, de acordo com o gerente de cultura da Secretaria de Educação do município, existem vários desafios para a sua efetivação na cidade. Os principais, segundo ele, constituem-se na falta de espaços adequados e na falta de hábito, dessas pessoas, de realizar essas práticas. Perguntamos como ele equaciona esse problema, uma vez que nas visitas realizadas nos finais de semana à cidade não vimos movimento algum de trabalhadores que pudesse ser caracterizado como prática de lazer. Ele esclarece:

É verdade. Sem um planejamento, você pode passar no final de semana na praça e você vai ver uma ou duas mães brincando com o filho no parque. Para ter um evento, tem que ter uma divulgação muito grande em cima dele e você têm que se preocupar em fazer o evento e levar o público. Muitas vezes a gente faz evento $e$ temos que disponibilizar ônibus, por exemplo, para trazê-lo. Nós já fizemos isso, também é questão nossa, é dever da prefeitura se preocupar com o transporte das pessoas, não com pessoas que não têm condições de pagar o dinheiro da passagem,

\footnotetext{
103 A concepção de qualidade de vida dominante é a que está subsidiada em indicadores estritamente econômicos; a nosso ver, corresponde ao modelo de vida adequado ao ajustamento a esta sociedade, ou seja, o estímulo à propriedade das coisas, porém com essa apropriação limitada aos bens como casa, carro, eletrodomésticos e não aos bens e produtos sociais construídos no conjunto das relações por toda a humanidade por exemplo: o acesso, participação e usufruto do patrimônio cultural da humanidade.

104 No primeiro capítulo, expomos outros detalhes do que essa cidade dispõe.

105 O gerente de cultura faz parte da Secretaria de Educação do município e é responsável pela gestão das políticas públicas de lazer da cidade, segundo informação dada por ele.
} 
mas de você conseguir levar público. Então, por exemplo, se você faz uma promoção num bairro, você tem que levar os bairros vizinhos para lá.

As políticas públicas de lazer orientam-se para a promoção de espetáculos, porém, segundo o gerente, há uma preocupação em relação à formação de hábitos de lazer. Perguntamos o que orientava a política pública de lazer e quais os elementos de caráter educativo que estariam orientando essas atividades, ele declarou:

\begin{abstract}
O caráter educativo, eu acho que ele está mais voltado para as crianças e jovens, digamos assim, e com o trabalho que é realizado com a terceira idade, no Centro de Terceira Idade. Com o público adulto, eu poderia até confessar que é voltado para o lazer de consumo, proporcionar esse hábito de lazer. Mas eu acho que hoje a maior preocupação do poder público está com as crianças e jovens para que eles adquiram uma cultura. Hoje, o grande desafio realmente é voltar para a educação, e a educação como um todo. Você educar essa criança ou esse jovem para que ela tenha consciência de que precisa ter o seu lazer, mas ele também precisa ter conhecimento para adquirir um trabalho no mundo capitalista. A lógica dele qual é?
\end{abstract}

A cidade de Jaraguá do Sul está caracterizada no Estado de Santa Catarina como uma das cidades de colonização européia que, até hoje, preza enfaticamente pela garantia e preservação de certas tradições, particularmente com a alemã. É reconhecida, segundo Lopes (1998), como a capital do trabalho, o que explica e justifica uma relação com as atividades de lazer ainda frágil e premente. O lazer parece ser relegado a segundo plano pela população local, chama atenção o autor.

Essa cultura voltada, sobretudo, para o trabalho na indústria deve-se segundo Lopes (p.35) a

[...] ser uma cidade de colonização tipicamente européia. Tem no trabalho a sua maior preocupação, pois foi o trabalho de seus colonizadores no passado e é o trabalho de sua população no presente que fez e faz com que a cidade seja forte industrialmente, gerando bons empregos para a sua população.

A esse progresso econômico alia-se a concepção de que : "tudo aqui é organizado, planejado e bem sucedido e as pessoas dessa cidade são competentes em tudo que realizam" (Anexo 5). Essa é a idéia presente na fala de seus dirigentes e pessoas da cidade em geral. Ainda, segundo o gerente de cultura: se estudar e for qualificado, terá emprego. 


\subsubsection{As Festas na Cidade}

No mês de outubro, Jaraguá do Sul promove, desde 1989, a Schützenfest. É uma festa de origem alemã e em português seu nome significa festa do tiro. Essa festa é uma das heranças dos imigrantes, tais como danças folclóricas, culinária típica, os passeios em parques e a tradição das famílias se reunirem em casa (Lopes, 1998).

A Schützenfest agrega essas influências num só momento. Destaca-se a presença da culinária típica na festa, a competição de tiro, desfile das sociedades ${ }^{106}$, apresentação de grupos folclóricos de tradição alemã e a presença de bandas vindas diretamente da Alemanha para a festa. Isso tudo regado a chope. São dez dias de festa, e nesses dias, pode-se até ir para o trabalho de ressaca (palavras de um trabalhador), pois o chefe não incomoda (Anexo,6).

A Schützenfest faz parte do circuito de festas de outubro do Estado de Santa Catarina, associadas à Oktoberfest de Blumenau, à Fenarreco de Brusque, à Fenachope de Joinville, entre outras. Ela é realizada no Parque Municipal de Eventos da cidade, o qual possui três pavilhões, estande de tiro, praça de alimentação e palco para apresentações de dança. Existem também camarotes. Na figura próxima expomos uma visão dessa festa.

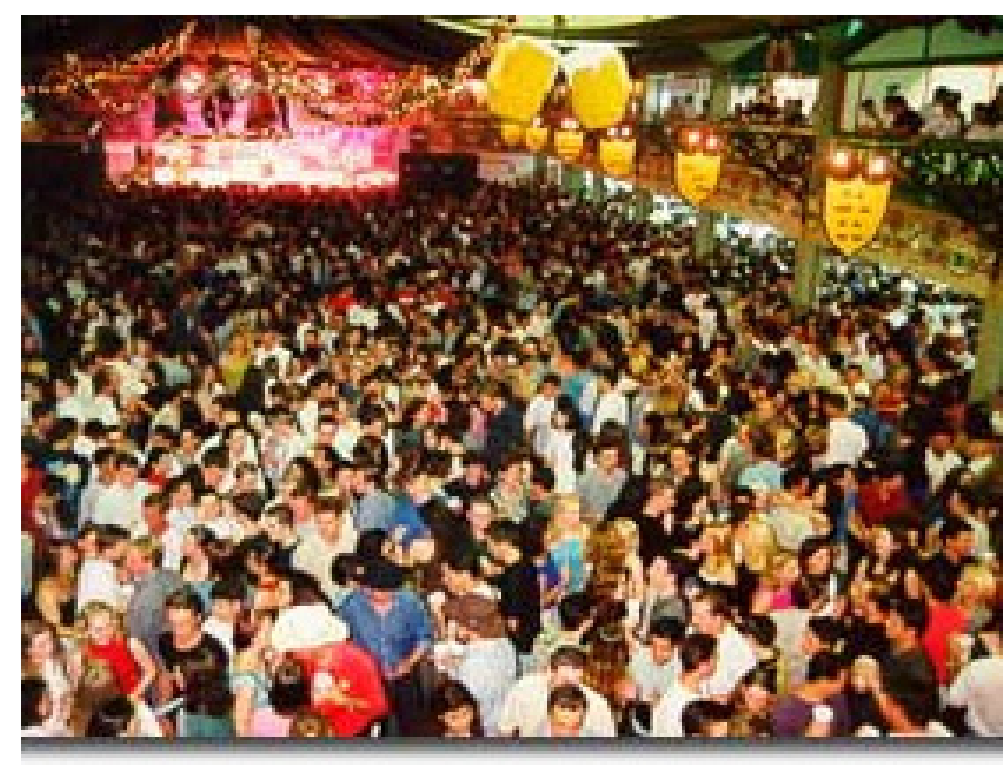

FIGURA 10 - Schützenfest

\footnotetext{
${ }^{106}$ As sociedades é um tipo de clube em que eles organizam vários grupos e denominam de sociedades de caça e tiro da região.
} 
Nenhum trabalhador do grupo pesquisado citou essa festa como uma atividade de lazer. Mas ela foi referida quando relacionada ao carnaval, afirmando que no carnaval se trabalha, mas nessa festa, não (Anexo 1).

Outra, é a Festa de Rei do Tiro, que ocorre durante todo o ano. É um tipo de preparação que tem como ponto de culminância a Schützenfest. Segundo Lopes (1998), cada sociedade escolhe um representante, que é selecionado através de uma competição de tiro: o melhor atirador torna-se rei, os outros são chamados de cavalheiros.

Os grupos que fazem parte de cada sociedade vestem trajes típicos e com um porta-bandeira saem em busca do rei em sua casa. São acompanhados por uma banda e ao saudarem o rei, ele os convida para uma competição de tiro que acontece num estande improvisado. Não falta chope, comida típica e cachaça (Lopes, 1998). Após esse encontro, eles voltam em marcha à sede social.

Essas festas do tiro, segundo Lopes (1998), realizam-se várias vezes durante o ano. Essas associações também desfilam na ocasião da Schützenfest. Na próxima página mostramos fotos de um desses desfiles.

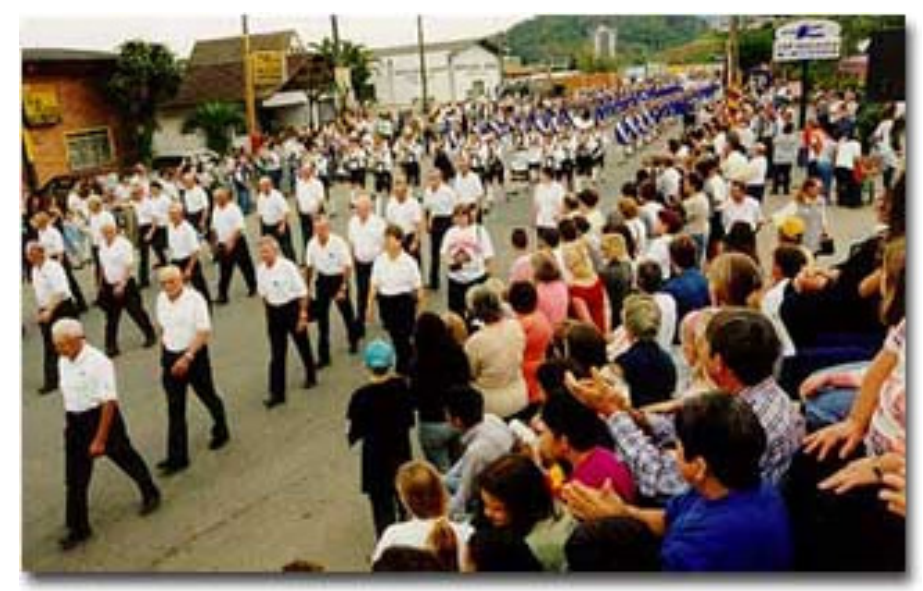

FIGURA 11 - Desfile das Sociedades 1 


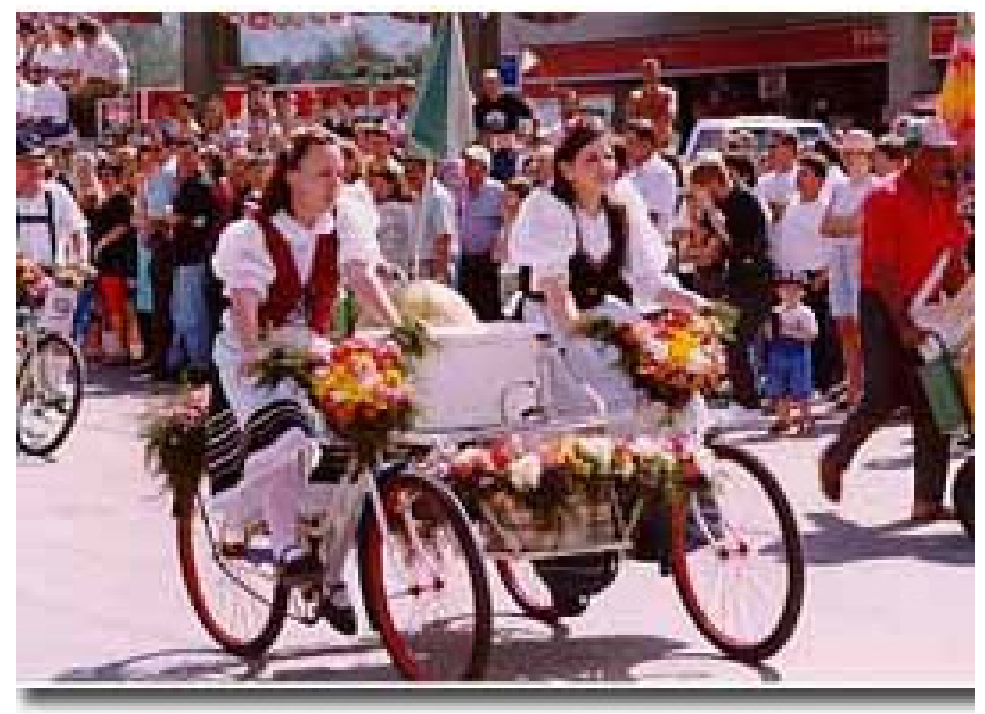

FIGURA 12- Desfile das Sociedades 2

São vários os tipos de eventos que acontecem nessa cidade, que vão das festas típicas alemãs a shows de cantores nacionais, populares, apresentação de peças de teatro, apresentação de bandas, concertos e outros, de acordo com o calendário que a prefeitura monta para ser executado durante o ano (Anexo 8).

A SCAR também promove, além de eventos variados esporádicos, cursos diversos abertos ao público. Esses cursos são pagos e oferecem praticamente todo o tipo de expressão artística: da música clássica à formação de grupos folclóricos, das artes plásticas ao teatro.

Na figura abaixo vemos um dos grupos locais:

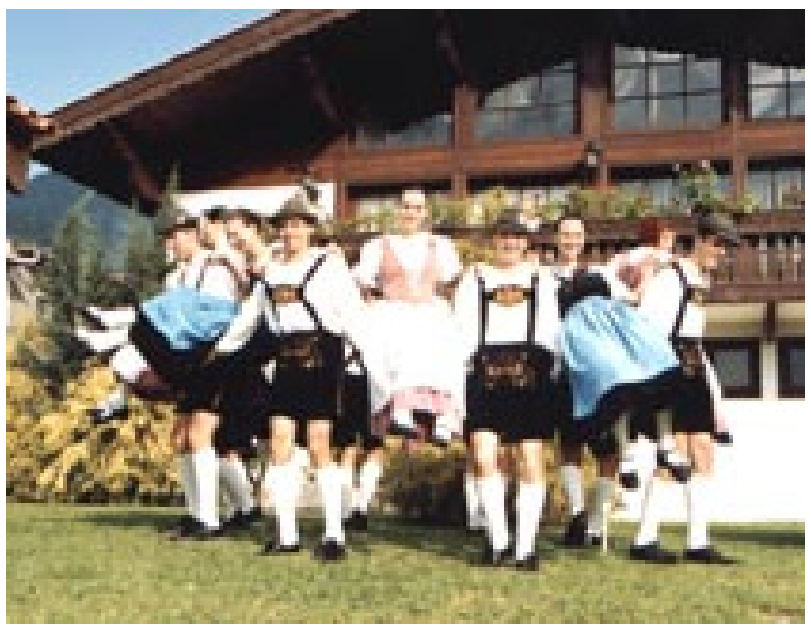

FIGURA 13 - Grupo folclórico 
Os shows acontecem regularmente na cidade, um por mês. No entanto, não podem ultrapassar o horário das $22 \mathrm{~h}$, pois as pessoas reclamam (palavras do gerente de cultura da cidade.( Anexo 5).

Saindo do âmbito das promoções e procurando explicações para a falta de participação da maioria dos trabalhadores do grupo pesquisado nesses eventos verificamos que, além da questão da falta de tempo, como foi evidenciado nas respostas dos entrevistados, aliada à falta de espaços públicos de lazer na cidade, segundo o gerente de cultura, há a falta do hábito de exercitação o lazer.

As pessoas da cidade de Jaraguá do Sul não dispõem de um lugar central, aberto e que poderia uni-las de forma espontânea, mais livre e sem ter de pagar ingresso. Essa falta de espaço público amplo é herança do tempo da colonização. Outro detalhe é a falta de esquinas na cidade, pois todo o seu traçado é em vias de acesso, estradas. A falta de espaços dificulta a reunião das pessoas, segundo a compreensão de alguns trabalhadores entrevistados.

\subsection{O LAZER DOS TRABALHADORES PESQUISADOS}

As atividades de lazer dos trabalhadores pesquisados foram classificadas em 22 categorias. Sintetizamos as elaborações desses trabalhadores às diversas perguntas: o que é lazer para você, o que você mais gosta de realizar como atividade de lazer, qual a atividade que mais lhe dá satisfação, o que você realiza como atividade de lazer e o que você faz diariamente como atividade de lazer.

Encontramos duas tendências que aglutinam as respostas das 22 categorias classificadas. Uma primeira tendência centra as respostas diretamente nas atividades que se tem e a outra tendência está centrada em explicações mais conceituais. Ambas, porém, especificam e apresentam elaborações deixando claro qual a finalidade que procuram atingir, ou o que essa atividade pode significar para eles. 
As categorias ${ }^{107}$ principais foram as relacionadas às atividades físicas e práticas de esportes, as relacionadas aos encontros familiares ou com amigos e as relacionadas às atividades que são dirigidas ao consumo, tais como ir à bares, festas, viagens, compras.

As atividades relacionadas à exercitação física e as práticas de esportes são as que eles realizam com maior freqüência. Percebemos que essas práticas têm maior aceitação das empresas, ou seja, são consentidas, incentivadas. Essa relação direta entre atividade física e prática esportiva, como uma atividade de lazer, chamou-nos a atenção desde o início desta pesquisa. Questão que foi esclarecida com a entrevista do gerente de cultura do município (Anexo 5).

Chamou-nos também a atenção o que Lopes (1998, p.36) afirma: "a forma que as pessoas dessa cidade têm para exercitarem lazer num tempo livre é rotineira e sem muita variedade, pois elas trabalham bastante, isto é, vivem para o trabalho". Esse autor explica que, como a jornada de trabalho é bem extensa, praticamente os trabalhadores não dispõem de tempo livre do trabalho, mas, se dispõem, aproveitam para descansar. Os dados levantados com os trabalhadores do grupo pesquisado revelam que eles, por trabalharem bastante, sentem-se sempre muito cansados, mas apresentaram opções de lazer diversificadas e alternativas criativas para atividades dessa natureza.

No grupo pesquisado os problemas que estão limitando a prática de atividades de lazer, segundo respostas e observações realizadas no locus da pesquisa, são a falta de tempo livre do trabalho, a falta de dinheiro para esse fim e o cansaço, resultante da atividade laboral extenuante que realizam. Dessa forma os fatores limitadores originam-se do processo de

\footnotetext{
${ }^{107}$ Categorias- Atividades relacionadas a atividade fisica/práticas de esportes- são as atividades que eles fazem com maior freqüência, praticamente todas as empresas da cidade possuem as recreativas, um tipo de clube; Atividades que promovem alegria, prazer, e de que gostem e lhes agradem - foi um tipo de resposta em que o sentido impetrado era os das reações afetivas; Atividades sociais que promovem encontros com a família e com amigos - são as que promovem os encontros dominicais ou a reunião com os amigos depois dos jogos de futebol.; Atividades que distraem- essas estão englobadas as atividades mais de consumo, como ir a bares, restaurantes, passear, fazer compras, viajar; Atividades que saem da rotina do trabalho- essa categoria deixa claro a relação de oposição ao trabalho. Atividades lúdicas, apesar de pouco citadas existe pessoas que declararam gostar de brincar com os filhos, com a família; Atividades de reposição de energia- estas são as atividades declaradamente de reposição de energia física, como relaxamento; Atividades fora do tempo de trabalho, essa também posiciona-se em relação ao trabalho, mas relacionando explicitamente ao tempo, poucos percebem essa relação; Atividades sem obrigação. Não fazem nada/não sabem; Atividades domésticas- ficar em casa, fazer coisas de casa;. Atividades religiosas- ir à igreja; Trabalhar - um trabalhador falou que era esse o lazer dele (na empresa); Ter dinheiro ( viajar);Tempo e dinheiro; Atividades que possam aproveitar tudo; Estar
} 
organização do trabalho no conjunto das relações sociais e não por limites pessoais. O lazer sendo uma necessidade subjetiva, está difícil a sua exercitação, não por falta de vontade ou necessidade da pessoa, mas pelas condições existentes, que não permitem essa realização.

A tabela abaixo apresenta em linhas gerais as dificuldades para que eles realizem atividades de lazer:

TABELA 22 - Dificuldade para a realização de atividades de lazer

\begin{tabular}{l|c}
\hline Qual a dificuldades para você ter e realizar lazer? & Porcentagem \\
\hline Falta de tempo & 34,85 \\
\hline Falta de tempo e mais outras dificuldades & 14,51 \\
\hline Falta de dinheiro .. & 10,27 \\
\hline Falta de local apropriado & 4,34 \\
\hline Falta de disposição, ânimo, incentivo ... & 6,04 \\
\hline Falta de um horário de trabalho mais adequado & 1,8 \\
\hline Não falta nada & 5,19 \\
\hline Quando ocorre imprevisto & 0,95 \\
\hline Não responderam - & 22,05 \\
\hline Total & 100,00 \\
\hline
\end{tabular}

Por essa tabela, vemos que a falta de tempo associada à falta de dinheiro, de espaços adequados, de disposição e de estímulo, limita a existência concreta de um tempo livre do trabalho para estes trabalhadores praticarem atividades lazer. Assim, para existir lazer, eles terão de conquistar, como condição sine qua non, um tempo livre do trabalho, mas que não signifique desemprego.

Em todas as empresas da cidade existe uma associação recreativa e, na opinião das pessoas, há uma vinculação direta entre o lazer e a prática de esportes ${ }^{108}$. Essa prática está atrelada ao conceito de saúde e não a uma expressão da cultura corporal. Vale a pena transcrever uma parte do diálogo com o gerente citado:

de bem consigo, tudo bem, com saúde, em paz; Quando os projetos dão certo; Mexer no computador; Ginástica na empresa.

${ }^{108}$ Costa (1990) no livro Esporte e Lazer na Empresa, analisa a relação entre a prática de esportes atrelada à visão de lazer para os trabalhadores a partir dos interesses do patronato. 
É a primeira prefeitura que tem gerente de lazer, ou sempre houve? ... Hoje, nós temos outro departamento que cuida da parte do lazer, que é a parte do esporte, daí são eventos de lazer. No departamento, eles têm o superintendente de lazer dentro da secretaria de esportes [...] Eles tem a chamada área de lazer aqui em Jaraguá do Sul, que são áreas alternativas de esporte, como campo de areia e áreas de práticas recreativas e eles desenvolvem competições esportivas, na parte de lazer, e também desenvolvem passeio ciclístico, festivais, eventos de lazer. Então, por exemplo, nessa concepção de lazer e daí então na parte da cultura entra também com esses eventos para fazer um complemento. Então, essa é a política de lazer que existe em Jaraguá do sul, hoje.

O lazer como prática de esporte e cultura é prática do quê? ... A gente faz festivais de música com a participação de estudantes, com participantes de Jaraguá do Sul, a gente faz concurso de poesias.

Você teria uma justificativa disso? Como isso se deu? Percebemos que há uma ligação forte entre lazer e a prática de esportes. Você tem alguma explicação? ... Eu não sei se tem uma explicação lógica ou não, mas, por exemplo, eu poderia colocar até a questão de falta de outras opções, ou pelo esporte estar mais presente na sua escola, nas empresas onde os pais estão trabalhando. Porque se nós formos ver o número de centros recreativos nas empresas, eu não sei se no Estado tem um número tão grande.

Toda empresa tem o seu centro recreativo? ... Toda a empresa tem o seu centro recreativo.

Isso favorece a prática de esporte? ... A prática de esporte e também outras atividades sociais.

Percebemos também que, além da vinculação da prática de esportes com atividades de lazer, existe uma relação entre elas e a concepção de recreação como atividades em que se caracterizam pela busca de alegria e prazer, realizadas por livre vontade.

As respostas vinculadas à busca de atividades promotoras de alegria, prazer, e realizadas porque as pessoas gostam delas, denotam a busca de respostas de estímulos e reações afetivas. Marinho (1984) contesta a relação entre o lazer e essa busca, afirmando que não existe o prazer, nem uma entidade com esse poder. Por outro lado, esse fascínio estendese ao lazer como atividade de consumo quando o associamos, principalmente pela propaganda (Haug, 1997), à possibilidade de se comprar felicidade. Dessa forma, o prazer é tratado como um produto disponível no mercado. A busca por esse tipo de atividade como lazer foi encontrada entre as respostas dos trabalhadores entrevistados, quando questionados sobre o que é lazer: 
... Tudo o que eu posso fazer com prazer, tudo o que eu gosto de fazer, saber dividir meu tempo entre atividade;

... Se desligar das atividades rotineiras, fazer algumas coisas que te dão prazer;

... Tudo o que satisfaz a vontade da pessoa, sente alegre, se satisfazendo;

... Ter tempo para praticar alguma coisa que a gente gosta; Me sentir bem, poder estar com pessoas alegres que transmitam alegria;

... Fazer alguma coisa que você gosta por prazer, não importa uma atividade física, cultural, mas que você realmente faz por prazer.

Segundo Lopes (1998), existe um hábito de lazer, tradição da família alemã, nesta cidade, que é o de se reunir em casa. Os trabalhadores confirmaram essa informação. As atividades sociais promotoras de encontros com a família e com amigos são as mais exercidas por eles, reúnem-se nos encontros dominicais ou após os jogos de futebol com os amigos. Algumas respostas enfocam essa postura:

... Estar bem com a família, não só jogar futebol, mas estar com a família;

... Estar com os amigos, conversar, se sentir à vontade; Além de praticar esporte fazer algo que eu gosto, estar com a família é uma das coisas;

... Sair com os colegas, se divertir bastante, ter uma saúde boa, bastante energia, desfrutar da vida, em casa, com os irmãos, família, namorada se tiver.

As atividades que distraem estão englobadas nas atividades de lazer explicitamente de consumo, como ir a bares, restaurantes, fazer compras, viajar. Nas palavras dos entrevistados:

... O cara poder tirar férias, ter um dinheiro para poder sair, viajar; ...Passear, se divertir, mudar a rotina;

... É se divertir;

... Ser alegre, se divertir, sair com a família, passear, ver amigos.

Observamos, nessa classificação que, os passeios foram as atividades mais citadas. Um único respondente citou que ia ao shopping da cidade, por exemplo. 
Apesar do corpo que brinca não estar sendo exercido nos espaços públicos, algumas pessoas declararam o gosto por brincar com os filhos, com a família privadamente, por exemplo:

... Compartilhar, brincar, passear, distrair. É se divertir, brincar bastante;

... Brincar com meu filho.

As atividades que proporcionam reposição de energia também foram citadas. São as declaradamente relacionadas à atividade física, tais como o relaxamento e a descontração. As atividades que saem da rotina do trabalho foram expressas na relação de oposição ao trabalho:

... Qualquer atividade que me traz alívio das pressões do dia- a- dia, faz sair da rotina;

... É tirar o dia, esquecer de tudo, dos problemas, do trabalho;

... A hora que não está no serviço. Estar fazendo algo diferente. Não estar no serviço;

... Quando esquece do trabalho e você tendo dinheiro, você está fazendo algo de bom para você;

... Se divertir, ficar feliz, sem pensar em trabalho;

... Não estando trabalhando, não estando doente, o resto é lazer;

... Estar descontraído, sair, se divertir mesmo, deixar o trabalho de lado, se divertir.

O caráter de desobrigação está nas respostas que dizem: "não faço nada", temos ainda os que disseram: não sabem o que é, nem o que fazem como lazer.

Em relação às atividades domésticas e o ficar em casa, alguns dos respondentes consideraram-nas atividades de lazer. Ir à igreja, para um deles era lazer. Até trabalhar na empresa foi considerado uma atividade de lazer.

Ter tempo e dinheiro relacionado à possibilidade de viajar foi também considerado uma atividade de lazer. Eles declararam ainda que, assim como a possibilidade de aproveitar tudo, de estar de bem consigo, de estar tudo bem, com saúde e em paz, também vinculam lazer à realização de projetos pessoais. A maioria dessas explicações recaem numa 
busca subjetiva de um estado de bem-estar interior, não importando o tipo de atividade, pois até mexer no computador foi citado por um trabalhador como atividade preferida de lazer. A ginástica na empresa também foi citada.

A prática de esportes ${ }^{109}$ ganha uma significação muito importante para os trabalhadores entrevistados nessa pesquisa, supomos que isso se justifica por ser uma prática estimulada pelos empresários locais, além de praticamente todas as empresas da cidade disporem de uma associação recreativa. Eles fomentam a formação de equipes esportivas e promovem campeonatos durante todo o ano, tendo o SESI o maior promotor desses eventos. Portanto, essa prática fica circunscrita aos espaços dessas associações, porém vimos que esses jogos quando acontecem, obedecem a uma programação, a um planejamento em que, por exemplo, os trabalhadores do grupo da Fábrica $X$, não estavam presentes quando estivemos observando e que não são todos os trabalhadores que participam dessas competições, mas apenas pequenos grupos. Por outro lado, considerando as informações coletadas vimos que a maior dificuldade para a participação, segundo respostas de praticamente $50 \%$ dos trabalhadores, deve-se a falta de tempo e dinheiro.

A maioria dos primeiros ${ }^{110}$ trabalhadores da indústria nessa cidade foram os operários-colonos (Schörner, 2000). Hoje, já existe uma geração mais urbana dentro da fábrica, porém, alguns dos entrevistados afirmaram que a atividade de lazer que eles realizavam era cuidar de uma rocinha que possuíam em casa:

... Cuido das minhas criações, tenho minha hortinha, tenho uma rocinha; ... Trabalho na roça;

... Tenho minhas criações para cuidar, verdurinhas, coisas que gosto de fazer.

Detectamos assim a presença de uma herança histórica, do tempo em que a produção da existência determinante na economia da cidade era agrícola.

\footnotetext{
109 Essa conexão do esporte com o lazer foi explicado pelo Gerente de cultura: (... ) hoje o nosso organograma da Prefeitura compõe a Secretaria de Saúde, Esporte e Lazer e a Secretaria de Educação e Cultura. No anterior era Cultura, Esporte e Lazer. E o prefeito quando foi indagado do porquê colocar a Saúde, Esporte e Lazer juntos: ele explica com o argumento que o esporte é um lazer relacionados à saúde. Ele defende que a saúde completa você desenvolve e com a prática do esporte como lazer você estará preocupado com a saúde preventiva. A doença você aplica o remédio, mas aqui se está preocupado é com a prevenção, o esporte entra como prevenção de doenças (Anexo 5).

${ }^{110}$ Chamamos atenção para esse detalhe por entendermos que lazer é uma construção do conjunto das relações sociais da sociedade urbana industrial, a forma agrícola de produção promove outras influências.
} 
Para Schörner (p.176)

7além das recreativas, onde se vai principalmente nos finais de semana, a maioria dos trabalhadores se encontra mesmo é nos bares depois do trabalho, onde jogam sinuca e bebem cerveja e cachaça, nas quais buscam muito mais o desabafo e o alívio da tensão do trabalho do que propriamente o seu gosto.

Percebemos que existe aprovação para se ir para o futebol e depois beber cerveja com os amigos. É hábito corriqueiro de alguns trabalhadores, de um pequeno grupo, é verdade, uma vez que isso impõe disponibilidade financeira e alguns deles apontaram como uma das dificuldades para realizar atividades de lazer, a falta de dinheiro.

Os jogos que acontecem na cidade obedecem, segundo Parker (1978), às mesmas orientações e regras do trabalho: o tempo é cronometrado, as pessoas estão uniformizadas, há regras de conduta que não podem ser infligidas e o jogo tem de estar num calendário, numa programação. Geralmente, os espaços são privados, de alguma associação recreativa de alguma empresa, ou de empresários do esporte (são quadras e outros espaços que são alugados), ou do SESI local. Segundo Schörner (2000, p. 175)

[...] o que aproxima muito esses trabalhadores são os times de futebol, principalmente os metalúrgicos - em quase todas as seções das fábricas existem times de futebol que se enfrentam aos sábados e domingos, nos campos das empresas ou em torneios que acontecem pela cidade.

Nas palavras de um trabalhador entrevistado por Schörner (p.176):

\begin{abstract}
Não existe lugar e nem tempo para a diversão, para o lazer [...] Na realidade poucos se preocupam com isso, procurando mais descansar para voltar ao trabalho. A maioria dos trabalhadores, quando não estão fazendo hora-extra, utiliza o tempo livre para dormir, ir aos bares beber ou visitar um parente próximo. Outros vão para as recreativas das empresas onde trabalham, contudo, o número dos que fazem isso é muito pequeno se comparado com o universo dos trabalhadores.
\end{abstract}

Apesar de, eles, elegerem as atividades esportivas como as principais práticas de lazer, não vimos durante dois anos de visitas a essa cidade, nos sábados e domingos, elas acontecerem, principalmente em espaços fora da fábrica, como quadras, campos, parques e na associação recreativa da empresa pesquisada. Essa falta de participação dos trabalhadores em atividades fora do trabalho é um traço que está presente de maneira significativa nos eventos 
da cidade. A dificuldade para encontrá-los em jogos de futebol, fora do ambiente de trabalho, é confirmada na fala do trabalhador acima entrevistado por Schörner, pois eles praticamente não saem de casa.

Entretanto, mesmo sem muita participação, a prática de esportes ou atividades físicas foram eleitas pelos trabalhadores como exercitação de lazer que eles gostam mais de realizar, como mostra a tabela próxima:

TABELA 23 - Preferências de lazer

\begin{tabular}{l|c}
\hline O que você gosta de fazer como atividades de lazer? & N. $^{\mathbf{0}}$ de respostas \\
\hline Atividades físicas/ esportes & 68 \\
\hline Atividades variadas, que distraem & 24 \\
\hline Atividades que proporcionam prazer ... & 01 \\
\hline Não fazem nada & 01 \\
\hline Atividades sociais, convívio social/família/amigos & 14 \\
\hline Atividades Domésticas/ficar em casa & 07 \\
\hline Ir à igreja & 01 \\
\hline Atividades lúdicas & 03 \\
\hline Trabalhar & 01 \\
\hline Total & 120 \\
\hline
\end{tabular}

Numa observação ${ }^{111}$ em que poderíamos captar traços característicos de uma atividade de lazer presentes, no jogo em si, esses traços somente apareceram após a partida, quando as pessoas se reuniram ${ }^{112}$ para conversar e beber cerveja. O jogo com as 'conservas de culturas $^{\prime 113 " ~(Y o z o, ~} 1996$ ) poderia propiciar contato com o lúdico, porém, não foi essa a experiência vista. Entretanto, aquela atividade era de lazer, porém preservava dimensões que caracterizam as atividades de trabalho: regras, leis, planejamento anterior e, acima de tudo, a competição entre as equipes.

\footnotetext{
${ }^{111}$ Passamos uma tarde entre eles assistindo um jogo de futebol. Esse jogo foi organizado por um engenheiro e os participantes não eram os trabalhadores do grupo específico da pesquisa, porém, ficamos sabendo que esse é o modelo comum dos outros jogos locais. Em dois anos de observação não encontramos pessoas do grupo da Fábrica X, em nenhuma atividade fora do trabalho.

${ }^{112}$ A novidade, comentada pela coordenadora de Ginástica do SESI local, e que nos acompanhava nesse jogo, era que só recentemente as esposas dos que estavam jogando também participavam no momento destinado aos comes e bebes (expressão deles). Presenciamos nesse encontro conversas que giravam em torno de assuntos de trabalho.

${ }^{113}$ Conservas de cultura é: "o produto acabado de um esforço criativo (um livro, uma sinfonia musical, etc), fazendo parte do acervo cultural da sociedade. Envolve um processo espontâneo-criador desde a ação inicial até a sua finalização" (p. 15).
} 
A ginástica na empresa, foi citada em algumas respostas ao questionário como prática de lazer. Nas entrevistas, alguns também consideraram a única atividade diária de lazer. Para essas pessoas, esse é o sentido da ginástica na empresa. O lazer é conceituado como exercitação corporal na formulação da maioria deles.

O que percebemos na realidade pesquisada é que, para essa atividade existir, o sentido social deve estar diretamente relacionado à busca do equilíbrio orgânico do corpo e por via indireta ao equilíbrio social da cidade. Enfim, o que ficou mais evidente nas relações sociais existentes na cidade de Jaraguá do Sul, foi a busca constante - na maioria dos aspectos da vida humana - desse equilíbrio. Vale dizer, há uma uniformidade, uma linearidade, uma previsibilidade de tudo que é realizado nessa cidade. O trabalho produtivo é o que a move. Nada pode denotar foco de algum desequilíbrio (conflito, contradição) e para isto, a eficiência produtiva em tudo é exigida.

Essa eficiência é conseguida pelo seguinte tripé: trabalhar é o que dá dignidade as pessoas, a competência no trabalho é conseguida pelo sacrifício, dedicação, esforço pessoal, obediência e disciplina, sendo estes uma síntese dos valores morais de realização humana, quase idênticos aos valores da cultura da empresa pesquisada. O lazer como é visto como uma atividade menor (Lopes, 1998) quase não existe de fato, habitualmente, na cidade, apesar do empenho, se bem que recente, na efetivação de uma política pública de lazer da cidade.

Assim, vimos que para a maioria dos trabalhadores, a falta de tempo, dinheiro e cansaço são os maiores impedimentos para a prática de lazer, mesmo nos finais de semana. Nesse sentido, eles reforçam, de certa maneira, o encontro familiar aos domingos, como uma das principais práticas de lazer. Assim sendo, questionamos: como podemos, nessas circunstâncias concretas, dimensionar o sentido que essas pessoas conferem ao lazer? Elas definem lazer em relação a quê? Ao trabalho? O que seria lazer? E o tempo livre para esses trabalhadores, existe? 


\subsubsection{O CARÁTER SOCIAL DO LAZER, UMA NECESSIDADE HUMANA}

As relações sociais configuradas no trabalho dão a impressão de serem naturais, entretanto, Figueira (1989) afirma que o homem produz as suas próprias necessidades. Essas necessidades, produzidas nas relações de trabalho, são construídas socialmente, portanto, não são processos naturais. Com isso, queremos sustentar que o lazer como uma necessidade oriunda das relações de trabalho, engendra em seu seio, as influências desse mundo, ou seja, lazer, de uma forma ou de outra, relacionar-se-á com o trabalho, contrapondo-se ou adequando-se a ele.

Perguntamos aos trabalhadores se eles tinham necessidade de lazer, e, segundo os dados da tabela abaixo, do total das respostas obtidas constatamos que: $79,8 \%$ sentem essa necessidade, uns a enfatizaram - com muita, bastante necessidade, enquanto que 3,4\% afirmaram não tê-la e 17,8\% não responderam.

TABELA 24 - Necessidade de lazer

\begin{tabular}{l|c}
\hline Você sente necessidade de lazer? & N. $^{0}$ de respostas \\
\hline Sim & 80 \\
\hline Sim, mas não sobra tempo & 01 \\
\hline Sim, bastante & 02 \\
\hline Muito & 01 \\
\hline Ass vezes & 03 \\
\hline Bastante & 01 \\
\hline Um pouco & 01 \\
\hline Não responderam & 21 \\
\hline Com certeza & 02 \\
\hline Sim, mas falta dinheiro & 02 \\
\hline Não & 04 \\
\hline Total & 118 \\
\hline
\end{tabular}

O lazer é considerado uma necessidade, como confirmam as respostas dos trabalhadores entrevistados. Porém, a difícil caracterização das atividades de lazer e a diversificação das concepções apresentadas, confirmam que o lazer, como uma produção histórica, está circunscrito ao mundo subjetivo da pessoa e faz parte do campo das necessidades não-materiais. Entendemos assim que essa necessidade não significa uma atividade acessória, ou de luxo, mas um tipo de atividade que está se configurando na 
perspectiva do atendimento de uma questão básica, essencial para a continuidade e produção da vida, tanto quanto a necessidade de se alimentar.

\subsection{ATIVIDADES DE TRABALHO E LAZER, UMA SEPARAÇÃO INEVITÁVEL}

Explicitar e delimitar a diferença entre o trabalho e o lazer, tornou-se, a partir da diversidade encontrada nas respostas dos trabalhadores do grupo pesquisado, e na própria sistematização teórica existente, uma condição fundamental para sabermos se um tempo livre com lazer pode existir na vida dessas pessoas. Não conhecer essa diferença pode conduzir a uma compreensão ingênua, segundo Dumazedier (1973), simplificada. Essa simplificação pode camuflar o lazer da condição de ser uma necessidade, fruto do processo de organização do trabalho nas condições atuais em que se dá, e que, por isso, reflete carências que não estão sendo supridas nesse processo.

O lazer supõe o trabalho mas se distingue dele justamente por conta das características peculiares a que chegou o trabalho humano, na atualidade. $\mathrm{O}$ trabalho é atividade que assume um duplo caráter: é condição para se adquirir o provimento das necessidades básicas, o trabalho concreto, habitual, e também atende às demandas do modelo de produção social sob os parâmetros capitalistas.

Ao relacionarmos a essa questão o tempo e o trabalho assalariado verificamos, nesta pesquisa, que existe uma relação íntima entre o tempo do trabalho e o tempo total na vida dessas pessoas. Daí surge a dificuldade para separar os instantes na vida.

A compreensão de tempo que nos fornece o aporte teórico para conseguirmos entender e explicar os dados que foram detectados nessa realidade, é a do tempo como uma produção histórica da sociedade industrial, fruto de relações sociais e não da invenção do relógio; e que está organizado de forma parcelado, dividido em horas, dias, semanas, meses, anos. Essa divisão permite, dentre outras coisas, a efetivação das relações de trabalho através 
de medição da produtividade em tempo em que o que importa, em essência, é o resultado do que se faz, ou seja, o produto. Produzem mercadorias e não necessariamente realização humana. O tempo cronometrado viabiliza a forma de produção da existência moderna, mas, para o trabalhador, esse trabalho significa a obtenção da sua sobrevivência.

A organização do tempo dividido em horas permite divisões e fragmentações da vida em sua totalidade. Segundo Thompson (1991), a organização do tempo em época anterior à revolução industrial, apesar de não estar cronometrado e dividido da forma que o temos hoje, ocorria por uma orientação pautada na natureza. O nascer e o pôr do sol eram essa orientação. Mas, foi conjugando-se às mudanças desse momento da história, invenções, não só do relógio, mas da iluminação artificial, entre outras, que as condições para o abandono da natureza como referência à organização do tempo em relação ao trabalho se efetivaram. Nas atividades agropecuárias, a flexibilidade da jornada de trabalho fica enormemente determinada pelas condições circundantes do meio ambiente. $\mathrm{O}$ trabalho agropecuário só pode ser exercido à luz do sol. Tanto que um dia de trabalho sempre foi considerado a jornada que vai do amanhecer ao pôr-do-sol. Daí a expressão, até hoje repleta de sentido, trabalhar de sola-sol (Dal Rosso ,1996, p. 70) ${ }^{114}$

Thompson (1991) afirma que é o trabalho que dá a diretriz principal e a referência que de fato define essa orientação; em síntese, desde a época em que o relógio ainda não existia a atividade laboral era o elemento definidor do dia, semana, mês, ano.

Nesse sentido, segundo Cunha (1987, p.12), a jornada de trabalho e a relação com o desenvolvimento das forças produtivas não constituem uma relação de causa e efeito. A perspectiva de uma diminuição ou da definição quantitativa das horas trabalhadas, nas palavras do autor precede de que:

\footnotetext{
${ }^{114}$ Mais adiante esse autor escreve: Essa limitação da natureza prevaleceu durante grande parte da história humana. Ainda hoje grupos camponeses do interior do Brasil vivem como viviam seus pares há dois mil anos atrás, com as pequenas diferenças que fazem os parcos contatos com a cultura industrial e os escassos bens dela importados. Limpam o solo com a técnica da foice e do fogo como operavam os povos da Europa, quando ainda coberta de matas... E a jornada de trabalho também é regulada da mesma forma secular: no dia a dia pelo período iluminado pelo sol; durante o ano, pelo ciclo das estações; (p. 71)
} 
As forças produtivas e as relações sociais de produção não implicam o automático e contínuo declínio do tempo de trabalho. Elas são condições básicas, indispensáveis, mas não as determinantes. A luta política ${ }^{115}$ efetivada no interior das relações sociais é que constitui o estopim do recuo do tempo produtivo e da transformação desse tempo em outra coisa qualitativamente diferente, não produtiva.

Lafargue (1983, p. 48), no século XIX, defende "a diminuição da jornada de trabalho para 3 horas diárias". Porém, vimos que apesar de toda a ênfase dada por esse autor à crítica ao trabalho, sob o ponto de vista de que na sociedade capitalista o trabalho não ultrapassará a condição de aniquilamento humano e quanto mais se trabalha, mais a pessoa produz a sua miséria - portanto, deveríamos renegá-lo completamente -, os trabalhadores pesquisados não estão tendo essa análise.

Dessa forma, o tempo do trabalho, nessa fábrica, está organizado e obedece a uma ordenação que não a distingue de outras indústrias, tanto no que se refere à jornada de trabalho quanto à divisão em três turnos. A tabela abaixo, demonstra que, para a grande maioria $(80 \%)$ dos entrevistados, a jornada semanal de trabalho perfaz mais de quarenta horas.

TABELA 25 - Jornada de Trabalho

\begin{tabular}{l|c}
\hline Jornada de Trabalho & Porcentagem \\
\hline 40 Horas Semanais & $15,5 \%$ \\
\hline + de 40 Horas Semanais & $80 \%$ \\
\hline - de 40 Horas Semanais & $0 \%$ \\
\hline Não Respondeu & $4,5 \%$ \\
\hline Total & $100 \%$ \\
\hline
\end{tabular}

Considerando que esses trabalhadores gastam oito horas e oito minutos em seu dia no trabalho, o tempo recomendado de sono diário é de oito horas, restam daí sete horas e vinte minutos. Se a maioria desses trabalhadores gastam no transporte diário para ir e voltar de casa para o trabalho cinquienta minutos (uns gastam mais outros menos conforme a tabela exposta a seguir), temos ainda seis horas e trinta minutos.

${ }^{115}$ Grifo nosso 
TABELA 26 - Tempo gasto no percurso até o trabalho

\begin{tabular}{c|c}
\hline $\begin{array}{c}\text { Quanto tempo você leva para chegar ao trabalho? } \\
\text { Tempo/minuto }\end{array}$ & $\mathbf{N}^{\mathbf{0}}$ de respostas \\
\hline $05 \mathrm{~min}$ & 01 \\
\hline $07 \mathrm{~min}$ & 01 \\
\hline $10 \mathrm{~min}$ & 02 \\
\hline $15 \mathrm{~min}$ & 09 \\
\hline $20 \mathrm{~min}$ & 17 \\
\hline $25 \mathrm{~min}$ & 18 \\
\hline $30 \mathrm{~min}$ & 05 \\
\hline $35 \mathrm{~min}$ & 02 \\
\hline $40 \mathrm{~min}$ & 10 \\
\hline $45 \mathrm{~min}$ & 06 \\
\hline $50 \mathrm{~min}$ & 03 \\
\hline $60 \mathrm{~min}$ & 13 \\
\hline $80 \mathrm{~min}$ & 01 \\
\hline $90 \mathrm{~min}$ & 03 \\
\hline &
\end{tabular}

As seis horas e trinta minutos restantes seriam o resíduo, o tempo que restou para fora do trabalho. Porém, ainda existem necessidades humanas básicas, como a alimentação que todos devem atender, ou correm o risco de não conseguir desempenhar bem o trabalho. Outro exemplo pode ser a higiene pessoal que, inclusive, é uma exigência da empresa e está claramente exposta no Manual do colaborador, sob a recomendação de andarem sempre limpos e com roupas adequadas. No total, supondo que se gasta nessas tarefas o equivalente a umas três horas, isso se o ritmo for intenso nas atividades, restam ainda três horas e trinta minutos. Sabemos, porém, que a vida de qualquer pessoa exige também outras solicitações que não podem ser dispensadas, visto que em sua falta haverá, conseqüentemente, quebra de continuidade em seu conjunto.

Mais da metade de pessoas entrevistadas nessa fábrica, possuem uma composição familiar de quatro pessoas. A maioria é casada e, possivelmente, as tarefas correspondentes aos afazeres domésticos englobarão essas últimas três horas e trinta minutos. Observamos esses dados na tabela próxima. 
TABELA 27 - Número de pessoas na família

\begin{tabular}{l|c}
\hline Número de Pessoas na Família & Porcentagem \\
\hline Até 2 Pessoas & $20,97 \%$ \\
\hline Até 4 Pessoas & $54,72 \%$ \\
\hline Até 5 Pessoas & $16,91 \%$ \\
\hline Até 7 Pessoas & $7,40 \%$ \\
\hline Total & 100,00 \\
\hline
\end{tabular}

A partir dessas distribuições de horas, compreendemos por que a maioria dos entrevistados afirmaram categoricamente que não disponibilizavam de tempo para realizar atividades de lazer fora do trabalho e, ao responderem ao questionário sobre a dificuldade que teriam para efetivá-las, a falta de tempo também foi determinante. Já quando perguntamos de quantas horas eles dispunham para o lazer, uma parcela significativa referiu-se ao final de semana:

TABELA 28 - Disponibilidade de horas para lazer

\begin{tabular}{l|c}
\hline Quantas horas você dispõe para o lazer? & $\mathbf{N}^{\mathbf{0}}$ de respostas \\
\hline Não respondeu & 29 \\
\hline Não tem & 07 \\
\hline Sábados e Domingos & 16 \\
\hline Depende da semana & 04 \\
\hline Só no Sábado & 04 \\
\hline Só Domingo & 01 \\
\hline Até 5 horas & 32 \\
\hline De 6 até 10 horas & 09 \\
\hline De 10 horas em diante & 06 \\
\hline Poucas horas fico mais tempo na empresa; & 01 \\
\hline Tempo que sobra descanso; & 01 \\
\hline Não responderam & 08 \\
\hline Total & 118 \\
\hline
\end{tabular}

O tempo repartido em horas implica, necessariamente, uma divisão na vida dos trabalhadores. Essa divisão caracteriza-se por uma produção humana justificada em virtude das mudanças ocorridas através do desenvolvimento de tecnologias e de invenções que transformaram a base técnica do trabalho, fazendo necessária uma organização que não mais tivesse o nascer e o pôr do sol como referência. Porém, essas invenções surgem a partir das necessidades criadas pelo modo como desenvolvemos a produção da existência e não por obra 
da natureza. O tempo cronometrado, infelizmente, exerce influência na vida de qualquer pessoa, independente de sua vontade, pois a vida é continuum, em que descanso, trabalho, tempo livre e lazer estão, indissociavelmente ligados.

Ora, a matematização do tempo organiza praticamente todas as instâncias da vida humana e influi sobremaneira nas práticas de lazer. Daí a viabilização do lazer como o uso de um tempo residual, como a parte que sobrou depois do trabalho. O tempo relaciona-se com o lazer, através destas divisões: horas para se trabalhar, horas para o lazer, horas para dormir etc.

Se partirmos de uma compreensão de tempo, considerando a sua totalidade, veremos que somente se enxerga a possibilidade de dividirmos esse tempo em partes iguais, como a originada pela reivindicação dos trabalhadores. Entretanto, essas partes, necessariamente, não precisariam estar divididas dessa forma. O tempo de trabalho obedece a quê padrão? O que justifica, nos dias atuais, oito horas diárias de trabalho como a jornada de trabalho ideal?

O parâmetro da divisão do tempo em horas é o econômico, segundo Cunha (1987). Tempo repartido em cima da necessidade de produção das mercadorias, esse é o tempo necessário para que se produza o suficiente para a manutenção e continuidade da empresa, competindo nacional e internacionalmente com os seus produtos de excelente qualidade, e não um que considere o quanto a pessoa pode realizar sem se desgastar por completo.

A jornada de trabalho ${ }^{116}$ de mais de quarenta horas semanais é vista pelos trabalhadores como algo normal, sem incitar grandes questionamentos. Ao perguntarmos para um deles como ele via essa divisão, obtivemos a seguinte resposta: normal, perguntamos, então, se ele achava que deveria diminuir: não, não precisa (Anexo 6).

O trabalho em suas relações sociais, é que mesmo nos séculos anteriores à revolução industrial já definia a organização do tempo. Dessa forma, compreendendo-o sob o ponto de vista da cronometragem das horas, o temos como resultado do desenvolvimento

\footnotetext{
${ }^{116}$ No livro: A jornada de trabalho na sociedade, o castigo de prometeu (1996) de Sadi Dal Rosso, encontramos análises detalhadas sobre essa questão.
} 
social das relações humanas a partir da produção de sua existência, e não como naturalmente concebido. Para organizar o trabalho, definem-se as vinte e quatro horas do dia.

Torna-se evidente, mais uma vez, o pouco tempo de que eles dispõem para usufruir com atividades de lazer. Mesmo nos finais de semana, a quantidade de horas dedicadas ao lazer é reduzida.

Se hoje dividirmos esse tempo total em tempo para o trabalho, tempo para o atendimento às necessidades básicas de sobrevivência e tempo com uma leve sensação de liberdade (tempo livre), teremos como resultado final uma conta negativa, pois para obter um tempo livre, teríamos de obter saldo positivo, ou seja, depois de subtrair o tempo que se gasta no trabalho e nas atividades básicas (sono, alimentação, necessidades fisiológicas, higiene, incumbências domésticas ), deveria sobrar tempo suficiente e que pudesse ser usufruído para si.

Cunha (1987) apresenta duas classificações para o tempo: tempo produtivo e tempo não-produtivo. O tempo produtivo é aquele em que se produzem as riquezas materiais potencialmente aproveitáveis para toda a sociedade. Tempo não-produtivo é aquele em que tem valor também produtivo, também para a sociedade, porque este é tempo usado para recuperar as forças e proporcionar as condições para se consumir (através de viagens, dos restaurantes, compras ). Nas palavras do autor: "... resgata as condições mínimas de retorno da força viva de trabalho e libera os indivíduos para o consumo" (p. 13)

Entendemos também que horário de trabalho (jornada de trabalho) não deveria ser confundido com tempo de trabalho, tendo em vista poder uma pessoa realizar atividades num horário fora do trabalho e elas, mesmo sendo realizadas num tempo fora do expediente, devam ser para o trabalho, como já apontamos acima. O motivo de se estar fora do trabalho (das instalações físicas, do espaço) não é suficiente para caracterizá-las como atividades de lazer. A característica da atividade em sua finalidade é que vai definir se é uma atividade de trabalho ou não.

Tempo livre não seria muito mais que horas livres, sem parâmetros delimitadores para a existência prática das atividades? Vimos que o tempo é uma condição exterior, 
apontada, pelos trabalhadores entrevistados, como o fator que proporciona a maior dificuldade para a existência concreta de um tempo livre com lazer nas suas vidas.

Entendemos, enfim, que atividade como expressão humana, ou seja, a atividade que realiza as transformações das coisas tendo uma finalidade. A adaptação e a transformação do que se tem na natureza, de acordo com as necessidades atuais, são realizações necessárias e ao mesmo tempo em que vamos resolvendo essas necessidades vamos criando outras, num processo contínuo, como a necessidade de lazer da sociedade capitalista urbano-industrial.

Para imprimir a distinção entre o trabalho e o lazer, reportamo-nos ao elemento lúdico para compor o conteúdo dessas atividades, porém sem isolá-las de uma relação social, pois entendemos que uma atividade lúdica pode ser apenas uma chave que pode abrir a possibilidade de se agir, sem outro propósito que não o de expor a criatividade, o pensamento; enfim, atividades que se consomem na própria ação.

Logo, a possibilidade de se brincar nas atividades que podem ser as de lazer,- por sua natureza lúdica, está diretamente relacionada à improdutividade (Huizinga, 1993), à inutilidade para a produção das mercadorias, porém, com muita utilidade para a existência humana, num tempo livre do trabalho.

O lazer pode, não somente se constituir como atividades que contribuem na reposição da energia gasta no trabalho exaustivo, originada no conjunto das relações da sociedade urbano-industrial capitalista, mas também apresentar-se como atividades que suprem as faltas e carências. Vale dizer que não deixam de ser expressões desse tempo e dessas relações sociais.

Para os trabalhadores entrevistados, não existe unanimidade na eleição de atividades que mais proporcionam diversão e satisfação, fazendo-nos entender que elas podem suprir necessidades pessoais, atendendo a faltas e carências particulares de forma ampla e com um caráter muito pessoal

$\mathrm{Na}$ tabela a seguir classificamos as diversas atividades declaradas pelos respondentes da pesquisa: 
TABELA 29 - O que mais diverte e satisfaz

\begin{tabular}{l|c}
\hline O que mais lhe diverte e dá satisfação? & N. $^{\mathbf{0}}$ de respostas \\
\hline $\begin{array}{l}\text { Atividades sociais que promovem encontros com a família e com } \\
\text { amigos }\end{array}$ & 56 \\
\hline Atividades variadas que distraem .... & 29 \\
\hline Atividades físicas esportes- & 16 \\
\hline Quando os projetos dão certo & 04 \\
\hline Atividades que proporcionam bem estar, saúde, paz & 03 \\
\hline Atividades que proporcionam prazer & 03 \\
\hline Não sabem & 02 \\
\hline Atividades lúdicas & 02 \\
\hline Atividades fora do tempo de trabalho & 02 \\
\hline Trabalhar na empresa & 01 \\
\hline Mexer no computador & 01 \\
\hline Atividades religiosas (ir à igreja) & 01 \\
\hline Total & 120 \\
\hline
\end{tabular}

Observamos que trabalhar na empresa, para um desses trabalhadores, é uma atividade divertida e que traz satisfação. Consolida-se, assim, a nossa compreensão de que as atividades em si não adquirem autonomia que possa identificá-las como de lazer, mas, somente em relações conseguiremos distingui-las.

As respostas dos trabalhadores que foram consultados sobre a concepção de lazer confirmam que esse terreno é bastante movediço. Vimos também que o tempo de trabalho, ao absorver habitualmente a vida dessas pessoas, impossibilita a existência concreta de uma prática de lazer num tempo livre.

Constatamos ainda que a confusão conceitual sobre o lazer encontrada na produção acadêmica parece advir da própria materialidade. Dependendo da dimensão que se priorize e a partir do enfoque teórico do quadro de referência utilizado é que as explicações se dirigem, pois a separação entre trabalho e lazer não está nítida. As respostas ${ }^{117}$ dos trabalhadores expressam, desse ponto de vista, o que a própria realidade produz: uma nebulosa linha separando trabalho e lazer.

\footnotetext{
${ }^{117}$ Nesse sentido é oportuno relembrar que as respostas do trabalhadores foram adquiridas com perguntas abertas e elas são frutos da elaboração deles.
} 
Supúnhamos, no entanto, que lazer, em sua dimensão conceitual e, principalmente, em sua dimensão prática, somente poderia obter uma maior clareza e mais exatidão partindo das relações do trabalho.

Vimos que os limites apreendidos na realidade pesquisada, e que são originados dessas relações, confirmam que para serem ultrapassados seria necessário atingir a consciência social dessas pessoas sob outro ponto de vista. O sentido seria o de compreendermos que, para realizar atividades de lazer, temos de ter disponibilidade de tempo fora do trabalho bem maior do que existe nos dias atuais. O salário também deveria propiciar condições de compra para além das de subsistência. As atividades, sendo preenchidas com o lúdico, poderiam inutilizar o sentido de produtividade comum na produção de mercadorias, consubstanciadas tanto no brincar quanto na elaboração da realidade concreta a partir de novas referências, e não somente com a da cultura da empresa, por exemplo. Porém, a falta de tempo é o que não permite tal condição.

A orientação da vida social e individual desses trabalhadores, nessa cidade, é o trabalho, em suas relações gerais e, sem dúvida, nas relações internas da fábrica. Pareceu-nos que não há outra opção: ou se organiza a vida para o trabalho, ou se é marginalizado socialmente.

As atividades laborais sendo consideradas como de lazer podem promover uma limitação na possibilidade de se conquistar a diminuição da jornada de trabalho como uma conquista do ser humano para atender à necessidades não orientadas à produtividade de uma Fábrica, mas a de uma necessidade humana, para si.

Um dos aspectos sobre a concepção de lazer desses trabalhadores que merece destaque é que eles entendem o tempo livre não apenas como descanso, mas o usufruir desse tempo em outros sentidos. Transcendem, assim, a finalidade do descanso e o sentido reparador. A partir dos dados coletados foi possível verificar, entretanto, que esses trabalhadores exercitam práticas de lazer centrados no que está socialmente disponível e não no que eles concebem e mais gostam de realizar como lazer.

Parece que as relações entre o tempo de trabalho e o de lazer evidenciam conexões contraditórias. Essa relação constitui, para Parker (1978, p. 89), a continuidade 
(extensão) do trabalho, a oposição a ele ou, ainda, uma relação neutra. Segundo o autor, quando há extensão do trabalho, é uma atividade que "caracteriza-se basicamente pela similaridade entre algumas atividades de trabalho e lazer e pela falta de demarcação entre trabalho e lazer".

Quando se opõem ao trabalho:

[...] é a falta de similaridade intencional entre trabalho e lazer e a nítida demarcação entre as duas esferas" e por último, quando há uma neutralidade nessa relação" é apenas uma parte definido por um conteúdo 'geralmente diferente' de trabalho e lazer e por uma demarcação 'média' de esferas". Observa ainda o autor que esse último aspecto "não representa a posição intermediária entre os dois outros padrões porque denota mais uma separação do trabalho do que uma ligação positiva ou negativa (p.89).

Seria um tipo de atividade em que a pessoa não se posiciona, não se coloca, como alguns dos trabalhadores ao declararem que não sabem o que é lazer.

Enfim, trabalho e lazer são atividades humanas que não podem se identificar. $\mathrm{O}$ lazer não pode absorver o trabalho, nem o trabalho pode converter-se em lazer. O lazer possui características específicas que, embora o trabalho possa interferir nelas, mesmo assim, não podem ser a mesma coisa. Ambos mantêm uma relação mútua que conserva, ao mesmo tempo, características particulares, isto é, um não absorve o outro, mas eles também não se excluem por completo. Tanto o trabalho, quanto o lazer situam-se no espectro das atividades humanas, ligadas fundamentalmente à sobrevivência.

O lazer supõe o trabalho mas se separa dele a partir da divisão do tempo da vida da pessoa em horas e da diferença entre uma atividade que se realiza para si e uma atividade que se realiza para outrem. 


\subsection{A VARIABILIDADE DO LAZER SEGUNDO A PERCEPÇÃo dos Trabalhadores PeSQUiSAdos}

A variabilidade de atividades definidas como lazer leva Parker (1978) a afirmar que lazer é um conceito carregado de juízos de valor e de preferências. Se o entendermos apenas como realização de atividades que podem expressar o lúdico, podemos não conseguir distingui-lo do trabalho. A atividade em si não oportuniza uma configuração que exponha características essencialmente de lazer ou não, mas, se tivermos claro que para as atividades serem consideradas de lazer exige-se que o seu exercício seja num tempo livre do trabalho e que a finalidade se dirija para o desenvolvimento das potencialidades humanas, nessa configuração propiciaríamos diferenças.

O lazer, apesar de ser expressão de uma necessidade construída socialmente, não pode ser dimensionado apenas individualmente. São as condições e organização do trabalho, nessa realidade, em seu tempo cronometrado, que podem definir as possibilidades ou não de sua existência. A valorização do ser humano na empresa pesquisada não se realiza se os trabalhadores não possuírem condições de uma vida pessoal, parafraseando Antunes ( 1995) 'cheia de sentido', num tempo livre.

Ou seja, constatamos, a partir dos dados levantados nesta pesquisa que não há falta de elaboração ou de vontade dessas pessoas. Porém os impedimentos para existir de fato tempo livre com lazer na vida delas são causados por fatores exteriores à vontade pessoal. Portanto, o lazer não pode ser entendido apenas como um estilo de vida ou como simplesmente uma questão de atitude. O que seria enfim lazer para estes trabalhadores? Há uma grande dificuldade quando se trata de definir quais e o que são atividades de lazer, tanto para esses trabalhadores, quanto para os pesquisadores; pois esse é um tema de difícil caracterização. Por conseguinte, não é só para os trabalhadores que essa conceituação é complexa e multifacetada em sua significação. A confusão ou a ambigüidade, como escreve 
Dumazedier (1985), estão postas também para os que estudam e pesquisam esse assunto. Surge daí uma multiplicidade de conceitos que redundam em grandes polêmicas ${ }^{118}$.

\section{Para alguns trabalhadores lazer é:}

... Tudo que proporciona prazer, uma coisa gostosa. Pode até ser no trabalho ou praticando esportes, num descanso;

... Final de semana pegar a família ir na piscina, nas férias ir à praia, quando dá;

... Passear, jogar futebol;

... Passear, ficar em casa;

... Jogar uma bolinha, no verão pegar uma praia;

... Passear, fazer passeio ecológico;

... Jogar futebol;

... Jogar bola, baralho, brincar na piscina;

... Jogar Vôlei, andar de bicicleta;

... Gosto de TV, ler revista quando posso, passear na casa de amigos, parentes, estudar;

... Nos finais de semana, na semana não há tempo;

... Passear com a família.

Das respostas do grupo pesquisado, foi possível constatar que as várias concepções sobre o lazer coincidem com a confusão conceitual nas publicações sobre o tema. Portanto, a variabilidade de compreensões sobre o lazer parece resultar num emaranhado de noções que se tornam difíceis de ser explicitadas à primeira vista. Desse modo, tais respostas, são, talvez, expressão ${ }^{119}$, da própria realidade. Vejamos mais algumas respostas:

... Lazer para mim é fazer o que você gosta mais de realizar durante a sua folga e curtir os nosso filhos porque eles estão crescendo e nem percebemos o seu desenvolvimento;

... Passear com a família e sair da rotina do dia-a-dia;

\footnotetext{
118 Tentaremos montar um quadro panorâmico sobre essa questão, a não unanimidade sobre o que poderia ser lazer.

${ }^{119} \mathrm{Na}$ coleta de dados, não definimos nenhum conceito de lazer ou de qualquer outra questão, sempre procurando as respostas a partir da compreensão deles.
} 
.. Poder se divertir, praticar esportes, ter tempo para ficar com a família, poder ir passear etc;

... Passear no shopping, jogar bola com meu filho, levar meu filho para jogar vídeo game. Sempre com a família;

... Passear, caminhar, ir às compras, dançar, pescar, bater papo com os amigos;

... Passear, ir à praia, viajar etc. Sem dívidas para não ficar pior quando voltar.

Segundo Parker (1978) existem três formas de definição de lazer: a primeira é a residual, considera o tempo que se gasta no trabalho; a segunda é a que não considera a questão do tempo, mas a qualidade da atividade, vinculando-a à possibilidade de extrapolar as regras socialmente aceitas; já a terceira maneira de definir lazer é a que combina tanto a dimensão do tempo, quanto da atividade, acompanhando proposições de como o lazer poderia ser.

Sobre isso, entendemos que além de unir as dimensões do tempo, qualidade da atividade e a elaboração de proposições, é importante, nesse contexto, incluir mais um elemento que é o lúdico e a sua relação ao trabalho. Para nós, esse elemento promoverá características de lazer, como atendimento a uma necessidade não material, criada nas relações de trabalho existentes, e, por isso, estritamente ligada às condições da produção da existência. Por esse eixo, a natureza improdutiva das práticas lúdicas somente fará sentido se elas forem realizadas num tempo livre do trabalho; então, não seria somente o componente do lúdico que garantiria uma prática de lazer, mas também uma relação subordinada ao tempo livre do trabalho.

O lúdico, como um componente que pode ser conjugado com o lazer no sentido de contribuir para uma menor ambigüidade sobre a compreensão do lazer, impõe-se, como pressuposto a esse tipo de atividade, que elas sejam realizadas num tempo livre do trabalho, para as pessoas que vivem no assalariamento. Ou seja, sem nos esquecermos de que esse tempo será sobra do tempo de trabalho. Vislumbramos também a necessidade de fruição dessas atividades lúdicas intrínsicamente relacionada às de lazer. Elas têm por exigência própria um descompromisso com o tempo, é algo devagar, lento, usando aqui a conceituação de Covre (1996), e por isso apresentam uma certa incompatibilidade com a cronometragem do tempo, exigida no trabalho produtivo, e a racionalidade econômica como afirma Padilha (1995). 
$\mathrm{O}$ conceito que mais influencia as produções sobre o lazer ${ }^{120}$, segundo Marcelino (1990) é o de Dumazedier ${ }^{121}$ (1973), de acordo com o que ele observa, é o conceito utilizado em vários estudos independentemente da área ou enfoque de atuação, indo da sociologia à educação física. Para Dumazedier (1973, p. 34):

O lazer é um conjunto de ocupações às quais o indivíduo pode entregar-se de livre vontade, seja para repousar, seja para divertir-se, recrear-se e entreter-se ou, ainda para desenvolver sua informação ou formação desinteressada, sua participação social voluntária ou sua livre capacidade criadora após livrar-se ou desembaraçar-se das obrigações profissionais, familiares e sociais.

Já para Marcelino (1990, p. 31), lazer é entendido como "a cultura - compreendida no seu sentido mais amplo - vivenciada (praticada ou fruída) no tempo disponível". Esse autor evidencia o caráter desinteressado dessa vivência, em que vale basicamente a satisfação causada pela situação, nada mais que isso.

Não há unanimidade teórica em relação também ao conceito de ócio, de recreação, do lúdico, do tempo livre e do lazer. Para muitos, parecem significar a mesma coisa. Porém, se utilizarmos o sentido etimológico ou histórico desses conceitos, veremos que podem existir diferenças e algumas aproximações entre uns e outros.

O sentido etimológico explicado por Marinho (1984 p.195)) em seu livro: Introdução ao Estudo da Filosofia da Educação Física e dos Desportos é:

Lazer deriva do latim licére, que significa ser lícito, ser permitido. A forma arcaica era lezer, que originou outros derivados. O mesmo verbo licere (to be permitted) originou em inglês a palavra leisure e, em francês, loisir, significando o tempo que fica disponível depois das ocupações usuais. Em espanhol não encontramos o termo lazer, mas tão somente ócio, em italiano também ocorre o mesmo, ozio, oziocitá.

Já para a palavra ócio o autor (p.195) escreve: "[...] também de origem latina (otium), significa, a rigor, retirado do negócio (negotium). Assim, otium e negotium são opostos".

\footnotetext{
${ }^{120}$ No Brasil, segundo Marinho (1984), o primeiro autor que utilizou a palavra Lazer, no título de um trabalho publicado foi Acácio Ferreira em 1959. Foi ele também quem fez a primeira pesquisa sobre o Lazer de trabalhadores.

${ }^{121}$ Jofre Dumazedier é um sociólogo francês, precursor dos estudos do lazer no mundo, inscreve-se na área da sociologia do lazer, ou melhor localizando, inaugurando a sociologia empírica do lazer.
} 
A conclusão do autor (p. 196).é:

[...] poderemos distinguir lazer de ócio, dizendo que aquele é o tempo liberado de quem trabalha e este o tempo disponível de quem não mais trabalha ou, simplesmente não trabalha. Assim, o trabalhador desempregado não tem horas de lazer, mas de ócio e isto porque o lazer é próprio somente daquele que trabalha. Os gregos não conheceram o lazer como hoje o entendemos, mas tão somente o ócio

Marinho (1984) distingue o ócio do lazer. A diferença, para esse autor, está na relação com o trabalho: o tempo disponível que resta depois do trabalho pode corresponder, ao lazer. Para ele, só tem lazer quem trabalha. O ócio é para quem não trabalha: aposentados, desempregados etc.(na sociedade contemporânea). A subordinação do lazer ao trabalho para este autor, é clara.

Voltando-nos para o ócio, segundo De Grazia (1966), o ócio é expressão da sociedade grega. Entretanto é necessário termos claro que algumas categorias ou os conceitos perdem o seu sentido em relação aos contextos históricos, outros não, quando estes ainda expressam algo do real.

O ócio, sendo herança grega, recebe a influência da concepção Aristotélica de possibilidade de crescimento humano (Marinho, 1984). Hoje, o ócio não se apresenta mais com esse sentido ( o da idade antiga). $\mathrm{O}$ ócio não é bom ou ruim, as relações modernas é que não fortalecem mais esse ideário, o ócio deixou de ser sinônimo de crescimento humano, cedeu vez ao trabalho.

Na sociedade contemporânea, através da palavra ociosidade, o ócio ganha o sentido de não se fazer nada. É visto como a mãe de todos os vícios. A atividade contemplativa adquiriu por influência, possivelmente da racionalidade econômica, um teor pejorativo, sinônimo de preguiça, de malandragem. De Masi (2001) vem defendendo o ócio como possibilidade criativa, porém, ele também concorda que existe essa conotação menor através da palavra ociosidade.

Segundo Dumazedier (1973), a relação estabelecida entre trabalho e lazer por alguns estudiosos do tema também não é unanimidade. Para uns, o lazer complementa ou compensa o trabalho desumano, para outros, o lazer influencia o trabalho. Mais adiante, o 
autor afirma que: "devemos repetir, no entanto, que no estado atual das pesquisas, não passam de hipóteses as idéias referentes às relações entre o trabalho e o lazer - falta uma rigorosa verificação de todas elas" (p. 97). A referência desse autor é o contexto europeu.

Voltando ainda ao ócio, De Grazia (1966) problematiza-o afirmando: o tempo livre que os gregos dispunham para exercitar o ócio, existia em função do trabalho escravo, ou seja, existia para alguns privilegiados que eram livres do trabalho. O modelo de produção da sociedade antiga era escravista, e a produção da existência estava a cargo dos escravos. Eles eram os responsáveis pela produção das condições materiais para a classe privilegiada usufruir do ócio. O trabalho, mais braçal, era sinônimo de degradação.

De acordo com o exposto, podemos concluir que o ócio como expressão da sociedade antiga possui um conteúdo histórico que expressa bem sua época. O lazer, porém, é próprio da época do trabalho industrial e só tem sentido no modo de produção da existência capitalista. Segundo ainda Marinho (1984), o lazer só começou a existir em conjugação com a conquista, através da luta dos trabalhadores, da diminuição da jornada ${ }^{122}$ de trabalho. Os trabalhadores das minas de carvão inglesa, no século XIX, é que iniciaram essa luta. Chamanos a atenção (p. 197) a canção que esses trabalhadores entoavam, cujos versos ${ }^{123}$ diziam :

\section{Eight hours to work, Eight hours to play, Eight hours to sleep, Eight shillings a day}

$\mathrm{O}$ autor explica que esses trabalhadores uniam atividades de cunho recreativo, e com o lúdico, à luta para a conquista de uma diminuição de horas no trabalho. Eles cantavam e reivindicavam o lazer por meio da música.

A recreação, um outro termo que, vinculado ao lazer, acaba passando um entendimento restrito de atividade física como lazer. Segundo Marinho ${ }^{124}$ (1955), ele se

\footnotetext{
${ }^{122}$ Segundo Marinho (1984, p. 197) no século VI os monges beneditinos passavam, no mundo que eles criaram e disciplinaram, oito horas dormindo, oito horas rezando e oito horas no trabalho braçal (principalmente na agricultura).

${ }^{123}$ Oito horas para o trabalho, oito horas para o lazer e oito horas para o descanso e oito shillings por dia. (xelim: moeda inglesa que era equivalente a 5 pence, hoje extinta).

${ }^{124}$ Este livro apesar de ser bem antigo foi um que apresentou de forma mais sistematizada a relação entre a recreação, a escola e as correlações entre esta e os Parques infantis - os jardins, nos explicando como
} 
vincula às atividades físicas pela recreação, nos jogos e brincadeiras com características de busca da alegria, do prazer e da liberdade do fazer, por conta da origem vinculada ao recreio. Segundo esse autor, essa influência é americana. No entanto, já aconteceu a absorção mais ampliada desse conceito com outros elementos e, nos dias de hoje, a recreação já se confunde com lazer, não admitindo mais uma divisão de atividades que, para as crianças significam recreação e para os adultos lazer. Tudo é uma coisa só.

Assim, a configuração para o lazer deveria estar diretamente relacionada ao desenvolvimento das potencialidades humanas para si e não para melhorar a produtividade na empresa, cujos produtos carregam, de maneira sutil e oculta, o tempo total da vida destas pessoas.

Se uma atividade está dirigida a uma finalidade exterior à pessoa, como por exemplo produzir motores elétricos, essa atividade atende a uma finalidade da empresa e não da pessoa. A pessoa pode executá-la de forma prazerosa e até criativa, isso também não importa. Enfim, a atividade em si não a caracteriza como de lazer ou de trabalho, a finalidade relacional é que lhe confere o seu sentido.

Por exemplo, quando se estuda para melhorar o desempenho em certas habilidades pessoais de forma a aperfeiçoar a produção de motores elétricos, tal formação é uma atividade que pode ser realizada fora do horário de trabalho. No entanto, ela consome um tempo de trabalho. Para alguns trabalhadores, isso está claro: Estudo, mas estudo não é lazer; Outro entrevistado diz: Todo dia não tenho lazer, porque trabalho e estudo.

Portanto, a caracterização de atividades que possam assumir um estatuto de atividades de lazer deve, para ser encontrada, obedecer primeiramente a uma conta de subtração. Se são gastas oito horas e meia por dia no horário de trabalho, mais três em média no trajeto de ida e volta de casa para a empresa, mais umas cinco para atender às necessidades básicas, mais quatro para a manutenção das questões domésticas e mais oito para o sono então extrapolamos as vinte e quatro horas do dia. Essa conta não está sendo exata. Faltam horas

historicamente foi concebido. O nome de Jardins de infância, a partir da relação entre as atividades de recreação (jogos e brincadeiras em espaços livres) e os espaços abertos, no desenrolar do tempo foi se denominando de Parques infantis. 
para a simples reprodução da vida. O lazer, que está contido nessa reprodução, não está sendo oportunizado nem para reposição de energia.

Alguns dos trabalhadores entrevistados confirmam a falta de tempo para lazer:

... eu trabalho no horário normal e o tempo é curto, a gente chega em casa as 18:00 horas para tomar um banho e querer descansar;

...ter o cara tem, mas as condições são bem precárias, às vezes não tem dinheiro, não é bem fácil;

... tenho. Chego em casa relaxo, o relaxamento para mim é um Lazer; Tenho todo dia, 2 horas por dia, brinco com meu filho, vou à igreja;

... muito pouco, só nos finais de semana;

... a gente tira o tempo. Quando é possível a gente procura ocupar o tempo fora do trabalho.

Outros, ao explicarem por que não dispõem de tempo para o lazer, evidenciam na fala dificuldades que estão direta ou indiretamente relacionadas ao trabalho. Vejamos algumas delas: Trabalho, estudo, não sobra tempo nem para dormir, agora que estou vindo de ônibus, durmo apenas três horas e meia por noite; Outro inclui o trabalho doméstico: Passo o dia em meu trabalho e estudo, nas poucas horas que tenho fora disso tenho o trabalho de casa. Mas, é a jornada de trabalho e a limitação financeira os motivos mais presentes:

Durante a semana, durante o trabalho não tenho tempo, pois o trabalho na empresa retira muito a atenção durante o dia e tempo livre nos dias de semana são para o descanso;

Nos finais de semana, as tarefas domésticas precisam de mais atenção e também falta dinheiro para levar meus filhos à programas diferentes;

Tudo que você faz requer gastos que não dão para se encaixar no orçamento familiar;

A própria rotina do dia a dia, da casa à escola, da escola ao trabalho, do trabalho à casa e aí descansar;

Quando perguntamos o que eles fazem como atividades de lazer, responderam que se reúnem com a família. Em outro momento, perguntamos o que mais os divertia e lhes proporcionava satisfação, eles responderam que era o encontro com a família. Entendemos que para eles a conceituação de lazer realmente não está clara. Quando perguntamos sobre o 
que é lazer a maioria respondeu que é jogar futebol, quando perguntamos o que gostam de realizar, ou seja, pressupondo que o gostar, o sentimento de satisfação, de alegria poderia fundamentar a resposta, não foi essa a linha de raciocínio deles. Eles gostam é da reunião com a família e amigos, .mas concebem como atividade de lazer jogar o futebol.

Por tudo isso, constatamos a necessidade de ressaltar que não existe uma relação mecânica entre trabalho e lazer, mas uma relação contraditória, oriunda de relações humanas; portanto, rica em várias dimensões, e configurando-se como desdobramento do processo de organização do trabalho em sua delimitação do tempo. E, na concepção desses trabalhadores, o lazer existe com vários sentidos e conotações.

A nosso ver, a discussão conceitual, para ser atualizada no contexto do século XXI precisa considerar um pressuposto fundamental: a crítica à jornada de trabalho extenuante aliada à necessidade socialmente construída do lazer como uma necessidade humana. Todavia, o lazer não pode ser visto apenas como uma reposição da energia gasta no trabalho. Além de repor e recompor diariamente o que gasta no trabalho, o trabalhador possui necessidades humanas que envolvem práticas de criação, de elaboração, brincar, que precisam ser atendidas num tempo que vai além da divisão em horas do trabalho. Relembrando que o corpo que produz é o mesmo que brinca. A delimitação entre trabalho e lazer, na realidade atual, é necessária para evitar confusões entre um e outro.

Diante de toda a diversidade de compreensões e ações entendidas como de lazer, a conscientização sobre diferenças entre atividades de lazer e de trabalho realmente se faz necessária, pois essa distinção pode permitir a compreensão mais crítica de um direito que se efetivaria para atender a uma necessidade humana. 


\section{CONSIDERAÇÕES FINAIS}

Ao finalizar esta pesquisa concluímos que um tempo livre com lazer, figura, na vida dos trabalhadores pesquisados, como promessa de felicidade.

No confronto entre duas realidades supostamente distintas, a vida no trabalho e a vida fora dele, apreendemos elementos que unem essas duas instâncias, porém, expressandose como limites para a prática de atividades de lazer. São eles: o tempo cronometrado dispensado no trabalho, que promove a falta de tempo para si na vida fora do trabalho e o tipo da atividade laboral que os trabalhadores pesquisados desenvolvem dentro da fábrica. Ao atrelar a falta de tempo à atividade laboral cansativa, dolorida e estressante que eles realizam, percebemos que essas condições fazem com que esses trabalhadores vivam, na prática, somente para trabalhar na empresa, pois o tempo fora do trabalho é para descansar e se preparar para voltar ao trabalho.

Constatamos que os trabalhadores do grupo pesquisado sentem necessidade de lazer e têm consciência de que é a falta de tempo que não lhes permite a efetiva realização de lazer. Para eles a necessidade de se ter lazer está clara, porém, não é atendida devido as condições advindas das relações de trabalho. Logo, não é por falta de uma concepção mais elaborada deles sobre o lazer, ou, ainda, por falta de vontade pessoal que essa prática não está efetivada. Desta forma percebemos que é no conjunto das relações sociais da produção da existência material que os seres humanos criam e sentem necessidade de lazer, mas com uma contradição do próprio processo de trabalho: é nele que esta necessidade é criada, embora seja o próprio trabalho o que impede a sua satisfação.

Percebemos que a exaustão humana, fruto da atividade laboral realizada pelos trabalhadores dessa empresa, está sendo resolvida com a ginástica que realizam no horário de trabalho e que, constitui uma nova tecnologia organizadora desse trabalho, por atender, indiretamente e de forma subjetiva, o seu processo interno. Contudo, essa exercitação corporal orientada não se caracteriza como uma atividade de lazer, mesmo considerando o corpo sob um ponto de vista mais completo, que brinca, e menos fragmentado, como é próprio desse trabalho

Essa tecnologia confirma que uma atividade em si, isolada, não é condição suficiente para caracterizar prática de lazer, pois no exemplo desse Programa, a finalidade é a 
produtividade no trabalho. Portanto, o tipo de relação que se estabelece entre uma atividade e o seu fim é o que pode configurar e caracterizar com mais clareza se a atividade é de lazer ou não. Confirmamos ainda que brincar, ter prazer e alegria podem existir mesmo no trabalho, pois o corpo que brinca é o mesmo que produz. Porém, não é lazer, pois a finalidade da relação estabelecida é a consolidação de uma alta produtividade com baixo custo, na produção de riqueza alheia.

Essa tecnologia possui duplo caráter: promove o descanso e a recomposição imediata do ser humano, garantindo a continuidade da atividade laboral e, para o processo de trabalho, promove uma maior produtividade com baixo custo. Portanto, essa tecnologia fortalece a cultura da empresa, sendo um elemento fomentador e viabilizador dela, num sentido de convencimento de que esta empresa realmente se preocupa com o ser humano.

Percebemos que a ginástica na empresa como tecnologia organizadora do trabalho necessita de uma elaboração teórica que ultrapasse e inclua outras dimensões, além do pressuposto do corpo biológico, pois na prática pedagógica que acontece no chão da fábrica, ela está sendo exercitada também sob um viés que não se sustenta somente no corpo biológico.

Apesar de o processo de organização do trabalho da empresa em destaque sobressair-se em relação às demais e, considerando o empenho que ela faz na divulgação do seu caráter humanizador em seu processo interno de trabalho, ela deveria, se a preocupação fosse com o ser humano de verdade, dispor aos trabalhadores mais tempo livre do trabalho para exercitarem práticas de lazer (diminuir o tempo da jornada de trabalho). Parece-nos que a humanização para eles está restrita ao que pode contribuir para uma melhoria no trabalho na perspectiva de produtividade, mas, somente dentro da fábrica.

Por tudo isso, concluímos que o lazer não pode ser entendido sem levar em conta o trabalho, e não se explica apenas pelas atividades em si que são desenvolvidas, nem por permitir prazer, nem somente por características lúdicas, mas, é definido a partir da concretização de uma relação social em que se possa dirigir a atividade para o desenvolvimento de potencialidades humanas de auto-expressão, e não para a produtividade no trabalho. 
Outra constatação é que a implementação tecnológica nas bases produtivas, em si, não promovem tempo livre com lazer de uma forma direta. Essa relação não é de causa e efeito. Por conseguinte, existe um fator que não está explicitado nesse tipo de afirmação, que é a sujeição da ação humana às condições de trabalho que estão estabelecidas. Não serão máquinas, nem a microeletrônica que promoverão tempo livre com lazer, visto que a diminuição da jornada de trabalho, condição essencial para tal feito, só vem acontecendo como conquista da organização política dos trabalhadores. Nesse sentido, perguntamos: como esses trabalhadores poderão se organizar politicamente, se de tempo, muitas vezes, nem para dormir, eles dispõem?

Muitos autores até já chegaram a afirmar que estávamos numa sociedade de tempo livre e outros, nessa mesma linha, falavam que participávamos de uma revolução cultural do lazer. Sob outra perspectiva, também ouvimos que o trabalho já não era categoria central de explicação da realidade, nem elemento organizador da vida societal; assim, o lazer assumiria a base de novas sociabilidades mais criativas, pois estávamos numa sociedade pósindustrial promovida pelo desenvolvimento tecnológico. Contudo, este estudo constata que o lazer dificilmente acontece. Somente com um esforço pessoal ele é quase impossível, principalmente, para as pessoas que, para viver, precisam trabalhar.

Ainda, constatamos que o trabalho assalariado condiciona o tempo fora do trabalho impondo-se como tempo de reprodução da força de trabalho. Portanto, para obtermos tempo livre com lazer exige-se uma outra condição de construção/produção/reprodução da vida material/espiritual forjada sob outras relações sociais. 


\section{REFERÊNCIAS}

ACIJS - Associação Comercial e Industrial de Jaraguá do Sul. $1^{0}$ Censo industrial de Jaraguá do Sul. Jaraguá do Sul, nov., 1991.

ANTUNES, Ricardo. Adeus ao trabalho? Ensaio sobre as metamorfoses e a centralidade do mundo do trabalho. São Paulo: Cortez/UNICAMP, 1995.

Os sentidos do trabalho: ensaio sobre a afirmação e a negação do trabalho. São Paulo: Boitempo Editorial, 1999.

AZNAR, Guy. Trabalhar menos para trabalharem todos. São Paulo: Scritta/Página Aberta, 1995.

AUED, Idaleto. Teoria econômica e reforma curricular. In: Textos de economia. Florianópolis, jun/1987.

AUED, Bernardete W. Histórias de profissões em Santa Catarina: ondas largas "civilizadoras". Florianópolis: Ed. Do Autor, 1999.

BOLETIM DIEESE. A reestruturação produtiva no comércio. O pior ano para as negociações salariais. São Paulo: Ano XIX, jan/fev., 2000.

BONETTI, Albertina. Ginástica: em busca de sua identificação no âmbito escolar. Universidade Federal de Santa Catarina. Dissertação de Mestrado em Educação Física. Florianópolis, 1999.

BOSI, Ecléa. Cultura de massa e cultura popular: leituras de operárias. Petrópolis: Vozes, 1978.

BRACHT, Valter. Educação física e aprendizagem social. Porto Alegre: Magister, 1992.

BRECHT, Bertold. Teatro completo. Rio de Janeiro: Paz e Terra, 1991 (Coleção Teatro, vol. $9-14)$.

BRUHNS, Heloisa T. O culto do corpo-prazer, o fenômeno lazer e o lúdico. In: Revista Brasileira de Ciências do Esporte. Campinas, vol. 12 (1,2,3), UNIJUÍ, 1992.

CADERNOS ANDES. Educação e trabalho. Brasília, n. 10, out., 1993.

CAMARGO, Luiz O. L. O que é lazer. São Paulo: Brasiliense, 1989. 
CANEVACCI, Mássimo. (Org.). Dialética do indivíduo. O indivíduo na natureza, história e cultura. São Paulo: Brasiliense, 1981.

CARVALHO, Ruy de Quadros, BERNARDES, Roberto. Reestruturação industrial produtividade e desemprego. In: Revista São Paulo em perspectiva. São Paulo, 10 (1), Fundação SEADE, 1996.

CASTELlANi FILHO, Lino. Educação física no Brasil: a história que não se conta. Campinas: Papirus, 1988.

CELESC - Centrais Elétricas de Santa Catarina S/A. Boletins estatísticos 1991 e 1992. Diretoria de Engenharia e Operações. Área de Comunicação Social - ACS.

CHAUI, Marilena. Introdução. In: LAFARGUE, P. O Direito à Preguiça. São Paulo: UNESP/Edit. Hucitec, 1999.

CHESNAIS, François. A mundialização do capital. São Paulo: Xamã, 1996.

CODO, Wanderley. Indivíduo, trabalho e sofrimento: uma abordagem interdisciplinar. Petrópolis: Vozes, 1993.

CODO, W., ALMEIDA, M.C. (Orgs.). L.E.R. diagnóstico, tratamento e prevenção: uma abordagem interdisciplinar. Petrópolis: Vozes, 1995.

COLETIVO DE AUTORES. Metodologia do ensino de Educação Física. São Paulo: Cortez, 1991.

CORIAT, Benjamin. Automação programável: novas formas e conceitos de organização da produção. In: SCHMITZ, Hubert; CARVALHO, Ruy de Q. Automação, competitividade e trabalho: a experiência internacional. São Paulo: Hucitec, 1988.

. Pensar pelo avesso. Rio de Janeiro: UFRJ, 1994.

COSTA, Lamartine Pereira. Esporte e lazer na empresa. Fundamentos do lazer e esporte na empresa. Programa Esporte e Saúde.Ministério da Educação/Secretaria de Educação Física e Desportos.Ministério da Saúde/Secretaria Nacional de Programas Especiais de Saúde.1990.

COVRE, Maria de Lourdes M. A fala dos homens. Análise do pensamento tecnocrático 1964 - 1981. São Paulo: Brasiliense, 1983.

. Educação, tecnocracia e democratização. São Paulo: Ática, 1990.

Vogal, 1996.

No caminho de Hermes e Sherazade - cultura, cidadania e subjetividade. Taubaté: 
COX, Harvey. A festa dos foliões: um ensaio teológico sobre festividade e fantasia. Petrópolis: Vozes, 1979.

CRESPO, Jorge. A história do corpo. Lisboa: DIFEL, 1990.

CUNHA, Newton. A felicidade imaginada. A negação do trabalho e do lazer. São Paulo: Brasiliense, 1987.

DAL ROSSO, Sadi. A jornada de trabalho na sociedade: o castigo de Prometeu. São Paulo: LTr, 1996.

DE GRAZIA, Sebastian. Tiempo, trabajo y ocio. Madrid: Editorial Tecnos, S. A, 1966.

DE MASI, Domênico. Sociedade pós - industrial exige direito ao lazer. In: Jornal O Estado de São Paulo, domingo, 06 de março, Caderno Tendências, p. 3, 1994.

O Futuro do Trabalho. Fadiga e ócio na sociedade pós-industrial. Rio de janeiro: José Olympio; Brasília, DF: Ed. da UnB, 1999.

Ócio Criativo. Rio de Janeiro: Editora Sextante, 2000.

A economia do Ócio. Introdução. Rio de Janeiro: Editora Sextante, 2001.

DIEESE. Trabalho e reestruturação produtiva: 10 anos de linha de produção. São Paulo, 1994.

Florianópolis, 1996.

- Reestruturação produtiva e emprego na indústria de Santa Catarina. . Diagnóstico do complexo metal-mecânico brasileiro. São Paulo, 1998. Anuário dos Trabalhadores de Santa Catarina. Florianópolis, 1999.

DIEFENTHALER, Eliza M. R., JAGNOW, Egon L. e CANUTO, Alcioní M. Crescendo com a nossa história. Secretaria municipal de Educação/ Secretaria municipal de Cultura, Esporte e Turismo. Prefeitura Municipal de Jaraguá do Sul.

DUMAZEDIER, Jofre. Lazer e cultura popular. São Paulo: Perspectiva, 1973.

. Sociologia empírica do lazer. São Paulo: Perspectiva, 1979.

A revolução cultural do tempo livre. São Paulo: Studio Nobel: SESC, 1994.

ENGELS, Friedrich. A situação da classe trabalhadora na Inglaterra. São Paulo: Global, 1985. 
ESTUDO REGIONAL DIESSE. Qualificação, formação e emprego em Santa Catarina: quadro crítico da situação dos trabalhadores. Florianópolis, n. 2, dez/1997.

FECAM - Federação Catarinense de Associação de Municípios e AMVALI - Associação dos Municípios do Vale do Itapocu. Jaraguá do Sul, 1994 (Pré-Edição para o Seminário Levantamento de Dados - Sujeita a Alteração).

FERREIRA, Acácio. Lazer Operário, um estudo de organização social das cidades. Salvador: Livraria Progresso, 1959.

FIDALGO, Fernando S. (Org). Gestão do trabalho e formação do trabalhador. Belo Horizonte: Movimento de Cultura Marxista, 1996.

FIGUEIRA, Fani. G. Diálogos de um novo tempo. Universidade de São Paulo. Tese de Doutorado. Departamento de Sociologia. São Paulo, 1989.

FIOD, Edna G. M. A saga da escola alemã em Santa Catarina, 2002 (no prelo).

FOUCAULT, Michel. Vigiar e punir. Petrópolis: Vozes, 1986.

FRIEDMANN, Georges. Os lazeres e a insatisfação do trabalho, In: O trabalho em migalhas. São Paulo: Perspectiva, 1983.

FROMM, Erich. Conceito marxista do homem. $4^{\mathrm{a}}$ ed., Rio de Janeiro: Zahar, 1967.

GOLDENSTEIN, Gisela T. Lazer operário e consumo cultural na São Paulo dos anos oitenta. In: Revista Administração de Empresas. São Paulo,1991.

GOMES, Carlos. M. et al. Trabalho e conhecimento: dilemas na educação do trabalhador. São Paulo: Cortez, 1995.

GORZ, André. Adeus ao proletariado - Para além do Socialismo. Rio de Janeiro: Forense Universitária, 1987.

O declínio da relevância do trabalho e a ascensão de valores pós-econômicos. In: $\mathbf{O}$ socialismo futuro. n. 6, Instituto PENSAR/Fundação Sistema, Madrid/Salvador, 1993.

HABERMAS, Jürgen. Técnica e Ciência como Ideologia. Lisboa: Edições Setenta,1987.

HAUG, Wolfgang F. Crítica da estética da mercadoria. São Paulo: Unesp, 1997.

HARVEY, David. A condição pós-moderna. São Paulo: Loyola, 1993.

HELLER, Ágnes. Sociologia de la vida cotidiana. $3^{\text {a }}$ ed., Barcelona: Península, 1991. 
HOBSBAWM, Eric J. Mundos do trabalho; novos estudos sobre a história operária. Rio de Janeiro: Paz e Terra, 1987.

http://www.jaraguadosul.com.br/jaraguaemdados.htm. 02/12/2000.

http://www.jaraguadosul.com.br/histórico.htm. 02/12/2001, p. 4.

http://www.jaraguadosul.com.br/histórico.htm. 02/12/2001, p. 3-4.

http://www.jaraguadosul.com.br/doosie/index.htm. 02/02/2002.p. 7.

HUBERMAN, Leo. História da riqueza do homem. $21^{\text {a }}$ ed., Rio de Janeiro: Guanabara, 1986.

HUIZINGA, Johan. Homo ludens: o jogo como elemento da cultura. São Paulo: Editora Perspectiva, 1993.

IBGE- Instituto Brasileiro de Geografia e Estatística. Enciclopédia dos municípios brasileiros. Vol. XXXII, Revista dos municípios, 1959.

KRISIS, Grupo. Manifesto contra o trabalho. Cadernos Labur nº 2 (Laboratório de Geografia Urbana/Departamento. de Geografia/Universidade de São Paulo), 1999,29p.

KRISIS, In: http://www.consciencia.org/contemporanea/krisis.shtml

KUNZ, Elenor. Educação física: ensino \& mudanças. Ijuí: UNIJUÍ, 1991. . Transformação didático-pedagógica do esporte. Ijuí: UNIJUÍ, 1994.

LACERDA, Antônio C. de (Org.). (Des) emprego e globalização: avaliação e perspectivas. São Paulo: Educ, 1998.

LAFARGUE, Paul. O Direito à Preguiça. São Paulo: Kairós, 1983.

LEDESNA, Manuel P. O trabalho torna as pessoas livres? In: Revista Encontros com a Civilização Brasileira, n. 24, Rio de Janeiro: Civilização Brasileira, 1980.

LEFEBVRE, Henri. La vida cotidiana en el mundo moderno. Madrid: Alianza, 1984.

LOJKINE, Jean. A revolução informacional. São Paulo: Cortez, 1999.

LOPES, Sidnei M. O lazer e a cultura germânica em Jaraguá do Sul-SC. Universidade Estadual de Londrina. Monografia em Recreação, Lazer e Animação sócio-cultural. Londrina, 1998. 
LUCAS, Jaime. Entrevista: Alta Rotação.Revista Expressão. Florianópolis: Editora Expressão, ano 10, n⿳0 106, 2000.

MAGNANI, José G. C. Festa no pedaço cultura popular e lazer na cidade. São Paulo: Hucitec, 1998

MARINHO, Inezil P. Sistemas e métodos de educação física. $6^{a}$ ed., São Paulo: Papelivros, s/d. \& Cia, 1955.

Curso de fundamentos e técnica da recreação. Rio de Janeiro: Baptista de Souza Introdução ao estudo da filosofia da educação física e dos desportos. Brasília: Horizonte, 1984.

MARCELLINO, Nelson C. Lazer e educação. Campinas: Papirus, 1990.

O Lazer, sua especificidade e seu caráter interdisciplinar. In: Revista Brasileira de Ciências do Esporte, vol. 12 (1,2,3), Campinas: UNIJUI, 1992.

. Lazer e humanização. Campinas: Papirus, 1983.

. Estudos do lazer: uma introdução. Campinas: Autores Associados, 1996.

MARCUSE, Herbert. Eros e civilização: uma interpretação filosófica do pensamento de Freud. Rio de Janeiro: Zahar Editores, 1968 / 1981.

MARX, Karl. Posfácio da Segunda Edição. In: O Capital. Rio de Janeiro. Civilização, 1968. O Capital. Livro I, vol. 1, Bertrand Brasil, 1989.

MEDINA, João Paulo S. A Educação Física cuida do corpo... e mente. $5^{\mathrm{a}}$ ed. Campinas: Papirus Livraria e Editora, 1986.

1987.

O brasileiro e seu corpo: educação e política do corpo. Campinas, SP: Papirus,

MÉSZÁROS, István. A necessidade do controle social. São Paulo: Ensaio, 1987.

. Filosofia, ideologia e ciência social: ensaios de negação e afirmação. São Paulo: Ensaio, 1993.

MORETTI, Gilmar A. Subsídios para a história econômica de Jaraguá do Sul. Fundação Educacional de Santa Catarina - FESC, Escola Superior de Administração e Gerência ESAG e Instituto Técnico de Administração e Gerência - ITAG. Jaraguá do Sul, 1988. 
NAHAS, Markus V. Fundamentos da aptidão física relacionada à saúde. Florianópolis: UFSC, 1989.

OFFE, Claus. Trabalho como categoria fundamental? In: Trabalho e sociedade. Vol.1, A crise, Rio de Janeiro: Tempo Brasileiro, 1989.

OLIVEIRA, Paulo de S. Tempo Livre trabalho e lutas sociais. In: Revista Reflexão. Ano XI, n. 35, mai/ago. Campinas: Papirus, 1995.

PACHECO, Reinaldo T. B. O Lazer nas empresas: onde está o trabalhador? In: Revista Brasileira de Ciências do Esporte, vol. 12 (1,2,3), Campinas: UNIJUI, 1992.

PADILHA, Valquíria. Tempo livre e racionalidade econômica: um par imperfeito. Dissertação de Mestrado em Sociologia. Instituto de Filosofia e Ciências Humanas. Campinas: Unicamp, 1995.

PARKER, Stanley. A sociologia do lazer. Rio de Janeiro: Zahar, 1978.

PESQUISA DIEESE. Formação profissional: um novo espaço de negociação. São Paulo, n. 13, maio, 1998.

PMJS - Prefeitura Municipal de Jaraguá do Sul. Dados gerais. 1982.

Plano municipal de educação. Secretaria Municipal de Educação, 1993/97.

Turismo. programa. Secretaria da Indústria, Comércio e Turismo, 1993.

Jaraguá em dados. 1998.

QUADROS, Márcia. Encarando os Tigres. Revista Expressão. Florianópolis: Editora Expressão, ano 3, nº 36, setembro de 1993.

RAGO, Luiza M., MOREIRA Eduardo F. P. O que é taylorismo. $7^{\text {a }}$ ed., São Paulo: Brasiliense, 1993.

RAMOS, João P. Stress, ansiedade e nível de ativação. In: Manual do árbitro. Centro de estudos e formação desportiva. Secretaria de Estado do Desporto, Lisboa, 1998.

RÊGO, Walquiria L. e ANTUNES, Ricardo. (Orgs.). Lukács: um Galileu no século XX. São Paulo: Boitempo, 1996.

REQUIXA, Renato. Sugestões de diretrizes para uma política nacional de lazer. São Paulo: SESC, 1980.

RIESMAN, David. A multidão solitária. São Paulo: Perspectiva, 1995. 
RIFKIN, Jeremy. O fim dos empregos. O declínio inevitável dos níveis de empregos e a redução da força global de trabalho. São Paulo: Makron Books, 1995.

RODRIGUES, José Carlos. Tabu do Corpo. $2^{\text {a }}$ ed. Rio de Janeiro, RJ: Achiamé, 1980.

ROLIM, Liz C. Educação e lazer: a aprendizagem permanente. São Paulo: Ática, 1989.

SANTA CATARINA. Atlas de Santa Catarina. Gabinete de Planejamento e Coordenação Geral. Subchefia de Estatística, Geografia e Informática. Rio de Janeiro: Aerofoto Cruzeiro, 1986.

. Plano básico de desenvolvimento regional. Secretaria de Estado do Planejamento

e Fazenda. Diretoria de Desenvolvimento regional e municipal.

SANTIN, Silvino. Educação Física da alegria do lúdico à opressão do rendimento. Porto Alegre: Edições EST/ESEF- UFRGS, 1994.

SANTOS, Milton. Por uma outra globalização. Do pensamento único à consciência universal. São Paulo/Rio de Janeiro: Record, 2001.

SANTOS, Milton \& SILVEIRA, Maria L. O Brasil, território e sociedade no início do século XXI. Rio de Janeiro: Editora Record, 2001.

SCHAFF, Adam. A sociedade informática. São Paulo: Brasiliense, 1993.

SCHMOLINSKY, Grehardt. Atletismo. Lisboa: Editorial Estampa, 1982.

SCHÖRNER, Ancelmo. O arco-íris encoberto. Jaraguá do Sul, o trabalho e a história: operários, colonos-operários e faccionistas. Joinville, SC: Oficina Comunicações Ed.,2000.

SHUMPETER, J. A. Teoria do Desenvolvimento Econômico. São Paulo: Abril Cultural, 1982

SILVA, Ana M. Corpo, ciência e mercado: reflexões acerca da gestação de um novo arquétipo da felicidade. Campinas: Autores Associados: Florianópolis: Editora da UFSC, 2001.

SILVA, Emílio da. Jaraguá do Sul. II $^{\mathbf{0}}$ livro: um capítulo na povoação do Vale do Itapocu. Jaraguá do Sul, 1976.

SINGER, Paul. Desenvolvimento econômico e evolução urbana. São Paulo: EDUSP, 1968.

SOARES, Carmen L. Imagens da educação no corpo. Campinas: Autores Associados, 1998. 
SOUZA, José C. de. A questão da individualidade: a crítica do humano e do social na polêmica Stirner-Marx. Campinas: Unicamp, 1993.

STULZER, Aurélio Frei. O primeiro livro de Jaraguá. Niterói: Vozes, 1973.

TERNES, Apolinário. 36 Anos de História .... Joinville,SC. 1997.

THOMPSON, E.P.O tempo, a disciplina do trabalho e o capitalismo industrial. In: SILVA, Tomaz T. da. (Org.). Trabalho, Educação e Prática Social: por uma teoria da formação humana. Porto Alegre: Artes Médicas, 1991.

TONET, Ivo. Educação, cidadania e emancipação humana. Universidade Estadual Paulista. Tese de doutorado em Educação. Faculdade de Filosofia e Ciências, Marília, 2001.

VÁZQUEZ, Adolfo S. Filosofia da práxis. Rio de Janeiro: Paz e Terra, 1977.

YOZO, Ronaldo Y. K. 100 jogos para grupos: uma abordagem psicodramática para empresas, escolas e clínicas. São Paulo: Ágora, 1996.

ZARIFIAN, Philippe. Introdução. In: HIRATA, Helena (Org). Sobre o modelo japonês. São Paulo: Edusp, 1993.

ZILBOVICIUS, Mauro. O modelo Japonês no ocidente, Toyotismo, um novo padrão mundial de produção? São Paulo, 22 e 23 de Junho de 1993. Material de divulgação da CUT. 


\section{ANEXO 01 \\ ENTREVISTA COM O GERENTE dA FÁbriCA "X"(JARAGUÁ do SUl, SETEMbro dE 2000)}

01-Gostaria de saber os motivos reais que o levaram a ter o programa de ginástica aqui na fábrica.

Gerente- Primeiro porque eu gosto de esporte, em segundo por acreditar que traz melhorias até de longo prazo de postura para a vida. Depois, fazendo a ginástica eu mudo a rotina de trabalho do pessoal que está trabalhando aqui dentro. Então essa mudança de rotina, no dia a dia, provoca um bem estar.

02- Na literatura existe uma discussão sobre o modelo de organização do trabalho que se chama Toyotismo, tendo a ginástica como uma das formas de modificar a rotina de trabalho. Gostaria de saber se você tem informação sobre isso ou se faz parte do que você colocou antes?

Gerente - Tenho algum conhecimento disso por literatura, mas basicamente quando você lêe casa com o que você pensa fica mais fácil. Casa-se com o que eu acho em relação a ginástica, ao exercício e ao esporte. Apostei que daria certo. Pela experiência está dando certo. Deu para ver pelo exercício que fizemos aqui dentro que o pessoal está mais solto, embora ainda exista alguma resistência. Acredito que para a pesquisa o tempo ainda é pequeno, mas talvez possa pegar justamente por ser novo, algumas coisas que vão melhorar ao longo dos tempos. O espaço de tempo da implantação é curto, mas a gente já nota que o pessoal se empenha. No início tive um índice de rejeição pequena, hoje essas pessoas que rejeitavam estão aderindo mais ao programa.

03- Essa sua decisão, meio particular, de adotar e gostar da ginástica, se deve a sua prática nos exercícios corporais? Isso influencia os diretores da empresa?

Gerente: Já existia uma idéia, na ... acionamento que é uma das empresas do grupo, já tinha esse tipo de trabalho na ... motores que é a maior empresa do grupo, a fábrica ... foi a primeira aqui. Tínhamos alguns caso de LER, então, optou-se por colocar esse programa como uma maneira de reduzir, de uma ou outra pessoa, essas potencialidades de LER. Com a minha chegada aqui e essa abertura houve uma conclusão nesse sentido. Estimulo todos a participarem neste programa porque eu acho positivo, inclusive eu pratico. Embora esta prática não tenha provocado nenhuma alteração porque eu pratico exercício fora. Mas ela pré dispõe a pessoa para a jornada de trabalho como acontece aqui no horário das 15:00 horas. Nesse horário acontece um torpor e ao fazer o exercício melhora. A própria postura, você começa a fazer um ou outro alongamento que melhora. Ora você passa por aí e vê uma ou outra pessoa se alongando. Você começa a ver esse tipo de atitude, coisa que antes não acontecia. Não está acontecendo nenhum constrangimento. O pessoal da produção que passa muito tempo em pé de vez em quando está se alongando. Além disso criou uma outra coisa que é doze minutos de integração; essas brincadeiras onde um faz força contra o outro, as caminhadas em volta do lago, inclusive vamos trabalhar uma outra idéia em decorrência disso aqui. Essas caminhadas causam um relaxamento e uma integração muito boa e isso causa uma melhora na produção. Subprodutos que estão saindo desse trabalho que está iniciando.

04- Acho que também há uma melhora na qualidade do trabalho, as pessoas ficam mais inteiras, concentradas. Vocês podem ter menos problemas na qualidade do produto? 
Gerente: Acredito que isso a gente possa ver mais para frente. Ainda não consigo ver isso. Se eu tenho um mecanismo que me coloca mais ativo naquilo que estou fazendo pode ser que haja uma melhora nisso, ainda não tem nada que comprove isso.

05- Perguntamo-nos às vezes : qual é o lucro que a empresa vai ter?

Gerente: Não perdi produtividade, continuo fazendo o mesmo número de motores e até mais, os benefícios vão acontecer daqui para frente, a médio e longo prazo. A idéia é que estamos abertos para o novo desde que o novo mostre resultado; a gente acredita que esse programa mostre resultado em médio e longo prazo.

06- De certa forma o resultado hoje já existe porque não há alteração na produtividade e ao mesmo tempo a organização do trabalho interno fica mais interessante. As pessoas ficam mais sociáveis.

Gerente: Estou parando entre 09 e 12 minutos, duas vezes, coisa que antes poderia se suspeitar de perder a produção já que é uma parada de 20 a 25 minutos, todos os dias. São 208 funcionários e não houve redução, já é um indicador que não está comprometendo, traz benefícios.

07- E as resistências, como você explicaria?

Gerente: Aqui não procuro olhar as resistências, encontramos colaboradores que resistiram num primeiro momento, em relação até ao movimento (rebolar por exemplo), mas quando a pessoa vê que todo mundo está fazendo...entra no clima...não vou encostar nele porque é homem, homem com homem não é um troço muito legal e por aí vai, existe isso. Aos poucos as pessoas estão perdendo e estão entrando num clima da amizade e isto é um subproduto, que é de suma importância para nós, pois você estando numa equipe em que todo mundo é amigo, fica muito mais fácil trabalhar. Quer dizer, esta série de exercícios tem como objetivo o relaxamento, aumentar a resistência, mas como subproduto uma maior amizade, maior contato com o pessoal.

08- Há uma dinamização do afetivo, é isso que você está percebendo?

Gerente- Eu acredito que sim, já dá para ver pelo próprio caminhar do pessoal, pela própria conversa, no momento que está acontecendo a ginástica a gente percebe a integração desde o primeiro dia. Onde todo mundo era estranho, onde os grupos eram bastante separados, hoje você já vê um movimento de integração entre os grupos e isso é muito bom.

09- Isso é muito bom para o clima organizacional do trabalho, o expediente fica mais leve, mais solto e com menos tensão?

Gerente- Consegue formar melhor a equipe e diminui o estresse.

10- Essa questão do emocional, estou observando sempre a presença desses traços, mais até do que a questão do físico. Será que estou certa na minha avaliação?

Gerente: Essa presença do emocional sendo maior do que o físico fica muito evidente porque é mais rápida para acontecer a integração do que o físico. Não vai mudar o teu corpo num curto espaço de tempo, até porque esse trabalho com motores aqui é extremamente pesado, então o cara, fisicamente, já está bem dotado, correto? Então não vai ser este exercício que vai dotá-lo de capacidade física, pelo contrário, esse exercício vai fazer com que ele vá usar outras partes do corpo que ele no trabalho, normalmente não usa. É aquele negócio que eu já lhe falei: se o cara está de pé, puxa a perna para estender melhor, para alongar mais, levanta os braços, faz alguns movimentos para relaxar o ombro que ele usa bastante no dia a dia.

11- Então veja: as explicações dadas na literatura sobre a ginástica seguem a mesma linha colocada por você. Tais explicações são as alternativas entre a preparação para o trabalho ou para compensar os problemas corporais vindos do trabalho. Porém o que eu venho percebendo dos desdobramentos dessa prática nas pessoas é mais no sentido emocional, em seu interior; Deparo-me com a seguinte contradição: os fundamentos teóricos são fisiológicos 
mas o que ela atende, na realidade, na prática, são questões emocionais, afetivas, de relacionamento, de integração, enfim subjetivas.

Gerente: Eu não sei se você está certa, mas eu noto que desde o início que eu comecei a explanar aqui para ti, eu sempre disse que parece que houve uma maior integração, que houve subprodutos.

12- Todos na linha subjetiva.

Gerente- Todos na linha subjetiva, talvez porque seja mais rápido. A inércia é menor. A correção postural tem uma inércia maior, o físico, a estética.

13- Exige um tempo maior de trabalho?

Gerente- Exatamente. Em 20 minutos aqui, o grande foco, eu acho que é a subjetividade. Eu não estou afirmando, mas estou vendo assim uma rapidez muito grande desde o dia que se implantou até hoje, nós teríamos já oito meses (novembro de 2000) e o que a gente viu de real é isso.

14- Quem sabe num futuro até a própria (...) não inclua outros programas como teatro ou outras coisas que estimulem a criatividade. Nesse programa de ginástica não existe nada ruim?

Gerente: Não consegui ver coisas até agora que prejudicaram. Pode ser que daqui para frente... por enquanto, pelo contrário, só vi coisas que provocam a integração, se tiver pessoas predispostas a se integrarem. Lógico que se eu de repente começasse a olhar pelo lado de que isso não é legal, estou perdendo o meu tempo de produção, estou perdendo ativos, eu começo a resistir muito. Mas eu particularmente não consigo ver nenhum efeito negativo, pelo contrário está integrando e integrando muito.

15- Quanto a jornada de trabalho, você falou de tempo, são gastos quase 25 minutos numa média?

Gerente- A cada turno. Têm dias que dá nove, têm dias que dá doze, diariamente, cada sessão.

16- Vejamos: há uma alteração na jornada de trabalho internamente. No ritmo de trabalho, são quantas horas por semana que se trabalha aqui?

Gerente- São 8 horas e 48 minutos por dia.

17- Quantas horas por semana, 44 horas?

Gerente- 44 horas.

18-Há uma flexibilização do tempo internamente, uma modificação que diz respeito somente à questão do trabalho corporal. As alterações oriundas das novas tecnologias, da informatização;...a menina, lá em cima, falou que houve uma diminuição do número de empregados, dos postos de trabalho. Como é que fica nessa empresa a relação entre as tecnologias, postos de trabalho e tempo de trabalho?

Gerente: Mas quanto a ginástica eu não vejo, ela não (gaguejou), ela entra na jornada normal. A minha jornada continuou sendo oito horas e quarenta e oito minutos e dentro destas horas faço a minha produção e a ginástica, sem nenhum percalço.

19-Sem nenhum prejuízo financeiro para os operários?

Gerente- Continua a mesma coisa, nem para o operário, nem para a empresa. Pelo contrário, estou tendo pessoas mais dispostas; o fato de quebrar o ritmo deles, eu estou naquele ritmo aí parei dou uma relaxada, volto de novo e começo dali para frente. De repente eu não posso comprovar, mas pode ser até que eu começo com maior atenção. Por quê? Porque eu quebrei aquela rotina e estou naquele torpor, aí o cara quebrou o ritmo, vamos fazer outra coisa, o cara fica esperto de novo e vamos trabalhar. Eu não consegui perceber nada negativo. 
20- Então a jornada continua normal, sem prejuízo financeiro, nem para ele nem para a empresa, nenhuma das partes. Sobre a questão dos postos de trabalho, houve diminuição por quê? Isso é desdobramento das tecnologias?

Gerente: Eu tive, com certeza. Hoje, na minha fábrica aqui, eu tenho muito esforço físico para eu continuar trabalhando, eu tenho que aumentar minha produtividade, eu não vou, para aumentar minha produtividade, não vou colocar mais gente fazendo esforço para me dar mais problemas, não é por aí. Eu tenho que fazer o quê? Eu tenho que provocar o relaxamento desse pessoal, eu tenho que ajudar esse pessoal na melhor postura para fazer esse trabalho. Agora aquilo que sabidamente o homem não consegue fazer, não se adequa para fazer por causa do esforço, eu tenho que colocar equipamento que permita. Hoje eu tenho equipamentos que superam sobremaneira o esforço do homem, porém tem tarefas que eu não posso abrir mão do homem. A minha parte é muito peculiar nesse trabalho, tem alguns motores que só têm condição de fazer manualmente.

21- Há conversas sobre a ginástica com a direção geral (Presidente), com os outros diretores? Vocês analisam essa questão em reuniões?

Gerente: Com certeza que isso é passado, é conversado. Porque eu tenho como função de passar a informação de como está acontecendo aqui no meu setor e se eu concordo aqui na Fábrica "X" eu sei que já está estendendo para outras fábricas, já está tendo na II, na IV. O parecer que eu dei favorável é levado para frente e o diretor vai defender essa idéia também no que tem de positivo, pois não ficou ninguém com redução de produção. Vai levar esse parecer para frente. Eu tenho aqui, todo e qualquer problema que nós tenhamos, seja na compra de um equipamento, seja na parte de recursos humanos, temos que passar por comissões; essas comissões estudam e analisam o problema. Então, estou com alguns problemas de LER, que fazer para resolver? Nós vamos fazer o seguinte: vamos pegar essas pessoas e retirar do local? Não, nós vamos fazer alguns exercícios que possam compensar isso, vamos fazer algumas atividades que funcione preventivamente, enfim, é tratado onde? Então o fórum de discussão é essa comissão.

22- Toda fábrica possui essa comissão ? Ou é uma comissão geral?

Gerente- Não, é uma comissão acima das fábricas. É constituída por pessoas de diferentes áreas e áreas específicas daquele caso. Por exemplo, se eu vou comparar máquinas, eu vou para uma comissão que tem gerente de Holding, mas tem gerentes de outras áreas que vão opinar sobre o assunto e discutir. Se eu vou tratar de recursos humanos, de doenças que estão sendo geradas no trabalho, eu vou ter um grupo com o pessoal da área médica, com o pessoal dos recursos humanos e outra da fábrica, onde eu vou discutir: olha, mas a minha fábrica eu estou fazendo a ginástica, quem sabe tu experimenta isso ao invés de simplesmente encostar esse cara num canto. Boa idéia, mas eu não posso fazer esse exercício assim assado, beleza, mas nós podemos fazer outro. E por aí vai se trocando as idéias e busca-se um consenso. Nós temos várias comissões.

23- Essas comissões se responsabilizam no encaminhamento dos problemas e encontram as soluções adequadas?. Essa empresa é realmente muito organizada e eles pagam bem?

Gerente- Depende de qual é a sua expectativa. Eu estou satisfeito. A nossa rotatividade é baixa.

24- Entrou aqui e ninguém quer mais sair?

Gerente- Eu estou com 20 anos de empresa, tem pessoal aqui dentro que já tem 25, 30. Isso é normal. Cada crachá dos colaboradores tem um emblema que significa dez, quinze anos, comece a observar que você vai ver.

25- Esta estabilidade também cria uma aproximação com a empresa, cria vínculos, não é?

Gerente- Cria. 
26- Pois é, com essas mudanças, a flexibilização e o fim do emprego pleno, aqui ainda não está existindo isso? Aqui existe esse vínculo?

Gerente- É, nos EUA vale mais quem já rodou mais. Já na Europa vale mais quem roda menos. Por que? Porque isso cria um vínculo, aqui, nesta fábrica " $X$ ", podemos dizer que é uma empresa nova, que ela está na fase de transição de uma geração para outra. Ela está na adolescência, ela tem 39 anos. Ainda está valendo o que foi um ensinamento do início de sua história e que faz parte da cultura da (...), essa longa permanência dentro da empresa. Nós aqui estamos acostumados e estranhamos quando a coisa é diferente, uma pessoa entrar e sair. Nosso colaborador aqui tem uma vida bem mais longa.

27- A empresa investe e quer que a pessoa fique dando o seu retorno? A minha curiosidade é que a (...) é a $2^{\mathrm{a}}$ maior produtora de motores?

Gerente- $O$ grande desafio é se tornar a $n^{\circ} 01$ na fabricação de motores até 2007. Hoje ela é a $5^{a}$ do mundo.

28- Podemos afirmar que é um modelo que está dando certo?

Gerente- Essa filosofia da (...), eu acho que é extremamente válida, por que? Porque, nós apostamos no colaborador quando ele tem 14 anos e aí entra na nossa escolinha. Lá na escolinha também nós fazemos ginástica. Esse pessoal já vai trazer isso. Aí ele fica lá até os dezessete, dezoito anos. Sai para vir para a fábrica. Então nós estamos investindo. Esse pessoal já começa perceber essa cultura lá dentro da escola. Quem são os professores da escola? São funcionários da empresa, que de uma forma ou de outra foram para escolinha ensinar isso; isso vem sendo absorvido por eles.

29- A formação dos colaboradores é somente por essa escola?

Gerente- Não, alguns casos sim. Em 1971, quando iniciou a escolinha era praticamente toda a formação de lá. Hoje, não, nós já temos várias escolas, várias fontes de abastecimento de mão de obra, mas antigamente quando Jaraguá estava crescendo e não era tão aberta a formação era só da escola. Hoje não, vem gente de vários lugares. Vem do RS, vem do PR, vem de SP. Estão confluindo para cá procurando possibilidades e condições. Quando chega aqui encontra um celeiro forte, por que? Porque a (...) dá oportunidade de criar, de participar do crescimento e isso tudo aliado a essas novas tendências. Então tu vai indo e vai se emocionando e vai continuando.

30- Pois é, com a globalização e a exigência de se entrar no mercado mundial, como a (...) está encontrando as alternativas ou qual é a forma que ela está entrando nesse mercado?

Gerente- Vou te mostrar uma coisa. Tem essa distribuição dos produtos dessa fábrica, 30\% fica no mercado interno, $70 \%$ vai para o mundo, nessa distribuição que você vê aqui. A(...) hoje está espalhada mundialmente, então nós acabamos de comparar uma fábrica no México. Comparamos duas fábricas na Argentina. Temos escritórios nos EUA, México, Canadá, Europa, África, Austrália, Nova Zelândia.

32- No mundo?

Gerente- No mundo. Nos EUA quatro postos. Buenos Aires, Europa, Bélgica, Inglaterra, Alemanha, Espanha, Japão, Escandinávia. Sendo que no México nós temos além do escritório, uma fábrica, a antiga BB agora fabrica motores. França, embora estejamos em Jaraguá do Sul, mas a nossa missão é grande.

33- Isso se torna curioso. Uma empresa localizada no interior e com tanto poder de venda de um produto que é realmente aceito. É um produto diferenciado? O que existe de diferente?

Gerente- $O$ diferencial, eu acho que é capacidade de trabalhar, acreditar no ser humano, que é a solução. Porque se não, não estaríamos do tamanho que estamos. E buscar investir. Dinheiro a gente busca a qualquer momento em qualquer banco, agora se tu investe nas pessoas, essas é que vão te gerar benefícios, é o que a gente está fazendo. E a ginástica vem justamente ao encontro disso, ou seja, vem valorizar o ser humano. O corpo, a integração.

34- Qual a sua conclusão? 
Gerente- Eu acho que a ginástica ajuda, integra. Tem subprodutos que até mesmo não foram externados aqui Mas que irão aparecer a médio e a longo prazo.

35-Quais os que você apontaria nesse momento?

Gerente- Um é o da integração, outro é o da amizade, cada um começa a conhecer melhor o seu companheiro, trabalha junto, diminui consideravelmente a resistência. Veja bem, ninguém pode afirmar assim que não há desgaste emocional no dia a dia, há. Agora quando tu toca numa pessoa, tu começa a relaxar. Isso a ginástica propicia. Tem muitos exercícios aí que exige o toque, mas não é simplesmente tocar no corpo do outro, mas é entregar um pouquinho de ti para o outro. E vice versa, e isso ajuda muito e isso integra, faz amizades.

36- Vai alterando mesmo as relações internas de trabalho?

Gerente- Vai, com certeza.

37- É, eu estou observando também que as pessoas com quem converso aqui são muito entusiasmadas, empolgadas com a empresa, isso é importante também como um elemento da organização do trabalho? Sente-se que há um clima desse quando entramos aqui, é até contagiante, saio até animada.

Gerente- Que bom que seja assim. Eu gosto. Agora se o cara que vem de fora, se a pessoa que vem de fora percebe isso é sinal que existe. Porque quem vem de fora vem sem nenhum vício e olha, e sente isso, é sinal que está no ar. É, a energia está no ar.

Continuação da entrevista fora do escritório. Comentários do gerente mostrando a fábrica: $a$ filosofia da (...) é do trabalho em equipe. Tudo sempre foi decidido em equipe. Quando chegou o CCQ já tinha o terreno fértil. O CCQ são grupos, círculos de controle de qualidade, grupos de pessoas que visam melhorias dentro da fábrica. Tem que se reunir de tempos em tempos e sugerir uma idéia e implantar. Já estávamos acostumados a trabalhar em equipe. Agora chegou a ginástica nesse solo, a semente já está lá. Então a coisa tem tudo para funcionar. Tem tudo para dar certo. Com isso só tende a crescer

38- Vocês têm abertura? Isto não é uma coisa nova?

Gerente- Não, já existia, é mais um método, mais uma coisa.

39- Essas novidades sobre a organização do trabalho, a participação do trabalhador nas decisões, etc como estão acontecendo aqui na (...)?

Gerente- Eu não lembro bem o ano, mas um tempo bem atrás, um dos seus fundadores .... foi para a Europa trabalhar numa empresa de motores. Conheceu um monte de coisas e veio para cá. Aí em outro momento um outro saiu e foi para São Paulo, trabalhar lá também e veio para cá e aplicou aqui também.

40- É outra mentalidade?

Gerente- É, é outra mentalidade.

41- Não é um modelo de fora do Brasil?

Gerente- Não, vai nascendo com essa peculiaridade. Porque esse jeitinho do cara sair daqui, ir lá fora procurar conhecer e trabalhar para captar o conhecimento é coisa de brasileiro. Se você olhar, a vida funciona em ciclos, é um ascenóide, para mim que sou engenheiro é um ascenóide. De 07 anos de vacas magras há 07 anos de vacas gordas e assim vai. Grosseiramente é isso aí que acontece. No período que dá crise o que é que se faz, comparase máquinas, prepara pessoal, quando está subindo todo mundo agora vou comparar máquina; não, a máquina já está aqui e o pessoal já está preparado, agora é só subir a ladeira. Quando estiver lá em cima os outros estão então recém começando e eu estou ganhando o mercado, então a (...) cresceu muito com isso e com essa mentalidade. Quando está em baixa é a hora de investir, quando está subindo é a hora de só ganhar. É o que está acontecendo agora.

42- É, a crise está grande e a (...) não apresenta nenhum sintoma disso?

Gerente- Está comprando fábricas, está empregando gente, está produzindo motores. Esse ano vai ser para estourar a boca do balão. 
43- A sociedade aqui é fechada, não é?

Gerente- É, a sociedade germânica é fechada, depois que você conseguir entrar você consegue se relacionar, mas eles são extremamente fechados no primeiro contato, depois fica normal. Então em 1981 era fechado, eu cheguei aqui do Rio em 81, naquela época era comum ir num médico e ver uma senhora lá com a neta porque ela não falava português, só falava alemão. Então ao precisar interagir com o médico precisa de intérprete, ou a filha ou a neta.

44- Isso é recente?

Gerente- É recente, 20 anos. Está mudando, muita gente vindo de fora, a cultura brasileira está entrando. Então, agora pode estar havendo uma briga onde vai sobreviver aquele que tiver maior número. Lógico que o pessoal daqui vai ter um ganho porque tem uma maior quantidade só que Jaraguá se abriu com a globalização e dá entrada de pessoas com novas culturas. Como não havia mão de obra especializada, essa mão de obra veio de fora. Mão de obra especializada é sinônimo de formador de opinião. Então isso gera essa mudança: a Schützenfest iniciou com bandas típicas alemã. Hoje já começa a ter o toque, já começa a ter alguma coisa da música popular brasileira. Então essas coisa, isso data de doze anos. Então está havendo essa troca.

45- Você falou que o carnaval aqui não acontece, as festas se concentram em outubro e são festas regionais. Carnaval que é uma festa tipicamente brasileira. Você falou que aqui até se trabalha e não há alteração no cotidiano.

Gerente- Eu não sei se foi no ano passado, estava previsto um desfile de um grupo de um bairro que ia ter uma escola, um negócio desse tipo assim, ia desfilar e aí choveu. Foi cancelado, não houve transferência para outro dia, foi cancelado. Não faz parte da cultura.

46- Aqui é a festa de ...

Gerente-Aqui é a Schützenfest, em Blumenau é a Oktoberfest, em Joinville a Fenachope, temos várias festas em outubro em Santa Catarina. Vem grande quantidade de pessoal de fora, principalmente para a Oktoberfest em Blumenau. Acabam vindo para a Fenarreco, a Marejada ou para o Faneco. Em Jaraguá é esquecido, por quê? Porque Jaraguá procura fazer uma coisa ainda mais voltada para a cultura alemã, que é a Schützenfest. Então ela não divulga nacionalmente, só localmente. Das festas todas é a que mais guarda as tradições da cultura germânica.

47-E as pessoas se preparam durante o ano para essas festas?

Gerente- Há uma organização toda. Traz coisas da Alemanha.

48-É a festa de quê?

Gerente- É a festa do tiro.

49-É um esporte caro?

Gerente- Os que se dedicam a isso tem que gastar. Tem uns estandes lá com bastante tecnologia, tem um monte de coisa lá que eu não conheço bem. No dia que eu fui lá e atirei eles estão até hoje procurando a bala.

E o Lazer o que fazem?

Gerente- Eu jogo futebol, duas vezes por semana eu jogo, é certo.

Essas coisas assim eruditas, teatro, cinema.

Gerente- Cinema aqui tem. O teatro tem grupo aqui e estão construindo um muito bonito, muito amplo. Quando isso estiver funcionando a todo vapor vai trazer muita gente de fora. Já estão vindo para cá alguns grupos de pintura, teatro, mas ainda não tem um local próprio e com a SCAR este local já está prestes a acontecer.

50- E os trabalhadores?

Gerente-Temos as associações recreativas, jogos, campeonatos.

Obrigada! 


\section{ANEXO 02 \\ ENTREVISTA COM O COORDENADOR ESTADUAL DO PROGRAMA GINÁSTICA NA EMPRESA DO SESI NO ESTADO DE SANTA CATARINA ( FLORIANÓPOLIS, JULHO DE 2000)}

01- Por favor, fale como vocês levantam os dados sobre as impressões que os trabalhadores têm do programa de ginástica na empresa:

Resposta: Quando iniciamos o programa de ginástica na empresa nos deparamos com dificuldades em relação aos dados para a empresa nos passar dados que fossem pertinentes à possibilidade de avaliarmos o programa. A partir disso começamos a utilizar um instrumento validade pelo SESI da Bahia, que é uma pesquisa que a gente aplica com os trabalhadores antes de iniciar o programa de ginástica na empresa. Esta pesquisa contém levantamento de dados em relação onde o trabalhador está inserido na empresa, como ele termina o trabalho, se termina bem ou se sai estressado, se está dormindo bem, como acorda, que tipo de dores tem sentido por regiões do corpo, como são os hábitos deles em relação à atividade física, como são os hábitos com relação à alimentação, ao fumo, ao consumo de álcool e depois se ele gostaria ou não de participar de uma intervenção como essa.

02- Vocês não perguntam se eles usam outras drogas. É constrangedor?

Resposta- Sim, até porque não nos interessa muito, porque seria de nosso interesse se a gente tivesse uma intervenção que pudesse contribuir de alguma forma, mas como isso também é problemático... Porque quando essas pessoas nos procuram porque tem esse problema nós até temos o serviço social e ele trabalha com avaliação e manejo com usuários de álcool e outras drogas, mas é problemático. A gente pergunta se eles têm interesse em participar de uma intervenção do programa de ginástica na empresa, uma média de $93 \%$ de pessoas que passam por essas sensibilizações tem interesse.

03- Então a ginástica é feita por livre e espontânea vontade?

Resposta - Sim. Até é interessante que se conte. Um colaborador que nós tínhamos aqui da área de lazer, já é falecido, nos dizia que em Brusque, em 1993, tínhamos um programa de ginástica na empresa que era obrigatório. Era numa confecção de nível médio, só que naquela região de Brusque tinham muitos evangélicos e essa religião não permite que eles façam atividades físicas, principalmente as mulheres. Então aconteceu muitos casos em que alguns preferiam pedir demissão a ter que ir contra a religião, ter que fazer atividades físicas, isso foi um marco histórico dentro do programa de ginástica no SESI. Até aquele momento nós fazíamos um tipo de programa e nós aceitávamos até que o empresário dissesse: quero que esse programa seja obrigatório. Hoje, quando o empresário diz isso, a gente fala o seguinte, a gente tenta explicar porque não pode ser obrigatório, mas se ele insistir, nós mandamos procurar uma outra empresa que faça este serviço. É nosso marco que a gente faça dessa forma.

04- Quer dizer que vocês avaliaram e mudaram a forma de conduzir o programa?

Resposta - Exatamente.

05- A característica de não-obrigatoriedade é fundamental para o funcionamento deste programa? As influências regionais, culturais das pessoas estavam influenciando a aceitação do programa?

Resposta- É do próprio desenvolvimento do programa. Porque quando você tem uma obrigatoriedade de fazer alguma coisa você tem que imaginar que basta ter um que esteja fazendo obrigado que isto pode disseminar para os outros, num processo de motivação, um 
processo nocivo e que pode acabar interferindo e acabar o programa. Então é interessante essa pesquisa que se faz, ela é refeita 06 meses depois e a gente avalia os dados a partir disso. Infelizmente esses dados para a empresa não são tão pertinentes porque é uma perspectiva só do trabalhador. Porque muitas vezes a empresa quer saber, algumas empresas que tem sua atividade social um pouco mais adiantada, aguçada até se preocupam em honrar com o que o trabalhador pensa, porém o que está acontecendo é que a maioria das empresas quer saber se o investimento para pagar um tipo de ginástica laboral está de acordo com os resultados alcançados.

06- Se tem algum retorno, como eles vêem isso?

Resposta: Pode ser visto de algumas formas...

07- O retorno do investimento, não é?

Resposta: Pode ser feito via aumento da produtividade ou manutenção da produtividade. Por que manutenção da produtividade? Porque se a gente perde doze minutos por dia e mantêm a mesma produção significa que houve um aumento da produção nos outros minutos do dia. Às vezes conseguem perceber um aumento da produção também, numa escala que varia geralmente entre $2 \%$ e $3,5 \%$.

08-É significativo para a empresa?

Resposta - Muito significativo, mas não temos dados precisos em relação a isso, por que a gente ainda tem uma dificuldade de medir isso, muitas vezes a empresa não nos fornece dados que a gente possa medir isso. A gente ainda está num processo de comprometimento com a empresa, ganhando algum espaço para que a empresa comece a estar sensível para ajudar nessa forma de medir, não é fácil. Outra forma é com diminuição de procuras ao ambulatório. Algumas empresas que tem bem organizado o serviço ambulatorial conseguem medir a quantidade de pessoas que vão ao ambulatório. Porque as doenças ocupacionais muitas vezes em determinadas regiões do estado de SC, que é bem heterogênea, principalmente no que diz respeito ao clima, temos algumas épocas do ano, por exemplo: em Mafra é uma região muito fria, uma cidade que menos faz sol no país, no planalto norte de $S C$, temos entre maio e agosto um surto de gripe muito grande. Então aumenta consideravelmente a procura ao ambulatório, só que é uma procura que não está relacionada com o programa de ginástica, nós temos que ter sensibilidade para não medir isso como fator preponderante, então por isso que a gente dá mais atenção a procura ao ambulatório por doenças ocupacionais, muitas vezes quando o ambulatório tem um nível de critério de seleção grande a gente consegue perceber também que a procura por cefaléia diminui e principalmente as que acontecem no primeiro momento de turno de trabalho, principalmente porque tem uma exigência física muito grande no início do trabalho. Então nós fizemos uma ginástica preparatória e a gente percebeu que existe uma diminuição, há casos esporádicos de cefaléia no início do trabalho. Outra forma de medir é a própria questão das faltas, a diminuição das faltas, o absenteísmo. $O$ índice das faltas também é muito interessante. Para o trabalhador, ele acredita que participar de um programa de ginástica é muito importante, principalmente aqueles que foram facilitadores do programas, aqueles que executam a séries para seus colegas, em virtude disso eles até sugeriram, em geral, que fosse feito um diploma pelo SESI ao facilitador, porque eles acham que isso pode dar um diferencial de empregabilidade, caso eles venham estar fora, mais uma capacitação, exatamente como se fosse mais um crédito para recolocação no mercado, no currículo, em especial os trabalhadores da Petrobrás.

09- Sobre o programa e a relação com os dados levantados, vocês modificam, alteram o programa a partir da avaliação destes dados. Há uma alteração ou não?

Resposta: Não, efetivamente na nossa mente quando se faz um diagnóstico, nós temos um software que nos permite, a depender do diagnóstico que se faz; o diagnóstico levanta 20 
fatores de risco: receptividade, compressão mecânica, força submáxima, posturas inadequadas na região escapular, região lombar, postura sentada, o próprio gênero e outros. Ele levanta alguns fatores que são considerados fatores de risco e a partir destes listam uma média de 100 a 50 exercícios que possam influenciar positivamente naqueles fatores.

10- Isso é um programa já pronto, elaborado?

Resposta: Exatamente, no caso, quando levantamos o diagnóstico nós temos um problema muito sério também de relacionamento, temos que entrar com uma intervenção também fora os 8 minutos de ginástica para contribuir de forma positiva para melhoria do relacionamento.

11-Questões subjetivas também são avaliadas?

Resposta- Também são avaliadas. Como a questão de subjetividade não é muito palpável, depende muito da qualidade do professor que está lá na ponta, alguns fecham os olhos para isso, mas outros que fazem o melhor trabalho, no caso da Coordenadora que está lá na ... ela está preocupada com isso, acabam se dando conta que algumas questões precisam ser trabalhadas, principalmente para o bom desempenho do programa.

12-Essas questões vocês acrescentam ao software...

Resposta- Nós acrescentamos a execução do programa naquela empresa.

13- Vocês recriam um pouco...de acordo com a solicitação da realidade...

Resposta- Exatamente, porque o software é um padrão, mas tem um campo para observações e para atividades paralelas, e é nesse campo que nós vamos colocar que tipo de atividades nós podemos fazer.

14- Quem define essas atividades?

Resposta - A equipe técnica do CAT, porque quando sempre que transcende um pouco a figura do profissional de educação física, nós temos um fisioterapeuta, assistente social, enfermeira do trabalho, médico do trabalho aqui, um médico do trabalho em Itajaí, um técnico de segurança para poder nos dá um suporte, um pedagogo, para poder nos dar um suporte melhor. Geralmente o profissional mais perto do professor de educação física na execução é a assistente social.

15- Ainda sobre a questão da avaliação. Você falou que tinha observado, quando era coordenador, uma alteração não tanto física, mas também de clima organizacional do trabalho internamente. Gostaria que você falasse sobre isso.

Resposta.: Talvez isso tenha sido levantado por uma dificuldade que a gente tenha tido em medir alguns dados, tendo nos despertado para ficar mais sensivel, para tentar medir outras coisas, a única garantia hoje em dia que nós temos de um programa melhor é o clima organizacional da empresa, porque esse break(parada) que a gente faz da jornada de trabalho, principalmente porque a grande maioria das empresas hoje trabalham com produção individual também. Por produção individual tem prêmio por produtividade, as pessoas esquecem que tem um vizinho, de problemas e que a gente também tem problemas $e$ passam a trabalhar também como máquinas. É uma exigência até da própria empresa, é uma produção mínima que tens que atingir e eu sou defendo que se limitar, acho que o prêmio por produtividade, ...limitar muito próximo de uma produção média.

16- Esse prêmio sempre houve na empresa?

Resposta: Muitas vezes e continua ainda, sim quem produz mais ganha um prêmio...quem produz mais não é que ganhe um prêmio, mas cada pessoa que produzir mais do que a meta começa a agregar no seu salário aquela produção. Só que às vezes é tão irrisório que as pessoas não se dão conta, às vezes trabalham uma hora ou 40 minutos a mais, ou trabalham como loucos durante sua jornada de trabalho para ganhar $R \$ 1,20$ ou $R \$ 1,30$ até $R \$ 1,50$ para no fim do mês Ter $R \$ 30,00$ de diferença. Talvez até faça alguma diferença no nível 
cultural que eles tem, mas a gente tem que perceber até que ponto essa máquina humana vai suportar essa pressão. Então esse prêmio de produtividade que as empresas chamam, acaba por interferir um pouco no próprio bom relacionamento que as pessoas têm.

17-Cria uma competição?

Resposta- Exatamente, cria uma competição individual, principalmente quando se têm células de trabalho e não uma linha de produção.

18-Lá na (...) é por células?

Resposta- Algumas unidades são por célula, outras por linhas de produção, onde cada uma monta um pedaço. Por exemplo, numa tecelagem onde é a costura, por exemplo, é por produção, é por quantidade de camisa, ou de calças que se faz num dia, e a pessoa que fizer a mais vai ganhar $R \$ 0,10$ por calça que fizer. As pessoas acabam não perdendo tempo para conversar, para ir ao banheiro, e não gostam de ir a ginástica, porque acham que vão perder 12 minutos ou 8 minutos, isso é uma questão problemática. Então quando conseguimos sensibilizar os trabalhadores de que aquele break (parada) é importante, 8, 10, 12 minutos é importante, então é aquele momento onde ninguém pensa em produção, onde as pessoas possam se tratar de novo como pessoas, como colegas. Muitas vezes eu vi caso desse em Blumenau de que numa célula de produção, onde se faz camisetas, a pessoa que trabalhava na frente dele já há sete meses sequer sabia o nome, nunca tinham conversado. Depois que se começou a ginástica, se percebeu que as pessoas tinham ali momentos onde a gente se toca, dá as mãos, bate palmas, conversa e ninguém quer saber da produção. Se desliga, esse é o ponto que nós acreditamos que seja imediato e garantido com nosso programa de ginástica na empresa, é a melhoria do clima organizacional, porque a gente consegue convencer de forma positiva os trabalhadores que naqueles minutos é para eles, deles.

19- Isso você (convence)consegue através da prática da palestra de sensibilização, vocês colocam para eles que essa possibilidade existe. Executando aquele programa eles vão se beneficiar e eles ficam com essa opinião ?

Resposta- Imagina assim, na verdade você está tendo 12 minutos que a empresa está pagando igual, não tem desconto no seu salário. E as nossas atividades paralelas como eu tinha falado antes estão começando a trabalhar com caminhadas. A empresa de sua pesquisa já faz caminhadas, hoje, um dia por semana ao invés de fazer os exercícios compensatórios eles saem e fazem a caminhada em volta do lago, isso dá 10 minutos e as pessoas adoram. Você já imaginou, a empresa está pagando para você 10 minutos, para caminhar no sol, por exemplo, aquilo realmente passa a ser uma questão muito importante porque uma fábrica ou galpão muito escuro, fechado. Então você tem 10 minutos, que a empresa paga para você ir lá e dar uma volta no sol respirando e pode ficar conversando com as pessoas, colocando as fofocas em dia, enfim relaxa?

20-Diminui a tensão?

Resposta- Exatamente. Nós temos alguns depoimentos de gerentes da empresa que depois da ginástica o rendimento passa a ser muito semelhante como no início da jornada, quando a gente faz a ginástica compensatória no meio da jornada. O nível não chega a tanto como se estivesse iniciando, mas muito semelhante. A gente acredita que no diagnóstico a gente consegue que algumas empresas que nos liberam, porque as empresas limitam muito de nos liberar número de acidentes de trabalho.

21- Por que?

Resposta-Porque cada acidente de trabalho eles têm que preencher, por lei, uma CAT, que é um Comunicado de Assistência do Trabalho, tem que ir pro INSS, isso geralmente é multado. Então as empresas sempre que podem procuram evitar emitir o CAT. As empresas também têm restrição de nos entregar a quantidade de acidentes de trabalho. Mas a gente procura 
levantar em que momento do dia, do turno de trabalho acontece geralmente o acidente, tem alguns estudos, acadêmicos. Ainda com relação ao momento de acidente de trabalho, geralmente está relacionado depois das refeições, principalmente as refeições maiores, até uma questão fisiológica. É nesse momento a partir do diagnóstico que a gente precisa entrar com a ginástica justamente para aumentar a ativação da atenção de todo o corpo e a gente entra com a ginástica nesse momento e consegue realmente diminuir o acidente de trabalho dentro dessa perspectiva.

22- Você entra com a ginástica depois do almoço?

Resposta: Quando se diz depois do almoço não é efetivamente depois, porque quando a gente vem de uma refeição a gente não está no local de trabalho, a gente ainda vem com um nível de ativação geralmente 30/35/40 minutos depois que a gente retorna ao posto é que a gente começa a diminuir a tensão. Então a ginástica, por exemplo, o ideal, porque o ponto crítico está entre 2 e 3 horas da tarde, onde entra a ginástica, 14:30, 14:45, 14:15, justamente porque é o momento que o pique de ativação diminui mesmo. Nessas empresas, os engenheiros de trabalho e até o pessoal da produção quando tem isso bem regular, eles conseguem perceber onde é que a produção diminui, onde a produção é alta, onde é baixa, por hora, porque eles produzem por hora, então, dentro dessa perspectiva que as empresas nos passa a gente consegue detectar certinho qual o momento ideal para entrar com a intervenção da ginástica, não que ela não tivesse esse benefício, mas a gente pode agregar mais um benefício. Até porque aquele momento estava meio morto, aproveita e já faz um benefício maior. Então o gerente nos explicou que depois da ginástica o rendimento volta a ser muito bom. Acaba tendo um rendimento bom e de atenção até o fim da jornada, do turno.

23- Também há um trabalho na atenção, quer dizer, melhora a concentração?

Resposta: Sim, porque aquela parada é muito interessante, como se desligasse da produção, se desligasse daquela atividade automatizada que está fazendo todo dia.

24- Isso quando é na linha?

Resposta- Exatamente quando tem linha ou mesmo numa célula de produção cada um fazendo sua peça inteira, isso ajuda muito.

25- Sobre o programa, ele é um programa do SESI, porém vocês aqui estão adaptando. E o padrão, o modelo pronto que você colocou antes, como é que fica? Você sabe se existe alguma influência do modelo japonês? Qual a origem do programa?

Resposta: Na verdade, em virtude daquilo que é feito hoje, no contexto histórico que se está vivendo, quem programou, projetou esse programa dentro dessa perspectiva que se vive hoje, foi o SESI de Minas Gerais. Esse programa foi certificado lá com a ISO 9002. O departamento nacional comprou essa idéia e passou para os outros 26 estados que tem o SESI, uns fazem com mais ênfase outros com menos ênfase, $M G, S C, P R, R S, B A$, são os que dão realmente ênfase. Nós, em $S C$, damos ênfase porque é uma maneira de atender a empresa e a receita, o retorno financeiro é interessante. Com relação ao que me perguntaste, o que posso dizer é o seguinte: pelo ano que isso foi projetado, com certeza isso tem muito da perspectiva japonesa, tem influência.

26- A influência no caso de como eles acrescentaram lá, essas formas de operar, de organizar o expediente do trabalho.

Resposta: Tem uma questão de re-engenharia que foi uma coisa que os americanos usaram muito também. Mas tem um pouco de questão do brasileiro mesmo, tem uma avaliação na metade da década de 70 no RJ se usou muito isso, ainda com uma perspectiva muito forte do Japão. Tem alguma coisa de escola polonesa, a gente cita isso que em 1925 já pensavam sobre isso, já executavam. Então acho que é uma miscigenação daquilo que cada um tinha de bom. Uma questão que acho que é grande diferencial do nosso programa de ginástica na empresa para com todos os outros programas é que o nosso programa tem uma preocupação 
primordial, que é o bem estar do trabalhador, a gente não está ali para corrigir postura, efetivamente, a gente acha até que isso seja secundário, para diminuir a pressão dos movimentos repetitivos, a gente acha que o programa de ginástica na empresa tem a função principal de incutir em cada indivíduo a obtenção de um estilo de vida mais ativo.

27- Há um desdobramento para fora do trabalho?

Resposta: Certo, para ele e para família.

28- Quer dizer, vocês querem influenciar mesmo na formação deles também.

Resposta: Por que digo isso? Porque em 1999 tivemos uma pesquisa com 4.500 trabalhadores da indústria e a pesquisa foi coordenada pelo prof. Nahas e chegamos a conclusão que o maior fator de prevalência de risco para os industriários de Santa Catarina é o sedentarismo, mais do que o tabagismo, mais do que o estresse. O sedentarismo, passamos a focar nosso programa com um programa educativo em que as pessoas pudessem ter naqueles 8 minutos ou 16 minutos, quando fazem 2 vezes por dia despertarem para um estilo de vida mais ativo.

29-É uma das questões que pretendo enfatizar na minha pesquisa. Esse programa de certa forma influencia na vida fora do trabalho?

Resposta: A nossa intenção é essa...

30- Ou seja, despertar de alguma forma para uma prática...

Resposta: Porque a partir disso nós temos 4 intervenções. Que é uma intervenção sobre estilo de vida e hábitos de lazer. Se faz geralmente com 80/90 dias de implantação, numa pesquisa muito simples, numa pesquisa que veio adaptada dos EUA, 140 dias de implantação que é sobre o gerenciamento de estresse.

31- E esse estresse... a minha dúvida é se sempre houve e nunca foi evidenciado ou se ultimamente aumentou essa condição estressante. Quais seriam os elementos que estariam provocando essa maior intensidade?

Resposta: É uma perspectiva minha pelo que tenho lido, acho que o estresse sempre houve, se a gente for olhar. 200, 300 anos atrás o indivíduo trabalhava 14 horas por dia, em condições subumanas em relação ao que se vive hoje, entretanto, acho que o que se avançou muito foi a questão legal de preocupação com o ser humano, porque hoje os passivos trabalhistas são enormes.

32- O que é isso, passivos trabalhistas?

Resposta: São ações que a empresa têm contra ela de trabalhadores na justiça. Por exemplo, isso não é um fato oficial, mas no meio que a gente vive, dentro das empresas, diz-se que a empresa Sul Fabril, que é uma empresa muito grande em Blumenau, teve problemas seríssimos e quase faliu por causa de passivos trabalhistas. Aí eu acho que a LER, DORT, estresse passaram a ser armas que o trabalhador têm para se defender. Conheço caso que eu $v i$, de pessoas que estão afastadas do seu trabalho por problemas de LER, até uma nomenclatura que não se usa de 97, porque o INSS não considera mais LER (Lesões por Esforços Repetitivos) e sim DORT - Distúrbios Ósteo-musculares Relacionados ao Trabalho, por ser distúrbios.

33- Essa mudança de nome não é para descaracterizar um problema que é conseqüência do trabalho? Eles não estariam transferindo o problema para o indivíduo e assim desviando do trabalho? LER, sendo lesões por esforços repetitivos e quando se muda para DORT distúrbios Ósteo-musculares, o indivíduo assume um problema orgânico e descaracteriza o tipo de trabalho muito repetitivo e extenuante.

Resposta: Tem uma pesquisa que durante 20 anos, estudou a LER e somente 13\% são realmente por movimentos repetitivos, 60 e alguma coisa são por problemas psicossomáticos. Conheço casos de pessoas que estão afastados por doenças relacionadas ao trabalho LER ou 
DORT, que trabalham 12 horas em casa com confecção. Avalio muito os bateristas que fazem aquilo por prazer, que têm movimentos repetitivos durante muito tempo, ensaia 4 horas por dia, ainda fazem shows e não sentem nada porque fazem aquilo por prazer. É uma reflexão que faço sempre.

34- Seria mais uma insatisfação mesmo da vida..., daquele trabalho?

Resposta: Existe também um fato que a gente conhece quando fiz algumas disciplinas aqui na ergonomia. Foi feita num banco que remodelou todos os postos e que os índices continuaram parecidos, não alteraram em nada em alguma coisa que pudesse ter valido a pena o investimento que tinham feito. Chegou-se a conclusão de que bastava trocar o gerente do banco para se poder realmente ter outros resultados, então, acho que os dois lados têm que ser avaliado.

35- Novamente as questões subjetivas...

Resposta: Tem uma pessoa aqui na UFSC, Francisco Fialho, que trabalha no curso de ergonomia cognitiva, acho que é uma pessoa que pode esclarecer muitas questões relacionadas a isso. A ergonomia cognitiva surgiu quando a ergonomia física da alteração do posto de trabalho não conseguiu mais dar conta. Então, trabalha muito com as questões da psicologia e das questões psicossomáticas de cada indivíduo.

36- Você já vem notando que existe uma característica especial nesse processo de elaboração e efetivação de um trabalho corporal no expediente de trabalho. Uma ginástica laboral que não só se justifica pela questão física mas, principalmente, pela questão mental. Em outra oportunidade que nós conversávamos você achava que a parte central, o eixo desse trabalho e o que mais atinge é essa questão do bem estar emocional.

Resposta: Acho que existe muitas questões que têm que ser associadas. Primeiro a empresa está te dando, 10 a 12 minutos. É um investimento que a empresa está fazendo.

37- Diretamente para o indivíduo, indiretamente para ela.

Resposta: Como nós não temos dados que comprovem que a ginástica aumenta a produtividade, os dados que temos comprovados nas 64 empresas que temos implantadas hoje, pode-se afirmar que realmente há melhoria do clima organizacional, do bem estar. Com certeza, um ambiente de trabalho melhor, mais "gostoso", com certeza o rendimento virá. Mas é que o rendimento é uma coisa subjetiva, é de cada um, é muito importante perceber isso. Você pode ser uma cara mais treinada funcionalmente e vai produzir só se você quiser. Então se você quiser trabalhar no seu ritmo o resto de sua vida, você vai trabalhar independente de estar bem ou mal. Vi casos de pessoas que estão mal, estão doentes e continuam a fazer um esforço tremendo para produzir a mesma coisa e outros que estão excepcionalmente bem fisicamente mas as oscilações psicossomáticas acabam interferindo na sua produção. Então o que acredito é que o programa de ginástica não tem uma relação direta se você está mais forte, mais bem preparado, mais resistente. Talvez isso possa vir mais lá para frente. Mas acho que principalmente a melhoria do clima organizacional é o grande ponto. Dentro a gente tenta respeitar em cada um dos trabalhadores a tradução de um estilo de vida mais ativo, isso é que é o fundamental. A partir daí vai levar isso para família, para o seu filho.

38-Você possui dados indicando se houve alteração ou não?

Resposta: Ainda não, nós estamos nesse momento fechando uma padronização a nível estadual para execução do trabalho.

39- Eu estou querendo saber disso...

Resposta- Num próximo momento seria para a gente avançar nas questões das medições.

40- Nessas questões que você observou sobre o clima organizacional do trabalho e bem estar, também não temos instrumentos para avaliar isso?. 
Resposta: Não, isso é muito subjetivo, vai muita da pessoa, da "sensibilidade", exatamente de quem observa, daquilo que se escuta dos empregados, dos trabalhadores e da gerência. Até porque das 64 empresas tem 4 ou 5 que começaram em 98, e essas continuam até hoje, isso significa que pode ser algum reflexo, um deles seria para própria questão da gente está fazendo um bom trabalho, estar gerando frutos positivos dentro da empresa e a empresa conseguir perceber que aquele investimento tem resultados práticos, independentes de quais sejam, porque ninguém investe 800 ou 600 mil reais por mês se não tiver resultados práticos interessantes. Só que infelizmente a gente ainda é amador no que diz respeito a medição. É uma coisa que ainda temos que evoluir.

41- Está começando a se apresentar uma questão que é de certa forma nova.

Resposta: Principalmente porque temos uma diversidade de informações profissionais muito grande. Hoje em SC temos 13 universidades que forma profissionais de educação física. Que qualidade estas Universidades têm? Como funcionam? Quem sabe?

42- Abre o campo para os professores de educação física, mas ao mesmo tempo exige um conhecimento elaborado.

Resposta: Além disso, não conheço nenhuma grade curricular que fale sobre a ginástica laboral.

43- È uma coisa nova, não é?

Resposta: É, exatamente, nova. Mas isso significa que os currículos estão sempre defasados com a atualização do mercado. Temos essa dificuldade quando precisamos contratar professores por aqui. Ginástica laboral...tive uma experiência aqui e o outro nunca ouviu falar...Acho que pode ser um passo para uma legitimação profissional.

44- Muito interessante, quer dizer, a universidade com o curso de formação do professor de educação física tem que estar adequada ao que a realidade social está impondo?

Resposta: Na verdade num curso está se formando os profissionais para o mercado, quando as universidades se preocuparem efetivamente com isso, talvez os programas de ginástica na empresa já não estejam tão em voga dentro das empresas, talvez já tenham cumprido seu papel, acredito muito na questão da moda. Se não entendermos a perspectiva do programa de ginástica na empresa como um programa educativo, acho que ele morre nele mesmo. Se a gente entender que não é só para prevenção de LER, de DORT, não porque não somos máquinas, acho que não cumpre seu papel e vai acabar nele mesmo.

45- E sobre a empresa da pesquisa. É a empresa que adotou o programa há mais tempo?

Resposta: Não, a (...) está desde janeiro, mas tem uma perspectiva muito interessante. Nós começamos lá por uma questão política do nosso coordenador, o gerente de lá o SR...., realmente foi muito feliz, porque brigou muito para que a gente entrasse na (...). Porque a (...) já tinha um profissional fazendo ginástica laboral lá. Então nós entramos em janeiro com um grupo de 200 pessoas e hoje nós temos 1.400 trabalhadores. Nos deram uma célula numa fábrica muito pequena, viram a qualidade de nosso trabalho e começamos a crescer. Conversei com um dos engenheiros, o...engenheiro de segurança e ele disse que até 2002 querem estar com 7.000 trabalhadores fazendo ginástica laboral.

46- Já incluído no planejamento estratégico?

Resposta: Então estamos fazendo um crescimento progressivo...

47-Então você sabe os interesses deles. Por que eles estão tão empolgados?

Resposta: Eles conseguiram perceber. O SR. ..., que é o presidente, falou para o nosso superintendente, no aeroporto, que a ginástica laboral é fabulosa, porque elevou o clima organizacional, porque as pessoas estão mais felizes, porque gerou um movimento diferente dentro da empresa e ele é uma pessoas extremamente preto no branco. 
48- Objetivado?

Resposta- Sim, ele só quer saber no que dá dinheiro, no que não dá, não interessa. E ele consegue perceber, mesmo nós não tendo uma possibilidade de avaliar se aquilo tem um retorno financeiro. Ele conseguiu fazer uma avaliação subjetiva do que estava acontecendo. Ele conseguiu perceber que mesmo sem ter dados, porque são muito comuns para um empresário, os dados, mesmo sem ter dados relativos a isso, ele se convenceu. E ele passou a fazer um papel muito importante de manutenção nos médios gerentes, as pessoas se convencem que aquilo é interessante. Então, um gerente ouvindo do presidente da (...) uma das maiores de SC, de ponta, ele consegue perceber que o programa é bom, então os gerentes ouvindo... influencia.

49- Sobre a questão salarial como é que está? Numa pesquisa que fiz em MG os trabalhadores estavam bem satisfeitos com a questão salarial, e aqui, você sabe?

Resposta: Eu não sei efetivamente...

50- Teria alguma coisa mais importante a falar desse programa?

Resposta: Acho que o mais importante é a questão de ter essa perspectiva diferente...

51- E também de estar atingindo coisas que a gente não pode dizer o que são, mas que percebemos que acontecem.

Resposta: Hoje a gente está sensibilizado para tentar descobrir algumas coisas, para tentar realmente quantificar algumas coisas que a gente sabe que está atingindo, mas hoje a gente não sabe exatamente o que é, como é que está fazendo e o que é que realmente está acontecendo.

52- As interferências são positivas...

Resposta: Temos crescido de forma muito grande, dentro das perspectivas do que tínhamos em 98 e hoje temos 64 empresas, 15.000 trabalhadores, a melhor propaganda quem faz são os empresários, porque eles têm os canis deles e eles é que fazem. Nós somos o único SESI no Brasil, o SESI é líder no mercado dentro deste contexto, que temos duas plataformas em alto mar. Plataformas da Petrobrás, uma em Itajaí e outra em Santos, é de lá, mas o programa é daqui. O prof. tem que se deslocar de helicóptero, tem que dormir lá. E a Petrobrás é extremamente exigente. Tem características próprias no expediente de trabalho.

53- Como vocês fazem a abordagem na empresa, venda do produto ginástica laboral, etc?

Resposta- Quando uma empresa gera uma demanda, nós vamos lá e apresentamos o programa de forma simplória para que eles saibam da forma como vai funcionar. A empresa pede um orçamento e nós vamos na empresa e fazemos um diagnóstico, às vezes perdemos 5 , 6 horas fazendo o diagnóstico.

54- O diagnóstico é feito em cima de que elementos mesmo?

Resposta- Das condições laborais, não só do que eles fazem ali, mas como são supervisionados, que tipo de esforço eles fazem, como é o ambiente ali, se é bem iluminado, se tem risco físico, mecânico, ergonômico, biológico, então a partir do diagnóstico, a gente faz uma planilha de custos e passa para a empresa e no OK, a gente faz um plano de implantação com cronograma de 3, 12 meses como a empresa quiser. Das palestras, fazemos as intervenções e depois se faz uma palestra de sensibilização para os colaboradores, podendo abranger alta gerencia, no caso de colaboradores só alta gerência, não só alta gerência, depende da quantidade, Depois fizemos a seleção dos facilitadores, caso a empresa não queira trabalhar com facilitador, trabalha com estagiários, ou prof. de educação física, isso acaba onerando um pouco mais, depois desta seleção, faz-se um treinamento para estes, dependendo do grau de instrução destas duas ou três horas de treinamento, depois há a aula inaugural e se inicia o programa. 
55 Os facilitadores não são professores de educação física. São retirados entre os próprios trabalhadores. Será que não estão executando uma tarefa que seria de outro profissional?

Resposta- Não sei, eles só repassam a série. Acho que um profissional de educação física, estuda 4 anos e acho que tem muito mais o que fazer do que chegar lá e passar uma série. A certeza que eu tenho que o facilitador cumpre bem o papel dele, porque muitas vezes ele passa a ter o papel de líder, é muito bem quisto na empresa e ele vai simplesmente repassar informações, a gente orienta que ele não tem o papel de correção e o nosso professor quando passa na empresa semanalmente ou duas vezes na semana é que vai fazer esse papel de correção e vai dar todos o feedback para o facilitador.

56- Pode ser que com o tempo seja um professor quem vai dar essa aula; se começar a atingir claramente outros elementos?

Resposta- Sim, mas normalmente o professor de educação física sofre uma rotatividade muito grande e acaba não tendo treinamento para realizar o trabalho especificamente numa empresa. Porque o ato de você ir lá e passar os exercícios é o mínimo, acho que o especial está por fora: conseguir fazer com que a pessoa deixe de ser um sedentário e passe a ser uma pessoa pelo menos um pouco ativa. Fazer com que estas pessoas tenham algum tipo de atividade. Eu tenho a perspectiva que o facilitador cumpre bem o papel dele, até porque nesses 3 anos não temos nenhuma reclamação.

57- Vocês fiscalizam? Existe algum controle?

Existe. Duas vezes por semana o professor de educação física passa e as séries são trocadas entre 25 e 30 dias e o facilitador recebe novo treinamento, porque muitas vezes também a série acaba sendo extenuante e as pessoas ficam de saco cheio de fazer os mesmos exercícios, chegamos a essa conclusão 


\section{ANEXO 03 \\ Entrevista com a $1^{\text {a }}$ CoOrdenadora do Programa Ginástica na empresa do SESI, EM JARAGUÁ dO SUL (SETEMBRO DE 2000)}

01-Qual é o objetivo fundamental dessa proposta de ginástica na empresa?

Resposta- Através da melhoria da qualidade de vida no trabalho melhorar a qualidade de vida também fora do trabalho, em casa. Fazer com que as pessoas criem hábitos de lazer, com que elas tenham uma maior longevidade no trabalho, porque hoje as pessoas se aposentam muito cedo em conseqüencia do trabalho repetitivo.

02- Você sabe se esta proposta teve alguma influência do toyotismo?

Resposta- A ginástica começou mesmo na Holanda depois foi difundida no Japão, mas aqui no Brasil ela adquiriu uma característica própria, até pela cultura de nosso país, então não vejo referência direta com a ginástica que é feita hoje no Japão, diria que é mais adaptada a nossa realidade, que aqui é até regional, talvez.

03-Em quais fundamentos você se baseou para elaborar esta proposta?

Resposta- Na busca da socialização, principalmente, por isso nossos trabalhos são todos feitos em células, fazendo com que as pessoas olhem umas nos olhos das outras, com que elas conversem. Porque durante o período de trabalho em se tratando de linha de montagem, principalmente, as pessoas não tem muito tempo, nem para conhecer a pessoa que está a sua frente. Então os objetivos são esses: socialização, integração, melhorar a relação interna entre eles.

04-O que são células?

Resposta- São grupos de trabalho. Para cada 16 pessoas nós treinamos um facilitador, e esse grupo de trabalho forma uma célula. Dentro de uma empresa com 200 funcionários nós podemos ter 19 a 20 células.

05- Elas são mutáveis ou são as mesmas sempre?

Resposta- Elas se modificam, principalmente os facilitadores. Os facilitadores são trocados a cada 6 meses até porque há uma adesão bem grande de pessoas que querem participar como facilitador do programa porque eles sabem e tem consciência que é uma chance de mostrar uma característica que durante o trabalho dele não tem condição que é de liderança, até de capacidade de liderança de um pequeno grupo, ali eles conseguem um diferencial dentro da empresa.

06- Eles expõem a capacidade de liderança uma vez que esta capacidade fica escondida na linha geral de montagem?

Resposta- Ele se limita a um único tipo de trabalho durante 8 horas por dia, naquele momento da ginástica, talvez o único momento que ele tem para mostrar outras características que não é de fazer só o trabalho dele corretamente. Um trabalho manual, mas expor características próprias, pessoais, de liderança, disciplina, organização, durante o trabalho dele ele não tem. Ali mesmo dentro destas células, às vezes, criam-se situações em que eles mesmos têm que resolver as questões, então a criatividade, a dificuldade em falar com as pessoas. Na nossa pesquisa com os facilitadores foi o que eles mais relataram que melhorou muito a capacidade de comunicação deles.

07- Os facilitadores têm um papel concorrido, todos querem?

Resposta- Não digo todos, mas a grande maioria quer ser e muitas vezes a gente se surpreende demais porque algumas pessoas que se mostram inicialmente muito tímidas em muitas vezes até os chefes acham que essa pessoa não vai ter condição de administrar um grupo de trabalho, essas pessoas são as que se mostram mais capazes.

08- Ou seja, é a oportunidade para expressar coisas que estão guardadas, que lhes são 
próprias... é interessante...

Resposta- Muitas vezes eles têm dificuldades de mostrar no dia a dia. Por isso é que no treinamento com os facilitadores procuramos passar para eles que não podem ter vergonha; usamos muito de dinâmica para fazer com que as pessoas se soltem, se descontraiam, para quando estiverem à frente do grupo deles não tenham vergonha de falar alto, de usar os artifícios de entonação de voz para motivar seu grupo de trabalho.

09- Que atividades são essas?

Resposta- São atividades geralmente recreativas onde eles têm que se colocar a frente do grupo e realizar alguma tarefa, ou tem que coordenar alguma tarefa para o grupo, ou falar algum assunto para o grupo e as pessoas então tem que buscar a sua forma de se comunicar com o grupo de trabalho.

10- Qual a concepção de corpo que vocês estão trabalhando ali?

Resposta- A gente procura trabalhar o corpo como um todo, até porque durante o trabalho deles eles utilizam só um segmento do corpo principalmente o superior e a corporeidade deles fica muito limitada, então durante as primeiras séries de exercícios a gente percebe as dificuldades que eles têm no movimento simples e a partir do momento que o programa é implantado a gente vai acompanhando ao longo de 3 ou 4 meses, a gente já percebe que a percepção deles de corpo mudou, porque eles conseguem perceber já os exercícios sem que muitas vezes a gente tenha que demonstrar, se eu falar o exercício, descrever, eles conseguem mentalizar, conseguem reproduzir esse exercício mentalmente e depois fisicamente, que antes eles não tinham condições de fazer.

11- Antes vocês usavam a metodologia da imagem gestual?

Resposta- Da imagem, do gesto, da visualização, o facilitador demonstrava o movimento e eles repetiam, aos poucos, a gente vai retirando a visualização, a gente só fala o exercício e eles tentam reproduzir esse exercício sem ter a planilha na frente com a ginástica especificamente ali no desenho. Nesta fase que eles se encontram agora, a partir do quarto mês, eu não entrego a planilha para eles antes do final da aula, eu só descrevo o exercício e eles têm que reproduzir o exercício para mim, eles tem que imaginar o que estou falando para eles e desta forma reproduzir.

12- Você acha que isso indica um trabalho corporal internalizado?

Resposta- Exatamente, já começa existir uma consciência corporal, inclusive dos exercícios que estão sendo executados da forma correta ou não, sem que para isso eles tenham que visualizar, eles podem perceber no próprio corpo sem ter que estar olhando para perna, eles conseguem perceber que o movimento está errado, e se auto corrigir.

13-Sobre a questão do modelo do gesto, você já havia comentado que não havia um modelo correto, as pessoas não tinham que se preocupar com isso, com um padrão...

Resposta- Não, isso vai acontecendo naturalmente, é um processo natural, por isso, no começo eles tem que se guiar pelas figuras até por essa falta de expressão corporal e pela falta de vivência de atividades físicas, mas aos poucos os facilitadores, a gente corrige, só pedimos que eles não façam correções no grande grupo até porque são pessoas do mesmo nível de trabalho, são pessoas que estão começando, então ele não tem condições de fazer correções até por não serem professor, para não constranger, para não criar inimizades, porque algumas pessoas aceitam a correção outras não, então quem tem que corrigir é o professor. Eles anotam na planilha, quando a gente passa para fazer a supervisão eles chamam o prof. e fala que a determinada pessoa está com dificuldade neste ou naquele exercício, ou eu mesmo entro no grupo e pergunto se alguém tem alguma dificuldade em algum exercício, ou se observo entro centro da célula e faço a correção para todos e nunca para uma pessoa especificamente.

Obrigada! 


\section{ANEXO 04 \\ Entrevista com a $2^{\mathrm{a}}$ CoOrdenadora do Programa Ginástica na EMPresa do SESI EM JARAGUÁ DO SUL ( JUNHO DE 2001)}

1- Quais as principais diferenças que você está implementando no Projeto de Ginástica nessa empresa?

Resposta- Tudo o que eu peguei está continuando, as dinâmicas, a caminhada, eles estão fazendo. $O$ que mudou, na fábrica " $X$ " foi o exercício em dupla, que eu tinha te falado, eles não aceitam mais o exercício de pegar, o toque, eles não aceitam.

2- E as turmas todas, elas não aceitaram mais?

Resposta- A princípio, a maioria não quer, mas a mais resistente foi uma turma só, que eu te falei, é o pessoal da usinagem.

3- Do primeiro turno?

Resposta- É.

4- E o que se alterou a partir do mal estar deles? Vocês trocaram os exercícios ou retiraram os que tinham toque?

Resposta- Isso.

5- Eles disseram para você que não queriam mais isso ou foi na reunião com os facilitadores?

Resposta- Não. Eles não falaram isso, eles não falaram diretamente para mim, mas eles colocaram numa avaliação que foi feita. A maior reclamação foi o exercício em dupla.

6- E aí, você retirou?

Resposta- Aí eu retirei, eu já tinha retirado porque eu já via que tinha alguma resistência. Aí depois eles confirmaram o que eu já estava vendo.

7- E qual foi a sua impressão desse trabalho corporal quando você chegou aqui na (...) para substituir a outra coordenadora?

Resposta- Eu achei que iria ter mais resistência até pela própria cultura, pela cultura alemã, por essa cultura machista que tem um pouco aqui, eu achei que as pessoas iriam ser mais resistentes a estar fazendo esse tipo de trabalho. Mas a gente tem hoje $97 \%$ de aceitação na maioria das fábricas que a gente trabalha.

8- Aceitação, a pessoa faz se quiser, não é?

Resposta- É.

9- Na verdade os que ficam de fora são sempre estimulados pelos colegas para não deixarem de fazer, é isso?

Resposta- Isso.

10- De forma alguma pode fazer pressão?

Resposta- Não, de forma nenhuma. Até porque a filosofia do programa não é essa, não é estar forçando as pessoas a fazerem.

11- E como você conseguiu acesso ao programa?

Resposta- Eu mandei o currículo...

12- Mas eu digo assim, ao conteúdo do programa, ao conhecimento que é utilizado.

Resposta- A ex-coordenadora me passou a proposta, foi ela que me passou. Porque a gente tem que seguir um padrão. Ela é que me falou, a gente tem esse passo, depois esse, tem a palestra para sensibilização que a gente conscientiza as pessoas que acham que muitas vezes não funciona. 
13- Você já disse que teve que fazer uma palestra para conscientizar os operários sobre a importância da ginástica?

Resposta- Eu tive que fazer outra palestra, outro processo, porque eles estavam distorcendo o objetivo da ginástica.

14- Os trabalhadores?

Resposta- Os trabalhadores, porque a maioria respondeu na avaliação que melhorou o condicionamento físico com a ginástica na empresa e isso é impossível. E aí eu comentei isso com eles, eu falei que o que melhora, que o objetivo da ginástica é diminuir o estresse, é quebrar o ritmo de trabalho, é acordar, despertar para o trabalho.

15- Estimular a concentração, também,?

Resposta- Isso. E esse tipo de trabalho em dez minutos nunca vai melhorar o condicionamento físico dele. Aí eu fiz a pergunta para eles: alguém aqui vem trabalhar de bicicleta? Alguns levantaram. Alguém vem trabalhar a pé? Alguns levantaram a mão. Então, você que vem de bicicleta ou vem a pé para o trabalho pode estar tentando algum benefício quanto ao condicionamento físico de vocês por esse motivo, mas não pelos dez minutos.

16- Mas antes eles não andavam a pé e não vinham de bicicleta também?

Resposta- Também. Eles não têm noção do que é isso, por isso que a gente até comentou que é bem psicológico a coisa.

17- Atinge mais o emocional?

Resposta- Sim.

18- E não o físico no caso?

Resposta- Isso.

19- Sabe-se disso, percebe-se que atinge mais o emocional. Mas, agora uma coisa que você falou: eles fazem a leitura errada do que eles estão fazendo. Eles estão fazendo uma coisa e elaborando como outra, percebendo outro objetivo que não é o que realmente está centrado. $\mathrm{Na}$ verdade é para atingir outro objetivo. Será que eles não têm uma crítica do que estão realizando, uma conscientização. Você notou isso?

Resposta- Notei.

20- Apesar de não saberem criticamente o que está acontecendo, mesmo assim eles gostam?

Resposta- Eles gostam e daí eles querem colocar coisas e querem mudar coisas que não é possivel. Tipo: eles querem que tenha exercício todos os dias diferentes, eles querem que mude a série toda semana e isso não tem como fazer porque foge do meu controle, eu expliquei isso para eles.

21- Eles estão solicitando isso nas reuniões dos facilitadores?

Resposta- Sim.

22- Querem a ginástica diferente todos os dias?

Resposta- Acham que está muito repetitivo.

23- E você foi saber por que eles querem mudar?

Resposta- Na verdade sabe qual é a impressão que me dá, é que por alguns assim, pela grande parte, eles querem a ginástica para ficar os dez minutos sem fazer nada.

24- É, eu também já notei isso.

Resposta- Por isso que a ginástica tem grande aceitação, não é por causa do exercício, eu vejo isso.

25- É um espaço que tem para um descanso? 
Resposta- De descanso, eles querem na verdade isso. E daí eu coloquei para eles, que é válido o descanso nos dez minutos, só que vocês vão voltar para o trabalho cansados do mesmo jeito e com a ginástica não, vocês vão voltar mais estimulados, eu falei isso para eles.

26- É um trabalho bem braçal que eles fazem não é? Quer dizer exige mais o físico e a ginástica na verdade pode servir para descansar.

Resposta- Quem trabalha em pé, a maioria trabalha em pé, quando tem a reunião com os facilitadores, eles não podem sentar. Sabe eu fico com pena, sinceramente de pedir para eles levantarem porque eu sei que eles estão há horas em pé, há horas fazendo a mesma coisa e todos os dias.

27- Mas, da ginástica as questões mais diferenciadas são essas?

Resposta- $E$.

28- O que modificou foi o toque, que não tem mais, quer dizer, que eles não querem. Não há como fazer um levantamento por que eles não querem isso?

Resposta- Não. Para você ter uma idéia teve um que colocou assim, nas palavras dele "ginástica em dupla é falta de higiene". Eu não sei se de repente eles estão com as mão sujas. Mas geralmente eu vejo, antes da ginástica eles vão lavar a mão e vão fazer a ginástica.

29- É uma coisa que não dá nem para ser estudada lá dentro, não é? Por que é uma coisa bem profunda, uma coisa relacionado ao corpo mesmo?

Resposta- É.

30- Por exemplo, fiz uma pergunta: o que eles gostavam mais do corpo deles. Eles tinham dificuldade para responder isso, todos. Ninguém tratou com naturalidade, foi assim: "Corpo o quê? O que você está perguntando?" Todos, ou riam ou ficavam minutos pensando; há uma relação aí sobre o toque que parece ser mais complicada do que a sujeira da máquina, do motor. E aí é bom ver isso fora da fábrica, ver se encontramos alguma resposta por essa via, do nojo do corpo.

Resposta- É porque na verdade eles não têm isso trabalhado, não têm essa consciência corporal trabalhada. E a ginástica procura trabalhar um pouquinho isto, mas mesmo assim é difícil romper. É difícil porque no simples fato de você perguntar, de você pedir para eles 'pessoal fechem os olhos, solta, relaxa. Pessoal, fiquem em dupla, olha um no olho do outro', mas nem pensar, ninguém olha. E olha que eu fiz esse trabalho com mulheres, não dá, elas não conseguem ter essa liberação, é cabeça baixa sempre.

31- Será que não são peças de uma engrenagem tal qual máquinas; eles não são pessoas ali. São um motorzinho que está funcionando. Então não vai dar toque no outro porque o outro é gente. Toque é uma coisa humana e como eles são máquinas, eles não podem ser humanos.

Resposta- É o tipo da coisa assim, como a gente está acostumada com essas questões, nós da educação física, eu estou muito acostumada. Quando eu converso com essas pessoas eu olho, eu toco, eu faço isso. Aqui, eu não posso fazer isso, porque se eu fizer eu estou cantando o outro, se eu fizer, eu estou sendo leviana com o outro, então eu não faço, homem eu não toco.

32- Eu queria saber, qual a sua experiência. Você observou que na fábrica eles não querem o toque corporal, mas você sabe, está percebendo que fora da fábrica as pessoas também não permitem, são fechadas?

Resposta- Não.

33- Houve uma constatação sua, que você não pode agir assim com as pessoas...da cidade!

Resposta- Agora, com algumas pessoas mulheres, uma ou duas, eu falo assim: 'Oi, tudo bom? Como é que está? E elas gostam.

34- Aproximam-se, pegam, tocam-se? 
Resposta- Elas se identificam, só que não é todo mundo. São algumas pessoas, tem uma ali, que ela é facilitadora da fábrica quatro, ela é uma pessoa assim, maravilhosa, ela é meiga, ela é calma, quando eu olho para ela, ela está sempre sorrindo. Eu chego: 'Como é que está? tudo bom?' Toco nela, ela me abraça e dentro de quantas mil pessoas que trabalham, uma faz isso. É estranho, para mim é estranho, porque eu não estou acostumada com esse tipo de coisa., desse afastamento. A gente está acostumada muito a tocar nas pessoas, é tão bom, não é? Chamar pelo nome, quando eu chamo (...), porque eu procuro chamar as pessoas pelo nome, elas adoram, mas elas, no tocar não, de jeito nenhum.

35- E fora da fábrica também você constata isso?

Resposta- Sim.

36- Socialmente, aqui na cidade de Jaraguá há um comportamento ...

Resposta- $O$ cumprimento aqui é só aperto de mão.

37- Um beijinho não existe?

Resposta- As pessoas que a gente cumprimenta beijando, são as pessoas de fora. As pessoas daqui, no cumprimento, não tem beijo, o normal é só um aperto de mão.

38- Interessante. Há uma complicação aí na parte emocional.

Resposta- As pessoas são muito frias.

39- O afetivo está bem difícil aqui, não é?

Resposta- Está bem em baixa.

40-E a questão do lazer, sobre o que conversamos lá fora. Você chegou à cidade e tem observado que realmente a prática de esporte é uma constante, é a prática de lazer daqui, não tem mais outra? Nada mais se faz aqui?

Resposta- Que eu saiba não. Que eu saiba é o futebol e no verão as pessoas vão para a praia.

41- E passear?

Resposta- No máximo no parque da Malwee, fazer um churrasquinho no parque da Malwee no final de semana. Mas dizer assim, hoje a maioria está saindo para ir o final de semana em outra cidade, isso aí é muito difícil acontecer. Assim, saem para passear, mas quando?

42- Eu perguntei para os trabalhadores da fábrica, qual é a estatística? E eles responderam: "De vez em quando, quando pode." Eles querem, mas eles não fazem.

Resposta- Eles trabalharam de segunda a sexta, de segunda a sábado e quando eles estão em casa, eles estão trabalhando em alguma coisa da casa. Eles não estão descansando, eles estão trabalhando. Sabe, até um engenheiro de segurança falou para mim que o maior problema deles hoje é o segundo turno, porque as pessoas que trabalham o segundo turno, começam às 02:18 e vão até 23:18.

43- 02:18H da manhã, das 14:18 às 23:18.

Resposta- 02:18H da tarde, o segundo turno. Então, nesse período da manhã, ao invés deles estarem descansando, eles estão trabalhando em outra coisa, em casa, ou em outro emprego, bico, essas coisas, então eles chegam no trabalho cansados. Porque, imagina, não agüentam, no período que tem que estar descansando, estão fazendo outra coisa.

44- E trabalham bastante, não é?

Resposta- Nossa, direto.

45- E no trabalho pesado.

Resposta - É.

46- Quer dizer, aqui é a cidade do trabalho?

Resposta- É. 
47- As pessoas todas têm que trabalhar o dia todo sempre, se não, é considerado vagabundo, isso é o que passa na cabeça deles?

Resposta- Tanto é que aqui não tem favela, não tem mendigo na rua, não tem ninguém pedindo.

48- E onde estão estas pessoas? Porque aqui sendo uma cidade industrial poderia explicitar mais algumas contradições sociais.

Resposta- Eles são mandados embora, geralmente. Eu não sei, dizem que tem pessoas na rodoviária para fiscalizar quem entra em Jaraguá, para saber se chega meio sem rumo, aí eles vão tipo perguntando: "O que veio fazer? Eu vim procurar emprego. Eu vim aqui sem nada. Aí, eles mandam de volta. Isso foi o que me falaram, eu não sei se isso acontece.

49- A liberdade de ir e vir aqui não existe?

Resposta- E se a pessoa vem sem destino, sem uma casa para morar, sem um emprego, sem uma perspectiva de emprego, não fica.

50- Em todas as dimensões há controle para que a pessoa obedeça às regras do trabalho?

Resposta- Sim. Eu vejo que as coisas aqui são um pouco mais caras, eles são mais exigentes, justamente para não vir ninguém de fora (...)

51- Com pouco ou sem dinheiro?

Resposta- É. Para selecionar mesmo as pessoas, eles querem na verdade é selecionar a população de Jaraguá, para não ter mendigo, para não ter pedinte, para não ter nenhum tipo de coisa que vá modificar o estilo de vida deles.

52- E os espaços públicos de Lazer aqui, você tem visto?

Resposta- Eu vejo sim, mas é tudo na área do campo de futebol.

53- Porque eu vi tudo fechado nas minhas observações. Como se poderia ter acesso a esses espaços se não estão abertos? Eu vi tudo cercado, tudo gradeado. Como é que a pessoa entra ali se além de gradeadas as quadras estão também com cadeado? Eu achei estranho isso, porém gostaria de entender.

Resposta- Eu também não sei. Eu vejo alguns campinhos de futebol. Está escrito pela Prefeitura: "área de lazer".

54- Mas estava sem ninguém, não é?

Resposta- A gente nunca vê ninguém, todo mundo está trabalhando.

55 - E à noite, eles jogam?

Resposta- Jogam, mas não nesses campinhos eu não vejo. Mas no SESI toda noite.

56- Tudo é planejado?

Resposta- Tudo é planejado, tudo é organizado, tudo certinho.

57- Nada é espontâneo?

Resposta- Não.

58- Qual seria a sua síntese sobre o lazer da cidade?

Resposta- $O$ lazer aqui em Jaraguá se restringe ao futebol.

59- Você está no departamento de lazer do SESI, não é quem promove esses eventos?

Resposta- O lazer aqui se restringe muito ao futebol e aos homens. As mulheres, agora com os jogos do SESI, agora que tem jogos de baralho, bolão, esse tipo de coisa, vôlei, para as mulheres, mas as mulheres é bem restrito. A grande maioria é homem que participa.

60- As mulheres estão em casa?

Resposta- Sim. E quando não estão em casa, estão trabalhando. 
61- E as mulheres, você já teve a oportunidade de conversar com algumas mulheres lá da fábrica, por exemplo, sobre isso, ou no SESI?

Resposta- Não. Eu conversei com uma que não trabalha mais na (...), ela trabalhou vinte anos na lá. Ela trabalhava no primeiro turno, começava as 04:00H da manhã até 14:18H e ela tinha que chegar em casa e fazer as coisas tudo de casa, cuidar dos filhos. E aí os filhos foram crescendo assim desse jeito e ela me falou uma coisa que eu fiquei assim meio assustada, ela disse assim: "Eu acho que eu não me acidentei no meu trabalho foi por Deus, porque cansava de estar trabalhando e estar pensando nos meus filhos em casa. A minha cabeça estava fazendo o meu trabalho, mas a minha cabeça estava na minha casa. Eu não sei como até hoje eu não tive nenhum acidente. Eu acho que é por Deus mesmo" Ela falou isso para mim.

62- E nunca houve acidente? - Não.

63- Ela se aposentou?

Resposta- Ela com vinte anos de firma, ela saiu porque o marido dela também trabalha ali na (...) Ela saiu porque eles queriam que ela estudasse e aí ela disse: "Eu não vou ter condições de trabalhar, de estudar, de cuidar de casa." Hoje as filhas dela são grandes, adultas. Aí o marido dela falou "tu sai, se tu quer sair descansar um pouco." Aí ela não quis mais, não quer mais saber.

64- E perdeu o tempo de trabalho, as obrigações sociais, as garantias?

Resposta- Isso eu não sei dizer.

65- Você tem alguma opinião que gostaria de dar, alguma análise a partir desse seu trabalho todo, do que você está vendo como impressão mesmo? Você veio de fora, de uma cidade de praia, Florianópolis, chegou aqui com tanta coisa diferente.

Resposta- A minha impressão sobre as pessoas é que ao mesmo tempo que elas necessitam de afeto, de carinho, de uma pessoa que converse, elas se fecham para aquilo. Elas têm medo, não sei se é medo a palavra, elas têm sempre uma desconfiança das pessoas. Se tem alguém com alguma coisa diferente, ao mesmo tempo que elas acham que pode ser legal, mas elas também têm esse medo. Porque a mudança traz essa coisa de se questionar: 'Será o que ela quer da gente?' Porque na verdade a gente está meio que invadindo o espaço deles. É uma invasão.

66- Eles ficam todos assustados com as pessoas de fora?

Resposta- Sim.

67- Existem muitas pessoas de fora, porque o pessoal da (...), os cargos de gerência me pareceu que são, na maioria, de outras cidades, outros Estados, enfim, há um monte de gente de fora, não é?

Resposta- Sim. Tipo engenheiros, a maioria é de fora.

68- E não estão alterando a cultura daqui, essas pessoas de fora, não conseguem alterar?

Resposta- Não, é mais fácil a gente se adaptar a eles, do que eles se adaptarem a nós. Tanto é que se a gente não prestar atenção, a gente começa a viver igual a eles. Da casa para o trabalho, do trabalho para casa, porque o ritmo é tão intenso, tão acelerado que tu começa a assimilar aquilo ali, tu começa a se acostumar com aquilo. As horas voam aqui, os dias passam que parece que tu não teve tempo de fazer metade do que tinha para fazer. Um mês aqui passa voando.

69- O tempo aqui é rápido?

Resposta- O tempo é rápido, quando a gente vê é sexta-feira, quando tu vê é segunda-feira e aí passa aquela semana tudo de novo e já é sexta.

70- E muito trabalho e muita coisa para fazer? 
Resposta- E muita coisa para fazer.

71- Mas também há aquela coisa do alcoolismo, da separação, do divórcio.

Resposta- Aí tem uma questão assim, eles odeiam carnaval. Tu sabia disso?

72- Eu sabia. Eles têm uma festa alemã aqui, que eles fazem, não é?

Resposta- É. Aí chega em outubro tem a Schützenfest - a Festa do Tiro, para eles é o carnaval deles, eles se soltam, aí é a hora que eles se soltam. Cai a máscara na festa, nestas festas. Aí eles são totalmente diferentes.

73- Eles dançam?

Resposta- Eles dançam, eles pulam, eles brincam, eles gritam, eles bebem.

74- É um mês o período de festa?

Resposta- Não, eu acho que duas semanas. Para você ter uma idéia, é valorizada tanto essa festa que se tu chegar todos os dias meio bêbado na empresa o chefe não chama a tua atenção.

75- Nesses quinze dias?

Resposta- Sim.

76- Por que não tem problema, é a festa?

Resposta- Sim. Mas se tu faltar o trabalho num dia de carnaval, na segunda-feira de carnaval, tu pode ir até para a rua.

77- Por que o carnaval aqui não existe?

Resposta- E eles acham um absurdo o carnaval.

78- Quer dizer, eles têm a cultura alemã; a cultura brasileira não existe para eles?

Resposta- Não.

79- Existe uma festa desprovida de repressões, porém não é o carnaval. É a Schützenfest? Resposta- É. 


\section{ANEXO 05 \\ ENTREVISTA COM O GERENTE DE CULTURA (LAZER) DA SECRETARIA DE EDUCAÇÃO DO MUNICÍPIO DE JARAGUÁ dO SUL (NOVEMBRO dE 2001)}

01- Você é o Gerente de lazer?

Resposta- É, eu sou mais da parte cultural, eu sou gerente de cultura. Nós temos na Prefeitura um departamento de lazer, mas esse departamento eu trabalhava o ano passado, então eu tenho bastante conhecimento nessa área, por exemplo, no que ele desenvolve. Se você quiser se aprofundar mais, daí você poderia conversar com algum deles, eu já liguei para eles. Mas eles falaram assim, "tu conheces até mais do que nós". Porque eles começaram esse ano e não é a área deles. A área deles é mais a técnica em educação física, eles estão dedicados a área de esportes. $O$ nosso departamento está ligado mais a parte de esportes.

02- E aquele moço que saiu?

Resposta- Não, o Miguel também faz parte da 'cultura'. O Miguel faz parte de eventos culturais e se a gente for fazer uma análise a cultura e o lazer estão juntas. A gente trabalha muito com eventos.

03- Pois é, esse é o ponto sobre o qual eu queria conversar com você. Como é que vocês unem e separam: cultura, lazer e esporte? Por exemplo, você citou o esporte e como é que se separa ou junta à cultura? Você é gerente de cultura da Secretaria de Educação do município?

Resposta- Sim.

04- E você é responsável pela gestão pública de lazer da cidade, não é isso?

Resposta- Isso.

05- Então, em cima de que elementos vocês unem ou separam a cultura e o lazer nesses eventos?

Resposta- Na parte hoje da fundação cultural a gente trabalha muito com eventos na área de dança, com eventos na área de recreação nos bairros: a chamada caravana da alegria - é um onibus adaptado para levar as brincadeiras para os bairros. Então a gente leva uma série de brincadeiras, de atividades culturais, palco e recreação e a gente trabalha muito os shows na praça.. A nossa praça depois que a gente faz esse show, geralmente tem uma média de um por mês, já foi mais, mas a nossa comunidade ela reclama muito. Você tem que ser pontual até 22:00 horas, não pode passar desse horário, então nós tivemos que limitar já o tempo, mas os jovens pedem muito esses shows. E nós temos também desenvolvido um trabalho voltado para as associações de tiro que é muito forte aqui em Jaraguá do Sul.

06- Quais são as atividades culturais como expressão de arte de um povo, aqui acontece essa festa do tiro e aquela outra festa, como é o nome?

Resposta- A Schützenfest.

07- É alemã, não é?

Resposta- $E$.

08- E é essa a festa famosa daqui?

Resposta- Isso, é a maior festa de Jaraguá do Sul.

09- Inclusive os materiais são trazidos da Alemanha mesmo?

Resposta- Isso. 
10- Você colocou isso na sua monografia, não foi?

Resposta- Isso, coloquei. Ela se caracteriza como sendo a mais autêntica. Ela se autocaracteriza e até por comentários de outras pessoas, que tem vindo visitar a festa, ela é a mais autêntica festa alemã de Santa Catarina, digamos assim. Porque ela mantêm uma tradição. Porque não é só o que ocorre na Schützenfest mas é o ano todo. As sociedades fazem a sua festa de rei...

11- É um componente que também está na sua monografia?

Resposta- Isso.

12- $\mathrm{O}$ ano inteiro ela se desenvolve?

Resposta- $O$ ano inteiro ela se desenvolve. E tem a culminância nesses dias de outubro, onde é realizado, aqui no nosso parque de eventos é a Schützenfest. É uma tradição muito forte aqui, os clubes alemães é um dos maiores clubes de associados do mundo, são 23 sociedades de tiro, que são sociedades aqui do vale do Itapocu.

13- Existe uma festa grande que absorve o trabalho do ano inteiro?

Resposta- Isso. Então, cada sociedade faz a sua festa individual.

14- Cada sociedade, seriam os clubes?

Resposta- Os clubes de sociedade de tiro que fazem a sua festa e culmina com a Schützenfest. Então ela se caracteriza como a mais autêntica alemã por causa disto. Não é só você reunir uma porção de gente, num pavilhão, pôr música alemã e pôr para dançar.

15- Como Blumenau?

Resposta- Não criticando, cada um tem a sua maneira, mas ela tem uma história e os organizadores tentam preservar essa história.

16 - E essa história se desenrola durante o ano, as pessoas se preparam e nos seus clubes e elegem o rei, não é isso?

Resposta- Isso. O rei e a rainha.

16- Informaram-me que essa festa correspondente ao carnaval brasileiro que não acontece aqui.

Resposta- Isso. O nosso carnaval é muito difícil aqui.

17- Vocês nem têm nada aqui, no carnaval?

Resposta- Isso. A gente conseguiu no ano passado fazer num sábado e no domingo, não na sexta e no sábado de carnaval. No domingo a gente não conseguiu porque o pessoal trabalhava na segunda e na terça, também não conseguimos fazer nada porque também durante o dia as empresas trabalharem.

18- Ou seja, carnaval aqui não existe?

Resposta- Não temos a tradição do carnaval.

19- Mas a festa é parecida?

Resposta- É, hoje já está bem maior o movimento do carnaval porque muitos (...), já começaram uma miscigenação, daí muita gente que está vindo de outras cidades, de outros estados, tem essa cultura. Mas, há alguns anos, uns dez anos atrás, eu não quero ser muito pessimista, mas era muito difícil ter o carnaval aqui. Na quarta-feira de cinzas, é que se absorvia um pouco do ritual do carnaval, o pessoal parava para rezar, mas para pular o carnaval, era geralmente o trabalho (...)

20- Como é que fica essa questão da religiosidade? A cultura alemã possui qual religião?

Resposta- Hoje elas são divididas, a religião católica e a luterana, digamos assim. Eu acho que um pouco maior é a católica, devido a grande miscigenação que teve. Mas, as quatro etnias básicas da formação de Jaraguá do Sul foram os alemães, se a gente colocar em 
proporção aí até hoje, os alemães, os italianos, os poloneses e os húngaros e aí depois os afro-brasileiros que ajudaram na formação dessa cidade.

21- Aqui existe negros, assim socialmente (...)?

Resposta- Hoje, organizados, estão começando uma organização.

22- Eles participam dessa festa?

Resposta- Da Schützenfest não. Eles participam da Schützenfest como público. Mas nas sociedades em si, dificilmente você vê um negro ou até de outras etnias, um italiano, praticando tiro para participar dessas associações (clubes). Não.

23- E esse tiro, não é muito caro esse esporte?

Resposta- Ele é um esporte caro, até toda a renda da Schützenfest vai para as associações, a Prefeitura ou os organizadores não ficam. Então, dividem entre os 23 clubes que participam da festa, até para manter. É um esporte caro devido a munição, e você tem que importar os armamentos, é assim.

24- E tem segurança também?

Resposta- Tem.

25- E quanto a violência de hoje não existe uma preocupação?

Resposta- Não.

26- Nunca houve problemas?

Resposta- Não. Até porque a característica é como prática de esporte, eles utilizam para o lado bom. Então, isso é interessante também porque você pode ter uma arma. Até um carro, se está nas mãos erradas se torna uma arma.

27- Nunca fizeram essa relação que o tiro pode estimular uma prática violenta. Uma festa que tem tiro? Mata o quê?

Resposta- Não, nunca fizeram. É só o alvo. A representação é de um tiro ao pássaro, mas é um pássaro que as mulheres pegam e atiram contra o ... Ela é até pouca, por exemplo, assim violência, até alguns clientes, como em toda a festa (...), mas é muito pouca.

28- O pessoal, eu soube, não por órgão oficial, mas em conversas, que aqui se bebe muito, é verdade?

Resposta- É verdade. Se a gente vincular, principalmente hoje a bebida com os jovens, Jaraguá do Sul é uma cidade que tem uma renda per capita boa, podemos colocar assim. Uma qualidade de vida boa e o pessoal começa a trabalhar muito cedo, os jovens começam a trabalhar cedo e já começam adquirir seus bens.

29- Eu vi na empresa que pesquiso, muitos jovens já no batente.

Resposta- Isso. E se você der uma volta na cidade, domingo à noite, na avenida principal, você vê muitos jovens na rua consumindo bebida alcoólica, com os seus carros, com o som ligado. Então, isso é uma estatística que nós não temos dados comprovados, mas que pelo o que a gente vê, é muito grande o consumo.

30- Eu tentei procurar saber, inclusive com colegas. Eu também soube que tinha muito suicídio, mas são dados que eu não consigo em órgão oficial nenhum. Mas se comenta isso em qualquer lugar.

Resposta- Isso. Até em eventos que a gente mesmo realiza, por exemplo, um show na praça, nós tivemos já (...), o pessoal vai e leva dos postos de conveniência, levam bebidas em caixas, vão, consomem e é difícil evitar. No local você até proíbe venda de bebidas alcoólicas, mas o pessoal traz de outros lugares. 
31- Seria um hábito também?

Resposta- $O$ próprio lazer, a diversão, dificilmente você pode desvincular da bebida.. Se você for numa festa de jovens, eu já trabalhei com alunos, não tem como não associar a festa, a primeira que se vai buscar é a bebida alcoólica.

32- Então, vocês concebem o lazer só de espetáculo, só de promoção de festa? Como é que ficaria isso junto à Secretaria de Educação que você colocou antes? Qual é a concepção de lazer que vocês estão tentando implementar?

Resposta- Quando a gente começou a trabalhar, há quatro anos, com a gestão de 96.

33- É isso que queria saber, é a primeira Prefeitura que tem gerente de lazer, ou sempre houve?

Resposta- Hoje, nós temos outro departamento que cuida da parte do lazer, que é a parte do esporte, daí são eventos de lazer. No departamento eles têm o superintendente de lazer dentro da secretaria de esportes, que depois se você quiser entrar em contato com eles, eu posso passar. Eles realizam, eles tem a chamada área de lazer aqui em Jaraguá do Sul, que são áreas alternativas de esporte, como campo de areia e áreas de práticas recreativas e eles desenvolvem competições esportivas, na parte de lazer, e também desenvolvem passeio ciclístico, festivais, eventos de lazer. Então, por exemplo, nessa concepção de lazer e daí então na parte da cultura entra também com esses eventos para fazer um complemento. Então, essa é a política de lazer que existe em Jaraguá do sul, hoje.

34- Muito voltada à prática de esporte?

Resposta- Muito voltada na prática de esporte.

35- Você teria uma justificativa disso? Como isso se deu? Eu percebo que há uma ligação

forte com a prática de esportes. Eu queria saber se você tem alguma explicação?

Resposta- Eu não sei se tem uma explicação lógica ou não, mas, por exemplo, eu poderia colocar até a questão de falta de outras opções, ou pelo esporte estar mais presente na sua escola, nas empresas onde os pais estão trabalhando. Porque se nós formos ver o número de centros recreativos nas empresas, eu não sei se no estado tem um número tão grande.

36- Toda a empresa tem o seu centro recreativo?

Resposta- Toda a empresa tem o seu centro recreativo.

37- O que é favorável à prática de esporte?

Resposta- Para a prática de esporte e também para outras atividades sociais.

38- Por exemplo, churrasco?

Resposta- Sim. O pessoal busca no esporte, nessa parte aí, um modo de extravasar.

39- Como é uma cidade industrial, as pessoas precisam, necessitam extravasar aquela atividade cotidiana de alguma forma e o esporte está sendo uma ótima solução.

Resposta- É, o esporte hoje está presente na área das empresas. Se a gente for ver aí a quantidade de pessoas que praticam uma vez por semana ou duas, mas é a maioria.

40-Tem ginástica aqui nas empresas também, não é?

Resposta- Sim. Então, tem esse trabalho. Eu não sei se é o mal hoje das cidades industriais, das cidades mais urbanas a falta de espaço para a prática. Então, as crianças se limitam a praticar, às vezes por falta de opção. Por exemplo, onde uma criança pode brincar com uma pipa, onde uma criança pode andar de bicicleta, ou com carrinhos?

41- Quer dizer é uma cidade pequena, mas ao mesmo tempo as crianças não têm esse espaço? Resposta- Não têm os espaços, por exemplo, se a gente for sair aqui do centro, para o interior, para a periferia, nós vamos ter outras realidades. Como a gente encontra no interior as novidades para elas são a cama elástica que você leva para a recreação, são a oficina de 
bolinhas, porque eles estão acostumados a brincar de correr nos morros, de tomar banho no rio, de subir em árvores.

42- Atividades bem mais interessantes que as bolinhas?

Resposta- Isso. Atividades bem mais interessantes, e que, então, o pessoal do interior querem brinquedos mais urbanos e os urbanos querem os do interior, a busca hoje na nossa sociedade está nessa linha.

43- Vocês elaboram os eventos, as atividades, eu queria saber se existe alguma ação dirigida para os operários ou para as crianças, ou para a idosos. Você fez uma monografia, estudou sobre lazer, sobre a questão da cultura alemã, não é? Existe essa elaboração ou não? Ou vai começando a elaborar os eventos de acordo com o que surge?

Resposta- A questão dos idosos, nós temos hoje na nossa Prefeitura, um departamento que é o centro de atendimento à terceira idade, onde tem mais de três mil idosos que participam de eventos rotineiramente. São eventos de lazer, eventos recreativos, eventos culturais, então tem todo um departamento de cultura especialmente preocupados com a prática dos idosos. E para as crianças a gente elabora então um calendário de acordo com as atividades deles, então nós temos uma série de atividades voltadas para as crianças, mas mais para escolares. Tanto no esporte, como na cultura e a educação e outras área afins, eles fazem essa parte. A questão dos empresários, as empresas geralmente se responsabilizam por essa parte de recreação, que é a parte que eu coloquei antes com as sociedades recreativas.

44- Cada empresa se preocupa com os seus operários, seus trabalhadores?

Resposta- Sim. E tem as entidades também aqui, Sesc, SESI que aqui em Jaraguá do Sul funciona bem e fazem essa linha. Então tem essa, digamos assim, hoje nós temos um leque muito grande de opções; eu acho até em questão de, voltando aos eventos, se a gente for pegar durante esse ano, nós tivemos muitos eventos voltados para a população. Tanto que na última semana, nós tivemos um evento, que é uma ação comunitária, realizado pela empresa "X", que juntou 10.000 pessoas no parque de eventos para uma série de atividades.

45- Eles promoveram?

Resposta- Isso. A empresa " $X$ ", promove e toda a comunidade participa, a Prefeitura, SESI, Sesc participam juntos e fazem as atividades.

46- Atividades de quê?

Resposta- Atividades recreativas, atividades culturais, shows e também atividades de corte de cabelo, é uma ação global, uma ação comunitária.

47- Atende várias dimensões da vida prática de cada um, de prática de esporte a cortar cabelo?

Resposta- Isso. A fazer documentos, práticas de saúde.

48- E essas coisas não são resolvidas no cotidiano? As pessoas não teriam isso normalmente? É uma cidade rica, não é? Todo mundo então vai cortar cabelo, tirar documento, não seria prática comum, habitual? Precisaria de um evento para fazer isso, qual é o sentido real desse evento?

Resposta- $O$ sentido, isso aí até (...) Nós temos uma cidade rica, mas também temos problemas sociais em Jaraguá.

49- Mas não se vê assim?

Resposta- Aparentemente não se vê, talvez o número seja reduzido e as pessoas estão sempre atendidas, mas alguém está atendendo essas pessoas, ou a Prefeitura, ou outros órgãos, está se dando apoio para essas pessoas. Então, tem um movimento muito grande. Às vezes as pessoas vão até por economia, vão lá e cortam o cabelo, com a questão de tempo, às vezes você se deslocar o seu tempo um dia na semana. Então, às vezes o pessoal utiliza isso, a 
pessoa corre lá para fazer a identidade e bater a foto, mas aqueles que trabalham aqui, eles não querem tirar o tempo deles "oh, eu tenho que ir lá".

50- E também é de graça?

Resposta- Isso.

51- E daí ele já economiza para comprar o carro?

Resposta- Isso, é uma média hoje de manhã até estava falando, para cada dois habitantes há um carro em Jaraguá.

52- Eu fiz entrevista com alguns operários e quase todos tinham carro. Então, realmente é um índice grande.

Resposta- Se a gente for (...), eu não sou Jaraguaense.

53- Você veio de onde?

Resposta- Eu vim de perto de Rio do Sul.

54- É italiano?

Resposta- Descendente de espanhol. A gente vê que aqui em Jaraguá o pessoal dá muito valor material.

55- Aos bens materiais.

Resposta - Aos bens materiais. O conhecimento isso fica (...)

56- Eu fiz vários levantamentos aqui na sua cidade e muitas pessoas que estão em postos de direção de muitas coisas aqui, são de fora. Você por exemplo, também é de fora.

Resposta- Sim.

57- Então, eu ainda não encontrei uma pessoa que nasceu aqui, só um. O restante de todas as pessoas que conversei eram pessoas de fora daqui, ou seja, parece que a direção da cidade, os postos de direção política de alguma coisa é de fora, não são da cidade, porém todos falam que aqui se preza muito pela obtenção dos bens materiais.

Resposta- Eu não sei se isso é bem da colonização, mas essa é uma característica.

58- Característica presente e forte, eu posso escrever isso na minha tese, que aqui existe essa preocupação?

Resposta- Isso.

59- Então o lazer como é que fica? Se o lazer é um componente que eu estou vendo como uma necessidade que entra no campo do não-material, então como é que a gente vai lidar com isso numa cidade em que as pessoas são educadas para ter bens materiais? E aí como é que vocês estão resolvendo?

Resposta- É uma grande dificuldade, por exemplo, aqui, quando nós entramos a dificuldade era levar o público para os eventos, porque a gente tinha que fazer propaganda, tinha que fazer cartaz, tinha que fazer panfleto, entregar, rádio.

60- Não existia o hábito de participar de eventos?

Resposta- Não existia.

61- Em quanto tempo isso mudou?

Resposta- Em que eu estou atuando, cinco, seis anos.

62- É recente?

Resposta- É recente. E o negócio é devido a miscigenação que teve, essa troca de informações, pessoas de fora. Antes se você saísse à noite aqui em Jaraguá do Sul, você não encontrava uma casa, um bar aberto. E hoje já tem. 
63- Quantos? Dois ou três?

Resposta- É. Antes você não encontrava restaurantes aos domingos, aos sábados para almoçar.

64- Era trabalhar. As indústrias aqui (...), a ... aqui têm trinta anos?

Resposta- Quarenta anos.

65- Mas assim, ou seja, esse povo até então, só trabalhava? Se você chegar com uma proposta de lazer para as pessoas que historicamente estão organizadas para trabalhar, deve ser realmente muito desafiador colocar em prática, não é?

Resposta- É bastante. Alguns até aliam o trabalho ao lazer. Até conversando com um senhor aqui, aquele que eu fiz uma entrevista com ele. Ele colocou que ele estava escrevendo um livro e que a ânsia dele para terminar aquele livro era muito grande. Então, no trabalho dele, ele estava se divertindo, desenvolvendo aquele trabalho. Ele me disse que ele é um pesquisador, um historiador, o prazer dele é entrar numa biblioteca, ou num arquivo $e$ procurar, ele não sente as horas passarem, não sente fome, não sente nada. Então aquilo satisfazia a necessidade dele de lazer. Então há essa confusão, muitos praticam na sua casa arrumando o jardim, podando árvores ou lavando carro, esse é o sábado e domingo de muitos aqui em Jaraguá.

66- E também nos meus dados eles disseram que eles se reúnem muito com a família? Resposta- Isso. Muitas reuniões familiares.

67- Fazem comida, isso acontece todo domingo. Então não precisam de restaurante aos domingos. É um hábito?

Resposta- Sim.

68- Porque foram muitos que disseram que eles curtiam fazer reunião de família para comer, para juntarem-se dia de domingo.

Resposta- É um hábito constante no final de semana o pessoal se reunir, os bens conhecidos. Porque você, por exemplo, que vem de fora, até que você entre num círculo desse é muito difícil. Hoje eu não sei, mas quando eu vim para Jaraguá, estou em Jaraguá há 12 anos, eu vim sozinho para cá. Foi muito difícil entrar na vida social.

69- E ao mesmo tempo a classe média daqui é formada por muita gente de fora, não é?

Resposta- Muita gente.

70- Tem o pessoal da empresa que pesquiso, muito engenheiro, é tudo de fora, Curitiba, São Paulo, Rio Grande do Sul.

Resposta- Profissionais liberais digamos, médicos, dentistas, advogados, engenheiros muita gente vem de fora.

71- Vocês estão dando essa explicação, esta seria a explicação das mudanças das práticas de lazer?

Resposta- $O$ pessoal, digamos assim, se habitou ao que tinha aqui e os que moravam aqui foram se habituando a novos hábitos. Hoje os mais jovens, talvez já tenham até outra formação em relação a questão de trabalho, a questão de lazer, a questão de bens, de adquirir ou não bens.

72- Comprar carro, comprar casa?

Resposta- Isso. Eu trabalhei muito tempo num colégio aqui e a grande ânsia dos alunos é terminar o ensino médio, o antigo $2^{\circ}$ grau para entrar no mercado de trabalho e muitos já entravam antes.

73- Na escolinha da empresa "X" não é?

Resposta- Durante o próprio estudo eles já estavam trabalhando e muitos já possuíam carro, nem tinham direito a carteira, mas já estavam comprando o seu carro. 
74- E compram o carro para passear ou para ter o carro?

Resposta- Olha, parece um culto, eu não sei se é só de Jaraguá ou do brasileiro, mas o pessoal aqui dá muita importância para isso.

75- E essa questão do desemprego, está alterando alguma coisa aqui, está existindo alguma coisa aqui que seja ressonância do desemprego? Por exemplo, pessoas nas ruas, gente desempregada com o tempo livre por falta de emprego?

Resposta- Não, hoje, se você tem uma especialização dificilmente você vai ficar sem emprego aqui em Jaraguá, se você tem uma especialização e quer trabalhar realmente. Agora, realmente para quem não tem o mínimo de formação está difícil a questão de trabalho. Até a gente acompanha todos os dados que chegam do Sine. Hoje a grande dificuldade para arrumar trabalho aqui em Jaraguá do Sul, são pessoas sem habilitação nenhuma, nem digamos, o ensino primário, ou o ensino médio. Agora se você tiver alguma especialização, você dificilmente fica sem trabalho aqui.

76- E qual seria, dá para dar um consenso sobre o trabalho, o trabalho aqui para a maioria das pessoas seria a questão principal, não é?

Resposta- Isto.

77- A centralidade aqui da vida das pessoas realmente é o trabalho?

Resposta- É voltada para o trabalho.

78- Ou para estudar, para arranjar emprego, a formação é toda exigida para o trabalho.

Resposta- Isso é verdade.

79- Justamente por conta disso, o meu interesse é o do lazer, como é que você vai tratar do lazer, numa cidade em que as pessoas são formadas para o trabalho?

Resposta- Quando eu comecei a trabalhar com lazer, com recreação, as pessoas comentam "tu não trabalha, tu brinca". Trabalhar, o conceito de trabalho aqui, ou você está numa empresa, ou você desenvolve uma atividade totalmente voltada outra coisa, você digamos se for para promover alguma coisa, ou trabalhar com o lazer, não é um trabalho, mas uma diversão.

80- Porque a concepção do trabalho, é trabalho produtivo numa indústria, saiu dali já não é trabalho.

Resposta- Até colegas meus de trabalho da Prefeitura dizem: é fácil, você está se divertindo, trabalha por brincadeira e coisas assim.

81- A questão é importante, enquanto na Europa está sendo uma temática super privilegiada aqui nós temos dificuldades para convencer as pessoas sobre a importância do lazer (...)

Resposta- Da importância do lazer. Aqui geralmente se tem uma discussão para fazer um feriadão, que cai na Sexta-feira; então o Prefeito quando decide emendar um feriadão ele é xingado a torto e a direito. Ás vezes eu pergunto porque que eu trabalho? O quê é qualidade de vida? Qualidade de vida é você ter direito ao trabalho, ter direito ao lazer, ter direito a saúde, a educação. Você trabalha para isso, você trabalha para poder ter as horas de descanso ou o final de semana ou as férias são boas porque você trabalhou e você tem direito a esse descanso. Mas, eu acho você renegar esse descanso ainda ...

82- Você está me dizendo que ao ter um feriadão as pessoas xingam, ficam descontentes; será que elas não estão sem formação para exercer o lazer. O lazer pode até incomodar?

Resposta- É verdade. Até porque aqui nós estamos muito próximos das cidades turísticas, cidades de praia, então o pessoal, mas aqui a gente também tem o outro lado da economia. Tem os hotéis no feriadão, que estão trabalhando para a diversão, tem as estradas... tem toda uma rede de serviços! 
83- Então, veja, o trabalho é bem interessante; o conceito de trabalho para eles é trabalho produtivo?

Resposta- Sim.

84- Então, se não for para gerar renda, ou gerar alguma relação de lucro, não é trabalho?

Resposta- Pois é. Então, assim se for pensar aqui em Jaraguá do Sul tem um feriadão é movimento para o hotel, é movimento para a lanchonete, é movimento para bares, para as casas noturnas, só que aí o pessoal pensa "mas as empresas pararam"ou a "cidade parou”.

85- Então, as pessoas mesmas, os trabalhadores das empresas, eles também têm essa concepção?

Resposta- Eu sei que tem porque geralmente, o cara que está na Prefeitura, quando decide isso, não é o Prefeito sozinho que decide o feriadão ou não (...)

86- Se no carnaval, no sábado de carnaval trabalha, na terça de carnaval se trabalha, eu imagino que é (...).

Resposta- É, então assim, são decisões difíceis a gente estava junto até com o Prefeito eles ficam numa sinuca: emendar ou não, dar ou não o feriado? Daí é aquilo que eu coloquei antes, o pessoal que vem de fora quer ir para sua praia preferem pelo feriadão, mas alguns empresários daqui e o comércio preferem que não tenha.

87- A festa principal é a Schützenfest, que é a festa do tiro que durante um ano inteiro eles se preparam?

Resposta- Isso.

88- É interessante porque para essa festa há uma organização durante o ano. Já esses eventos soltos é uma coisa mais de consumo. Concorda com o meu raciocínio?

Resposta- Sim.

89- Essa festa fica mais interessante porque ela tem durante o ano uma produção e eles se juntam durante o ano.

Resposta- É verdade. E até agora acontece a $13^{a}$ edição da Schützenfest antes as sociedades de tiro estavam se acabando. Eles não tinham mais um motivo para preservar e hoje se você vê aqui em Jaraguá do Sul você vai ver crianças participando das festas.

90- E esse interesse de permanecer sem festa, você percebe algum motivo?

Resposta- Sim.

91- Um interesse maior?

Resposta- Eu diria que (...)

92- A cultura predominante é alemã?

Resposta- Sim.

93- Quanto a origem tudo bem. Mas como é que está se dando hoje, com essas influências externas, com esse povo de fora trazendo novas influências, essa festa permanece com a cultura alemã? O que faz sustentá-la?

Resposta- Eu acho que hoje é a população em si, porque não só os alemães né, a festa se mantêm pela população.

94- Ou será que não é porque durante o ano eles têm o que fazer, com um objetivo final, como o carnaval, escola de samba? Quer dizer, gera também dinheiro, gera comércio e alemão como tem essa relação, será que (...)? Não pela festa, pela questão do lazer, mas pelo conjunto dos elementos que ela conjuga.

Resposta- Sim. e aqui assim, a grande maioria da população, por exemplo, a Schützenfest existe como um evento a mais, digamos assim, aqueles que não vivem na sociedade, que não tem a tradição alemã na sua casa, então ela está mais como um evento como está a Oktoberfest, como está a Fenarreco, as festas aqui em volta da região. 
95- E o espetáculo também, tem o lado do espetáculo?

Resposta- Isso, tem o lado do espetáculo, tem o lado para tomar, tem o lado de você ter uma noite inteira de festa ou a semana inteira de festa, então tem o (...). Para a grande maioria que hoje (...)

96- O significado não é só da cultura alemã?

Resposta- Não. Se nós fizermos um levantamento no ano passado eu acho que teve $100 \mathrm{mil}$ pessoas durante os sete dias de festa. E essas 90 mil pessoas não têm nada a ver com alemão e são meros participantes, que vão, consomem o seu chope e dançam e vão embora e aí digamos, não estão preocupados com essa questão de manter a tradição. Muitos nem sabem o porquê da Schützenfest, digamos que vão ... é bebida, festa, dança, comida, muitos não têm interesse de buscar como ela nasceu, o porquê, o que acontece antes.

97- E as principais atividades desenvolvidas por vocês aqui seriam a prática de esporte e esses eventos culturais?

Resposta- Eventos culturais e de lazer.

98- Existe a distinção entre a cultura e o lazer. O lazer como prática de esporte e cultura é prática do quê?

Resposta- A gente faz festivais de música com a participação de estudantes, com participantes de Jaraguá do Sul, a gente faz concurso de poesias.

99- E dão prêmios bons?

Resposta- Para a música sempre tem um incentivo bom, que são $R \$ 1.000,00$, digamos que é razoável para estudante. $R \$ 1.000,00$ para a campeã, $R \$ 700,00$ para o segundo e $R \$ 500,00$ para o terceiro. Nós sempre damos em dinheiro para a poesia também damos em dinheiro.

100- Tem poesia também?

Resposta- Tem festival de poesia. No último nós tivemos 205 inscritos, escolares. E também nós temos dança, são 1100 alunos que participam desse festival, é um número até razoável pelo número da população. A gente faz eventos assim muitos shows, digamos assim, eventos nessa parte. Hoje nós temos um centro cultural, o nosso teatro. Ele vai ter uma capacidade para 1.100 espectadores e com uma acústica muito boa e que vai ser uma das melhores casas 101- Você vem dizendo que é bem nova essa promoção cultural na cidade, não é?

Resposta- Sim.

102- E eu quero saber se foi de cima para baixo, quem foi que decidiu, por exemplo, construir o teatro? Se a maioria das pessoas têm a centralidade da vida no trabalho, mas de repente tem aquela construção do teatro, que é muito bonito, muito grande...será influência de Joinville que está bem perto daqui; o que seria? Ou por que as pessoas têm que ser incentivadas para participar, é o que está movendo essa política cultural de lazer?

Resposta- Antes as pessoas tinham a sua cultura, digamos assim, a ênfase nas atividades, mas sempre ... foi muito forte nessa preservação cultural.

103- Na doméstica, não é?

Resposta- Isso, na doméstica e a Scar, que é a Sociedade de Cultura Artística daqui, ela existe há 45 anos, 50 anos. Ela têm uma história muito grande em Jaraguá do Sul, só que sempre foi muito fechada e hoje a preocupação da Scar até com a construção do espaço cultural. Você tem que ter consumidor para aquilo ali. Não adianta você ter um espaço e não ter público, hoje a Scar - Sociedade de Cultura Artística, ela tem experiência de trabalhar numa cultura elitizada, é uma posição que eu tenho. E a Prefeitura em si, o órgão público, a gestão pública ela tem experiência de trabalhar com a massa e hoje nós estamos conseguindo uma junção entre a Sociedade de Cultura Artística e o setor público.

104- Porque os trabalhadores também têm um padrão de vida, um poder aquisitivo que dá para freqüentar esse espaço? 
Resposta- $O$ grande desafio daqui para a frente na área cultural e do lazer é desenvolver o hábito de você participar de eventos, de eventos, de shows, de teatro, tirar o pessoal de casa no final de semana.

105- Eu já estive aqui em vários finais de semana e a cidade parecia fantasma mesmo.

Resposta- Sim. A gente já está promovendo muita coisa realmente, mas....

106- E também não tem esquina, eu fiquei preocupada com isso, não tem como as pessoas se juntarem.

Resposta- Então, nós temos hoje, além desse desafio de criar os hábitos com essas pessoas. Eu acho que nós já estamos conseguindo através do estudantes, que é toda essa promoção que existe, eventos culturais...

107- Outro dia eu vim aqui num outro final de semana e não encontrei praticamente ninguém, em nenhum espaço público, nessas quadras. As quadras estavam todas, sem ninguém, nenhuma atividade e fechadas. Eu fiquei achando (...) será que tudo tem que ser planejado?

Não dá para juntar a turma e ir para a praça?

Resposta- É verdade. Sem um planejamento, você pode passar no final de semana na praça e você vai ver uma ou duas mães brincando com o filho no parque. Você para ter um evento tem que ter uma divulgação muito grande em cima dele e você têm que se preocupar em fazer o evento e levar o público. Muitas vezes a gente faz evento e temos que disponibilizar ônibus, por exemplo, para trazê-los. Nós já tivemos, isso também é questão nossa, é dever da Prefeitura se preocupar com o transporte das pessoas, não com pessoas que não tenham condições de pagar o dinheiro da passagem, mas de você conseguir levar público. Então, por exemplo, se você faz uma promoção num bairro, você tem que levar os bairros vizinhos para lá.

108- De graça?

Resposta- De graça. Não que as pessoas não tenham condições de pagar. Porque se aqui em Jaraguá do Sul a pessoa falar, eu não posso pagar $R \$ 1,00$ para o ônibus, ou ela está desempregada, não tem trabalho, não tem assim, essa grande carência.

109- Essa característica, a classe média daqui tem um poder aquisitivo que daria para consumir lazer?

Resposta- Isso. E daí uma outra questão que se poderia levantar, que eu não sei se essas pessoas não vão para os eventos sociais porque, por exemplo, é mais aberto ao público, por questões tipo: "ah, eu não vou lá porque lá é para o povão" ou "lá é um evento que não é para mim”. Se existe este preconceito, digamos assim, então ás vezes (...), até agora, nessa última sexta-feira teve a noite alemã aqui, que é um evento que o ingresso custa $R \$ 50,00$ por pessoa; o salão estava lotado. Além disso, de você se divertir, tem o lado da elite, do encontro da sociedade.

110- Existe aquela festa da cidade - a festa do tiro, essa é popular, porque essa é num parque de eventos e tem as festas também que são as privadas, da elite da cidade?

Resposta- E mesmo na festa popular a gente tem a divisão com a venda dos camarotes.

111- Desemprego, vocês acham que ainda não está (...)?

Resposta- Ele preocupa, mas ainda não (...). Teve épocas, por exemplo, que deu movimento de migração de outras cidades, estado e aí foi feito um trabalho para absorver Jaraguá do $\operatorname{Sul}(\ldots)$

112- E não deixaram mais ninguém entrar?

Resposta- É. Ele tinha esse mercado e hoje o mercado está restrito, assim como em todo o país. Hoje a pessoa sem especialização aqui, dificilmente ela vai conseguir algum trabalho e vai conseguir se manter na cidade, porque a cidade tem um custo de vida alto também.

113- Já elimina não é?

Resposta- Isso. 
114- E o alcoolismo não tem dados oficiais, mas existe?

Resposta- Existe.

115- Todo mundo sabe que aqui existe um grau elevado de alcoolismo,

Resposta- Por parte dos jovens, toda a festa é motivo para você ter o álcool, como motivo de festa.

116- O que orienta mais a política de gestão pública de lazer? Quais os elementos principais que vocês estão se orientando para essas atividades? Existe uma preocupação de desenvolver alguma coisa ou é só lazer de consumo, ou só de espetáculo sem um caráter educativo?

Resposta- $O$ caráter educativo eu acho que ele está mais voltado para as crianças e jovens, digamos assim e com o trabalho que é realizado com a terceira idade, com o Centro de Terceira Idade. Com o público adulto, eu poderia até confessar para você que é voltado para o lazer de consumo, proporcionar esse hábito de lazer. Mas eu acho que hoje a maior preocupação do poder público está com as crianças e jovens para que eles adquiram uma cultura.

117- Mas que tipo de cultura? Porque gera uma preocupação séria, pois a cultura daqui é essencialmente voltada e oriunda do trabalho, poderíamos sintetizar assim. Os adultos pertencem ao círculo produtivo e as crianças e jovens estão se formando a partir de que elementos? Nessa variação do trabalho, como é que inclui o lazer aí, de que forma, quais os elementos principais? Porque nessa formação se ele tem o hábito só de trabalhar, se é o trabalho que dá o sentido da vida, que você falou antes, se de repente a pessoa diz, "você não trabalha, você brinca, você se diverte". Então, se o seu trabalho não está ligado a produção material (do lucro) você não está trabalhando, como ficamos?

Resposta- Eu acho que hoje, o grande desafio realmente é o cara se voltar para a educação e a educação como um todo. Você educar essa criança ou esse jovem para que ele tenha consciência que ele precisa ter o lazer dele, mas ele também precisa ter conhecimento para adquirir um trabalho no mundo capitalista, a lógica dele qual é? Você educar para um todo, um ser completo.

118- É aquela questão que eu coloquei antes, o lazer atende a uma necessidade não material numa cidade que as pessoas só querem, só foram educadas para atender as suas necessidades materiais. E aí, como é que se resolve? Porque realmente é um desafio grande.

Resposta- É um desafio grande. E eu também não sei se essa é a maior preocupação dos dirigentes, digamos assim, não dos dirigentes, hoje o nosso prefeito, mas de toda a comunidade. Se existe uma preocupação. Por exemplo, eu tenho essa preocupação porque a minha formação é mais voltada para essa área, para a área do lazer. Agora, eu não posso dizer que essa preocupação dos empresários, que essa seja a preocupação de outras áreas, ou até mesmo das pessoas que hoje estão cursando uma faculdade. Porque se a gente for ver, a grande maioria busca na faculdade, eles buscam fazer a sua faculdade para ter um bom trabalho. Hoje a busca do conhecimento não é a busca para você ter conhecimento para você, mas sim um conhecimento que você possa estar dentro do mercado de trabalho. Eu acho que esse é o mal do mundo capitalista ou bem, não sei, buscando sempre tudo que tenha uma contra partida.

119- Nem teoricamente isso está muito claro, ainda.

Resposta- Não, hoje não. Até falando na linguagem dos escritores, dos autores, não tem uma relação, porque daí a teoria se perde. Então, eu te pergunto: do que você vai viver se você não trabalhar? Como é que você vai adquirir condições para você estudar?

120-Há que ter dinheiro. Quem vai pagar para você estudar, não é?

Resposta- Isso. Então ampliando a educação como um todo para você buscar o equilíbrio. Você não pode ter, por exemplo, você não pode ter só a visão trabalhista, ou só ter a visão da boa vida. Eu acho que tem que ter uma consciência do equilíbrio.

121- Mas aqui, poderíamos afirmar: só se trabalha. 
Resposta- Mais trabalha do que (...)

122- Se no cotidiano, eu diria que existem as festas esporádicas e habitualmente a centralidade é o trabalho.

Resposta- Tudo gira em torno do trabalho, por exemplo, final do ano, tem férias coletivas, a cidade pára, hoje em dias de festas de natal e reveillon você podia andar por aqui na avenida e você não via ninguém, a cidade parava literalmente, as festas são coletivas. As empresas determinam o ritmo da cidade e também foram essas empresas que construíram essa cidade, que levaram essa cidade a ter um patamar de vida que ela tem hoje.

123- Sem esquina não é? Isso eu não me conformo.

Resposta- Sem esquina é verdade.

124- É uma cidade em que você só passa por ela, a sensação interior é a de que é para passar não é para você ficar. É para ir para casa, é para ir trabalhar. A rua não o atrai, quer dizer, então todo mundo vai trabalhar, porque é vagabundo quem fica na rua. Quais seriam as maiores dificuldades para a prática de lazer agora, o que você apontaria?

Resposta- Hoje em dia apontaria (...), Jaraguá está carente de espaços.

125- Espaços públicos?

Resposta- Espaços públicos.

126- Aqui em Jaraguá me disseram que eles pagam, alugam as quadras.

Resposta- A gente tem carência de espaço para grandes eventos, é uma dificuldade nossa e também a outra dificuldade é desenvolver o hábito das pessoas para o lazer.

127- A mudar, não é?

Resposta- A mudar um pouquinho a sua conduta.

128- Você está ficando especialista em marketing?

Resposta- É. Tem que ter uma grande divulgação, mas, por exemplo, o nosso ginásio fica pequeno para o público, mas por quê? Porque geralmente, os pais, eu não sei se obrigam ou não, a ver os seus filhos dançarem. Eles vão não pelo espetáculo, mas eles vão lá porque o filho vai dançar. E aí geralmente você lota o ginásio. Mas você tem um argumento muito forte de convencimento. Por isso que eu digo, hoje, nós já conseguimos que as pessoas vão e prestigiem mais os eventos porque aos pouquinhos tem aquele grupo que vai formando $e$ começa a participar.

129- Das atividades práticas as esportivas são as mais efetivas. Você concorda que essa cultura da prática dos esportes é forte aqui, ela se explica por quê?

Resposta- Eu acho que ela abrange um número de recreativas que existe nas empresas, o poder público também tem um trabalho.

130- Eu conheço o pessoal do SESI e são muitos jogos, muitos campeonatos.

Resposta- $O$ ano todo tem eventos voltados para a prática do esporte e aí o feminino fica um pouquinho de lado.

131- As mulheres?

Resposta- As mulheres perdem um pouco porque é mais voltado para o futebol de salão ou de campo. $O$ ano passado, por exemplo, a gente pensou em organizar eventos para mulheres e a gente não teve adesão.

132- Interessante essa questão, eu vi na empresa que estou pesquisando, muitas mulheres trabalhando em postos de trabalho que antes era considerado masculino. Para trabalhar a mulher se iguala ao homem, mas aí quando eu perguntei do lazer para elas, elas praticamente não tinham lazer. Os homens faziam futebol e elas ficavam em casa. É assim mesmo?

Resposta- Na questão esportiva como eu estava colocando antes, para as mulheres é difícil porque elas têm pouco tempo. Porque no final de semana elas têm que cuidar do seu filho, ou cuidar da sua casa. 
133- Não mudou muito isso, o homem ainda fica (...)?

Resposta- Eu não sei. Mas eu acho que é um pouco de culpa não só dos homens, mas das mulheres também.

134- São machistas elas?

Resposta- É, e já educam os seus filhos para essa linha. A menina lava louça e o menino vai jogar bola. Então, tem esse lado ainda, então as mulheres casadas geralmente pára a prática desportiva, daí na parte cultural elas têm uma participação. Tem eventos que tem uma participação de mulheres muito grande, às vezes mais do que os homens, eu não sei se é porque podem levar os seus filhos.

135- Mas e a dança, os homens participam da dança aqui?

Resposta- Não, nas escolas não tem, que a gente tenha (...), tem até bastante meninos que participam na dança.

136- É interessante, a parte do esporte é masculina. E quando chega na dança, então os homens aqui é que estão mais avançados, porque eles fazem dança e as mulheres não jogam futebol.

Resposta- Jaraguá do Sul tem algumas características diferentes de outras cidades. Às vezes a gente fala que o pessoal é fechado, que não tem lazer, porque muitos só pensam no trabalho; se você for falar com a pessoa que é daqui, ele não têm esse conceito. Para eles, eles são certos, porque realmente tem que trabalhar para você ter uma vida digna e que tenha a sua cultura, então ela se difere nesses pontos, cada um é feliz com aquilo que está desenvolvendo.

137- A minha curiosidade é no campo dos alcoólatras. Então, as pessoas estão felizes, mas existem muitos alcoólatras. Então, será que isso não indica um certo vazio de humanidade na cidade, quer dizer, só trabalham, mas sempre vazios. Aí bebem para relaxar, não têm outra forma de se distanciar do trabalho, já que o trabalho é repetitivo, é aquela história que a gente já sabe.

Resposta- E nas reuniões discutem trabalho.

138- Reúnem-se e vão discutir trabalho. Até porque não têm outra coisa para discutir. A referência de análise da vida é o trabalho e aí tudo gira em torno dele.

Resposta- Eu não sei se você queria ver algumas fotos de eventos, de participação?

139- Poderia dar algumas para xerocar?

Resposta- Eu vou buscar para você então.

140- A cidade tem a predominância alemã, mas eu já notei vários postos de trabalho como eu lhe disse antes, com pessoas de fora e pessoas com uma raça ou negra, ou morena, brasileira e aí eu fico pensando: esses alemães não são preconceituosos de raça, o importante é que produza, seja competente no trabalho? Ou tem preconceito de raça, de cor, de algum tipo?

Resposta- É, eu nunca sofri preconceitos nenhum. Eu acho que realmente eles valorizam muito a pessoa que é interessada.

141- Competência no trabalho, isso é o que importa?

Resposta- Quem é competente. Isso. Por exemplo, assim, os valores, eles dão muita importância para os valores morais.

142- Moralidade, casado, família. Outra coisa que eu notei, são todos casados. Isso é da cultura, existe algum incentivo aqui para se casar ou é porque todo mundo gosta de se casar?

Resposta- Isso é porque realmente, eu acho que está imbricado na cidade, até quem vem de fora (...).

143- Em dois meses já arranja-se alguém para casar?

Resposta- É. Eu não sei se tem uma pressão para o lado dos homens ou para o lado das mulheres, mas eles não têm esse preconceito. Talvez até em épocas se existisse isso aí, mas até porque os alemães aqui e no Brasil todo eles sofreram muito com a Segunda Guerra, eles criaram uma certa resistência, porque eles foram muito discriminados. Eles mesmos foram 
perseguidos. Criou-se uma (...), mas eu acho que as gerações que vêm agora não trazem mais.

144- Porque eu encontrei aqui na empresa em que estou pesquisando muitos engenheiros, chefes negros. Para mim foi surpresa, porque imaginava como a cultura é alemã, eles iriam valorizar pessoas brancas, mas não vi isso.

Resposta- Ela se destaca por causa disso, ela valoriza muito a competência. Não importa a sua raça, não importa de onde você veio, tanto que o pai de um fundador é negro. E agora eu não sei se isso tem alguma relação ou não, de outras raças, não só o alemão, eu acho que eles valorizam o lado profissional.

145- Como você colocou aí sobre a questão moral; a pessoa tem que ser organizadinha, tudo direitinho?

Resposta- É, a pessoa tem que ser disciplinada, obediente. Todas as empresas prezam por isso hoje.

146- Tem promoções?

Resposta- Tem bastante promoções, tanto da área privada, quanto da área pública. .. Hoje o pessoal não pode reclamar que não tenha eventos, que não tenha atividade de lazer, têm bastante.

147- Dentro das próprias indústrias, elas se organizam?

Resposta- Elas se organizam.

148- Aqui é tudo organizado?

Resposta- É, o pessoal organiza bastante, é bem organizado. Até muitas atividades do Estado estão se voltando para Jaraguá do Sul devido a essa organização. Nós tivemos aqui o Festival de Formas Animadas, o Festival de Bonecos. E agora no final do ano vai ter o Festival Catarinense de Teatro.

149- Os grupos de lá vem para cá só para utilizar as instalações?

Resposta- Utilizar a instalação e fazer o encontro aqui.

150- E isso dá ibope político?

Resposta- A grande preocupação é que o jovem não beba, atividades que o jovem possa praticar, não só os jovens, mas as famílias. Nós somos motivadores, tipo o dia das mães, nesse dia, foi cobrado um quilo de alimentos não perecível. A gente conseguiu duas mil pessoas no nosso espaço.

151- E essas meninas são?

Resposta- Essas meninas são de Petrópolis, que vieram se apresentar, então a gente conseguiu um bom público.

152- Aí no caso vocês financiam a viagem?

Resposta- A gente financia a viagem.

153- Há que ter dinheiro para isso, há que ter orçamento.

Resposta- A Fundação Cultural tem um orçamento que é voltado para essas atividades. Então que é a valorização das etnias, que a gente tem que manter, manter não, incentivar as promoções dos italianos, dos alemães, dos húngaros, dos afro, dos afro-brasileiros, dos poloneses que são as etnias que formaram Jaraguá do Sul.

154- E vocês têm encontrado uma forma a estimular a não discriminação entre as etnias?

Resposta- Sim. Nós temos a Festa das Etnias onde todos se encontram e fazem a festa. Eles têm a sua concorrência, mas eu acho que para o lado saudável. Tem a noite italiana, festa italiana aqui, que é a segunda etnia em Jaraguá do Sul e o Festival da Canção, o qual nós tínhamos três mil jovens.

155- E todo o ano vocês estão fazendo?

Resposta- Todo o ano. Começou em 1997.

156- Porque aí eles se preparam, isso estimula. 
Resposta- Isso. Cada escola, porque vem da escola, cada escola faz o seu ... e que vem depois para participar.

157- Para estimular, é uma forma de participação na cultura (...)?

Resposta- Tem dança, tem poesia, tudo que a gente faz, a gente quer envolver com o esporte. 158- O problema do esporte é que são mais só os homens?

Resposta- É. Tem crianças também, no meu tempo também era assim, as meninas jogavam vôlei e os meninos futebol, mas depois que casa é mais difícil a mulher continuar na prática desportiva. E ela tem que ter vontade também.

159- E tem que modificar os hábitos dos homens também, aprender a fazer as tarefas domésticas, cozinhar também, lavar roupa também.

Resposta- E tem que ter essa troca.

160- Já revelaram algum talento?

Resposta- Já se destacaram alguns talentos que cantam em bandas.

161- A gestão pública também pode trabalhar com esses eventos porque dá ibope e eles estão fazendo bem para as pessoas e com pouco dinheiro relativamente.

Resposta- A gente não tem gastos astronômicos.

162- Tendo espaços também na cidade, o teatro já está pronto, não é?

Resposta- $O$ teatro já está terminado. E aqui também, o pessoal dá muito importância, aquilo que eu estava colocando antes, que o arquivo histórico se mantenha. Nós temos aqui o arquivo histórico que o pessoal vem procurar muito, a valorização da história da cidade. A gente tem essa preocupação muito grande.

163- E como você explicaria isso, o por quê dessa influência, dessa ênfase com a história? Por que isso não é em toda cidade, em todo município?.

Resposta- Eu acho que isso tem uma influência das próprias pessoas que começaram essa cidade, dos familiares, eles realmente cobram isso.

164- Uma cultura erudita no caso?

Resposta- Isso.

165- É uma formação que valoriza o arquivo histórico, valoriza a tradição. É uma formação que não é uma formação qualquer.

Resposta- É verdade. E Jaraguá do Sul, eu não sei, mas as outras cidades que eu conheço em termos de arquivo, nós temos uma documentação muito grande.

166- Sebos também, não é?

Resposta- Isso. E até depois eu quero te mostrar um filme, é muito lindo.

167- É da cidade?

Resposta- É da cidade, das indústrias de 1951 a 1964, depois eu vou te mostrar, é meio hora de filme.

168- Como começou?

Resposta- Como começou tudo. Isso aqui é a nossa praça. Então aqui, nós temos um espaço de um palco.

169- Concha acústica?

Resposta- É um palco, aqui nós temos um parquinho, o pessoal se aglomera para ver tudo. É pequeno, pode ver, mas aqui tinha umas 10.000 pessoas nesse show, mais ou menos. Veio para Jaraguá do Sul, Engenheiro do Hawai, Nenhum de Nós, Capital Inicial o ano passado no Especial de Natal.

170- E é de graça?

Resposta- Tudo de graça para o pessoal. Esse ano veio o Ira, o Sérgio Reis, vieram as Cantoras de Petrópolis... Eu acho que o Projeto mais social que nós temos é a Caravana da Alegria, a gente fica um dia todo num bairro fazendo atividades com as crianças.

171- A Sociedade de Cultura Artística.

Resposta- Seria bom tu conversar com alguém, tem pessoas que (...). 
172- Têm 45 anos, conhecem bem, toda essa cultura aqui.

Resposta- Conhece todo o movimento...A gente tenta trazer os mais (...)

173- Têm banda?

Resposta- A orquestra filarmônica, tem de várias escolas, tem fanfarra. ... Você encontra bastante coisa, choveu nesse dia a noite,...tinha um bolo gigante lá, o pessoal veio, mas hoje o pessoal está vindo para os eventos, elas não querem isso aí até... O pessoal está criando hábito.

174- Aqui tem uma miscigenação não é?

Resposta- Sim, é uma miscigenação, pode ver como já tem.

175- Brasileiro?

Resposta- Está mais miscigenado.

176- Eu tive na empresa " $\mathrm{X}$ " e muito engenheiro, muito chefe, muitos diretores negros, morenos.

Resposta- Em alguns quadros você encontra bastante o predomínio da raça germânica. 177- Não vi nada espontâneo, parece tudo planejado.

Resposta- É verdade. Ou tem que ser da iniciativa pública, ou tem que ser da iniciativa privada, ou do SESI e Sesc. Mas assim o que tem assim, também que o pessoal tem organizado é o encontro de motociclistas.

178- Há essa cultura também de moto?

Resposta- Tem. Então, muita gente vem para cá.

179- Os operários da empresa me disseram que curtem lazer fazendo motocross.

Resposta- Sim. Tem também a pista de vôo livre.

180- Tem parapente. Os esportes são todos de rico?.

Resposta- Refinados. E daí muito na periferia o pessoal tem o seu futebol, tem o seu baralho, a sua bocha... Esse aí foi o Sérgio Reis, a gente teve que fazer no pavilhão porque choveu no dia.

181- O sertanejo aqui é mais forte?

Resposta- É forte, o pessoal gosta...

182- Aqui é um bairro popular?

Resposta- É, um bairro de casas populares, pode ver, olha até a questão das casas populares como são bem bonitinhas.

183- As pessoas são exigentes?

Resposta- São, o pessoal é bem exigente. A gente tem que ter a preocupação de manter o nível daquilo que está fazendo, não deixar cair.

184- Aquela desorganização?

Resposta- Isso.

185- Tudo tem que ser organizado?

Resposta- Tudo tem que ser planejado. Por exemplo, esse evento nós estamos trabalhando nele com uma equipe muito grande, é muita coisa. Esse é o concurso de declamação, vai desde a criança até a terceira idade.

186- Muito interessante.

Resposta- São três dias, então a gente lança o livro.

187-E os livros são de autores daqui?

Resposta- São de livrarias, as livrarias e sebos daqui sempre participam e tem apoio.

188- E agora tem cinema no shopping, não é?

Resposta- Antes não tinha.

189- Eu achei engraçado isso, não tinha cinema até esses dias.

Resposta- Não tinha. Tinha cinema, fechou, ficou oito anos fechado e depois, agora só reabriu com o shopping. Se você for no shopping aqui, você faz uma análise muito interessante. 
190- Achei o shopping ótimo.

Resposta- Você vai ver o público que vai ali, o porquê, você faz uma análise interessante do porquê o pessoal vai ao shopping.

191- O que você acha?

Resposta- Um ponto de encontro poderia colocar assim.

192- E de consumo também, porque as pessoas vão se mostrar, por isso querem se arrumar e comer em restaurante. Shopping é para consumir....

Resposta- ... Tem assim, tem envolvimento do pessoal e também o pessoal da terceira idade, eles fazem eventos e a gente está sempre participando.

193- Existe corais aqui?

Resposta- Tem grupos de corais, tem doze corais. Tem diversidade, a vida de Jaraguá é muito rica, hoje o pessoal tem aquele lado mais fechado, mas é (...). Por exemplo, a noite italiana, tem a noite da "sopa... "que são os homens que fazem. Tem a noite brasileira, mas aí já não é realizada, pela associação. Eu acho que deveria ter aqui um pessoal (...) Tem show para todos os gostos.

194- Esses são daqui também?

Resposta- Esse aí é um grupo de (...), fazem sarau. A gente tem eventos que não estão aqui. Eu acho que vamos assistir ao filme, tu vai tirar bastante coisa interessante daquele filme ali. 195- Fazer a mudança de incluir a divisão de esportes à Secretaria de Saúde, eu acho que é nova no Brasil? Eu nunca vi.

Resposta- É, hoje o nosso organograma, da Prefeitura, está a Secretaria de Saúde, Esporte e Lazer e a Secretaria de Educação e Cultura. No anterior era Cultura, Esporte e Lazer. E o por que então perguntaram, o prefeito quando foi indagado do porque de colocar a Saúde, Esporte e Lazer junto, ele coloca que o esporte e o lazer está relacionado a saúde. Ele vê a saúde como completa, se você desenvolve o esporte e o lazer, você estará preocupado com a saúde preventiva. A doença você vai aplicar o remédio, mas aqui está preocupado com a prevenção. Então o esporte entra como prevenção de doença.

196- Orgânica no caso, é como eu coloquei antes, é a saúde mental, aí a cultura se separa e vai para uma instância que não seria a da biologia.

Resposta- É verdade. Eu não sei se tem um ganho ou não, porque até é o primeiro ano que está dessa maneira, mas então a gente vê mais o ... na estrutura da Prefeitura fazendo, ou desenvolvendo atividades de lazer para a comunidade, tanto na parte de cultura, quanto na parte de saúde, esporte e lazer e também na parte que tem desenvolvimento social, onde atende os idosos, onde atende as mães, com o clube de mães, com atividades voltadas para a atividade de lazer e recreativa.

197- Certo. Então o lazer fica concebido como esporte e a cultura é que inclui as práticas de teatro, de poesia, de show, de música? Está dividido assim?

Resposta- É verdade. Então a gente colocar a cultura como um meio de lazer, você assistir um teatro, você participar de um show, você (...), poesia, ou leitura, então a cultura se encaixaria como lazer. E do lado do esporte, a prática desportiva em si e a prática recreativa, nós poderíamos colocar assim.

198- Mas você trabalha com a cultura e é professor de educação física.

Resposta- Eu trabalho. Até porque em anos anteriores, eu trabalhava com a parte de lazer, dentro do esporte e tentava fazer essa conotação, então ficou muito assim, uma parte de eventos, dividida entre eventos culturais e eventos esportivos e de lazer.

199- Eles dividiram bem claro ficou bem nítida essa divisão, inclusive o esporte vai para a saúde.

Resposta- O esporte vai para a saúde. 
200- Isso também concorre para a divisão de orçamento financeiro?

Resposta- Sim. Nós temos a Fundação de Esporte que tem um orçamento específico e a Fundação Cultural, são duas Fundações que foram criadas em Jaraguá do Sul até para facilitar a operancia desses valores, desses orçamentos e para ter a gentes mais diretos ligados a parte (...), além da Secretaria de Educação e Cultura, e da Secretaria de Saúde, Esporte e Lazer, tem a Fundação de Esportes e a Fundação Cultural dentro dessas estruturas que também participam ...

201- Poder-se-ia fazer uma síntese do lazer de Jaraguá do Sul e da sua cultura: é diversificada, tem vários tipos de atividades, há várias instâncias organizativas, quer dizer, várias instituições que se preocupam com essa política pública de lazer além das próprias empresas em que se organizam internamente. É uma coisa bem interessante, porque a cidade é dirigida, sincronizada no trabalho produtivo tendo relação econômica e ao mesmo tempo está começando a existir uma preocupação com o Lazer. Eu não diria cotidianamente, mas esporadicamente,

Resposta- Tem uma preocupação grande que a população, que os trabalhadores, que as pessoas que vivem em Jaraguá do sul desenvolvam o hábito de lazer. Existe uma preocupação tanto por parte dos empresários, porque eles sabem que um trabalhador que tem a mente tranqüila, que consegue descansar, ele vai produzir mais na sua jornada de trabalho.

202- Então é visto, objetivamente, que é rendoso para o patrão.

Resposta - Sim, tem até um porquê, quando a gente retoma o assunto das recreativas que tem aqui, não é por vontade do patrão porque ele vai (...). Mas, a gente sabe que ele vai ter o retorno também. Um trabalhador, por exemplo, que consegue conciliar o seu trabalho com o seu lazer, com uma estada com a sua família, uma boa convivência, ele vai render muito mais no seu trabalho. E também do poder público tem essa preocupação de oferecer uma (...), uma cidade que se diz a primeira em qualidade de vida, ela não pode ser a primeira em qualidade de vida se não tem um bom desenvolvimento da parte do trabalho, da parte da educação, da parte do lazer.

203- É um dado que também corresponde à qualidade de vida?

Resposta- É um dado que também corresponde a esta qualidade tão propagada que Jaraguá do Sul tem. E que não é Jaraguá do Sul que está falando, são dados do IBGE que colocam Jaraguá do Sul em cima.

204- Uma cidade rica?

Resposta- Isto, uma renda per capta mensal.

205- E agora está se preocupando também com o desenvolvimento de bens culturais?

Resposta- Isto. Sempre foi muito forte na área da cultura, de preservação cultural, de você manter os seus valores, de ter um patrimônio documental, de ter um patrimônio arquitetônico muito forte, mas que talvez não propagasse isso muito, não tinha se propagada ainda essa sua cultura e que hoje com a vinda de pessoas de outras cidades, de outros estados, houve uma miscigenação e formou a Jaraguá do Sul que a gente começou a ver de dez anos para cá., que está começando para o estado e para o país.

206- E também com a repercussão das empresas que estão entrando no mundo, isso não influenciou a Jaraguá do Sul ampliar a sua cultura?

Resposta- É um dado muito interessante que a gente estava até discutindo, é que a maioria das empresas, em Jaraguá do Sul, foram iniciadas em Jaraguá por pessoas de Jaraguá do Sul, por empresários de Jaraguá do Sul, pelo homem Jaraguaense que vive em Jaraguá do Sul até hoje, essas pessoas que vem de países sempre são melhores. Apesar da ..., da Marisol, da Malwee, do ramo industrial, elas sempre chamadas como homens ou pessoas de marketing, de referências empresariais em todo o país. Então, em Jaraguá do Sul, não tem empresas nacionais que vieram se instalar aqui ou multinacionais que vieram apenas para 
montar aqui e explorar a cidade. Mas são empresas que nasceram em Jaraguá do Sul e os empresários têm a preocupação com a cidade e talvez é o que torne ela um diferencial.

207- Uma família grande?

Resposta- É verdade e todos se orgulham de dizer quando saem de Jaraguá do Sul, que moram em Jaraguá do Sul, que as empresas estão sediadas aqui e até mesmo, os trabalhadores, as pessoas que trabalham no comércio se orgulham muito da cidade de Jaraguá do Sul. O pessoal sai e diz Jaraguá do Sul é assim, nós temos esses indicadores.

208- Existe uma autoestima?

Resposta- Uma autoestima elevada na cidade.

209- A crise econômica não está atingindo?

Resposta- É. Sente-se a crise quando diminui a venda de motores, diminui a venda de vestuário, tem, mas não chega a afetar porque é bem diversificado. Tem um setor eletromecânico, tem um setor de vestuário, um setor de alimentação, um setor de comércio, então tem uma diversificação, se um trabalha mal, o outro compensa. Um exemplo é a crise energética que se abateu e as empresas de eletromecânica daqui faturaram mais porque criaram a divulgação do motor mais econômico, de transformadores de energia, de geradores de energia. Então, o pessoal até utiliza a crise para sobressair, os empresários daqui, as pessoas que criaram as empresas são pessoas muito criativas e que buscam sempre o crescimento.

210- Teria explicação de alguma forma para essa criatividade?

Resposta- Eu não sei se a colonização em si, se a gente for vê, não só o pessoal de Jaraguá, mas toda a região aqui de Joinville, Blumenau ou Santa Catarina, por ter essa presença européia muito forte. Nessa região de pessoas que vieram para cá, buscando perspectivas novas de vida, que passaram muita dificuldade, que tiveram que entrar em terras impróprias, matas fechadas para construir, fizeram o seu trabalho, buscar tudo, porque você imagina, você vem de um outro mundo que a sua comida é diferente, você pensa diferente, você tem que entrar num novo continente, você tem que produzir, você tem que cuidado da sua saúde, se você ficar doente, você tem que fazer o seu remédio. Então, tiveram todas essas dificuldades, superaram e se deram bem.

211- Criaram capacidade de resolver qualquer problema. Criaram-se pessoas mais criativas, solução de problemas é com essas pessoas mesmo não é?

Resposta- Isso. Então, por exemplo, esses pais, ou avós, ou bisavós, foram passando de geração em geração e é isso que ficou.

212- A gente percebe pessoas com autoestima, criativas e sérias no que estão fazendo. Eu não sei se está sendo real essa análise, mas vimos isso com as pessoas que conversamos. São todas pessoas muito presentes no que estão fazendo, fazem as coisas por gosto mesmo.

Resposta- É, se entregam, por exemplo, se você tem algum desafio em Jaraguá do Sul para organizar alguma coisa, o pessoal entra para fazer bem feito e quer sempre buscar o melhor.

213- E o retorno econômico existe, o salário é adequado?

Resposta- Aqui tem um bom nível salarial, poderia ser até melhor, mas a nível de Brasil, eu acho que está muito bom.

214- Então para finalizar você diria o quê do lazer de Jaraguá do Sul? Quais são os seus próximos desafios?

Resposta- É aquilo que eu havia colocado, a busca do equilíbrio. Você se envolver no seu trabalho, mas também se preocupar com o lado da diversão, do lazer. Não importa como você vê esse lazer, com uma leitura, ou você cultivar um jardim, ou você buscar viagens, mas que você tenha na sua vida sempre espaços para você, para a sua família, para os seus amigos, que consiga esses espaços. Não só ter o trabalho em primeiro lugar, o trabalho faz parte da vida, no nosso mundo capitalista mas que a gente consiga nesse trabalho um espaço para viver. 
215- Aqui, sindicato dos trabalhadores, essas questões, vamos dizer, do outro lado do patrão, eu não vi em nenhum momento, nenhuma forma de organização desse tipo, existe isso aqui? Resposta- Mas existe. Existe o Sindicato do Vestuário, o Sindicato de Eletro Mecânica, existe o Sindicato dos Servidores Públicos e o pessoal protesta, o pessoal luta pelos seus direitos também. Tem assim, uma imposição até forte nessa área.

216- Existem lideranças?

Resposta- Existem lideranças. Só que as manifestações são diferentes, o pessoal dificilmente sai para a rua para contestar, geralmente é em negociações com os patrões, é sentado para conversar, então tem o lado representativo do trabalhador, do operário, mas dificilmente ele (...). se a gente for citar alguma greve, alguma manifestação, há de se contar nos dedos, foram muito poucas. E até quando há greves a nível nacional, foram poucas que o pessoal de Jaraguá do Sul entrou, que participou. Até a nível de professores, por exemplo, que fazem muitas greves, aqui para conseguir mobilização o sindicato tem que batalhar, tem que ter um argumento muito forte para ter paralisação. Mas, tem sindicatos fortes aqui em Jaraguá.

217- Mas sempre caminhando para outras vias de reivindicações?

Resposta- Via de greve, faz muito tempo mesmo, só em último tempo mesmo.

218- Você não se lembra de quando aconteceu?

Resposta- Eu não lembro quando foi a última, até posso estar mal informado. Mas para discutir assim eu não conseguiria colocar.

Está bem. Obrigada por toda a sua atenção! 


\section{ANEXO 06 \\ ENTREVISTA COM UM TRABALHADOR DA EMPRESA SELECIONADA}

1- Você não precisa ter nenhuma dúvida, os trabalhadores que entrevistei não são identificados. Há uma questão que eu perguntei antes para você. Eles colocaram que lá, na fábrica "X", a maioria disse gostar mesmo era de jogar futebol como atividade de lazer. Eu não encontrei em Jaraguá do Sul, nos finais de semana em que estive aqui, nenhum deles jogando futebol.

Resposta- Você entrevistou o pessoal do primeiro turno, do segundo?

2- Eu entrevistei do primeiro turno e do segundo turno.

Resposta- Tem uma questão, vamos supor, final de semana o pessoal fica com a família realmente, é o que eu vejo, ou entre famílias. Um grupo faz um jantar, almoço, mas o futebol, a maioria joga durante a semana.

3- Eu poderia afirmar na pesquisa que o futebol entra num tempo cronometrado, fora do trabalho, mas é um tempo cronometrado, um tempo trabalhado, planejado (...)

Resposta- Toda quarta-feira tem jogo.

4- Tem jogo e pronto, é só aquilo e se torna uma rotina também?

Resposta- Até porque as quadras são alugadas, por exemplo, nós temos quadra lá no sindicato de janeiro até metade de abril, depois ela tem que ser renovada, talvez nós vamos conseguir.

5- Qual sindicato você está falando?

Resposta- Dos metalúrgicos.

6- É outro dado também que eu percebi, não se fala em sindicato.

Resposta - Muito pouco.

7- Não há essa cultura de organização enquanto classes, dos operários?

Resposta- Talvez porque a (...) se manteve mais familiar. A questão do sindicato não foi tão necessária.

8- Para os trabalhadores?

Resposta- Exatamente. Agora sim, está começando.

9- E por que você acha que agora está começando?

Resposta - Talvez pelo tamanho da empresa.

10- Está ficando muito grande e os problemas estão acontecendo?

Entrevista- É. Eu até não vejo porque a ... é uma empresa muito boa, a gente sempre chama de mãe ... .

11- Os operários, os trabalhadores?

Resposta- É. Porque vamos supor, você pode entrar com quatorze anos na ... , na escolinha, é o meu caso, inclusive. Tem muita gente dentro da ... que está trabalhando, trabalha até hoje, alguns saem vão para outras empresas. Ficam três anos na escolinha ganhando três, quatro salários mínimos, um salário mínimo.

12- Três salários mínimos?

Resposta- Três quartos de salário mínimo no primeiro ano. 
13- Estudando na escolinha?

Resposta- Estudando, só estudando, meio período. Aí depois, mais um ano tu avança no estágio, depois faz mecânica, depois faz eletricidade, depois faz eletrônica, e aí você é ... eu fui em 1981. Aí faz o... e tu vai ganhando mais um pouquinho, só que tem médico, dentista, almoço, vira um empregado normal, só que você está estudando.

14- Vi naquele manual que eles cobram o almoço e descontam no salário. Eles fornecem lanche, além do almoço?

Resposta- Se eu não me engano é $R \$ 10,00$ por mês.

15-Então, você vê que as pessoas se sentem protegidas pela empresa, você se sente protegido pela empresa?

Resposta- É. A (...) nunca foi de dar aumento abaixo da inflação, ou pelo menos na inflação, nunca deixou de..., tem a divisão de lucros.

16- O repasse é feito em duas vezes?

Resposta- É a cada seis meses no caso. O ano passado deu dois salários, esse ano deu três salários.

17- Ela recebe mais de um salário de seis em seis meses?

Resposta- O salário que a pessoa recebe.

18- Ela recebe mais um salário em seis meses. É mais que o $13^{\circ}$, além do $13^{\circ}$ ?

Resposta $-14^{\circ}$ e $16^{\circ}$.

19- Correspondente ao que a pessoa recebe?

Resposta- Exatamente.

20- É a divisão dos lucros?

Resposta- Isso.

21- Então com isso as pessoas ficam satisfeitas e não têm por que lutar?

Resposta- É.

22- Então qual é o maior elogio que você daria à empresa em que você trabalha?

Resposta- Solidez.

23- Segurança, seria isso?

Resposta- É, uma empresa bem sólida. Teve as suas crises, teve até greve com o sindicato, mas mesmo assim, foi crescendo, crescendo.

24- Qual foi o motivo da greve desta época? Que época foi essa?

Resposta- Época de redução de jornada, da crise.

25- Daquela crise que eles colocaram (...), mais ou menos em 1980, que eles queriam reduzir a jornada ganhando menos mas evitando demissões, não foi isso? Eu li no livro deles. E aí houve greve?

Resposta- Aí houve greve.

26- Organização? E como existe greve, sendo que o sindicato não é organizado?

Resposta- Teve a participação do sindicato.

27 - As pessoas uniram-se nesse momento?

Resposta- Tem a reunião do sindicato, para ver o dissídio no começo do ano.

28- Possuem um sindicato organizado?

Resposta- Tem. Mas não é radical como em São Paulo, a CUT, não é assim. 
29- Aqui se negocia, como?

Resposta- Aqui negocia.

30- Como é aqui?

Resposta- Aqui como naquela época, eu não sei se parou 100\%, eu, inclusive, trabalhei. Eu, na minha visão, vejo que o sindicato não é radical, não é aquele: não dá aumento então ninguém trabalha mais. Negocia, vai e volta e conversa um pouco, faz reunião.

31- Mas esse sindicato tem força para enfrentar uma ... ?

Resposta- Eu acredito que se houver necessidade, eu acredito que sim.

32- Se houver necessidade, eles se juntam?

Resposta- Isso.

33- Não se juntam habitualmente por que não precisam? É essa a sua análise?

Resposta - É. Se precisar se une e todo mundo vai.

34- Não se submete não?

Resposta- Não. Não é assim tão fácil. É que vamos supor, o pensamento da ... já é defender o lado humano, não só da máquina, então já ....

35- E como é que você vê essa proteção do lado humano na prática, como é que acontece isso?

Resposta - Tem médico, tem dentista, almoço, aquela revisão periódica.

36- Revisão de saúde?

Resposta- Revisão de saúde, os exames, tudo, os raio $x$, pulmão. Eu trabalho na fundição, então os eletricistas sobem em escada tem que fazer exame da cabeça, como é? Encefalograma é uma coisa assim. Então tudo isso é feito, acompanhamento.

37- E se a pessoa estiver doente?

Resposta- É tratado. Removido, ou trocada de setor, tem pessoas que tiveram problemas de pulmão e foram transferidas da função.

38- Mas não foram demitidas, nem prejudicadas por causa disso não?

Resposta - Não.

39- Vocês vêem que há isso na prática.

Resposta- Existe isso na prática.

40- Realmente eles não eliminam a pessoa?

Resposta- Não, não.

41- Eles tratam e tentam reinserir?

Resposta- É. Há talvez casos que vamos supor, a pessoa fica revoltada por causa disso, aí é contra, quer ir contra a empresa, ela não se ajuda, aí também já complica.

42- Da fábrica "X", você lembra? Há aquele galpão, onde tem a rebobinagem, tem várias seções dentro daquele galpão, com várias atividades.

Resposta- Usinagem de tampas, usinagem de carcaça, usinagem de eixo, a rebobinagem, a montagem e tem a área de testes também, os motores são todos testados.

43- Na fábrica "X" não?

Resposta- Eu não sei, faz pouco tempo que eu fui transferido para a fundição, então agora já mudou um monte de coisa lá. Mas se eu não me engano tem o teste.

44- Pois é, porque eu vi todas aquelas sessões ali dentro. Aquele monte de gente trabalhando, mas eles não tem tempo para conversar nem com o colega ao lado, não é?

Resposta- É, a produção é difícil. 
45- É intensa.

Resposta- Até consegue conversar, mas alguns (...)

46- Até porque o barulho que existe lá dentro já dificulta?

Resposta- Tem que ficar gritando.

47- Você faz ginástica?

Resposta- Não.

48- Na sua sessão tem?

Resposta- Não.

49- Qual é a sua sessão?

Resposta- Eu estou trabalho agora na fundição de Guaramirim.

50- E porque lá não tem ainda?

Resposta- Não sei.

51 - E no caso você se organizou no setor da escola, a sua formação foi na escolinha da (...)? Resposta - Fiquei lá três anos, trabalhei aqui na manutenção da fábrica II, dois, ... é dois, é três, é quatro, isso é uma média de formação, na fábrica $V$, fundição, na verdade ali é considerado parte do pavilhão II, então ali fazia manutenção de todas as fábricas. Em 1991, surgiu essa oportunidade para começar na fundição nova, inclusive em 1991/92 quando foi inaugurada era a mais moderna da América Latina, hoje não é mais. Aí desde lá, eu estou trabalhando aqui.

52- Qual seria a média salarial, porque na (...), eu notei que as pessoas têm casa própria, elas possuem automóvel, bens de consumo, os bens materiais de longa duração. Eles têm uma boa renda, não é?

Resposta- Eles têm uma média assim, normalmente o casal trabalha, então a renda dobra. E o pessoal de Jaraguá, hoje em dia já não é tão natural. Eu sou de Jaraguá, mas a minha esposa não é, é do Rio Grande. Mas eu conheço muita gente que é de fora de Jaraguá e pouca gente que é de Jaraguá, vem muita gente de fora, do Paraná, do Rio Grande, Cascavel e aí eles pensam mais em construir uma casa, em comprar um carro e acabam esquecendo da viagem, do lazer, etc, para fora da cidade, talvez por causa disso, eles acabam comprando as coisas, economizam, economizam.

53- Então existe um padrão salarial bom, o Sr diria que é de $\mathrm{R} \$ 1.000,00$ a $\mathrm{R} \$ 3.000,00$ mais ou menos uma média?

Resposta- Não, é mais baixo.

54- De R $\$ 500,00$ a R $\$ 1.500,00 ?$

Resposta- Não, a uns $R \$ 2.500,00$, tem chefe, tem engenheiro.

55- Há uma variedade, não é? Mas ficaria uma faixa entre $\mathrm{R} \$ 500,00$ e R $\$ 2.500,00$ ?

Resposta- Isso. Fora engenheiro.

56- Sim, fora o $14^{\circ}, 15^{\circ}$ ?

Resposta- Isso.

57- Mas também, quer dizer, no Brasil é uma faixa salarial boa e aí a pessoa se concentra na vida só para economizar o dinheiro para comprar o carro, a casa. Esse é o projeto de vida das pessoas?

Resposta- Isso, mais ou menos.

58- O Sr vê esse comportamento com os seus colegas?

Resposta- É isso que eu vejo acontecer dentro da produção. Eu falo com uma pessoa, tu já foi para o Nordeste? Não, nunca fui. Mas tu tem carro? Ah, tenho. 
59- A prioridade realmente são a casa e o carro?

Resposta- $E$.

60- E você acha que esse motivo é uma cultura da cidade, dá mais status, qual seria a preocupação?

Resposta- Talvez, por não ter aquela preocupação de estar sempre com aluguel (...), se eu morasse de aluguel, eu estaria sempre incomodado, nunca estou morando no que é meu, talvez, este lado seja diferente. Como o povo foi se misturando a cultura da cidade, cria isso um pouco.

61- A preocupação de não gastar o dinheiro numa coisa que não é sua?...

Resposta- Exatamente.

62- E você acha que a quantidade de horas que você trabalha, qual é a sua avaliação, muita, pouca, normal?

Resposta- Eu acho que é normal.

63- E por que você acha que a (...) cresceu tanto e ficou tão rica?

Resposta - Talvez o ramo, tecnologia, administração, muito boa administração a da (...) . A gente vê que tem muitas empresas que tem desperdício ou negócios errados. A (...) não, ela sempre faz a pesquisa, tu quer comprar uma coisa maior na ..., vamos supor, um valor de $R \$ 1.500,00, R \$ 2.000,00$, tem que passar por uma comissão, tem que ser julgado, tem que justificar a compra. Então tem várias coisas que faz a programação.

64- Isso é o que dá certo?

Resposta- É, isso é o que dá certo.

65- Isso é uma tecnologia. Há uma diversidade há um galpão daqueles que existe tecnicamente máquinas desenvolvidas, mas tem outros, lá na fábrica ... eu só vi uma máquina com computador, agora o restante, a rebobinagem (...)

Resposta- Há quanto tempo você foi?

66- Eu fui agora, tem três meses.

Resposta- É naquela fábrica é muito grande o motor, então as máquinas tem que ser muito grande. Eu não sei se você teve oportunidade de entrar na fábrica V ou na fábrica II?

67- Não, na V não, mas na IV eu fui.

Resposta- Na IV também os motores são grandes, mas já tem mais tecnologia, na fábrica II então, é bastante tecnologia, tem aqueles motorzinhos pequenos, tudo automático e a fábrica $V$ é a mais automatizada de todas.

68- E essas pessoas que trabalhavam ali, no momento em que eles colocam uma nova tecnologia, o que acontece com elas?

Resposta- Tem que estudar.

69- Eles incentivam isso?

Entrevista- Incentivam.

70- Não pode ficar atrasado tecnicamente?

Resposta- Vamos dizer, eu tenho curso de técnico elétrico mecânico no $2^{o}$ grau, depois fiz o curso de técnico eletrônico e aí agora, fazem dois anos terminei o curso de técnico de informática pela visão da concorrência. Quer dizer, tem que conhecer, tem que aprender uma coisa nova, então é a necessidade, tem que aprender.

71- Eles deixam claro para os seus colaboradores, como eles falam, que é preciso que a pessoa se atualize? 
Resposta- Isso.

72- Ela não pode ficar com aquela formação só adquirida na escolinha, deve sempre estar estudando?

Resposta- Sempre estar estudando.

73- E isso não forma também uma compreensão mais crítica do mundo? Quanto mais a pessoa estuda, mais ela se forma, mais ela vai querer um padrão de vida com mais qualidade, ou não?

Resposta- Também tem esse lado, quanto mais tu estuda, mais tu vai ganhando um diploma, ou vai avançando um nível mais, tu vai ganhando, então tu acaba chegando num nível maior.

74- Quer dizer, lá há um incentivo para você estudar e tem uma repercussão material, o salário altera? Há um incentivo realmente concreto, se você estuda, você vai ganhar mais?

Resposta- Na maioria dos casos sim.

75- E você nunca pensou em diminuir as suas horas de trabalho?

Resposta- Não, acaba acostumando. Inclusive a ... trabalhava segundas, quartas e sábados $e$ foi aumentado as horas durante a semana e uma parte foi diminuída e o sábado não se trabalha mais.

76- Esse ano, porque o ano passado trabalhava..

Resposta- Não, é porque tu deve ter pego alguma recuperação de hora, alguma coisa assim.

77- Porque eu peguei alguns sábados trabalhando.

Resposta- Eu acho que tu pegou aquela época que estava bem atrasada a produção da fábrica ....

78- Quando precisa, se trabalha?

Resposta- Se trabalha.

79- Aumentaram as horas nos dias da semana para não trabalharem no sábado?

Resposta- É.

80- Nos dias que eu vi, por coincidência, foram os que se precisaram trabalhar. Mas eu soube que esse ano só houve teve quinze dias de férias. Por que precisava de produção?

Resposta- Exatamente, aumentar a produção.

81- Ninguém ganhou mais de quinze dias de férias?

Resposta- Teve alguns setores que sim. Alguns setores ganharam, alguns setores não ganharam, como na manutenção alguns ganharam. Mas tem o outro lado, muita gente está de férias agora...

82- Mas, esse final de ano, eu soube que eles só tiveram férias no Natal e Ano Novo. O resto do verão eles trabalharam. O Sr confirma que é verdadeiro esse dado?

Resposta- É, não todos os setores, a maioria.

83- E como é que os colaboradores vêem isso? Eles se conformam?

Resposta- Tem que se conformar.

84- Por que eles têm que se conformar?

Resposta- $O$ emprego é necessário.

85- Você viveria sem trabalhar?

Resposta- Não.

86- Por quê?

Resposta-Porque se depende. 
87- A gente trabalha na verdade por que precisa, não é?

Resposta- Eu gosto do meu serviço, mas se eu pudesse ficar em casa, ganhando dinheiro sem fazer nada, eu ficava em casa.

88- Ou fazendo outra coisa?

Resposta- Fazendo outra coisa.

89- E que outra coisa você gostaria de fazer na vida que não faz?

Resposta- Eu me considero realizado, eu gosto da área em que eu trabalho.

90- E de lazer, o que você faz?

Resposta- De lazer, toda a semana tem futebol de salão.

91- Esse da semana?

Resposta- $E$.

92- Vocês pagam a quadra?

Resposta $\quad$ - Não, é só dar o nome para o sindicato.

93- O sindicato tem quadra?

Resposta- Tem quadra. Inclusive em Jaraguá deve ter mais de trinta quadras cobertas.

94- A maioria das pessoas que entrevistei falaram que essas quadras são pagas, que têm que alugar, não são quadras públicas?

Resposta- Não. A Marisol tem uma quadra para ela, então quem trabalha na Marisol não precisa pagar. Quem estuda no São Luiz, que é o colégio tem quadra, então deve conseguir quadra lá. Então todo mundo acaba tendo uma quadra para jogar futebol.

95- Se não houver essa ligação institucional tem que pagar? Vaga pública, ginásio público?

Resposta- Tem que pagar.

96- O seu turno de trabalho qual é?

Resposta- Eu trabalho no primeiro turno.

97- É o de 4:30h?

Resposta - É o de 04.42 até as 02:00H.

98 - E no caso a sua vida fica muito alterada com esse turno em relação as demais relações da cidade?

Resposta- Vamos dizer, quando eu fiz o curso técnico em Blumenau, eu fui técnico em eletrônica, trabalhava das 05:00 até 01:30, ia para casa, dava uma dormida, 05:00H pegava o ônibus, ia para Blumenau, voltava 00:00H. Naquela época eu só via o meu pai e a minha mãe no final de semana, durante a semana não tinha. Eles também trabalhavam fora, quando eu voltava, eles estavam dormindo, quando eu levantava eles estavam dormindo, quer dizer, a gente não se falava, então esse lado é complicado.

99- Você fica sem se relacionar com as pessoas afetivamente e aí só resta o domingo?

Resposta- Só resta o sábado e domingo.

100- E você tinha falado antes que o hábito aqui maior de atividades de lazer é o encontro com a família?

Resposta- $E^{\text {. }}$

101- Seria assim, no geral, no cotidiano, é o encontro com a família no domingo e durante a semana o homem vai jogar e eu pergunto as mulheres também estão indo?

Resposta- Estão indo, também têm esporte.

102- Mas é bem pouco representativo? 
Resposta- Também aqui como lá, uma cidade que é perto das praias, você vai muito em época de temporada para a praia.

103- No verão?

Resposta- No verão.

104- Isso no domingo?

Resposta- Não, vai sexta à noite e volta domingo a noite.

105- Eles me falaram que gostavam muito de praia. Isso é um hábito também?

Resposta- Isso é um hábito.

106- E as festas daqui?

Resposta- As festas (...), no carnaval não tem.

107- Eu já soube, inclusive, que trabalham no carnaval.

Resposta- Sempre foi uma revolta até porque, tu olha na televisão, São Paulo parou segunda, terça, sexta e aqui nós trabalhamos e aí vem o baile de carnaval, tu tem que trabalhar. Acabou no fim das contas todo mundo saber e não participar (...).

108- E a Schützenfest?

Resposta- Essa é mais tradicional, aí se sacrifica mesmo, aí todo mundo não quer saber se vai trabalhar com sono ou não vai.

109- E o que você pensa do seu trabalho?

Resposta- Em que sentido?

110- No sentido de auto-realização humana?

Resposta - Eu gosto, eu me sinto realizado. O trabalho de manutenção eletroeletrônica, ela não ..., cada defeito é um caso diferente e acaba mexendo com máquinas e pessoas. Muitas vezes pode ser que a máquina estragou, mas pode ser que foi mal operada, então tu tem que causa um ensinamento, tu tem que conhecer todas as máquinas, tu acaba tendo que conhecer mais do que os próprios operadores, às vezes, talvez, eles queiram te enganar para ficarem parados.

111- Isso nas fábricas?

Entrevistado- Na fundição, ... na época em que eu trabalhava na fábrica II, eu via acontecer isso.

112- Mas é muito cansativo o trabalho ali, aí a pessoa pára porque está cansada mesmo. Você não concorda?

Resposta- Tem dias que acontece alguma coisa com a família em casa, vem aborrecida, não quer fazer nada, um dia como terça-feira é insuportável.

113- Muito calor, não é?

Resposta- Então numa fundição, do lado do forno é terrível.

114- E qual é a diferença que você colocaria entre trabalho e lazer?

Resposta- Trabalho é obrigatório, lazer não.

115- Lazer, você faz o que quiser?

Resposta- $O$ que quiser, se você não quiser $i r, . .$. o esporte coletivo sempre vai ter gente cobrando.

116- E você, como é que você vê o seu corpo?

Resposta- $O$ meu ombro poderia ser um pouco mais largo, e eu acho que estou num peso bom assim. 
117- Porque há uma preocupação na (...) com essa questão da saúde, do corpo. O Sr acha que é uma cobrança de alguma forma, de um tipo de corpo, modelo de corpo?

Resposta- Eu não sei te dizer.

118- Não percebe isso?

Resposta- Eu não percebo, lógico ... engorda de repente, casou, aí os dois ficam gordos.

119- Por que todo homem que casa, engorda? Você tem uma explicação para isso?

Resposta- Talvez, comida regular, você é solteiro, vai na festa, não janta ou no final de semana para a praia, vai pescar, aí come peixe, futebol, você pode ficar mais, esporte, vai pescar longe, caminhada e hoje em dia não.

120- É uma vida mais regrada?

Resposta- Digamos aquela festa que tu ia a noite não existe mais.

121- Você vê algum grande problema em Jaraguá do Sul? O que você acha de Jaraguá do Sul?

Resposta- A poluição não deixa de ser um problema. Eu estou indignado com os rios, eu gosto muito de pescar...

122- Você tem medo do desemprego?

Resposta- $O$ meu cargo, vamos dizer, o que eu faço, eu teria o emprego do mesmo que faria instalação numa casa residencial.

123- A sua profissão daria conta de você se sustentar, não passar fome?

Resposta- Isso.

124- Eu vi poucas esquinas, poucas praças e pequenas. As pessoas não se juntam na rua para conversar?

Resposta - Aos domingos, antigamente eu não via isso, agora fazem uns cinco anos para cá, tem mais jovens lá, na Prefeitura, antiga Prefeitura...

125- É ali onde está o museu?

Resposta- Ali fica bastante gente na rua, tomando cerveja ou conversando.

126- É justamente o único espaço que eu vejo maiorzinho da cidade onde se pode encontrar gente. Confirma-se que há falta de espaços para as pessoas se encontrarem, se juntarem, se verem, espaços públicos.

Resposta- É. Até talvez, porque, vamos supor, eu participo de um grupo que todo o mês nós fazemos um almoço com uma carne diferente, um frango caipira, um peixe, uma carne assada, ou qualquer outra coisa, uma coisa exótica, codorna, fizemos a capivara.

127- Um grupo de amigos?

Resposta- É. Então tem esse grupo ali. Aí tem outro grupo que vai pescar, então no final das contas, um final de semana tu vai ali, no outro final de semana tu vai lá, então tu tem compromissos quase todo o final de semana.

128- Então vocês se organizam em grupos de amigos e já organizam o tipo de atividades de lazer...

Resposta- Sempre tem uma tarefa para o final de semana.

129- Sempre tem alguma coisa planejada. Os jovens como não têm as suas famílias, é que ficam mais soltos, mas os casados não têm essa história; modifica a vida social e a solução então é encontrar esses grupos?

Resposta- É.

130- Dizem que há muitas associações aqui, não é? 
Resposta- É associação, é amizade, é a bolada, é associação de tiro, eu não participo, mas (...).

131 - Você particularmente, não teria motivo para se organizar no sindicato, por exemplo, você gostaria de diminuir as suas horas de trabalho, sem diminuir o salário óbvio e por isso não precisaria se organizar politicamente para conseguir?

Resposta- Talvez.

132- Mas ninguém nem pensa nisso, os seus colegas comentam sobre isso?

Resposta- Até às vezes a gente conversa sobre isso, mas também tem aquele lado, se a gente vai olhar, vamos supor, eu vou diminuir o tempo de trabalho, mas eu vou ganhar a mesma coisa, para a empresa vai ser custo a mais. Eu também acabo olhando o lado da empresa.

133- Pois é, a riqueza da empresa, vocês não acham que daria conta de dar a volta para vocês também?

Resposta- Só que tem esse lado, ela dá lucro, ela distribui, em contrapartida acaba acalmando os pensamentos negativos.

134- Obviamente que aquele lucro que eles estão repartindo é insignificante em relação ao que realmente eles estão lucrando, mas ninguém sequer imagina esse montante?

Resposta- Se eu não me engano é $12 \%$.

135- $12 \%$ do lucro. O restante como eles divulgam que reinvestem na própria empresa, os colaboradores ficam realmente sem motivos para justificar uma organização política de reivindicações diferenciadas; diminuir horas de trabalho seria uma afronta. Como é que você interpretaria isso?

Resposta- Talvez sim.

136- Por exemplo, a questão que eu coloco no levantamento que eu fiz dentro da fábrica. $\mathrm{Na}$ totalidade as pessoas diziam que eles estavam muito cansados, que chegavam em casa muito cansados, produziam mais quando estavam descansados e tinham necessidade de lazer; só que não tinham tempo, nem recurso para tê-lo. Isso não seria motivo suficiente para se organizar numa reivindicação coletiva, de diminuir esse tempo de trabalho para não se cansar tanto?

Resposta- Talvez.

137- E por que talvez?

Resposta - A idéia é mais da produção, daquela produção que tira peça, põe peça. Eu já trabalho mais na manutenção, que é um trabalho diferente, vamos supor, quando a produção vai bem, a manutenção está parada e quando a produção está parada, nós estamos trabalhando. Por isso talvez, eu não vejo esse lado de estar cansado o dia todo. Tem casos que estraga uma máquina, pegou fogo no painel, vai trabalhar, sexta, sábado, domingo e segunda, vai trabalhar até (...), porque aconteceu aquilo. Agora, a produção não, a produção é programada.

138- Pois é, na produção há cansaço físico?

Resposta- Há um cansaço, ele é todo o dia.

139- E tem que produzir?

Resposta- Tem que produzir.

140- Porque tem aquela tabela do plano, não é?

Resposta- É, vem o pedido, tem que interpretar o pedido.

141- Cada sessão deve cumprir aquela quantidade de produtos naquela semana, não é assim? Eles têm que cumprir o plano de produtividade, então se não cumprir tem algum problema, 
não é? Isso é muito exaustivo, é muito cansativa essa profissão. Quer dizer, haveria uma diferença entre sessões, entre fábricas, umas são mais cansativas, outras são menos?

Resposta- Outras são menos, são mais automatizadas, tem engenharia, vamos supor, quem trabalha na fundição é terrivel, trabalhar naquele calor, poeira.

142- A fábrica "X", onde eu pesquisei mais, é fundição?

Resposta- Não, é usinagem.

143- Usinagem e rebobinagem não é?

Resposta - É, usinagem, rebobinagem e a montagem.

144- É a montagem do motor ...

Resposta- Até porque lá são motores grandes, então exige muito a coluna.

145- Fisicamente, realmente, a exigência lá é forte e por isso também há ginástica?

Resposta- Sim.

146- Porque compensa mesmo o trabalho físico. Para finalizar, qual foi o maior problema de Jaraguá do Sul que você colocou?

Resposta- Na minha opinião seria a poluição.

147- E o que tem de melhor aqui?

Resposta- Hoje em dia já não é mais tanto, mas antigamente se estacionava o carro e deixava o carro aberto. Então, não tinha tanta preocupação com ladrão, hoje em dia já não é mais assim tão fácil.

148- A tranqüilidade não é?

Resposta- Hoje tu vai para a praia, mas tu vai preocupado porque alguém pode roubar a tua casa. Antigamente não se tinha tanto essa preocupação, hoje em dia já é demais.

149- Como você justifica essa mudança?

Resposta- $O$ crescimento da cidade, muita gente de fora, vê a gente ...., vinha gente de São Paulo, assaltou aqui, veio gente de não sei onde assaltou aqui, foi pego.

150- O que o $\mathrm{Sr}$ diria sobre o maior benefício que este seu trabalho fez para você?

Resposta- Bom, eu tive a oportunidade de ir à Europa pela empresa. Eu sempre tive vontade de conhecer a terra de onde veio a minha avó, da Alemanha.

151- Você é descendente de alemão?

Resposta- Isso. Ela sempre contava histórias. E acabei tendo a oportunidade de visitar depois de vinte anos que nós não nos correspondíamos mais, eu consegui manter esse contato de novo.

152- Você viu sua avó?

Resposta- Ela morava aqui. Eu fui em 1991 para lá, eu ia em outubro e ela faleceu em abril. Mas ela contou tudo como era a cidade, onde eu tinha que pegar o trem, mais ou menos como ela lembrava que era a cidade e bem como ela falou,. hoje em dia, não muda mais tanto lá.

153- Qual a diferença da Europa para o Brasil?

Resposta- Eu acho que o Brasil é bem melhor.

154- Melhor em quê?

Resposta- A liberdade brasileira é muito grande.

155- Liberdade em quê? Por exemplo, eu achei Jaraguá do Sul bem disciplinada, e bem controlada e você acha ainda que em comparação com a Alemanha, isso aqui não é nada?

Resposta- Lá eu não vi reuniões entre amigos, reúne uma sessão e vamos fazer uma festinha ai aluga a recreativa, faz a carne, faz a festa durante a semana ou final de semana, isso de 
vez em quando acontece e lá eu não vi acontecer essas coisas, pelo menos eu não escutei falar. Escutei falar de muita gente, vamos dizer, tu vai querer queimar um monte de lixo, ou alguma coisa assim e vai para o lote do vizinho. O vizinho já liga para o departamento ambiental, já vem multa e não sei o que, é cheio das leis e autorização para fazer isso, autorização para fazer aquilo. Para mudar a casa, muitas casas são tombadas, aqui não acontece isso, se quiser construir alguma coisa, um puxadinho a mais, constrói, lá não é assim. Lá é tudo certinho, tudo na lei, o imposto é caro, bem mais do que aqui, embora lá tenha o seu benefício, saúde, aposentadoria é bem melhor, vamos dizer, eu não lembro de ter passado numa estrada de barro, é tudo asfaltado, só que há muito tempo eles trabalham com isso. A cidade de Jaraguá começou a asfaltar faz uns oito anos, bem menos do que lá no ... hoje em dia tu vai num bairro aí que antigamente era só mato, é tudo asfaltado e cheio de casa, faz pouquíssimo tempo.

156- E como é que você interpreta o que está acontecendo com as pessoas ao verem essa mudança de Jaraguá, de crescimento, de desenvolvimento?

Resposta- Acabam se isolando, até pelo, vamos dizer (....), uma cidade pequena todo mundo se conhece, todo mundo 'bom dia!', vai se cumprimentando no supermercado, Já hoje em dia, eu vou no supermercado para eu conhecer alguém é difícil, há uns quinze anos atrás, de vez em quando, batia com um conhecido, conversava e tal, hoje em dia já é bem mais difícil, cresceu muito.

157- São coisas de cidade grande, não é?

Resposta- De cidade grande.

158- E você já teve estresse?

Resposta- Eu acho que todos temos. A cobrança do trabalho, vamos supor, eu não deixo de trabalhar numa área de risco, tem o forno, se misturar com água, explode o forno, então às vezes dá algum problema, então sempre fica aquela pressão psicológica.

159- A necessidade da atenção é diária?

Resposta- É diária.

160- Eu acho que na (...), todo mundo, todos devem ficar sempre atentos?

Resposta - Tem que ficar ligado, tu trabalha com 2000 wts, ou 500 wts, então qualquer descuido... eletricidade é brabo.

161- E na fabricação dos motores também?

Resposta- Também... se engatar um dedo ou um braço, se prensa, então não dá para trabalhar distraído conversando com o vizinho.

162- É só trabalhar, oito horas de trabalho mesmo, parada só para lanchar e almoçar ?

Resposta- Não, só tem almoço, meia hora de almoço nos turnos, no horário normal é uma hora.

163- Para quem trabalha em horário normal, mas para quem trabalha em turnos seria meia hora, por que tem aquela meia hora do sábado? Só tem meia hora de almoço?

Resposta- Só tem meia hora de almoço.

164- Então, você já distribui o seu trabalho e lazer. E como é que você faz para relaxar e diminuir o estresse?

Resposta- Esporte, praia, pescaria.

165- Você diria que no caso, o lazer serve para recompor a energia do lado psicológico?

Resposta- Isso.

166- Como é que você identifica o estresse? 
Resposta- Sei lá, um nível brando, depende muito da semana, é um trabalho muito variado, essa semana não tem serviço, a semana que vem tu está como um louco, ou eles me telefonam de madrugada e me chamam.

167- E aí você tem que ir?

Resposta- Tem que ir.

168- Porque é manutenção?

Resposta- Exato.

169- E você está satisfeito com o seu salário, o que desejaria mudar?

Resposta- $O$ salário a gente sempre quer aumento, nunca está contente, o nível de vida que eu tenho, vamos supor, eu já tive oportunidade de fazer uma viagem para o Peru, para Matchuo Picho, fui duas vezes para Alemanha, embora que pela empresa, não tive gastos particulares, esporadicamente vou à Florianópolis, para o Rio Grande na casa dos parentes, então tu acaba viajando, fazendo uma coisa diferente .Quando tu vai fazer uma viagem de três, quatro dias, eu me esqueço, as 04:42H eu sou da empresa, as 14:00H eu não sou mais.

$170-$ Você consegue separar?

Resposta- Eu consigo separar.

171- Então fica satisfeito?

Resposta - Eu fico satisfeito.

172- Não trocaria essa empresa?

Resposta- Não, eu não trocaria de empresa, tem que ser um salário muito mais alto para sair. Eu já tive oportunidade de ir para São Paulo a uns dez, doze anos atrás, mas fui por esse lado, o lado da vida em Jaraguá ser muito boa.

173- Teria mais alguma coisa que você queria acrescentar sobre o trabalho ou o lazer? O que poderia existir mais de lazer aqui nessa cidade, por exemplo?

Resposta- Eu não participo, tem asa delta, eu acho que é o segundo melhor ponto do Brasil, no morro das Antenas. Trilha, eles fazem muita trilha aqui, muita gente faz, eu tenho muitos amigos que fazem.

174- É tudo prática desportiva de classe média, classe média alta, não é? Os hábitos aqui não são populares, digamos assim?

Resposta- É, talvez se você passeou pela cidade, você viu muitas quadras de futebol de areia.

175 - Eu vi muitas quadras fechadas, de alambrado, de cadeado, é por que é tudo assim mesmo, não é?

Resposta- É tudo assim mesmo.

176- E quem é que são os donos daquelas quadras?

Resposta- Geralmente é alguém da região, que eram terrenos baldios e a Prefeitura deu um ultimato de dois anos, tinha que limpar o terreno, se não limpasse, ela alugava, limpava e iria ficar alugado por uma temporada para a comunidade, então isso acabou acontecendo.

177- Está acontecendo?

Resposta- Isso foi a alguns anos, hoje em dia acabou ficando uma quadra ali, uma quadra lá, então tem muitos bairros que tem quadra, então isso junta muita gente jovem.

178- E sobre o alcoolismo da cidade? Porque as pessoas falam muito só que não tem dados, mas sabe-se que Jaraguá do Sul tem um nível muito alto de alcoolismo, você explicaria como?

Resposta- Sei lá, talvez o costume, eu tinha o meu pai em casa, ele trabalhava, saía do trabalho e ia para o boteco. 
179- Muita gente faz isso, não é?

Resposta- Muita gente faz isso, para mim pode fechar o boteco, eu não vou. Só que tem aquele lado, se juntar uma festinha, tomar uma cerveja, jogar um truco, um baralho eu acompanho.

180- Mas parece que esse é um hábito, acontece diariamente?

Resposta- Tu sai da empresa e vai para o bar com os amigos conversar.

181- Relaxar, o relaxamento é aquele?

Resposta- É aquele e daí vira nisso.

182- Vira rotina?

Resposta- Vira rotina

183- Todo mundo fala que há muitos casos aqui, como uma doença mesmo, mas aí não dá para saber mais. E me disseram que havia muito suicídio aqui?

Resposta - Suicídio, sempre dizem que alemão não pode deixar uma corda perto.

184- Tem essa tendência?

Resposta - Tem, é mais radical, mas ultimamente não tem se falado tanto.

185- Mas já ouviu falar?

Resposta- Já. Até tem esse adágio aí, alemão pôs uma corda perto porque está se enforcando.

186- Você gosta de brincar de alguma coisa?

Resposta - Eu no caso fui acostumado a jogar desde criança a jogar baralho, dominó, aos dez, doze anos aprendi a jogar xadrez e depois talvez num colégio particular, a área de esporte era muito visada, nós aprendemos a fazer ginástica olímpica, vôlei, basquete, futebol de salão, tudo que é esporte.

187- E você aprendia para brincar mesmo?

Resposta- Brincar e tinha matéria, tinha que estudar. Tinha competição, os jogos de inverno, a gente participava, tinha os jogos do colégio, tinha que participar, escola técnica, futebol de salão, basquete, vôlei, ali também tinha outro pessoal. Esse final de semana eu participo do futebol de areia do parque ... III, eu acho que são quatro, cinco finais de semana que se junta todo mundo. Então junta aquele setor, mais outro setor joga, depois acaba tomando uma cervejinha, acaba conversando.

188- Qual é a avaliação que você faz dessas brincadeiras, do esporte?

Resposta- Eu acho excelente.

189- Você gosta e é também uma coisa que relaxa?

Resposta- Inclusive aqui a minha mãe está jogando vôlei junto, ou nós vamos para a praia, ou baralho, seja lá o que for, seja lá que jogo for, a gente participa de tudo.

190- Então, muito obrigada, me desculpe qualquer coisa.

.Resposta- é as coisas ... foram se misturando aos poucos, o pensamento foi contagiando.

191- Essas perguntas foram feitas para você e outras pessoas de fora da empresa, mas as análises e as explicações das pessoas são bem parecidas com isso tudo que você está falando. Quer dizer, há idéias comuns?

Resposta- Até eu vou te dizer uma coisa, eu sempre procurei me enturmar com várias pessoas, discoteca à noite quando eu era solteiro, mas eu escutava muita gente de fora, falar; 'o pessoal de Jaraguá é fechado, não se mistura'. Mas aí eu falei para o pessoal, 'vocês às vezes não se misturam também. Vem lá cinco gaúchos, moram numa casa e ficam lá, a gente convida para uma festa, não dá, não sei o quê'. O povo daqui não, tu convida, quanto é que é, quanto é que custa, já pagam. 
192- É tudo dividido também?

Resposta - É tudo dividido, não tem que pagar sozinho, esse lado, talvez até o pessoal de fora se enturmar, acha que o pessoal de Jaraguá é fechado.

193- Há o tempo necessário para se aproximar?

Resposta- Até para os outros deixarem ...

194- Mas você vê que há essa dificuldade? Há realmente a necessidade desse tempo para depois (...), não seria tão fechado assim?

Resposta- Na minha opinião não seria.

195- Mas as pessoas não se visitam muito aqui? Já me disseram isso.

Resposta- É, pouco, mas é aquilo que eu te digo, eu vou lá com o Luís, o Carlos, o Paulo, "vamos para a praia? Vamos". Vamos para a praia, alugamos uma casa, ou vamos na casa um do outro, "ou vamos no final de semana fazer uma carne? Vamos” Fazemos lá ou faz num outro grupo, mas como aquela coisa, hoje vou visitar o fulano, sem avisar, sem nada.

196- Não existe isso aqui?

Resposta - Não, não existe.

197- É tudo planejado?

Resposta - É mais do que planejado.

198- Uma característica de tudo aqui é o planejamento. Tudo aqui é antecipado nas idéias, nada acontece sem pensar. E quando acontece um problema que exige uma solução imediata, como resolvem?

Resposta- Vamos supor, se vem uma visita inesperada lá em casa, eu compro uma carne, faço alguma coisa, atendo de braços abertos.

199- Na minha compreensão, na minha análise, essa empresa virou uma entidade que ninguém teria coragem de mexer com ela. Uma coisa misteriosa em que há o envolvimento das pessoas com essa empresa e que ninguém mexe, as pessoas defendem sempre, não é verdade?

Resposta- Vamos supor, tu vai lutar pela empresa, como se tu fosse lutar pela tua casa, porque tu sabe que ela vai te tratar bem, ela vai dar o retorno, então tu também ajuda. Então, vamos supor, porque tu vai tentar melhorar muito mais, tu acaba estragando, talvez até esse medo, faça com que a pessoa conviva com isso.

200- Porque você falou assim, as pessoas se organizam se houver necessidade, então medo do quê? Não há necessidade, então nem se pensa em sindicato, não se pensa em reivindicar nada, porque não tem o quê reivindicar, acham que está tudo certo.

Resposta- Tem o normal, tem aumento de dissídio, ou banco de horas que o sindicato fez desaprovar. Foi um ano de banco de horas, aí acabou hora extra, acabou um monte de coisa, aí no ano seguinte o sindicato foi lá, fez reuniões e acabou indo contra o banco.

201- Era prejuízo para os operários?

Resposta - Não deixa de ser porque não ganha hora extra. Vai trabalhar no sábado, aí numa segunda-feira que a tua mulher está trabalhando, tu vai ficar em casa, que graça tem isso!

202 - Então se houver uma necessidade de se organizar para reivindicar vocês se organizam a questão não é essa. A questão é que não se organizam por não sentirem necessidade ou interesse!

Resposta- $E$.

Obrigada! 


\section{ANEXO 07 \\ MANUAL DO COLABORADOR( FÁBRICA "X")}

(Obrigações e direitos do trabalhador)

Sobre o Serviço médico social. Existe ambulatório com médicos que atendem a família. A esposa, se esta não trabalhar fora e os filhos, até dezoito anos. Tem serviços complementares, exames, assistência farmacêutica: podem comprar remédios, mas é descontado na folha de pagamento.

Sobre a Assistência Odontológica. Só após completar seis meses na empresa é que o colaborador tem esse atendimento.

Sobre a Assistência Hospitalar -Existe um plano que a empresa participa com uma parte.

Sobre o Serviço social É um atendimento psicossocial aos colaboradores e dependentes.Programas:Atendimento individual familiar.Álcool/Droga; Adolescência; Relacionamento Interpessoal; Pré-Aposentadoria;

Sobre as Creches Conveniada com todas as creches da cidade, atendimento até 06 anos.

Sobre os Círculo de Integração Social -CIS As esposas dos diretores realizam trabalhos de assistência social para a família dos colaboradores

Sobre a Previdência Social Seguridade Social A empresa tem um plano de complementação dos benefícios, tanto para afastamento por auxílio doença, aposentadoria por invalidez e pensão por morte. Após um ano de empresa o colaborador é automaticamente inscrito no programa. Pode aderir também a suplementação de Aposentadoria por tempo de serviço e por idade. Desconta na folha um índice variável entre $1 \%$ a $10 \%$ dependendo o nível salarial.

Sobre os Seguros -A empresa possui apólice de seguro em grupo e Acidentes Pessoais. No plano básico o custo é da empresa. Pode ter outros planos, tais como: Seguro total de automóvel Seguro contra terceiros. Seguro residencial

Sobre o Programa de alimentação Há refeitórios próximos ao local de trabalho com baixo custo. As refeições podem ser descontadas em folha de pagamento num montante irrisório.

Sobre o Treinamento e Desenvolvimento Cursos externos e internos, a empresa tem uma área específica para isso. Na primeira semana de trabalho há treinamento para os recém admitidos para que eles se familiarizem com as atividades a desenvolver. Cada colaborador possui um cadastro de qualificação profissional que é atualizado sempre que concluir novos cursos em entidades externas.

Sobre o Auxílio Escolar A empresa suplementa valores das mensalidades escolar para os colaboradores que após um ano na empresa ingressarem nos curso técnicos em Mecânica, Elétrica, Química, Metalurgia, Eletroeletrônica, Eletromecãnica e Mecatrônica. O auxílio escolar é válido para escolas Técnicas indicadas pela Empresa. Curso superior também.

Sobre a Avaliação de Integração Após três meses de trabalho a chefia avaliará o seu desempenho, identificando os seus pontos fortes e fracos, a fim de corrigir possíveis desvios. Caso o colaborador seja efetivado poderá receber um reajuste salarial. 
Sobre a Análise de potencial Após um ano no cargo, será realizada a análise de potencial, onde, a chefia discutirá com o colaborador seus pontos fortes e fracos, traçando um plano de desenvolvimento para suprir as carências encontradas.

Sobre o CCQ-Círculo de Controle da Qualidade É um grupo formado por pessoas da mesma área que se reúnem voluntariamente para discutir assuntos referentes à qualidade, produtividade, ambiente e segurança do trabalho. Este grupo faz parte da filosofia de participação administrativa que dá liberdade para os colaboradores darem idéias a serem analisadas e, após a aprovação, serem implantadas. Quem tem interesse em participar procura o chefe para se informar. Os objetivos do grupo são: Desenvolver o potencial humano em sua plenitude. Respeito à natureza humana, criando um ambiente saudável e participativo. Contribuir para a melhoria e desenvolvimento da empresa.

Sobre a Segurança Patrimonial. Portaria e equipe de guardas em vigilância contínua. O Guarda pode examinar o conteúdo de embrulhos e pastas que estiverem em poder do colaborador, pode também submeter a uma revista pessoal. Essa medida eles afirmam que é geral e não visa ninguém em particular.

Sobre a Segurança do Trabalho- Possui uma equipe de Engenheiros, Técnicos de Segurança do Trabalho, Médicos e Enfermeiras do Trabalho, treinados para zelar pela sua segurança e saúde. Dispõe de equipamentos de proteção como: óculos, botas, luvas, avental, protetor facial, máscaras contra gases e demais equipamentos específicos em conformidade com a exigência do seu trabalho. $\mathrm{O}$ uso do equipamento de proteção é obrigatório para a segurança e saúde, se não usar é considerado uma atitude de indisciplina.

Sobre a CIPA (Comissão interna de Prevenção de acidentes) Um grupo que tem por objetivo inspecionar todos os locais de trabalho para eliminar os riscos de acidentes e de incêndios.

Sobre a Brigada de Incêndio. A empresa mantém uma brigada para prevenir e combater incêndio dentro da empresa. É formada por equipes de colaboradores treinados, tendo para isso, equipamentos próprios com extintores de incêndios, hidrantes e outros recursos.

Sobre Plano de emergência A finalidade desse plano é agir rapidamente no caso de ocorrer qualquer tipo de sinistro, como: incêndios, vendavais e enchentes (É comum nessa região enchentes e vendavais). Este socorro é prestado pelos colaboradores que residem nas proximidades da Empresa.

Sobre Equipamentos de proteção individual- EPI Há um termo de responsabilidade ao receber esse equipamento. Será considerado como ato de indisciplina a não utilização do EPI pelo empregado, podendo ser demitido por justa causa quando do não cumprimento.

Sobre Ferramentas e Equipamentos. As ferramentas, instrumentos de precisão, máquinas, equipamentos, bens materiais necessários ao desempenho da função pelo empregado serão colocados à sua disposição pela empresa, cabendo ao colaborador utilizá-lo com todo o zelo profissional.

Sobre Horário de trabalho $\mathrm{O}$ cumprimento do horário estabelecido é exigido, se sair fora do horário é preciso comunicar ao chefe. Pode ser alterado conforme as necessidades inclusive para prestação de serviços extras. 
Sobre Registro de ponto $\mathrm{O}$ ponto só pode ser registrado pelo próprio colaborador até 15 minutos antes do horário de entrada e no máximo 10 minutos após o horário de saída. Em caso de erro, procura-se o chefe.

Sobre Faltas/Chegadas tardias Se não forem justificadas será passível de punição. Se ultrapassar a duas horas na semana em chegadas tardias, saídas antecipadas e ausência durante a jornada, será perdido o direito ao repouso remunerado.

Sobre Horas extraordinárias. As horas que forem trabalhadas além da jornada normal são pagas da seguinte forma: $50 \%$ sobre a hora normal, qdo efetuadas em dia normal de trabalho ( $2^{\mathrm{a}}$ a Sábado),100\% sobre a hora normal, para as horas extraordinárias ou realizadas nos domingos e feriados. Quando a hora extra ocorrer entre às $22 \mathrm{~h}$ e $5 \mathrm{~h}$ incidirá o adicional noturno. As reuniões dos grupos da empresa devem acontecer no horário de trabalho, se acontecer fora não será pago hora extra.

Sobre Ausências justificadas, todas garantidas por lei, e viagem de estudodispensa, mas, desconta. Enchente/vendaval- ou recupera, ou tem desconto sem perder o Domingo remunerado. Atraso de ônibus- ou desconta ou será recuperado.

Sobre Auxílio doença. Afastamento por enfermidade. Afastamento por acidente de trabalho. Afastamento por auxílio maternidade.

Sobre Ambiente de trabalho. A empresa preza por um ambiente de trabalho em que esteja limpo, organizado, saudável, seguro e com disciplina. Funciona aqui a filosofia Japonesa chamada de 5S. São cinco palavras de origem Japonesa, que traduzidas significam: $1^{\circ} \mathrm{S}$ - SEIRI - utilização (O que a gente não precisa, só atrapalha), $2^{\circ} \mathrm{S}$ - SEITON - Ordenação ( Se está no lugar está na mão); $3^{\circ} \mathrm{S}$ - SEISO Limpeza (Setor limpo é aquele que menos suja), $4^{\circ} \mathrm{S}$ - SEIKETU- Saúde ( Um lugar limpo e organizado é mais seguro e mais saudável), $5^{\circ}$ S- SHITSUKE - Autodisciplina ( É a atitude de por em prática todos os itens acima descrito).Todos devem comparecer ao serviço em boas condições de higiene e asseio individual. E lembram que a Empresa onde você trabalha é uma extensão de sua casa, mantê-la limpa e organizada é a melhor forma de se obter segurança e saúde.

Sobre a Associação Recreativa. É aberta a todos os colaboradores e aos seus familiares. Possui Parques, lanchonetes, restaurante, sala de jogos, e churrasqueira. Modalidades de Esportes: bolão, futebol de campo, f. de salão, f. suíço, handebol, basquete, vôlei, bocha, tênis de mesa, xadrez, dominó, canastra, caneco, atletismo, entre outras. A empresa promove vários campeonatos. Participa dos torneios esportivos da cidade e no estado. Festas, gincanas, bailes e outros são feitas para criar a oportunidade ditas de Lazer e entrosamento entre os colaboradores.

Sobre a Disciplina A disciplina consiste no cumprimento das normas, ordens, e deveres. O não cumprimento é passível de punição que poderá ser: Advertência verbal, Advertência escrita, Suspensão, Demissão. A punição será aplicada segundo a gravidade da falta cometida, não precisando respeitar necessariamente a seqüência acima.

Sobre a Distribuição de Lucros, desde 1991 que a empresa possui o P ...QP (Programa (Nome da empresa) de Qualidade e Produtividade). Se a empresa obtiver lucros cada um dos seus colaboradores recebe uma fatia desse bolo. 


\title{
ANEXO 08
}

\section{EVENTOS NO ANO DE 2001}

\author{
MARÇO
}

De 8 a 30 - CIRCUITO NACIONAL DE ARTES PLÁSTICAS

De 17 de março a 8 de abril - FEIRA DE PÁSCOA

Dia 22 - DIA MUNDIAL DA ÁGUA

Dias 22 e 24 - COMEMORAÇÃO DO DIA INTERNACIONAL DA ÁGUA

Dia 25 - SHOW 125

Dia 30 - JANTAR MENSAL

Dias 31 de março e 01 de abril - TORNEIO DE TIRO

ABRIL

II PÁSCOA COM A TERCEIRA IDADE

De 2 a 8 - "MOLEQUE BOM DE BOLA"

Dias 6, 7 e 8 - FEIRA AUTOMOTIVA

7, 10, 11 e 12 - PESCA DO BALAIO

Dia 7 - DIA MUNDIAL DA SAÚDE

Dia 7 - CAFÉ COLONIAL

Dias 7 e 8 - TORNEIO DE TIRO

De 9 a 30 - CIRCUITO CATARINENSE DE ARTES PLÁSTICAS

Dia 11 - DIA DA SAÚDE

Dia 14 - BAILE DE PÁSCOA

Dia 19 - DIA DO ÍNDIO

Dia 20 - WORKSHOP PROJETO PALCO GIRATÓRIO

Dia 21 - CIRCUITO NACIONAL SESC DE TEATRO E DANÇA

Dia 21 - BAILE DE REI E RAINHA

Dias 21 e $22-2^{\text {a }}$ ETAPA DO CAMPEONATO CATARINENSE DE PARAPENTE

Dia 22 - DIA DO PLANETA TERRA

Dia 22 - SHOW 125

Dia 27 - JANTAR MENSAL

Dia 28 - BAILE DE REI E RAINHA

Dia 28 - FESTA DO TRABALHADOR

Dia 28 - BAILE DE ANIVERSÁRIO

Dias 28 e 29 - GINCANA 24 HORAS

MAIO

I CURSO DE CAPACITAÇÃO PARA VOLUNTÁRIOS DA TERCEIRA IDADE ABERTURA DOS JOGOS INTEGRATIVOS DA TERCEIRA IDADE

Dia 1 - FERIADO NACIONAL - DIA DO TRABALHADOR

De 2 a 5 - SEMANA DE TECNOLOGIA

Dia 3 - DIA DO SOL

Dia 5 - BAILE DE RAINHA

De 7 a 31 - CIRCUITO CATARINENSE DE ARTES PLÁSTICAS

Dia 9 - DIA DA SAÚDE

Dia 10 - HOMENAGEM AO DIA DAS MÃES - MENINAS CANTORAS DE PETRÓPOLIS

Dia 11 - FESTIVAL ESTUDANTIL DA CANÇÃO

Dia 12 - BAILE DE ANIVERSÁRIO E GAROTA VIEIRENSE

Dia 12 - INTER ESCOLAR JARAGUÁ $2^{\circ}$ ETAPA

Dias 12 e $13-13^{\text {a }}$ WINTERFEST

De 14 a 18 - SEMANA DA COMUNICAÇÃO E LINGUAGEM 
De 15 a 19 - FEIRA DE LIVROS INFANTIS

Dia 18 - ENCONTRO FESTIVO

Dia 19 - BAILE DE REI

Dia 19 - BAILE DE REI E RAINHA

Dia 19 - BAILE DE RAINHA

Dia 20 - ENCONTRO ARTÍSTICO E CULTURAL

Dia 20 - FESTIVAL DE ALEGORIAS

Dia 25 - DIA DO TRABALHADOR RURAL

Dia 25 - JANTAR MENSAL

Dia 26 - BAILE DE REI

Dia 26 - $4^{\mathrm{a}}$ INSPEÇÃO TÉCNICA VEICULAR

Dia 27 - SHOW 125

SONORA BRASIL - CIRCUITO NACIONAL SESC DE MÚSICA

Dia 30 - DIA DO DESAFIO - CHALLENGE DAY

Dia 31 - DIA MUNDIAL DE COMBATE AO FUMO

JULHO

Dia 2 - DIA NACIONAL DO BOMBEIRO

De 2 a 31 - EXPOSIÇÃO DE ARTISTAS PLÁSTICOS LOCAIS

De 6 a 15 - JOGOS ESCOLARES DE INVERNO

Dias 6, 7 e 8 - KOLONESTENFEST

Dia 7 - FESTA JULINA

Dia 7 - SÁBADO LEGAL

Dia 7 - ESCOLHA DA RAINHA

Dia 7 - BAILE DE REI

Dia 11 - DIA DA SAÚDE

Dia 14 - BUNTER ABEND / NOITE CULTURAL

Dia 14 - BAILE DE RAINHA

Dias 14 e 15 - FESTA DO COLONO

De 14 a 28 - FEIRA DA MALHA DO PORTAL

De 16 a 21 - BRINCANDO NAS FÉRIAS

De 18 a $21-1^{a}$ JORNADA SESC DE CULTURA E EDUCAÇÃO

Dia $21-1^{\text {a }}$ ETAPA DO CAMPEONATO CATARINENSE DE VELOCIDADE

Dias 21 e $22-17^{\mathrm{a}}$ KOLONISTENFEST

Dia 22 - CORRIDA RÚSTICA

Dia 25 - DIA DO COLONO

Dia 25 - FERIADO MUNICIPAL - ANIVERSÁRIO DE 125 DE JARAGUÁ DO SUL

Dia 25 - FESTIVAL INTERNO DE VÔO LIVRE

Dia 25 - SHOW DE ANIVERSÁRIO

Dia 27 - JANTAR MENSAL

Dia 28 - BAILE DO ATIRADOR

SONORA BRASIL - CIRCUITO NACIONAL SESC DE MÚSICA

AGOSTO

CAMINHADA ECOLÓGICA

De 1 a 31 - EXPOSIÇÃO DE ARTISTA PLÁSTICO LOCAL

Dia 4 - BAILE DE REI

Dias 4 e $5-6^{a}$ FEST DER LICHTFLUSCHÜTZEN

Dia 5 - DIA NACIONAL DA SAÚDE

Dia 6 - IV SESSÃO DE PÔSTERES DO CURSO DE PEDAGOGIA

Dias 9 e 10 - CONCURSO DE DECLAMAÇÃO

De 9 a 11 - FEIRA DO LIVRO e ENCONTRO DOS POETAS

De 9 a $29-1^{\circ}$ CONCURSO SESC DE FOTOGRAFIA PROFISSIONAL

Dias 10 e $11-11^{\circ}$ JEEP RAID 
Dia 11 - ENCONTRO DE CORAIS

Dia 11 - BAILE DE REI

Dia 11 - BAILE DE REI

Dia 11 - BAILE DE REI E RAINHA

Dia 11 - BAILE DE REI E RAINHA DO TIRO, BOCHA E BOLÃO

De 13 a 29 - INSCRIÇÕES SAEM - SISTEMA DE AVALIAÇÃO DO ENSINO MÉDIO

Dia 15 - DIA DA SAÚDE

Dia 18 - BAILE DE REI E ANIVERSÁRIO

Dia 18 - XV ENCONTRO CANOA ECOLÓGICA

Dias 18 e 19 - TORNEIO DE TIRO

Dias 18 e 19 - $6^{\mathrm{a}}$ FREUNDSCHAFTFEST

Dia 18 e 19 - FEIRA DE PONTA DE ESTOQUE

Dia 19 - DIA DE INTEGRAÇÃO E TARDE CULTURAL

Dias 24 e 25 de agosto - II FESTA DAS ETNIAS

Dia 25 - BAILE DE REI

SETEMBRO

TORNEIO DE INCENTIVO CURIÓ

Dia 1 - BAILE DE REI E RAINHA

Dia 1 - $4^{\circ}$ BAILE ASSOCIAÇÃO MORADORES RIO DA LUZ - escolha garoto e garota AMBRILUZ

De 1 a 27 - EXPOSIÇÃO DE ARTESANATO $3^{\mathrm{a}}$ IDADE

Dia 2 - FESTA DO TIRO

Dia 3 - SESSÃO CÍVICA DE ABERTURA DA SEMANA DA PÁTRIA

Dia 7 - FERIADO NACIONAL - INDEPENDÊNCIA DO BRASIL DESFILE CÍVICO

De 7 a 9 - $10^{\circ}$ ENCONTRO SUL BRASILEIRO DE MOTOCICLISMO

Dia 8 - BAILE DE REI

Dia 8 - BAILE DE RAINHA

De 11 a 13 - SEMANA DE ADMINISTRAÇÃO

Dia 12 - DIA DA SAÚDE

Dia 13 - SESC E VOCÊ - 55 ANOS

Dia 15 - PESCA DO BALAIO

Dia 15 - BAILE DE REI E RAINHA

Dia 15 - BAILE DE RAINHA

Dia 15 - BAILE DE REI

Dia 15 - FESTIVAL DA CANÇÃO

De 17 a 21 - SEMANA DE ESTUDOS JURÍDICOS

De 20 a 23 - $7^{\circ}$ JARAGUÁ EM DANÇA

Dia 21 - DIA DA ÁRVORE

Dia 22 - BAILE DE REI

Dia 21 de setembro - ENCONTRO FESTIVO

Dia 22 - BAILE DE REI

Dia 22 - ESTADUAL $5^{\text {a }}$ ETAPA DE BICICROSS

De 24 a 28 - SEMANA DE CIÊNCIAS CONTÁBEIS

De 24 a 28 - PROJETO DRAMATURGIA: LEITURA EM CENA

Dia 27 - COMEMORAÇÃO DO DIA NACIONAL DO IDOSO

Dia 28 - PREMIAÇÃO $1^{\circ}$ CONCURSO SESC DE FOTOGRAFIA PROFISSIONAL

Dia 28 - JANTAR MENSAL

Dia 29 - BAILE DE RAINHA

Dia 29 - BAILE DE RAINHA

Dia 29 - $3^{\text {a }}$ ETAPA DO CAMPEONATO CATARINENSE DE DESCIDA

Dia 29 - SESC E VOCÊ - III IDADE EM FOCO

Dia 30 - FESTA DA $3^{\text {a }}$ IDADE

SONORA BRASIL - CIRCUITO NACIONAL SESC DE MÚSICA

CONCERTOS SESC - O MELHOR DA MÚSICA POPULAR BRASILEIRA 


\section{OUTUBRO}

INÍCIO DO III CURSO DE DANÇAS DE SALÃO PARA A TERCEIRA IDADE PROJETO "AVÔ SABE"

Dia 2 - DIA INTERNACIONAL DO IDOSO

Dias 5, 6 e 7 - SUL AMERICANO DE BICICROSS

De 7 a 31 - CIRCUITO CATARINENSE DE ARTES PLÁSTICAS

De 8 a 13 - MOSTRA ÁLBUM DE FAMÍLIA - SESC SAÚDE

Dia 10 - DIA DA SAÚDE

De 11 a 21 - XIII SCHÜTZENFEST

Dia 12 - FESTA DA CRIANÇA

Dia 12 - SESC E VOCÊ - BRINCADEIRAS DE CRIANÇAS

Dia 15 - DIA DO PROFESSOR

De 19 a 21 - III RODEIO CRIOULO NACIONAL

Dia 20 de outubro - CAFÉ COLONIAL

Dia 20 - BAILE DE REI E RAINHA

Dia 21 - INTER ESCOLAR JARAGUÁ $3^{\text {a }}$ ETAPA DE BICICROSS

De 24 a 26 - INTEGRAÇÃO DE TEATRO (INTEJS)

Dia 27 - BAILE DE REI

Dia 27 - MINIMARATONA DO SESC

Dia 27 - BAILE DE REI E RAINHA

De 29 a 31 - IV JORNADA DE EDUCAÇÃO

De 29 a 1/11 - SEMANA DE ARQUITETURA E URBANISMO

Dia 31 - FESTA DAS BRUXAS

PROJETO PALCO GIRATÓRIO

NOVEMBRO

I GINCATI (Oficina do Corpo)

II CURSO DE CAPACITAÇÃO PARA VOLUNTÁRIOS DA TERCEIRA IDADE

$2^{\circ}$ ACAMPAMENTO

De 1 a 30 - MOSTRA FOTOGRÁFICA "Mulher ao pé da letra"

Dia 3 - ESTADUAL 6 ${ }^{a}$ ETAPA DE BICICROSS - FINAL

Dia 3 - BAILE DE RAINHA

Dias 3 e 4 - FESTIVAL DE ALEGORIAS

Dia 10 - BAILE DE RAINHA

Dia 10 - SÁBADO LEGAL

Dia 10 - BAILE DE REI

Dia 11 - ALMOÇO DAS NAÇÕES

Dia 14- DIA DA SAÚDE

De 15 a 18- 3a EDIÇÃO "ECO RADICAL"

Dia 17 - BAILE DE REI E RAINHA

Dia 17 - BAILE DE REI

Dia 17 - BAILE DE REI E RAINHA

Dia 17 - BAILE PÚBLICO

Dia 18 - MITGLIEDFEST

Dias 24 e 25 - TORNEIO CARABINA MASCULINO INTERMUNICIPAL

Dias 24 e 25 - $5^{\text {a }}$ ETAPA DO CAMPEONATO CATARINENSE DE PARAPENTE

De 24 de novembro a 16 de dezembro - FEIRA DE NATAL

Dia 24 - BAILE DE ANIVERSÁRIO

Dia 24 - BAILE DE RAINHA

Dia 30 - JANTAR DANÇANTE - ANIVERSÁRIO 10 ANOS

SONORA BRASIL - CIRCUITO NACIONAL SESC DE MÚSICA ORIGENS GUERREIROS E TORÉS 
DEZEMBRO

ENCERRAMENTO DAS ATIVIDADES DAS OFICINAS EM 2001 E DE FINAL DE ANO ENTRE OS IDOSOS AUTO DE NATAL

De 1 a 21 - MOSTRA LITERÁRIA JOSÉ SARAMAGO

Dia 1 - BAILE DE ENCERRAMENTO

Dia 1 - BAILE DE REI E RAINHA

Dia 1 - BAILE DE REI

Dia 8 - BAILE DE REI E RAINHA

Dia 12 - DIA DA SAÚDE

Dias 15 e 16 - $2^{\text {a }}$ SOMMERFEST

Dias 15 e 16 - CONCERTO DE NATAL

Dia 25 - BAILE DE NATAL

Dia 25 - BAILE PÚBLICO

Dia 25 - BAILE DE NATAL

Dia 25 - BAILE DE NATAL

Dia 25 - BAILE DE NATAL

Dia 31 - BAILE DE SÃO SILVESTRE

Dia 31 - BAILE DE SÃO SILVESTRE

Dia 31 - BAILE DE ANO NOVO

Dia 31 - BAILE DE RAINHA

Dia 31 - BAILE DE REI

EVENTOS PERIÓDICOS

EXPOSIÇÃO DE ARTES NA PRAÇA

GRUPO DE ATUALIZAÇÃO DA TERCEIRA IDADE

GRUPO DE GESTANTES

GRUPO DE ADOLESCENTES

DIA DA SAÚDE NA EMPRESA

$5^{\text {a }}$ ETAPA COPA MALWEE DE BICICROSS

CAMPEONATO ESCOLAR "PROJETO FUTURO"

$3^{\circ}$ ENCONTRO DE CORAIS

VII NOITE MARES DO SUL

ETAPA CATARINENSE DE AUTOMOBILISMO

FESTA DA PORCHETTA

FESTIVAL DE ALEGORIA E ETAPA DO CAMPEONATO CATARINENSE DE PARAGLIDES

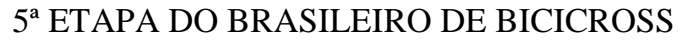

III FEIRA DE NATAL

ECO RADICAL 4 E $5^{\circ}$ FESTIVAL DE BANDAS BICHO GRILO

MITGLIEDFESF

JOGOS DE ENCERRAMENTO 


\section{ANEXO 09 \\ MODELO DO QUESTIONÁRIO APLICADO AO GRUPO DE TRABALHADORES NO CHÃO DA FÁBRICA X}

Este é um dos instrumentos de coleta de dados utilizados para uma pesquisa cujo objetivo principal é analisar as repercussões das Novas tecnologias no Tempo Livre /Lazer do Trabalhador. Não será necessário escrever seu nome, as suas respostas são anônimas.

Parte I - Informações Pessoais

A- Qual o seu sexo? ( ) Masculino ( ) Feminino

B- Qual a sua idade? ....... anos

C- Qual o seu estado civil? ( ) solteiro ( ) casado / vivendo com parceiro

( ) viúvo ( ) divorciado / separado

D- Quantas pessoas moram em sua casa? pessoas

E- Sua casa é própria, de parentes ou alugada?

F- Se tem filhos, quantos ? ....... filhos(as)

G- Se você estudou, até que série completou seus estudos?

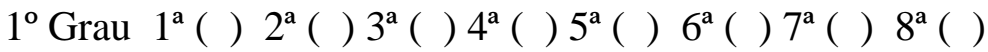

$2^{\circ}$ Grau $1^{\text {a }}\left(\right.$ ) $2^{\text {a }}\left(\right.$ ) $3^{\text {a }}($ )

$3^{\circ}$ Grau completo ( ) Qual a Faculdade?

incompleto ( ) Por que parou?

G- Você têm em casa :

TV em cores ( )

Máquina de lavar ( )

Rádio

Aspirador de pó

( ) Geladeira

( )

Vídeocassete

( ) Empregada mensalista ( )

Automóvel

( ) Freezer 
Parte II - As respostas a estas perguntas são bem importantes, por favor, não deixe de responder.

1.Você pratica alguma atividade física fora do seu trabalho?

Se for algum esporte, qual?.

Outro tipo de atividade, qual?.

Teria alguma atividade que gostaria de praticar, mas não consegue por algum motivo?

Qual seria?...

Por que não consegue?.

2. Você sente-se estressado de alguma maneira?

Como você percebe que está estressado?...

O que mais provoca estresse em você?

3.Depois que você começou a fazer ginástica na empresa percebeu algum tipo de diferença em você? Qual seria?.

O que mais modificou em sua vida familiar depois da prática dessa ginástica?.....

E com os colegas o que é que está diferente?

4.Como você se desloca para chegar ao trabalho?

Bicicleta ( ) Ônibus ( ) Automóvel ( ) A pé ( ) De carona ( )

Quanto tempo costuma gastar?

5.Você tem tempo para realizar atividades de Lazer?.

Quantas horas por semana?.

Sente necessidade de Lazer?.

Qual a atividade que mais gosta de realizar no tempo de Lazer?

Qual é a atividade de Lazer que você faz todo os dias?

Qual é a maior dificuldade para você ter e realizar atividades de Lazer?

6. Diga com suas palavras o que é Lazer para você?

7. Quantas horas você trabalha por semana? 40 horas ( ) Mais de 40 ( ) Menos de 40 ( ). 


\begin{abstract}
ANEXO 10
ROTEIRO DA ENTREVISTA - QUESTÕES PRINCIPAIS

$1 \mathrm{O}$ que você gosta mais de fazer como atividade de Lazer?

$2 \mathrm{O}$ que você faz em seu dia como atividade de Lazer?

3 O que você gosta mais em seu corpo?

4 Quando é que você fica com mais disposição para trabalhar, bastante?

5 Você tem tempo para o Lazer?

6 Você separa dinheiro do salário para gastar no Lazer?

$7 \mathrm{O}$ que mais lhe diverte e lhe dá satisfação? Por quê?

8 O que é Lazer para você?
\end{abstract}

